\title{
A dDAAM sejtvázszabályozó fehérje szinaptikus fejlődésben betöltött szerepének vizsgálata
}

\author{
Ph.D. értekezés
}

Készítette: Migh Ede

Témavezető: Dr. Mihály József

Magyar Tudományos Akadémia

Szegedi Biológiai Kutatóközpont

Genetikai Intézet

SZTE TTIK

Biológia Doktori Iskola

Szeged, 2018. 


\section{TARTALOMJEGYZÉK}

A sejtváz általános felépítése és müködése.........................................................4

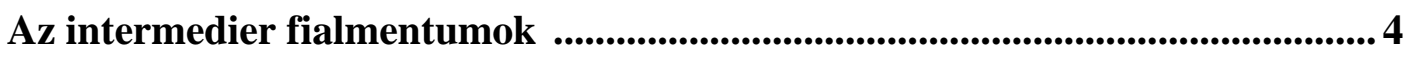

Az aktin sejtváz szerveződése és müködése $\quad$....................................................5

Aktinkötö fehérjék .................................................................................6

Aktin nukeláló faktorok............................................................ 7

Az Arp2/3 komplex felépitése és müködése ................................... 8

Tandem WH2 nukleátorok felépitése és müködése ......................... 9

Leiomodin-szerü nukleációs faktorok.......................................... 11

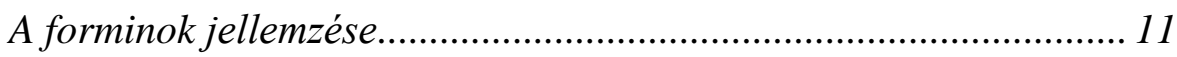

A mikrotubulusok általános jellemzése ............................................................... 15

A mikrotubulus nukleáció ........................................................................... 16

A mikrotubulus dinamika szabályozása

Mikrotubuluskötö + TIP fehérjék ........................................................ 17

Strukturális mikrotubulus asszociált fehérjék ......................................... 20

A forminok és a mikrotubulusok ......................................................... 21

A DAAM formin alcsalád jellemzése és kapcsolata a Wnt jelátviteli utakkal .. 22

A kémiai szinapszisok általános felépítése és müködése ............................................... 24

A Drosophila NMJ, mint szinaptikus modellrendszer..............................................25

Az embrionális Drosophila NMJ kialakulása és fejlödése ................................... 25

A lárvális Drosophila NMJ fejlödése ................................................................. 28

Az aktin sejtváz szerepe és szabályozása a szinaptikus fejlődés során............... 31

A mikrotubulusok szerepe és szabályozása a szinapszisok kialakulásában ...... 34 
A dDAAM kölcsönható partnereinek azonosítása központi idegrendszerből 38

A dDAAM fehérje szerepének vizsgálata az embrionális szinapszisképződésben.. 41 A dDAAM fehérje szükéges a lárvális NMJ képződésben 43

A dDAAM a preszinaptikus mikrotubulus stabilizálódás pozitív szabályozó

faktora 49

A konstitutívan aktív C-DAAM elősegíti az új boutonok kialakulását 54

A dDAAM a Dlar/Trio/Dia jelátviteli egységtől függetlenül szabályozza

a szinaptikus bouton képződést .56

A $d D A A M$ domináns genetikai interakciót mutat a $w g$ és az Ank2 génekkel ...........59

A dDAAM az Ank2-XL fehérjével együtt szabályozza a preszinaptikus mikrotubulus köteg organizációját 61

A dDAAM együttmüködik a preszinaptikus Wg szignalizáció egyik sejtváz effektor fehérjéjével a Futsch-csal.

A dDAAM Brp függő jelenléte moduláris funkcióval bír a szinaptikus transzmisszióban .65

EREDMÉNYEK MEGVITATÁSA 75

ANYAGOK ÉS MÓDSZEREK 81

FONTOSABB RÖVIDÍTÉSEK 88

KÖSZÖNETNYILVÁNÍTÁS 90

ÖSSZEFOGLALÁS 92

SUMMARY 96

IRODALOMJEGYZÉK 100 


\section{A sejtváz általános felépítése és müködése}

Jelenlegi tudásunk szerint az összes élő sejt a Földön rendelkezik sejtvázzal. A sejtváz, mint elnevezés egy merev és egyszerű struktúrára utal, pedig a valóságban egy dinamikus, bonyolult rendszerről van szó, ami lehetővé teszi, hogy számos funkciót lásson el a sejtben. Ilyen funkció lehet a sejtmozgás, a sejtalak fenntartás, az intracelluláris transzport, az organelláris transzport, illetve a sejtosztódás. Az eukarióta sejtváz 3 fö szerkezeti egységből épül fel: az intermedier filamentumokból, a mikrotubulusokból, illetve a mikrofilamentumokból vagyis az aktin sejtvázból.

\section{Az intermedier filamentumok}

Az intermedier elnevezés abból a megfigyelésből származik, hogy a $10 \mathrm{~nm}$ átmérőjü intermedier filamentum az izomsejtekben lévő aktin filamentumnál vastagabb, viszont a miozin filamentumnál keskenyebb szerkezeti elem. Az intermedier filamentumok felépítésüket tekintve homo-, vagy heteropolimerek lehetnek, amelyek az aktin filamentumoknál, illetve a mikrotubulusoknál intaktabb, kevésbé dinamikusan változó struktúrák, ezáltal a funkciójuk leginkább a sejtek szerkezeti integritásának a megőrzése. A humán genomban 67 intermedier filamentum gén található, ami az intermedier filamentumok rendkívüli sokszínűségére utal. Számos intermedier filamentum létezik, amelyeket aminosav szekvencia homológia és fehérje szerkezet alapján 6 különböző csoportba lehet sorolni.

Az I., és II. csoportba a savas, illetve bázikus keratinok tartoznak, amelyek leginkább epiteliális sejtekben találhatóak meg. A keratin egy olyan heteropolimer lánc, amely savas és bázikus keratin monomerekből épül fel. A III. csoportba négyféle fehérje tartozik. Ezek közül a leggyakrabban előforduló fehérje a vimentin, amely megtalálható a fibroblasztokban, a leukocitákban, illetve az erek endotél sejtjeiben is. A csoport következő fontos képviselője a dezmin, amely az izmokban található szarkomerek egyik fontos strukturális eleme. A harmadik tagja a csoportnak a GFAP (glial fibrillar acidic protein) legföképpen a gliasejtekben és az asztrocitákban fordul elö, míg végül a peripherin, amit a neve is jelez, a perifériás idegrendszer idegsejtjeire jellemző. A IV. csoportot a neurofilamentumok (NF) képviselik. Specifikusan a központi idegrendszer (KIR) neuronjainak axonjaiban fordulnak elő, ahol a mikrofilamentumok és a mikrotubulusok mellett fontos eleme a neuronális citoszkeletonnak.

$\mathrm{Az}$ V. csoportot a laminok alkotják, amelyek a sejtmagban találhatóak ellentétben a többi intermedier filamentummal, amelyek citoszolikusak. Az utolsó VI. csoportba a nestinek 
tartoznak, amelyek 230kDa méretü fehérjék és homopolimereket hoznak létre. Főleg izomsejtekben, és embrionális neuronokban fordulnak elő.

\section{Az aktin sejtváz szerveződése és müködése}

Az aktin sejtváz egy rendkívül dinamikusan változó, flexibilis és plasztikus rendszer, amelynek elsődleges funkciója, hogy mechanikai erőket generálva sejtalak változást hozzon létre. A sejtalak változás mellett, ami elsődlegesen a kortikális membránt érinti, az aktin sejtváz által kifejtett erők képesek intracelluláris membránok, organellumok és vezikulák helyzetét, illetve alakját is befolyásolni. Ily módon a sejtben számos funkciót lát el, mint például: sejtmozgás, sejtdifferenciáció, sejtosztódás és számos transzportfolyamat. Mivel az aktin sejtváznak ilyen sokrétű funkciói vannak, ezért számos aktinkötő, illetve motorfehérjére van szükség a sejtekben, ahhoz hogy térben és időben ezek a funkciók megfelelően elváljanak.

Az aktin egy 42 kDa nagyságú, nagyfokú evolúciós konzerváltságot mutató, az eukarióta sejtek egyik legnagyobb mennyiségben jelenlévő fehérjéje. Az „actin” elnevezés Straub F. Brúnó nevéhez kapcsolódik, aki Szent-Györgyi Albert laboratóriumában először izolálta az aktint izomsejtekből, amit korábban már ismertek ebben a laboratóriumban a miozin viszkózusabb formájaként és aktivált miozinnak hívtak, amiből az elnevezés is származtatható.

Az aktin a sejtekben kétféle formából áll, globuláris aktin monomerekből (G-aktin) és filamentáris aktin polimerekből (F-aktin). Az élő sejtekben az aktin nagyjából fele globuláris formában, míg a másik fele polimer formában található meg. Az aktin filamentumok 6-7 nm átmérőjü, kettős helikális struktúrák, amelyben a láncok csavarulatai 37 nm-es távolságonként ismétlődnek [1]. A filamentumban a két párhuzamos lefutású G aktinból álló lánc úgy tekeredik egymásra, hogy bennük a monomerek egymáshoz képest fej farok orientációban helyezkednek el. 
A

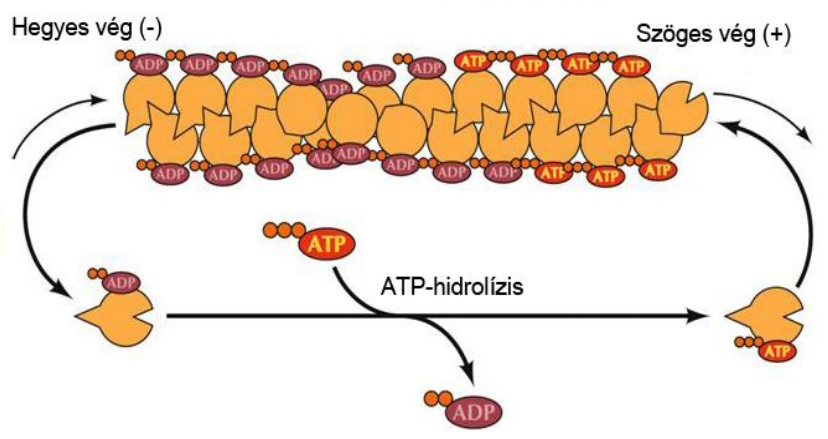

B

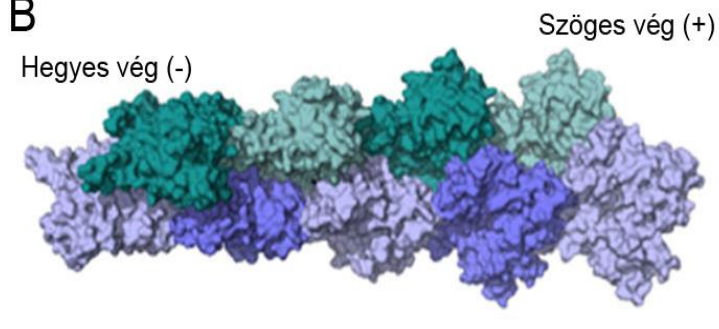

1. ábra Az aktin filamentum szerkezete. (A) A sematikus filamentum modell szemlélteti, hogy in vivo a szöges végen ATP-aktin beépülés történhet, ami az aktin saját ATPáz aktivitása miatt ADP-aktinná alakul. A hegyes vég a depolimerizáció helye, a disszociáló ADP-aktin monomerek ATP jelenlétében pedig újra ATP-aktinná alakulhatnak. (B) Az F-aktin oligomer kettős helikális struktúrájának térbeli szerkezete, amely rendelkezik a gyorsan növő szöges és a lassan növő hegyes véggel. Az ábra a www.slideshare.net webhelyről letöltve és módosítva.

Az aktin filamentumok nemcsak struktúrális, hanem kinetikai polaritással is rendelkeznek. Ennek alapja az, hogy a filamentumba a G-aktin ATP-vel alkotott komplexe képes csak beépülni, viszont az aktin monomerek ATP-áz aktivitást mutatnak, amelynek mértéke jelentősen megemelkedik a filamentumba épülést követően. Az ATP hidrolízise után a filamentumban képződő ADP-aktin viszont olyan konformáció változást okoz, ami a filamentumot instabillá teszi, így növelve a depolimerizációra való hajlamot. In vitro körülmények között ezek a tulajdonságok azt eredményezik, hogy a képződő filamentumok mindkét végén történhet monomer beépülés és kilépés is, viszont ezeknek sebessége a két végen jelentősen eltérő (1. ábra). A filamentum ún. szöges $(+)$ végén, ahol az ATP-aktin a prominens kb. 10-szer gyorsabb a beépülés sebessége, mint az ún. hegyes (-) végen amire az ADP-aktin jelenléte a jellemző (1. ábra). Ez a különbség in vivo körülmények között még nyilvánvalóbb, ott ugyanis a polimerizáció kizárólag csak a szöges végen történhet, míg a hegyes végen az aktin monomerek kilépése, depolimerizációja megy végbe.

\section{Aktinkötő fehérjék}

A mikrofilamentumok alapvetően kétféle magasabb szerveződési szinttel rendelkező aktin struktúrát hozhatnak létre a sejtekben. Ezek közül az egyik az el nem ágazó, párhuzamos lefutású aktin kötegek, míg a másik a bonyolult, szövevényes, elágazó aktin hálózatok. A magasabb szerveződési szintü aktin struktúrák kialakulásához, amelyek számos folyamatban vesznek részt (sejtvándorlás, sejtosztódás stb.) elemi szükség van arra, hogy rendkívül rigorózus módon szabályozza a sejt ezen struktúrák képződését, illetve lebontását térben és 
időben egyaránt. Ennek eredményképpen számos aktinkötő fehérje ismert, amelyek kapcsolódásuk és funkciójuk alapján különféle csoportba sorolhatóak. Kapcsolódásuk alapján lehetnek monomer kötők, illetve a filamentumhoz kötődők, amelyek képesek lehetnek a filamentum oldalához vagy végeihez kötődni. Aktivitásuk alapján megkülönböztethetünk nukleációt elősegítő, polimerizációt elősegítő, polimerizációt gátló, depolimerizációt elősegítő, fragmentációt elősegítő, filamentumot stabilizáló, filamentumokat keresztkötő gél- és kötegformaló fehérjéket valamint motorfehérjéket [2, $\underline{3}]$.

\section{Aktin nukleáló faktorok}

Az aktin sejtvázszabályozás egyik rendkívül fontos eleme a de novo filamentum képződés, ami spontán módon kinetikai okok miatt a sejtben nem támogatott [4-6].

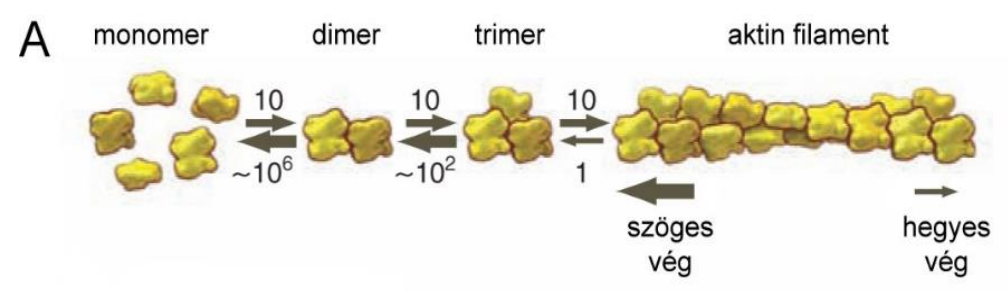

B

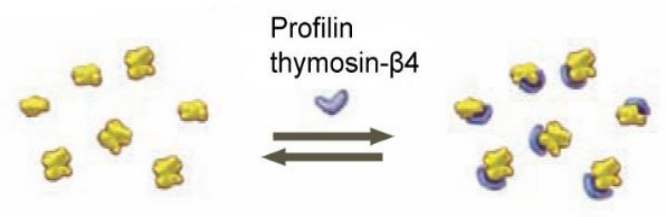

2. ábra Spontán nukleáció és elongáció sematikus modelljei. (A) Az aktin dimerek és trimerek instabilak in vivo körülmények között. A hosszabb polimerek a szöges vég felöl gyorsabban nőnek, mint a hegyes vég felöl.

(B) A monomer kötő Profilin és a thymosin- $\beta 4$ megakadályozza a véletlenszerü nukleációs magok létrejöttét. Az ábra a [7]-es publikáció alapján módosítva.

Ennek egyik oka, hogy a filamentum képződés iniciátorai az aktin dimerek és trimerek rendkívül instabilak (2. ábra A), másrészről a monomer kötő fehérjék (profilin, thymosin $\beta 4$ ) megakadályozzák az aktin monomerek véletlenszerü összekapcsolódását (2. ábra B) [7]. Ezért az evolúció során létrejöttek olyan aktin nukleáló fehérjék, amelyek képesek elősegíteni aktin dimerek, trimerek kialakulását, illetve azok stabilizálódását. Alapvetően 4 alosztályba sorolhatjuk az aktin nukleációs faktorokat: tandem WH2 (Wasp homology domain 2) domén nukleátorok, Leiomodin fehérjék, Arp2/3 komplex és a forminok [모, 9]. Közös jellemzője az aktin nukleációs és az elongációs faktoroknak, hogy az aktin kötéshez túlnyomórészt WH2 vagy WH2-szerü doméneket használnak, kivéve a forminok többségét, amelyeknek az FH2 (Formin homology 2) doménje biztosítja az aktin kötést. A WH2 és az FH2 domének közvetlen szomszédságában gyakran prolin-gazdag domén (prolin-rich domain, PRD) található, amely a Profilin/G-aktin kötés kialakítását segíti elő. 


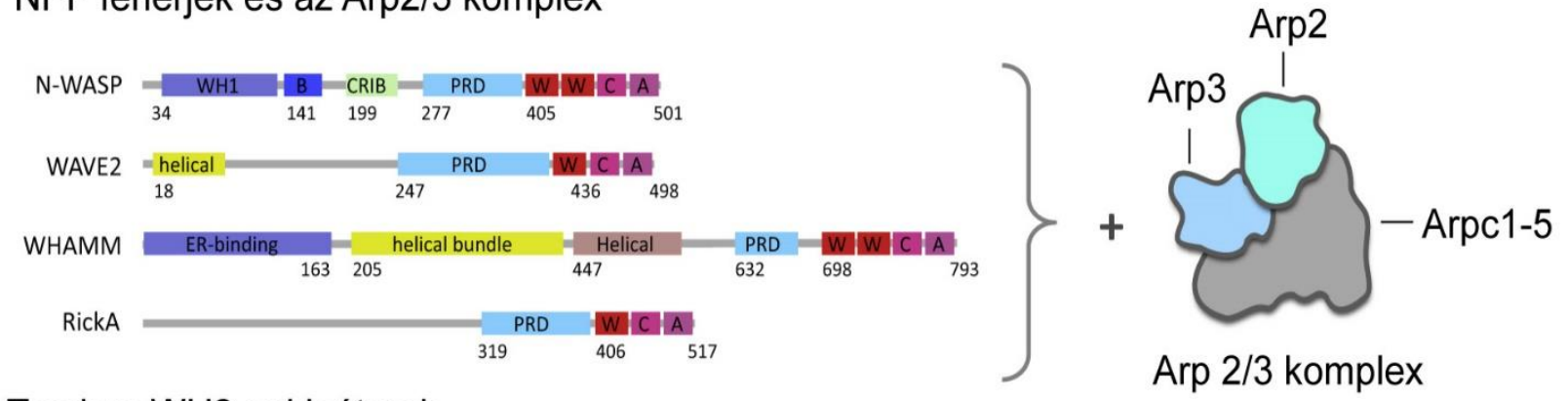

Tandem WH2 nukleátorok

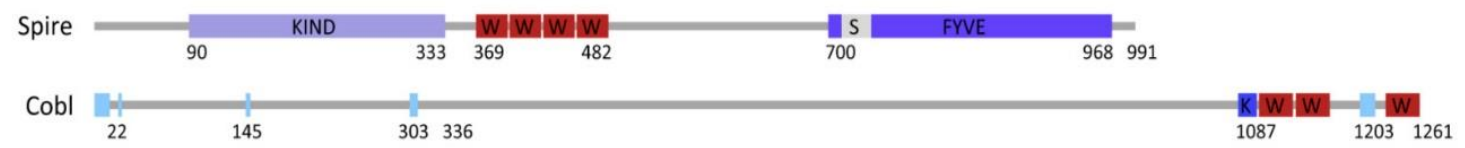

Leiomodin-szerủ nukleátor

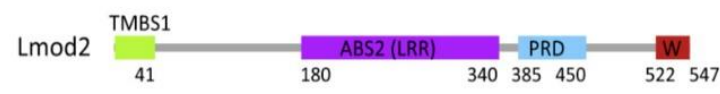

Formin nukleátorok WH2 doménnel

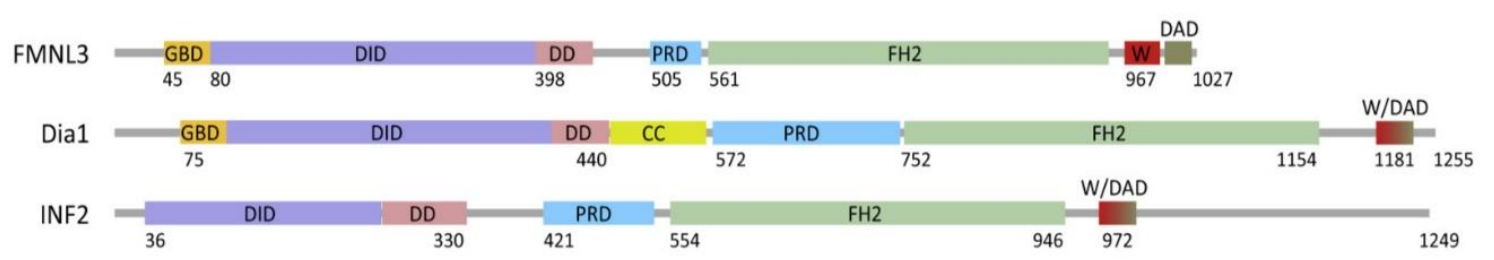

3. ábra WH2 vagy WH2-szerü doménnal rendelkező aktin nukleációs faktorok csoportosítása doménszerkezetük alapján. A WH2 domén piros négyzetben $\mathrm{W}$ jelöléssel van ellátva, míg a prolingazdag domén kék téglalap PRD felirattal. A domének rövidítései a következőek: KIND, kinase noncatalytic C-lobe domain; S, Spire box; FYVE, Fab1/YOTB/Vac1/EEA1zinc-binding domain; K, basic $\mathrm{K}$ region; SS, signal sequence; NRD, N-terminal repeat domain; CRD, C-terminal repeat domain; TMBS1, tropomyosin-binding site; ABS2, actin-binding site2; WH1,WASP-homology 1 domain; B,basic domain; CRIB, Cdc42/Rac interactive binding; C, centralregion; A, acidicregion; GBD, GTPase bindingdomain; DID, diaphanous inhibitory domain; DD, dimerization domain; FH2, formin- homology 2 domain; $\mathrm{DAD}$,diaphanous autoregulatory domain. Az ábra a [8]-as publikáció alapján módosítva.

\section{Az Arp2/3 komplex felépitése és müködése}

Az Arp2/3 komplex összesen hét protein alegységböl épül fel [10], amelyek közül kettő erősen hasonlít az aktinra (Arp2 és Arp3) [11]. Az Arp2 és Arp3 alegységek fehérje szekvenciái majdnem 50\%-os egyezést mutatnak az aktinnal, szerkezetük pedig olyan, hogy együttesen egy, a hegyes végen található aktin dimert mimikálnak, aminek szabad a szöges oldala, ahová aktin monomerek kapcsolódhatnak [12]. A két Arp a komplexben polimerizációs magként funkcionál, de ehhez még két feltételnek teljesülnie kell. Elöször is szükség van egy anyafilalamentumra, mivel az aktin monomerek jelenléte nem elégséges ahhoz, hogy új láncok képződését indítsa el. Ha az anyafilamentumhoz kötődik, akkor $70^{\circ}$-os szöget bezárva megindul az új aktin lánc kialakulása (4. ábra) [13]. Az Arp2/3 aktivitása ily módon hálózatos aktin 
struktúrák kialakulását teszi lehetővé, ahol az Arp2/3 az oldalágat alkotó aktin filamentumok hegyes végénél, az elágazódási pontokban helyezkedik el.

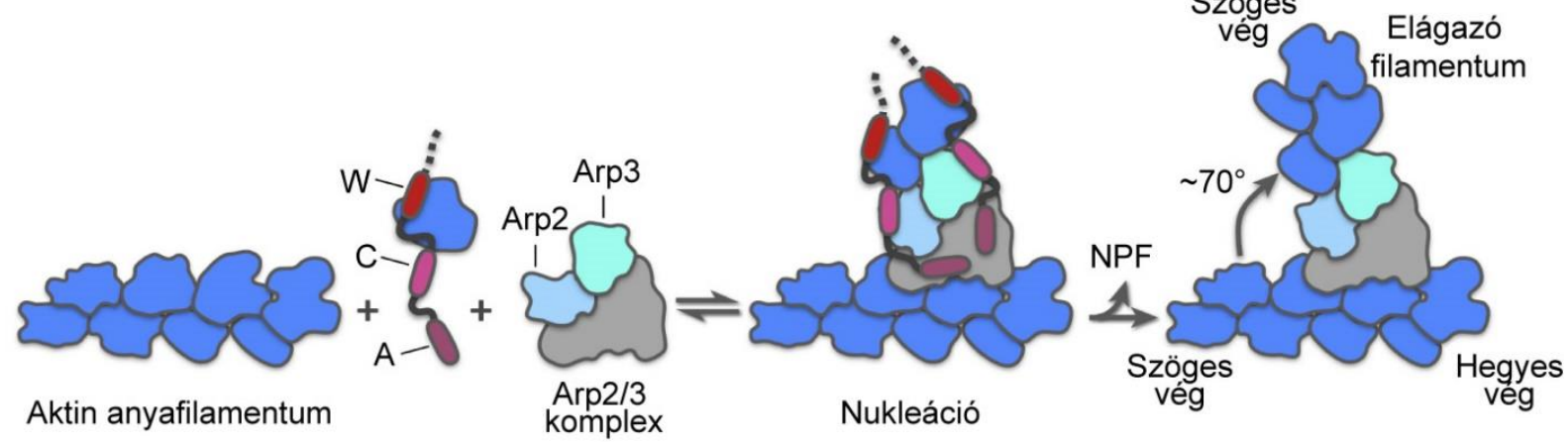

4. ábra Az NPF és az Arp2/3 komplex által katalizált aktin nukleáció mechanizmusának a modellje. Az Arp2/3 komplex 2 aktin-szerü doménnel rendelkezik. Az NPF aktiválja az Arp2/3 komplexet, ami egy filament-szerü struktúrát vesz fel, így elősegítve az NPF-Arp2/3 komplex kötődését az anyafilamentum oldalához. A filamentumhoz való kötődést követően az NPF segítségével aktin monomerek épülnek be, amik létrehozzák az aktin nukleációs magot a filamentum oldalán. A nukleáció után az NPF disszociál a filamentumról és ezáltal lehetővé teszi, hogy további aktin monomerek épüljenek be az elágazó filamentum szöges végére. A létrejövő új aktin filamentum és az anyafilamentum körülbelül $70^{\circ}$-os szöget zár be egymással. Az ábra a [] $]$-as publikáció alapján módosítva.

Ahhoz, hogy a két Arp a filamentum oldalához kötődjön, szükség van a fehérje aktivációjára is, mivel az alapállapotú Arp fehérjék konformációja nem teszi lehetővé a filamentumhoz való kötődést [13]. Az Arp2 és Arp3 fehérje aktivációját nukleációt elősegítő faktorok (nucleation-promoting factors, NPF) teszik lehetővé, amelyek elősegítik az Arp2 és 3 aktív konformáció változását, aktin monomert szállítanak az új filamentum szöges végéhez, illetve elősegítik az Arp2/3 komplex filamentumhoz való kötődését (4. ábra) [14-17]. Az NPF fehérjék közös jellemzője, hogy tartalmaznak a C-terminális részen PRD és WH2 doméneket,

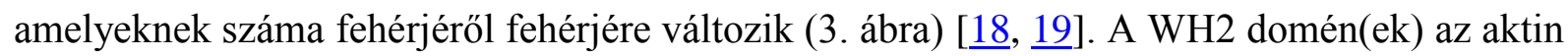
monomer(ek) kötődéséért felelősek lehetővé téve az új filamentum kialakulását. A PRD domének a Profilin/G-aktin kötést segítik elö, de szerepük még nem minden szempontból világos. A 4 legismertebb NPF fehérje: az N-Wasp, a Wave2, a WHAMM és a RickA (3. ábra) $[\underline{18}, \underline{19}]$.

Tandem WH2 nukleátorok felépitése és müködése

A tandem WH2 nukleátorok legelsőként azonosított tagja a Spire fehérje [20], amely tartalmaz egy N-terminális KIND domént, négy centrális aktinkötő WH2 domént, és egy C- 
terminális FYVE domént (3. ábra) [21]. A Spire által katalizált aktin nukleáció a Cappuccino formin fehérje segítségével együtt történik [22, 23]. A Spire-Capucciono fehérjekomplex létrejötte gátolja a formin nukleáló és szögesvég-kötő aktivitását, viszont ezzel párhuzamosan a Spire nukleáló aktivitása jelentősen megemelkedik [24, 25]. A Spire monomer fehérje, viszont a formin bekötődésével dimerizálódik, ami jelentősen megemeli a fehérje nukleációs aktivitását $[\underline{23}, \underline{26}]$. A nukleáció befejeztével a Spire elhagyja a szöges véget, ami lehetővé teszi a Profilin/G-aktin belépést a szöges végen (5. ábra).

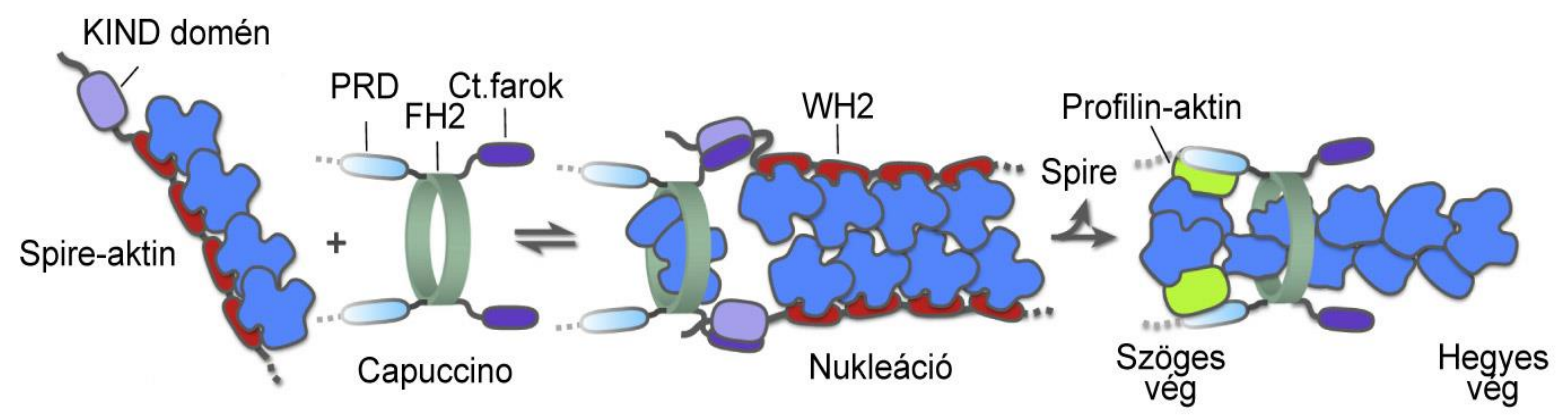

5. ábra A Spire aktin nukleációs faktor lehetséges müködési modellje. A Spire-aktin komplex (a 4 WH2 domén 4 aktin monomert köt) a Capuccino fehérjével kölcsönhatásba lép, ami a Spire dimerizálódását és nukleációs aktivitásának nagymértékü megemelkedését okozza. A nukleáció végén a Spire disszociálódik a filamentum szöges végéről biztosítva a lehetőséget új aktin monomerek beépülésének. Az ábra a []]-as publikáció alapján módosítva.

A tandem WH2 fehérjék másik fontos képviselője a Cordon bleu (Cobl) fehérje, amely kizárólag a gerincesekben fordul elö [27]. A fehérje az agyban nagymértékü kifejeződést mutat, ahol fontos szerepe van a dendrit arborizációban [28, 29]. Továbbá a Cobl fehérje nukleációs aktivitása összefüggésbe hozható az elsődleges cílium képződéssel valamint a mikrovillus összeszerelődéssel [30-33]. A Cobl fehérje, hasonlóan a Spire-hoz, több aktin monomert képes megkötni, amely aktivátor fehérjék (BAR és SH3 domént tartalmazó fehérjék) hatására dimerizálódik és elősegíti az aktin filamentumok nukleációját [년, $\underline{35]}$. Azonban a Cobl fehérje müködésének néhány aspektusa különbözik a Spire fehérjétöl. A Cobl a Spire-től eltérően mindössze 3 WH2 domént tartalmaz, valamint a második és a harmadik WH2 domén között talaláható 65 aminosav hosszúságú linker (összekötő fehérjerész) kulcsfontosságú a fehérje nukleációs aktivitásában (3. ábra) [34, $\underline{35}]$. Az első WH2 domén előtt található egy lizinben gazdag fehérjerész, amely aktin-kötésre képtelen, de szintén szükséges a WH2 domének aktivitásához. A rendelkezésre álló ismereteink alapján ez a lizinben gazdag régió képes lehet a BAR és SH3 doméneket tartalmazó fehérjékkel interakcióba lépni, ami elősegíti a fehérje

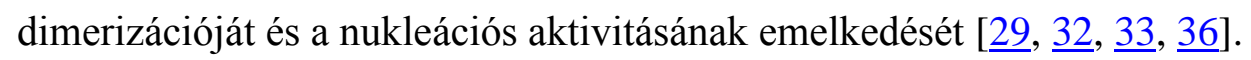




\section{Leiomodin-szerü nukleációs faktorok}

Az aktin nukleációs faktorok legkésőbb felfedezett képviselője a Leiomodin (Lmod), amelyet egy izom specifikus aktin nukleátorként jellemeztek [37]. Az Lmod izomspecifikus müködése mindenképpen kivétel az aktin nukleátorok között, mivel a filamentum hegyes végén stabilizálja az aktin nukleációs magokat $[\underline{38}, \underline{39}]$ (6. ábra).

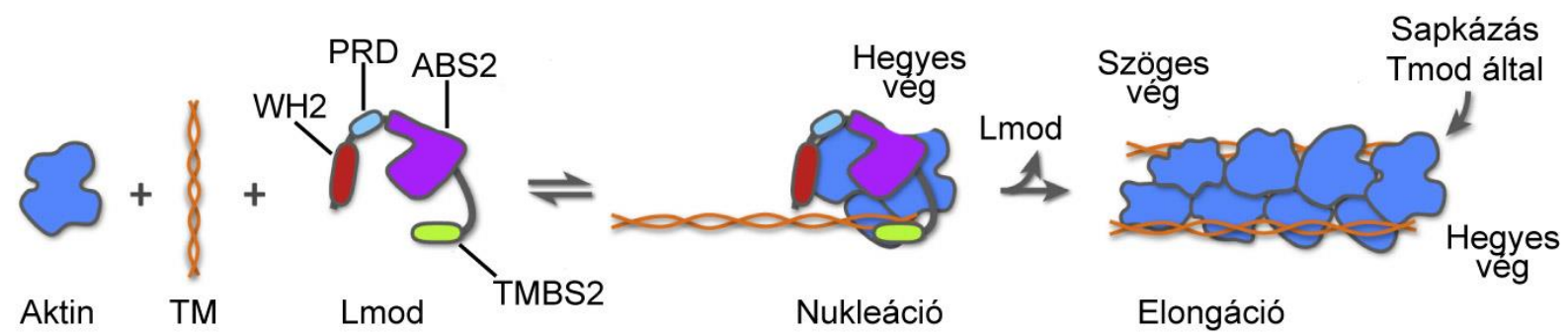

6. ábra Az Lmod feltételezett müködési mechanizmusa az izom fejlödés során. Az Lmod a két aktinkötő fehérjerész (actin binding site 2, ABS2 és WH2) mellett rendelkezik egy tropomiozin interakciós doménnel (tropomyosin binding site 2, TMBS2) és egy prolin-gazdag régióval (PRD). Az ABS2 a WH2 és a PRD domének közremüködésével létrehozza a nukleációs magként szolgáló trimert. A nukleáció után a hegyes végről disszociál és ezáltal a Tmod sapkázza a filamentumvéget. Az ábra a []]-as publikáció alapján módosítva.

\section{A forminok jellemzése}

A forminok nagyfokú evolúciós konzerváltságot mutató fehérjék, amelyek képesek befolyásolni a sejtváz dinamikus folyamatait az aktin és a mikrotubulus sejtváz szabályozása által. Rendkívül fontos folyamatokban vesznek részt, mint pl: sejtalak változás, sejtosztódás stb. A formin fehérjecsalád első névadó tagja az egér Formin-1 gén volt. A formin, mint elnevezés a gén mutációja által okozott „limb deformity” fenotípusból származik. A Formin-1 homozigóta mutáns egerek vese- és végtagdeformitási fenotípust mutattak [40]. A későbbi vizsgálatok során azonban kiderült, hogy a mutáns fenotípust valójában a Formin-1 génnel szomszédos gremlin nevü gén hibás szabályozása okozza [41]. Ettől függetlenül a formin elnevezés megmaradt és a később azonosított Formin-1 homológok megtartották nevüket. A forminok az élővilágban széles körben elterjedtek, mivel az élesztőktől kezdve a gerincesekig szinte minden fajban megtalálhatóak [42]. Ezek a fehérjék sokféle sejttípusban és szövetben kifejeződnek, és sokféle sejtes struktúra létrehozásában játszanak szerepet $[\underline{42}, \underline{43}]$.

A forminok nagyméretü (120-220 kDa), dimerizációra képes multidomén szerkezettel rendelkező fehérjék [44]. A forminok közös jellemzője, hogy rendelkeznek két formin 
homológia doménnel (FH1 és FH2) [43, 44]. A metazoa forminok FH2 doménjeinek összehasonlító filogenetikai analízise alapján a forminokat 7 nagyobb alcsaládra oszthatjuk: Diaphanous (Dia), Dishevelled-associated activator of morphogenesis (DAAM), formin-like proteins (FMNL), formin homology domain proteins (FHOD), formins (FMN), Delfilin és inverted formins (INF) [45]. Az eukarióta sejtek több formin gént tartalmazhatnak, de az egyszerübb élőlényekben nem minden formin alcsalád képviselteti magát. A bioinformatikai vizsgálatok alapján a Saccharomyces cerevisiae-ben 2, a Schizosaccharomyces pombe-ban 3, a Drosophila melanogaster-ben 6, a Dictyostelium discoideum-ban 10, az emlösökben 15 formin gén található (7. ábra) [42].

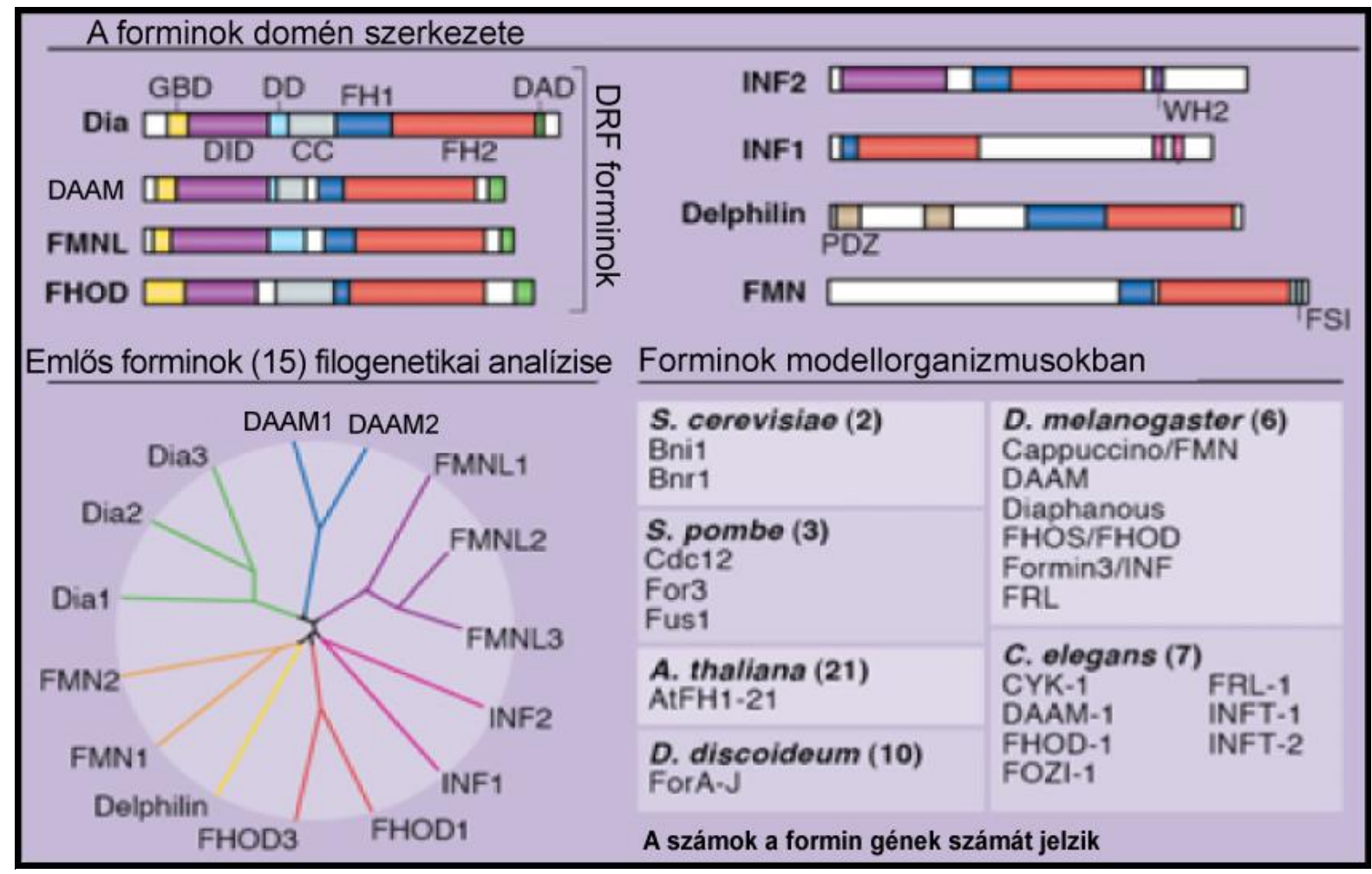

7. ábra A forminok domén szerkezete és filogenetikai vizsgálata. Az emlős forminokat 7 nagyobb alcsaládba sorolhatjuk: Dia, DAAM, FMNL, FHOD, INF, Delfilin és FMN. A DRF forminok csoportjába (Dia, DAAM, FMNL, FHOD) tartozó fehérjék nagyfokú szerkezeti és funkcionális hasonlóságot mutatnak egymással. Drosophila-ban a Delfilint kivéve az összes formin alcsalád képviseli magát. Az ábra a [42]-es publikáció alapján módosítva.

A forminok FH1 doménje a Dictyostelium discoideum ForC-t kivéve [46] minden forminban megtalálható, változó méretü, körülbelül 50 aminosavból álló prolin-gazdag régió közvetlenül az FH2 domén szomszédságában. Az FH1 domén egyik legfontosabb ismert funkciója, hogy képes megkötni a Profilin/G-aktin komplexet [47-50]. Továbbá ismert tény, hogy az FH1 domén prolinban gazdag része interakcióba kerülhet WW vagy SH3 doméneket tartalmazó fehérjékkel [51-54]. 
Az FH2 domén legjobban jellemzett tulajdonsága, hogy in vitro körülmények között képes nukleálni és elongálni az aktin filamentumokat [55-57]. Ellentétben a többi aktin nukleáló faktorral, képes a nukleáció után a filamentum szöges végén maradni, hogy megóvja a filamentumvéget a sapkázó fehérjéktől, illetve elősegítse a filamentum elongációját [58-60]. Az eddigi tudásunk szerint az FH2 domének csak homodimer formában aktívak, mivel a dimerizációt érintő mutációk megszüntetik a fehérje nukleáló aktivitását [59-61]. A kristályszerkezeti vizsgálatok megmutatták, hogy az FH2 domének dimerizációjával egy gyürüszerü képlet jön létre [60]. A müködési modell alapján az FH2 dimer eleinte két aktin monomert köt, amely a későbbiekben nukleációs magként szolgál. Zárt állapotban ez a kötődés olyan szoros, hogy lehetetlenné teszi további aktin monomerek beépülését. Az FH2 dimer a zárt konformáció után képes nyitott állapotba kerülni azáltal, hogy a gyürü felnyílik az egyik oldalon, így képes egy új aktin monomer beépülni. A monomer beépülése után a gyürü ismét zárt konformációt vesz fel. A zárt és nyitott állapot felváltva váltakozik az aktin polimerizáció folyamán, amely során a formin mintegy végig lépked a szöges végre beépülő G-aktin monomereken és folyamatosan asszociált marad a gyorsan növekvő véggel (8. ábra) [58]. Ez a forminok aktin polimerizációjának egy általánosan elfogadott modellje, azonban a konformáció-változás mechanizmusa egyelőre nem világos.

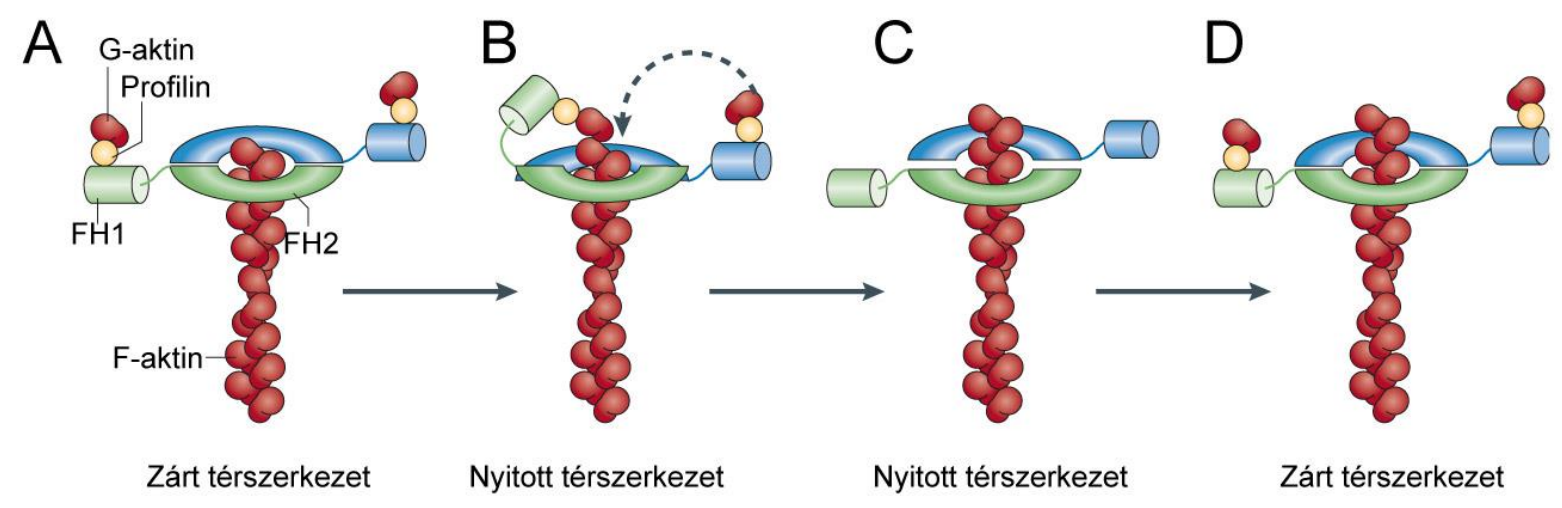

8. ábra A forminok általános múködési modellje. (A) Az FH2 dimer az aktin filamentumok szöges végéhez kötődik, az aktin polimerizációhoz szükséges monomereket az FH1 domén biztosítja a Profilin/G-aktin megkötésével. (B) Az FH1 domén a Profilin kötött monomert a szöges vég közelébe szállítja, ahol az FH2 dimer egyik funkcionális fele beépíti az aktin monomert a filamentum végére. (C) A másik FH2 domén megismétli ugyanezt a folyamatot. (D) A formin zárt konformációja megvédi a filamentumvéget a sapkázó fehérjék hozzákötődésétől. Az ábra a [18]-as publikáció alapján módosítva.

A 7 formin alcsalád közül érdemes kiemelni a DRF (diaphanous related formins) forminok közé tartozó Dia, DAAM, FMNL és FHOD alcsaládokat, amelyek a doménszerkezeten kívül funkcióban is nagy hasonlóságot mutatnak egymással. A DRF 
forminokra jellemző, hogy a formin homológia doméneken kívül más konzervált doméneket is tartalmaznak és alapvetően a fehérje két nagyobb funkcionális részre különíthető el (9. ábra) [62-66].
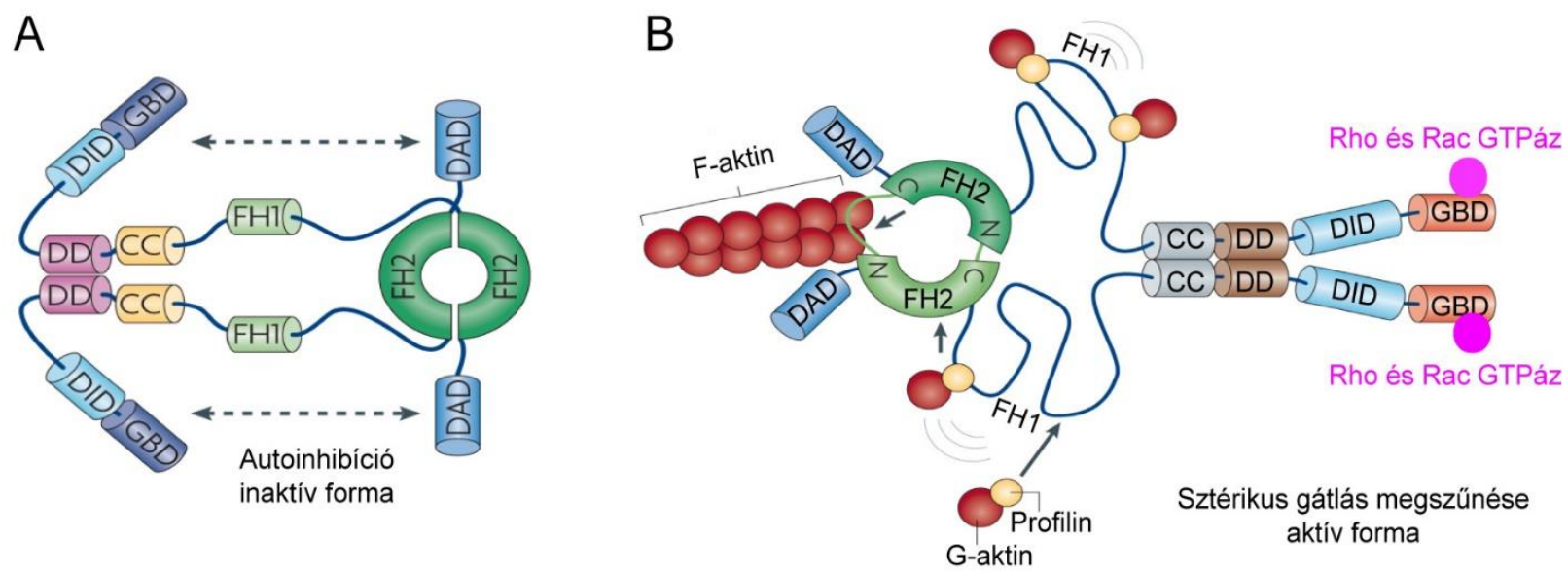

9. ábra A DRF forminok doménszerkezete és müködése. (A) Az autoinhibíció a C-terminális DAD és az N-terminális DID domének kölcsönhatásával jön létre. (B) Egy Rho- vagy Rac-típusú kisGTPáz GBD doménhez történő kapcsolódásával az intramolekuláris kapcsolat megszünik, így a formin aktív állapotba kerül. Ezek után az FH2 domén képes elősegíteni az aktin filamentumok nukleációját, majd a polimerizáció során a gyorsan növekvő véggel asszociált marad. Az FH1 domén kölcsönhatása a Profilin/G-aktin komplex-szel jelentősen gyorsíthatja az elongáció sebességét. A domének rövidítései a következőek: CC, coiled-coil ; DAD, diaphanous autoregulatory domain; DD dimerization domain; DID, diaphanous inhibitory domain; FH1, formin homology 1; FH2, formin homology 2; GBD, GTPase-binding domain. Az ábra a [44]-es publikáció alapján módosítva.

A C-terminális felükben helyezkedik el a két katalitikus formin homológia domén, a DAD domén (diaphanous autoregulatory domain) és az extrém C-terminális rész. Az N-terminális régióról úgy gondoljuk, hogy leginkább szabályozó funkciókkal bír, amelyek közül kiemelkedik, hogy intramolekuláris kölcsönhatást létesít a DAD doménnel és ezáltal gátolni képes a C-terminális fél aktin összeszerelő aktivitását (9. ábra A) [66-68]. A fehérje Nterminális felében négy funkcionális domén található, a GBD (GTPase-binding domain), a DID (diaphonous inhibitory domain), a DD (dimerization domain) és a CC (coiled-coil) domének (9. ábra) $[\underline{64}, \underline{65}]$. A DD és a CC domének az N-terminális fél dimerizációját segítik elő és szerepük lehet a sejten belüli lokalizáció szabályozásában is [64]. Ezzel szemben a GBD és a DID domének a DAD doménnel való kölcsönhatást irányítják [ㄷ]. Ha egy aktivált Rho típusú kisGTPáz kötődik a GBD doménhez, akkor megszünik az intramolekuláris kölcsönhatás (9. ábra B) $[\underline{63}, \underline{68}$. A mai ismereteink szerint a Rho típusú kisGTPázok a DRF családba tartozó forminok legfontosabb aktivátorai [69]. A C-terminális félen az FH1 és FH2 domének 
szomszédságában a DAD domén és a C-terminális farok rész található. A C-terminális részen lévő DAD domén amellett, hogy részt vesz a fehérje inaktív konformációjának kialakításában, az extrém C-terminális résszel együtt képes növelni az aktin polimerizáció sebességét [70-72]. A DAD és a C-terminális farok rész egyaránt pozitívan töltött aminosavakban gazdagok, így valószínüleg elősegítik az aktin-formin interakció kialakulását.

\section{A mikrotubulusok általános jellemzése}

A mikrotubulusok olyan nem kovalens sejtváz polimerek, amelyek minden eukarióta sejtben megtalálhatóak és számos folyamatban részt vesznek, mint pl: mitózis, sejtvándorlás, intracelluláris transzport, szekréció és sejtalak fenntartás. A mikrotubulusok a sejtek legmerevebb vázelemei, amelyek a stabilitás szempontjából viszont dinamikusan változó szerkezetek. Az $\alpha$ - és $\beta$-tubulin heterodimerek a polimerizáció első lépésében protofilamentumokat hoznak létre, amelyek ezután egy $24 \mathrm{~nm}$ széles cilindrikus csőszerü struktúrába rendeződnek, így hozva létre a mikrotubulust (10. ábra) [73-76]. A dimerek beépülése a protofilamentumba fej-farok orientációban történik, a tubulin dimer $\alpha$ alegysége a következő dimer $\beta$ alegységével kapcsolódik össze [ㄷ]. Az aktin filamentumokhoz hasonlóan a mikrotubulusok szintén polarizált struktúrákba rendeződnek, és két különböző polimerizációs rátával rendelkező végük van [76-78]. A (+) végen jelentősen gyorsabb a polimerizáció sebessége, míg a (-) végen ennél lényegesen lassabb. Minden egyes protofilamentumban megfigyelhető, hogy a $(+)$ vagy gyorsan növekvő végen az $\alpha$ - és $\beta$-tubulin heterodimerek $\beta$ alegységei, míg a (-) vagy lassan növekvő végen pont fordítva a heterodimerek $\alpha$ alegységei lógnak ki (10. ábra) [78]. A harmadik tubulin izoforma a $\gamma$-tubulin, amely a (-) végen iniciátora a megfelelő mikrotubulus összeszerelődésnek [79]. A de novo mikrotubulus képződés legfőbb nukleációs komplexe a $\gamma$-tubulin gyürü komplex ( $\gamma$-TuRC) [80-82]. A polimerizáció/depolimerizáció dinamikája nagymértékben függ egyrészt a tubulin dimerek koncentrációjától, másrészt a $(+)$ végen a szabad $\beta$-tubulin GTP vagy GDP kötött állapotától. Egy bizonyos tubulin koncentráció felett elsődlegesen beépülés, míg ez alatt depolimerizáció történik. Ha a $(+)$ végen túlnyomórészt GDP-kötött $\beta$-tubulin alegységek találhatóak, akkor az

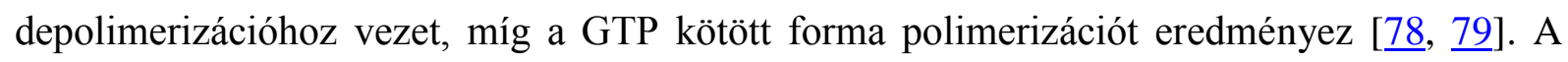
mikrotubulusok tulajdonságait jelentősen befolyásolja, hogy milyen $\alpha$ - és $\beta$-tubulin izoformából épülnek fel, $3 \alpha$-tubulin ( $\alpha 1, \alpha 2$ és $\alpha 4$ ) és $5 \beta$-tublin ( $\beta I, \beta I I, \beta I I I, \beta I V a$ és $\beta I V b)$ izoformát különböztethetünk meg egymástól [푸 $\underline{84}]$. Továbbá különböző mikrotubulus asszociált fehérjék kötődése, illetve a mikrotubulusok poszttranszlációs módosításai 
(tirozináció, detirozináció, actiláció, poliglutmailáció, poligliciláció, foszforiláció és palmitoiláció) is fontos tényezői a mikrotubulus dinamika szabályozásának [ㄷ5-87].

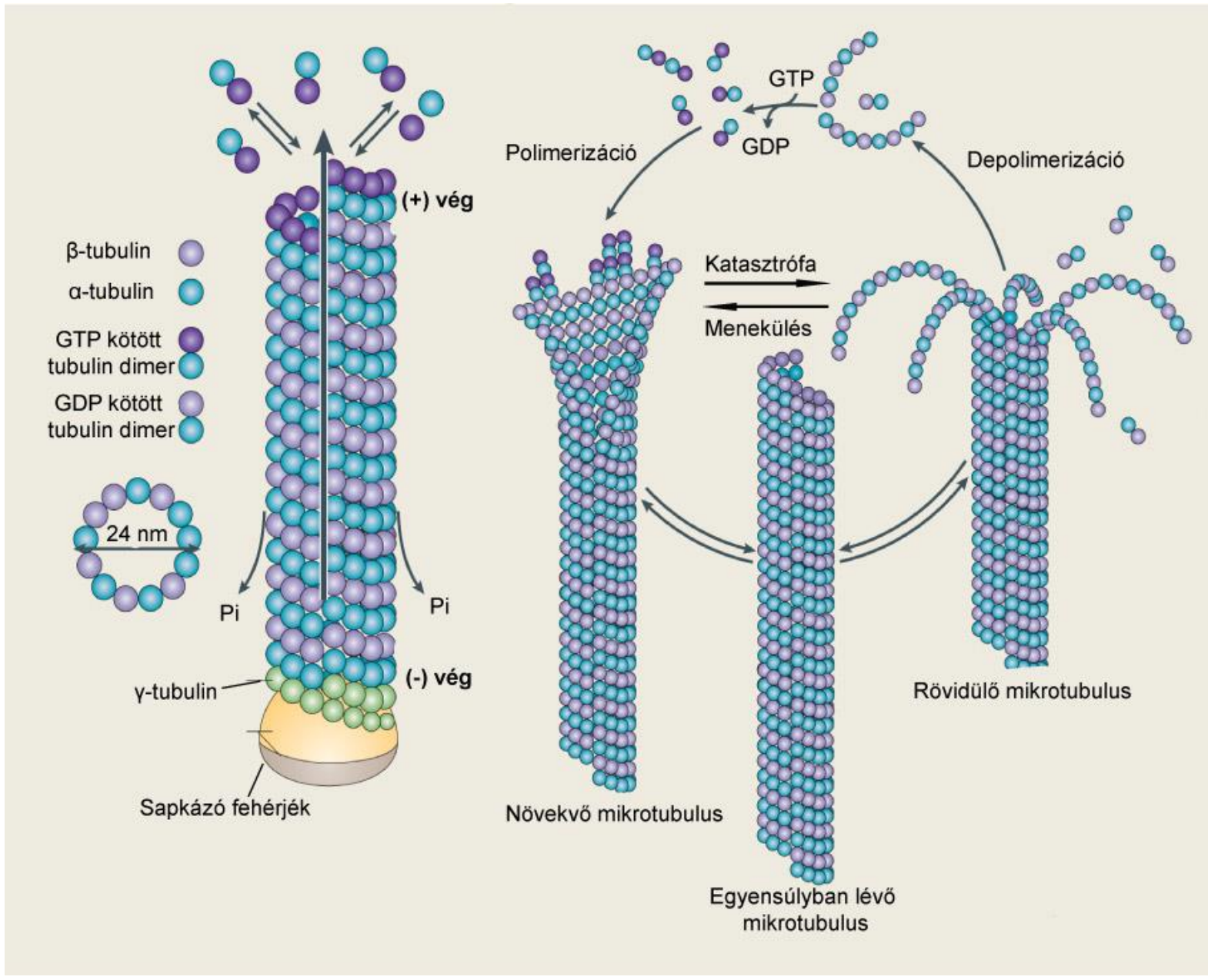

10. ábra A mikrotubulusok felépítése és működése. A mikrotubulusok fej-farok orientációban elhelyezkedő $\alpha$ - és $\beta$-tubulin heterodimerekből épülnek fel. A mikrotubulusok polarizált szerkezetű struktúrák, amelyek $(+)$ végénél a polimerizáció sebessége lényegesen nagyobb, mint a (-) végnél. A mikrotubulusvégek felépülésének (polimerizáció) és leépülésének (depolimerizáció) dinamikája periodikusan változik, amelyet dinamikus instabilitásnak hívunk. A dinamikus instabilitás során a mikrotubulus gyorsan növekvő végei hirtelen átváltanak depolimerizációba (katasztrófa), majd hirtelen újra növekedni kezdenek (menekülés). Az ábra a [95]-ös publikáció alapján módosítva.

\section{A mikrotubulus nukleáció}

A nukleáció során a $\gamma$-tubulin létrehozza a multiprotein $\gamma$-TuRC komplexet, ami templátként szolgál a létrejövő mikrotubulus $\alpha$ - és $\beta$-tubulin alegységeinek [8]. Habár a $\gamma$ tubulin legnagyobb részt a centroszómáknál lokalizálódik, mégis megfigyelhető centroszómális és nem centroszómális $\gamma$-tubulin mediált nukleáció [89]. Továbbá az is ismert tény, hogy centroszómák hiányában a sejtek mikrotubulus szerveződése normális [900, 911]. Ezek az eredmények azt sugallják, hogy centroszómák nélkül is létrejöhetnek új mikrotubulus kötegek. 
A centroszómától független mikrotubulus nukleáció során a sejtosztódás után a $\gamma$-tubulin és számos centroszómális fehérje a citoplazmában fogja kialakítani az új mikrotubulus nukleációs helyeket [92].

\section{A mikrotubulus dinamika szabályozása}

A mikrotubulus növekedés vagy rövidülés az $\alpha$ - és $\beta$-tubulin heterodimerek beépülésével vagy leválásával valósul meg. A növekedés mértéke elsősorban az oldat szabad heterodimer koncentrációjától függ. A csővégen az újonnan beépült $\beta$-tubulin a hozzákapcsolt GTP molekulát elhidrolizálja, ami azt eredményezi, hogy a mikrotubulus cső falában már GDP kötött $\beta$-tubulin lesz. A hidrolízis csökkenti az $\alpha$ - és $\beta$-tubulin heterodimerek közötti kötés erősségét, ami elősegíti a GDP kötött dimer leválását a mikrotubulusról. A mikrotubulus növekedése, akkor figyelhetö meg, ha a GTP-tartalmú dimerek beépülése gyorsabb, mint az ezt követő GTP-hidrolízis. Ilyenkor a mikrotubulus végén egy GTP-tartalmú dimerekből álló felszíni réteg alakul ki, amely megakadályozza a cső végének a leépülését. Ha a GTP kötött heterodimer beépülés lelassul a GTP-tartalmú heterodimerek lokális koncentrációjának csökkenése miatt, akkor a felszíni GTP kötött dimer réteg eltűnhet. Ezt követően a csővégeken a GTP hidrolízis következtében GDP-tartalmú dimerek halmozódnak fel, ami instabilitáshoz és felbomláshoz vezethet. A miktotubulusok azt a tulajdonságát, amikor periodikusan változik a mikrotubulusvégek növekedési és rövidülési fázisa, dinamikus instabilitásnak nevezzük (10. ábra) [국 78, 93]. A mikrotubulusvég környezetében lévő szabad GTP kötött heterodimer koncentráció mellett még számos tényező befolyásolja a mikrotubulus dinamikát. Számos fehérjéről ismert, hogy interakciójuk a mikrotubulusokkal befolyásolja a mikrotubulusok növekedését, ezek közül a legjelentősebbek a mikrotubulus asszociált (MAP) fehérjék, a motorfehérjék, a poszttranszlációs módosításokat katalizáló enzimek és a (+) végkötő fehérjék $[\underline{94}, \underline{95}]$.

\section{Mikrotubuluskötő + TIP fehérjék}

A mikrotubuluskötő fehérjék legnagyobb és legismertebb csoportja a $(+)$ végkötő vagy +TIP (microtubule plus-end tracking proteins) fehérjék. Az első azonosított +TIP fehérje a CLIP170 volt, azóta több, mint 20 +TIP fehérjecsaládot ismerünk. A szerkezeti felépítésük alapján 5 nagyobb csoportra oszthatjuk a +TIP fehérjéket (11. ábra) [96, 97]. 


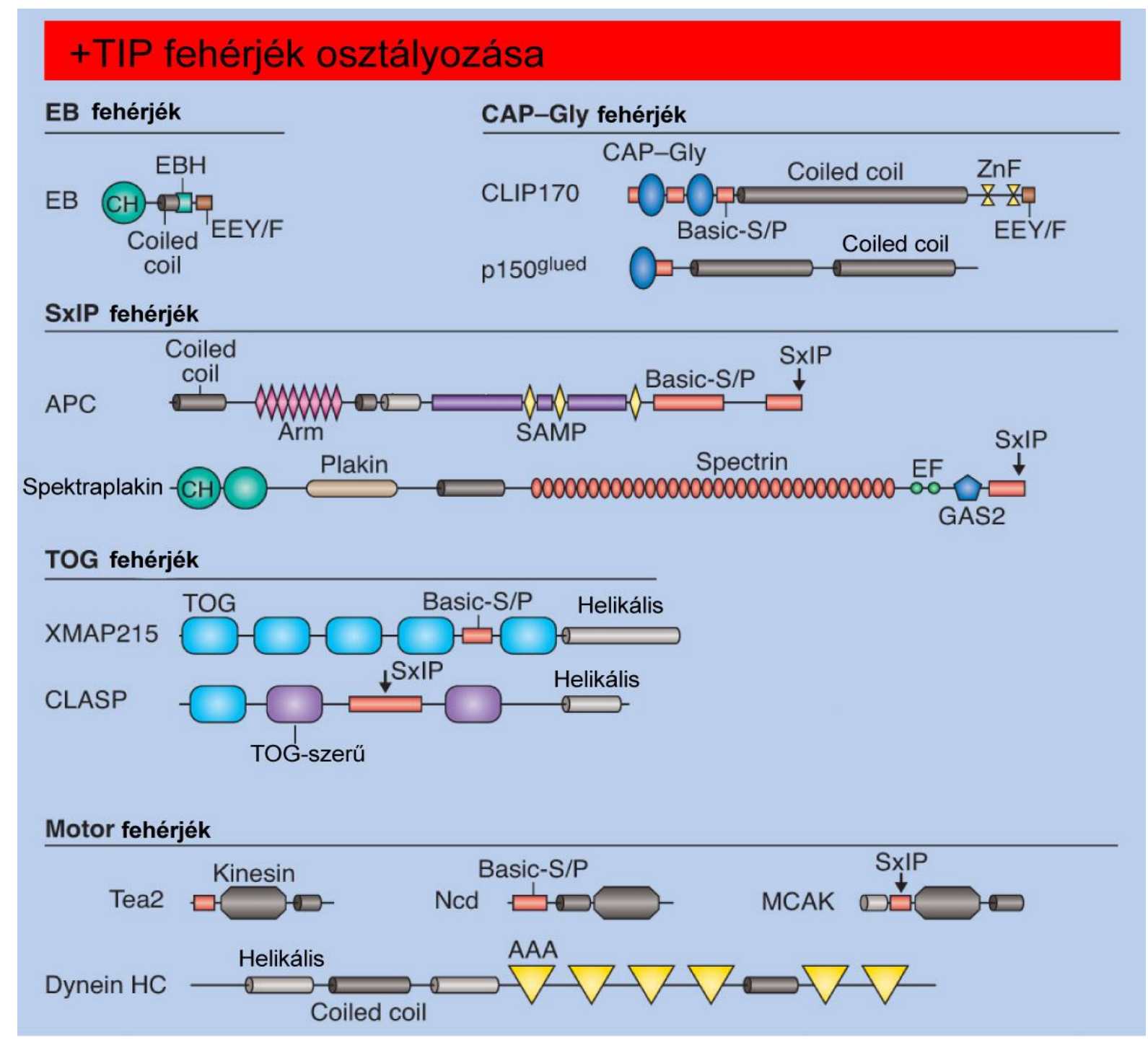

11. ábra A + TIP fehérjék csoportosítása domén szerkezetük és funkcióik alapján. A fehérjék és a domének rövidítései a következőek: APC, adenomateous polyposis coli protein; Arm, armadillo repeat; basic-S/P, bázikus valamint szerin és prolin aminosavban gazdag; CAP-Gly, cytoskeleton-associated protein glycine-rich; $\mathrm{CH}$, calponin homology; CLASP, CLIP-associated protein; CLIP-170, cytoplasmic linker protein of $170 \mathrm{kDa}$; EB, end-binding protein; EBH, EB homology; EEY/F, C-terminális Glu-GluTyr/Phe tripeptid motívum; EF-hand, Ca2+-kötő motívum; Gas2, growth-arrest-specific protein 2; MCAK, mitotic centromere-associated kinesin; SxIP, Ser-x-Ile-Pro tetrapeptid motívum, ahol X bármilyen aminosavat jelölhet; +TIP, microtubule plus-end tracking protein; TOG, chTOG; WD40; XMAP215, microtubule-associated protein of $215 \mathrm{kDa}$. Az ábra a [96]-os publikáció alapján módosítva.

A végkötő (end binding, EB) fehérjék az N-terminális részükön egy erősen konzervált $\mathrm{CH}$ (calponin homology) doménnel rendelkeznek, amely a mikrotubulus kötésért felelös [98]. Ezenkívül a fehérje C-terminális részén található a helikális coiled-coil domén, amely a dimerizációt segíti elő. Irodalmi adatok alapján úgy tünik, hogy dimerizáció hiányában nem képes az EB fehérje a $(+)$ véghez kötődni [99]. A dimerizációért felelős fehérjerész mellett 
megtalálható még az EBH (EB homology) domén és a savas aminosavakat tartalmazó EEY/F motívum, amelyek lehetővé teszik, hogy a fehérje más +TIP fehérjékkel kölcsönhatásba kerüljön a mikrotubulusvégen (11. ábra) [100, 101].

A következő csoport a CAP-Gly (cytoskeleton associated protein glycine rich) doménnel rendelkező fehérjék. A CAP-Gly fehérjerész erősen hidrofób tulajdonsággal bír és lehetővé teszi, hogy a fehérje kapcsolódni tudjon a mikrotubulusokhoz, illetve az EB fehérjékhez [102, 103]. Jeles képviselői ennek a fehérjecsaládnak a CLIP-170 és a dynactin komplex nagy alegysége a p150 ${ }^{\text {glued }}$. A CLIP-170 a CAP-Gly doménjének segítségével kötődik a mikrotubulusokhoz (11. ábra) [104].

A +TIP fehérjéknek a legnagyobb csoportja egy 4 aminosavas SxIP (szerin, x aminosav, ileucin, prolin) motívumot tartalmaz. Az SxIP motívum elsődleges funkciója, hogy specifikusan felismerje az EB fehérjék EBH doménjét [105]. A fehérjecsalád legismertebb képviselői az APC (adenotamous polyposis coli) tumor szupresszor, a mikrotubulus-aktin keresztkötő Spektraplakin és a mitotikus centromer asszociált kinezin (MCAK). Mivel az SxIP motívum kisméretü, ezért a fehérjék az evolúció során meglehetősen könnyen meg tudják szerezni, illetve el is tudják veszíteni ezt a rövid szekvenciarészletet, amire számos példát találhatunk az irodalomban (11. ábra) [106].

A TOG vagy TOG-szerü doménnal rendelkező fehérjék közé tartozik az XMAP215/Dis1 fehérjecsalád valamint a CLASP (CLIP-associated protein) fehérjék. A fehérje tandem helyzetben lévő TOG doménjeinek interakciója a tubulin dimerekkel valószínűleg elősegíti a mikrotubulusok növekedését [107]. A CLASP fehérje a TOG doméneken kívül SxIP motívummal is rendelkezik, ami szükséges a fehérje (+) vég lokalizációjához (11. ábra) [108].

Az utolsó + TIP fehérje csoport a mikrotubulus alapú motorfehérjék. A mikrotubulus mentén a (+) és a (-) irányba mozgó motorfehérjék egyaránt megtalálhatóak a gyorsan növekvő mikrotubulusvégen. Élesztőben a legismertebb +TIP motorfehérjék a kinezin Tea2, illetve a Kip2, a mikrotubulus depolimerizáló kinezin 13 MCAK és a citplazmatikus dinein. Az MCAK esetében valószínüleg a mikrotubuluskötő motor domén előtt található SxIP motívum segíti elő a (+) vég lokalizációt (11. ábra) [109].

A +TIP fehérjék nagyon fontos vonása, hogy egy bonyolult, dinamikusan változó interakciós hálózatot képesek kialakítani a mikrotubulus $(+)$ végen, amelyet a fehérjék jellegzetes doménjei és szekvencia motívumai biztosítanak, mint pl: $\mathrm{CH}$, EBH és CAP-Gly domének, illetve EEY/F és SxIP motívumok [103, 104]. A jelenlegi ismereteink alapján úgy tünik, hogy ennek a +TIP/mikrotubulus hálózatnak a központi elemei az EB fehérjék, mivel más fehérjéktől függetlenül is képesek szabályozni a gyorsan növő mikrotubulusvéget [오, $\underline{110}$, 
111]. Továbbá az EB fehérjék szinte az összes többi +TIP fehérjével képesek kölcsönhatásba lépni. Ez a rendkívül bonyolult és összetett kölcsönhatási hálózat a +TIP fehérjék és a mikrotubulusok között, lehetővé teszi azt, hogy a +TIP fehérjék képesek legyenek finoman szabályozni a mikrotubulus dinamika különböző aspektusait, mint például a tubulin dimerek beépítésének elősegítése [112], katasztrófa [113] vagy menekülés [114] indukálása, illetve a mikrotubulusok stabilizálása.

A mikrotubulus dinamika szabályozása mellett a +TIP komplexek-nek fontos szerepe van abban, hogy a mikrotubulusvégeket kihorgonyozzák bizonyos struktúrákhoz, mint pl. a sejtmembrán [115] vagy a mitótikus kinetokór [116]. A +TIP komplex valószínüleg az aktin/mikrotubulus rendszer kommunikációjában is részt vesz, amely kulcsfontosságú az axon növekedés és navigáció folyamataiban [117].

Néhány +TIP esetében azonban néha elég ellentmondásos a kép a funkció szempontjából. Egy jó példa erre az EB fehérje, ugyanis in vivo a sejtekben rendszerint elősegíti a mikrotubulusok növekedését és szupresszálja a katasztrófát, viszont in vitro körülmények között képes pozitív és negatív irányba is befolyásolni a növekedést $[\underline{110}, \underline{111]}$. Mindent egybe véve a mikrotubulus dinamika szabályozása egy nagyon fontos +TIP funkció, ami nagyon sok elemében még csak részlegesen feltárt folyamat.

\section{Strukturális mikrotubulus asszociált fehérjék}

A strukturális mikrotubulus asszociált fehérjék (microtubule associated protein, MAP) legismertebb képviselői a MAP1B és a tau, amelyek szabályozzák a mikrotubulus organizációt és dinamikát a neuronális fejlődés során $[\underline{118}, \underline{119}]$. Mind a MAP1B mind a tau szükséges az axon képződésben. Az in vitro biokémiai és in vivo sejtes kísérletek alapján kiderült, hogy a MAP1B (12. ábra) és a tau is képes közvetlenül a mikrotubulusokhoz kötődni és stabilizálni azokat. A tau fehérje a stabilizáló funkciója mellett képes megóvni a mikrotubulusokat attól, hogy bizonyos fehérjék (pl. katanin) szétszereljék öket [120]. Számos neurodegeneratív betegség esetében leírták, hogy a tau hiperfoszforilált formája, amely nem képes a mikrotubulusokhoz kötődni, az átlagosnál jóval nagyobb mennyiségben van jelen [121]. A MAP1B Drosophila homológja a Futsch szintén jelentős szerepet játszik az idegrendszer kialakulásában $[\underline{122}, \underline{123}]$. 


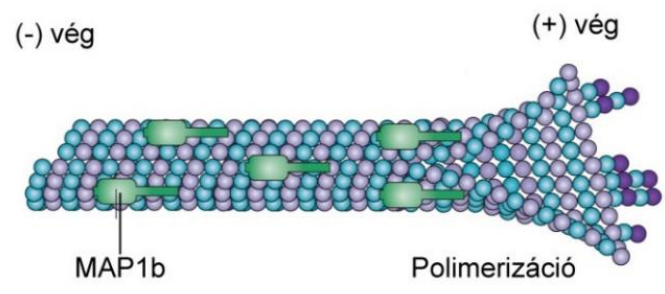

12. ábra A MAP1B kötődése a mikrotubulusokhoz. A MAP1B képes a mikrotubulusok oldalához kötődni, ami stabilizálja azokat. A fehérje kötődése elösegíti a mikrotubulusok növekedését a gyorsan növő (+) végen. Az ábra a [95]-ös publikáció alapján módosítva.

\section{A forminok és a mikrotubulusok}

Egyre több bizonyíték van arra vonatkozólag, hogy a forminok az aktin összeszerelő aktivitásukon kívül képesek kötni és szabályozni a mikrotubulusokat is [44, 124]. Először a Dia, FMN és INF formin alcsaládokról derült ki, hogy szerepet játszhatnak a mikrotubulusok szabályozásában [125-128]. A forminok in vivo szerepét a legtöbb modellrendszerben nehéz vizsgálni, mert az aktin sejtváz nagymértékben befolyásolja a mikrotubulus szerveződést [44]. Ezért az in vitro biokémiai vizsgálatok nagyon fontosak a formin/mikrotubulus kapcsolat jobb megértésében. Számos forminról ismert (mDia1, mDia2, Formin-1b, INF1, Cappuccino, dDAAM), hogy in vitro képes a mikrotubulusokhoz kötődni [22, 125-129]. In vitro koszedimentációs tesztekben az mDia1, az mDia2, a Cappuccino és a dDAAM FH2 doménjei képesek a mikrotubulushoz kötődni [22, 125, 127, 129]. Mivel ez a domén a legkonzerváltabb a forminok között [45], ezért valószínűleg az összes formin képes kötni a mikrotubulusokat az FH2 doménen keresztül . A DRF forminok közé nem sorolható INF, eltérően a többi formintól, az FH2 doménen kívül az extrém C-terminális fehérjerészen saját mikrotubuluskötő doménnal rendelkezik [128]. Hideg kezeléssel és hígítással indukálható in vitro depolimerizációs tesztekben vizsgálható a formin/mikrotubulus interakció mikrotubulus dinamikára gyakorolt hatása. Az mDia1 és az mDia2 FH1-FH2 doménjei megóvják a mikrotubulusokat a hideg és hígítás indukálta depolimerizációtól. Valószínüleg a forminok a mikrotubulusok oldalához való kötődése megakadályozza, hogy a tubulin heterodimerek leváljanak a mikrotubulusvégekről (Bartolini és Gundersen nem közölt megfigyelései). A MAP1B és a tau fehérjékhez hasonlóan a formin/mikrotubulus kapcsolat elösegítheti a mikrotubulus növekedését [124]. Ezek után felmerül a kérdés, hogy az FH2 domén aktin- és mikrotubuluskötő funkciója hogyan befolyásolja egymás müködését és annak milyen következménye van. Az mDia2 esetében, in vivo és in vitro egyaránt, az FH2 domén dimerizációs és aktin nukleációs aktivitása független a mikrotubulus stabilizáló aktivitásától $[\underline{127}, \underline{130}]$. Ez az eredmény azt sugallja, hogy az FH2 doménen belül az aktin és mikrotubuluskötő felszín elválasztható egymástól. Továbbá az is érdekes, hogy az mDia1 és mDia2 aktin összeszerelő aktivitása jelentős mértékben lecsökken 
mikrotubulusok jelenlétében, [131] illetve a Capuccino és a dDAAM in vitro képes keresztkötni az aktin filamentumokat és a mikrotubulusokat $[\underline{22}, \underline{129}]$. A fenti megfigyelések alapján úgy tünik, hogy a forminok fontos szerepet játszhatnak a koordinált aktin-mikrotubulus hálózatok kialakításában. Ezt a feltételezést megerősíti, hogy a +TIP komplex tagjainak (APC, EB1, CLIP-170) együttmüködése az mDia1 forminnal lehetővé teszi, hogy a mikrotubulus $(+)$ vég lokálisan elösegítse az aktin polimerizációt [127, 132-135].

\section{A DAAM formin alcsalád jellemzése és kapcsolata a Wnt jelátviteli utakkal}

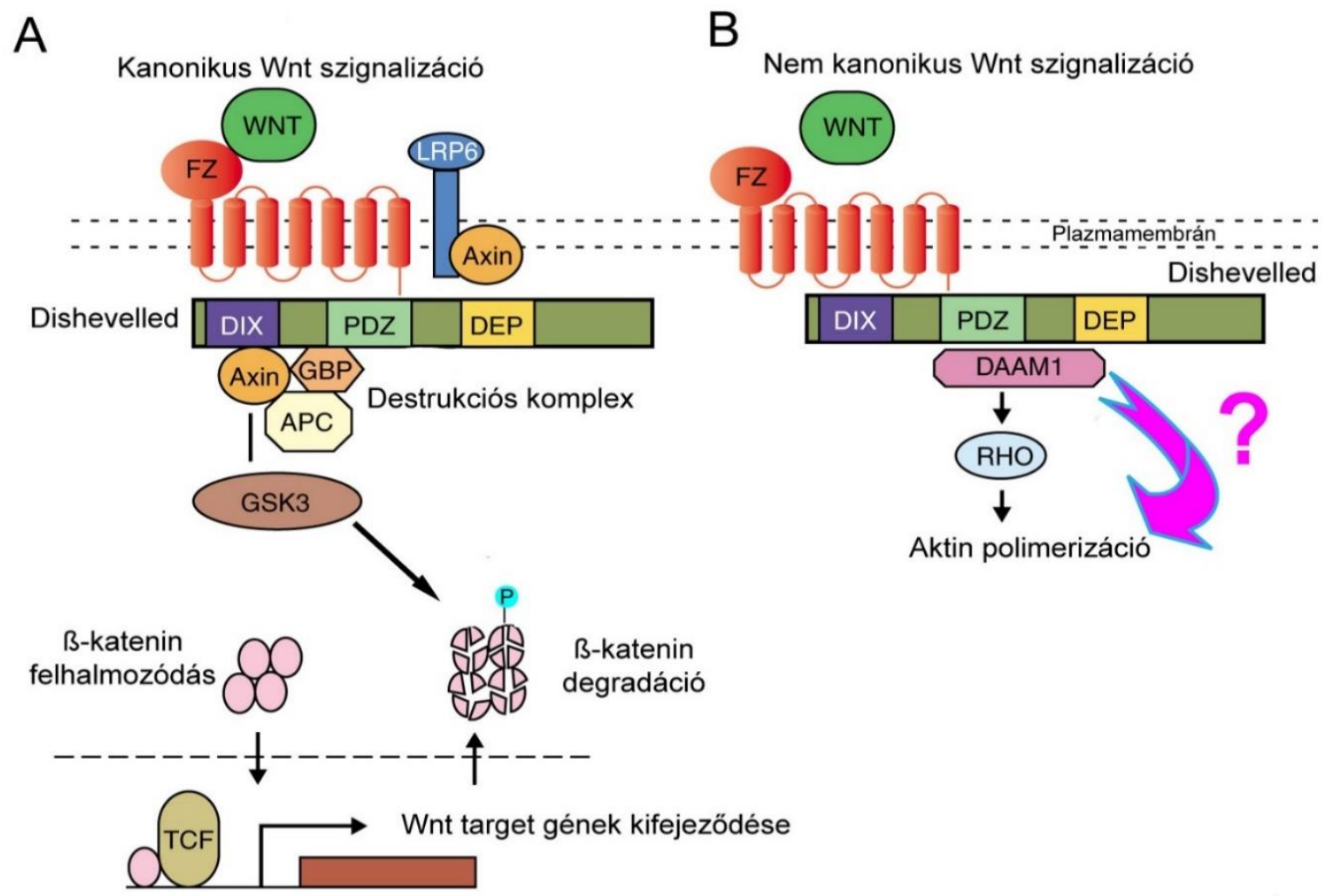

13. ábra A kanonikus és nem kanonikus Wnt jelátviteli útvonalak múködési modellje. (A) A kanonikus Wnt szignalizációban a Wnt/Wg kötődése a Fz receptorhoz és ko-receptorához az LRP5/6-hoz aktiválja a Dishevelled (Dsh) fehérjét, ami gátolja a destrukciós komplexet (Axin, APC, GBP, Gsk3- $\beta$ ). Wnt hiányában a destrukciós komplex egyik tagja a Gsk3- $\beta$ foszforilálja a $\beta$-katenint, ami annak lebontásához vezet. Ezzel szemben a Wnt molekula bekötődésével a Dsh aktiválódik, ami a destrukciós komplex szétesését eredményezi. A destrukciós komplex hiányában a $\beta$-katenin feldúsul, és a sejtmagba kerül, ahol Wnt target géneket aktivál. (B) A nem kanonikus Wnt vagy Wnt/PCP jelátviteli út két lényeges elemben különbözik a kanonikus úttól. Egyrészt a Fz receptornak nincsen ko-receptora, másrészt a nem kanonikus út $\beta$-katenin független. A Wnt molekula a Fz receptorhoz való kötődése aktiválja a Dsh-t, ami a DAAM1 formin aktivációjához vezet. Az aktiválódott DAAM1 a Rho GTPázon keresztül elősegíti az aktin filamentumok összeszerelődését. Egy másik talán valószínűbb modell szerint a Dsh és a Rho együttesen aktiválja a DAAM1-et, ami katalizálja az F-aktin képződést. Az ábra a [145]ös publikáció alapján módosítva. 
A DAAM formin alcsalád elsőként azonosított tagját majdnem 20 évvel ezelőtt írták le először egy élesztő kéthibrid kísérletsorozat eredményeképpen, mint a Dishevelled2 (Dsh2) fehérje PDZ doménjével kölcsönható partnert [136]. Ezt a kapcsolatot ko-immunoprecipitációs vizsgálatokkal is megerősítették. Az egér Dsh2 PDZ és DEP doménjei egyaránt kölcsönhatást mutatnak a teljes hosszúságú humán DAAM1-el (hDAAM1) és annak C-terminális régiójával (C-hDAAM1) is [136]. Az mDsh2 PDZ és DEP doménjeinek kitüntetett szerepe van a nem kanonikus Wnt vagy más néven Wnt/PCP (planar cell polarity) jelátviteli útvonalban (13. ábra). Később több közlemény is megerősítette a DAAM forminnak ezt a szerepét, azonban a fehérjének a müködés módjáról ellentmondásos eredmények jelentek meg az irodalomban [137-140]. A DAAM-ot először egy olyan jelátviteli komponensként írtak le, amely a Rho kisGTPáz aktivációján keresztül elősegíti az aktin filamentumok képződését [136]. Ez a feltételezés azonban ellentmond a DRF forminokra jellemző müködési mechanizmusnak, vagyis a DRF forminok aktiválódásához szükség van egy kis molekulasúlyú GTPáz bekötődésére a fehérje N-terminális felén [44]. Más vizsgálatok alapján a hDAAM1 csak a RhoA aktivált formáját képes kötni, ami szintén arra utal, hogy a kis GTPáz bekötődése szükséges a DAAM aktivációjához [141], nem pedig a DAAM aktiválja a RhoA-t. Ettől függetlenül az emlős DAAM fehérjéknek a nem kanonikus Wnt jelátviteli útvonalban betöltött szerepe biztosnak tünik, mivel erre vonatkozólag több egymástól független kísérletes bizonyíték is van.

A funkcionális vizsgálatok mellett a DAAM ortológok expressziós mintázata is ismertté vált számos gerinces fajban. Rágcsálókon végzett kísérletek alapján a fehérje nagy mennyiségben kifejeződik a fejlődő szív területén és a $D A A M 1$ mutáns egerek nagyon súlyos szívfejlődési rendellenességeket mutatnak [142]. A Xenopus, csirke és egér modell szervezeteken végzett vizsgálatok alapján a gerinces DAAM1 gének másik nagyon fontos kifejeződési területe a fejlődő KIR [143]. Emellett az is kiderült, hogy a csirke DAAM2 fontos szerepet játszik a gerincvelő fejlődése során. Ebben a munkában azt is megállapították, hogy a csirke DAAM2 az LRP 5/6 komplex-szel együtt a kanonikus Wnt-jelátviteli útvonalon keresztül fejti ki hatását [144], azonban funkciója itt is a Dsh fehérjéhez köthető, ami a kanonikus és nem kanonikus Wnt jelátviteli utak közös komponense (13. ábra) [145]. 


\section{A kémiai szinapszis általános felépítése és múködése}

A szinapszisoknak alapvetően két fajtája létezik: kémiai és elektromos. Mivel a legtöbb adat a kémiai szinapszisokra vonatkozik a sejtvázszabályozást illetően, ezért a dolgozatban csak a kémiai szinapszisokkal foglalkozom. A szinapszisok intercelluláris kapcsolatok a preszinaptikus neuron és a posztszinaptikus sejt között. Az információ akciós potenciál (AP) formájában érkezik a preszinaptikus végződésre és kémiai jelátvivő anyag formájában adódik át a posztszinaptikus félre. A preszinaptikus végződésben a jelátvivő anyagok szinaptikus vezikulákba (SV) csomagolódnak. Amikor az AP kinyitja a feszültségfüggő $\mathrm{Ca}^{2+}$ csatornákat, akkor a jelátvivő anyagok, mint pl: a glutamát vagy az acetil-kolin (ACh) SV exocitózissal felszabadulnak a szinaptikus résbe, ahol aktiválják a posztszinaptikus denzitás által körülhatárolt receptorokat. Az SV exocitózis legnagyobb részt a preszinaptikus plazmamembrán egy kis részén történik, ahol egy elektrodenz fehérjekomplex található, amit aktív zónának nevezünk (14. ábra).

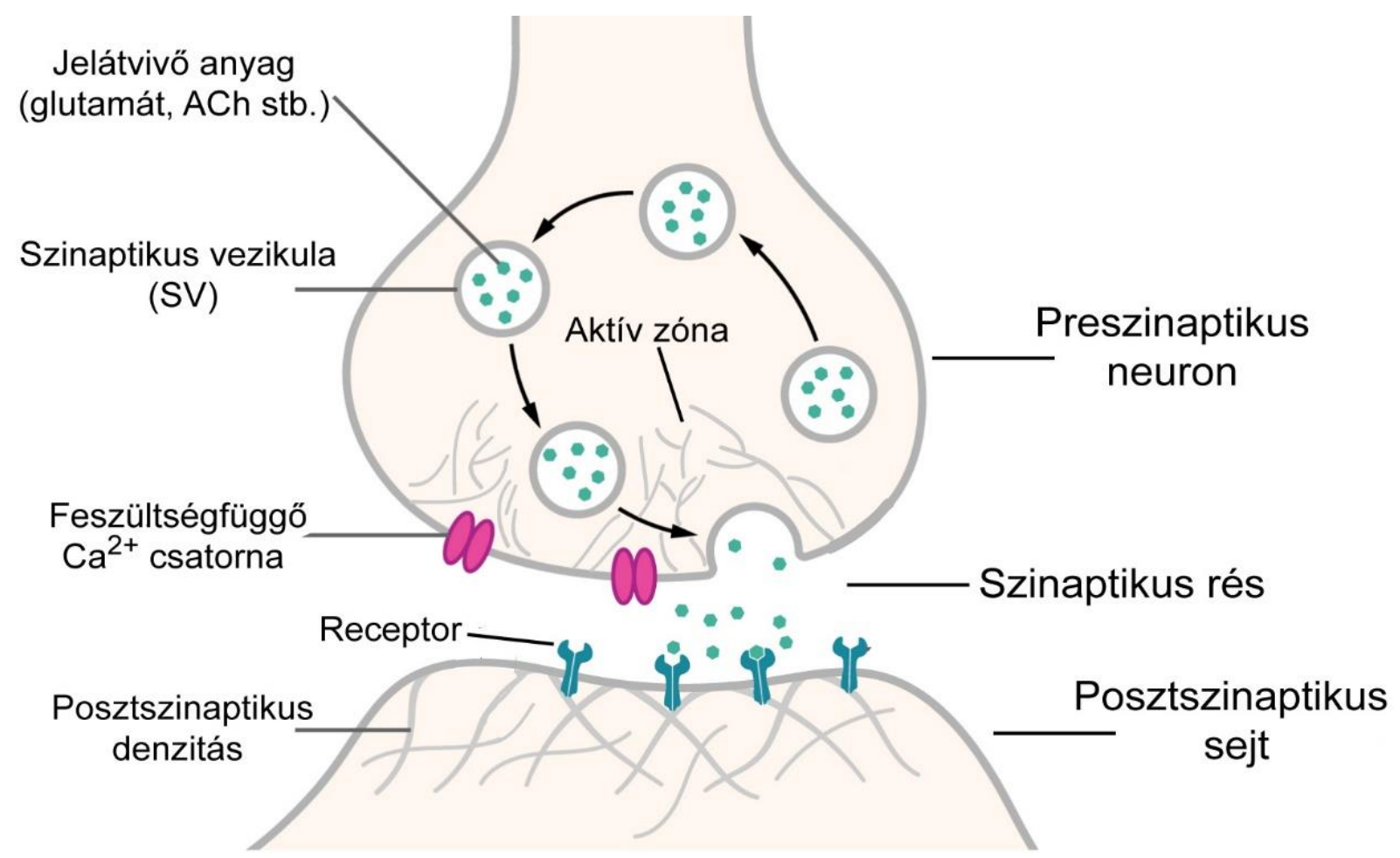

14. ábra A kémiai szinapszis felépítése és működése. Az ábra a www.scistyle.com webhelyről letöltve és módosítva. 


\section{A Drosophila NMJ, mint szinaptikus modellrendszer}

Az ecetmuslica idegrendszerének a fejlődése során milliónyi szinaptikus kapcsolat alakul ki, amely az életben maradás elengedhetetlen feltétele. A szinaptikus kapcsolatok létrejöttéhez rendkívül bonyolult folyamatok összességére van szükség. Első lépésben az axon végződés környezeti jelek alapján megkeresi a célsejtjét, ahol annak növekedési kúpja morfológiai változásokon megy keresztül és kialakul a szinapszis. A szinapszisok stabilizálódása közben kialakulnak a preszinaptikus aktív zónák, ahol a neurotranszmitter molekulák felszabadulása történik. Mind az axon navigálás, mind a szinaptikus stabilizálódás során az aktin és mikrotubulus sejtváz dinamikus átrendeződése figyelhető meg. A szinaptikus fejlődés tanulmányozására használt legsokoldalúbb és ezért legnépszerübb kísérleti modellrendszer Drosophilában az ideg-izom vagy neuromuszkuláris kapcsolat (NMJ) [147].

A Drosophila NMJ-t az 1970-es években kezdték el vizsgálni [148, 149], majd a 80-as és 90-es években vált népszerü eszközévé a szinaptikus folyamatok tanulmányozásának [150]. Egyik legelőnyösebb tulajdonsága a Drosophila NMJ-nek, hogy megfelelően nagyméretü struktúra ahhoz, hogy a szinaptikus fejlődés legfontosabb szakaszait, például a sejtvázátrendeződéseket megfigyeljük. Mindamellett az NMJ-ket egyedi mintázatuk alapján könnyü azonosítani, és elektrofiziológiai méréseket is tudunk rajtuk végezni. A Drosophila NMJ, hasonlóan a gerincesekhez, serkentő kémiai szinapszis, viszont a gerincesekétől eltérően az ingerületátvivő anyag a glutamát és nem az ACh. A posztszinaptikus oldalon ionotróp glutamát receptorok (GluR) találhatóak, amelyek nagyfokú homológiát mutatnak az emlős agy AMPAtípusú glutamát receptoraival. A fent említett tulajdonságai miatt a Drosophila NMJ kiváló kísérleti eszköz a szinaptikus fejlődés tanulmányozására [151-155].

Az embrionális Drosophila NMJ kialakulása és fejlödése

A Drosophila NMJ rendszer a KIR részét képező motoraxonok és a testfalhoz tapadó izmok kapcsolódásainak, vagyis szinapszisainak az összességét jelenti. Ahhoz, hogy ez a jól felépített, szervezett struktúra létrejöjjön, a KIR-ből kiinduló axonoknak meg kell találniuk a célsejtjeiket. Ezt a folyamatot axon navigálásnak hívjuk, ami az embrionális fejlődés során megy végbe [156-159]. Embrióban a KIR-ből kilépő motoraxonokat 6 különböző csoportba sorolhatjuk a perifériás elágazási mintájuk alapján: interszegmentális (ISN, ISNb, ISNd), szegmentális ( $\mathrm{SNa}$ és $\mathrm{SNc}$ ) és transzverzális (TN). Az interszegmentális idegek túlnyomó 
többsége a következő poszterior szegmentet idegzik be, míg a szegmentális idegek ugyanabban a szegmensben találhatóak, mint a célsejtjeik (15. ábra) [156-160].

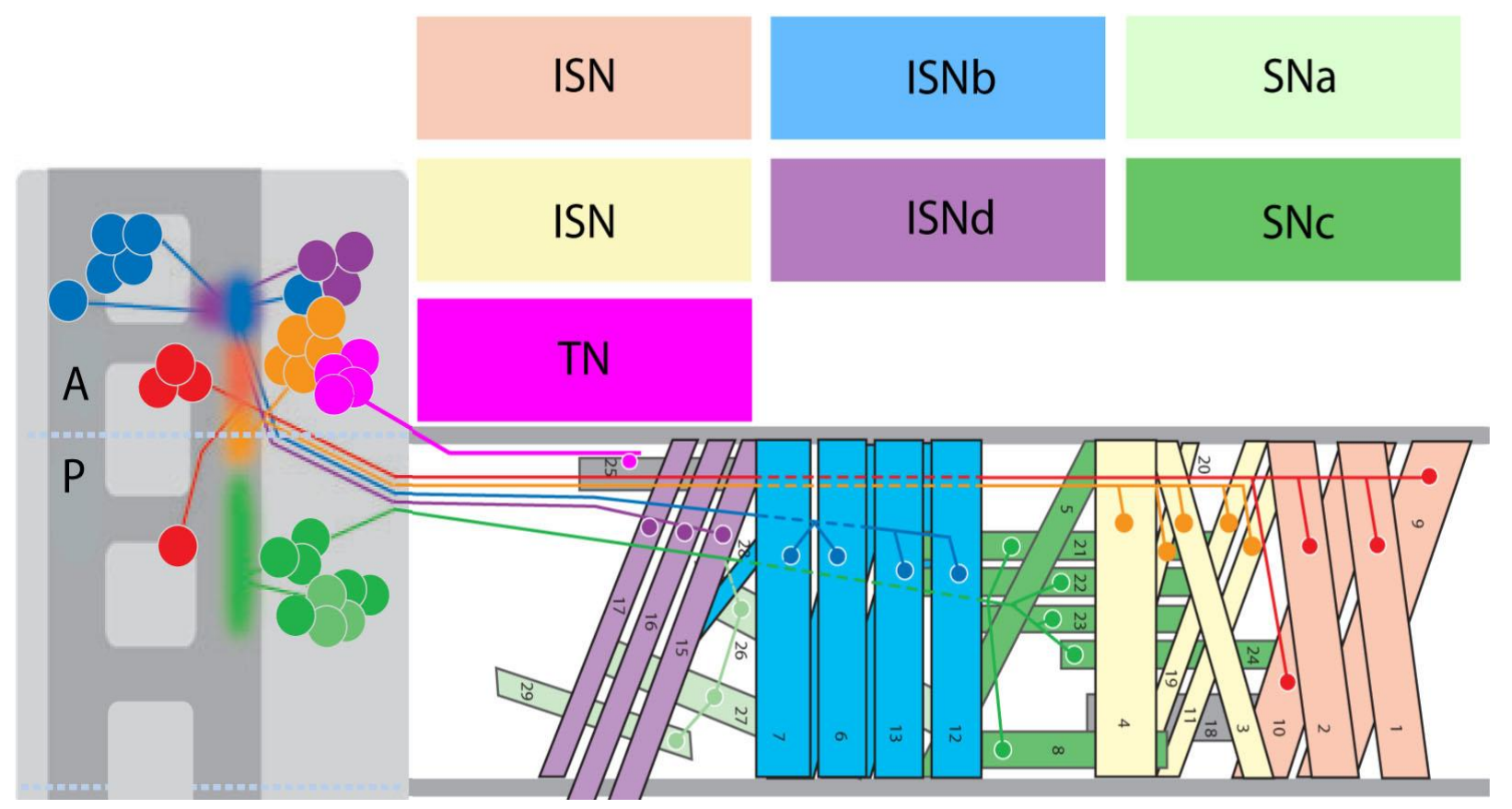

15. ábra Az embrionális neuromuszkuláris rendszer felépítése. A ventrális idegkötegből kilépő motorneuronok többsége (ISN, ISNb, ISNd, TN) a target sejtjeikhez képest egy szegmenttel anterior irányba helyezkednek el, míg a szegmentális motorneuronok ( $\mathrm{SNa}, \mathrm{SNc}$ ) sejttestei és végződései ugyanabban a szegmentben találhatóak. Az ábra a [156]-os publikáció alapján módosítva.

Nagyon fontos, hogy a motoraxon a neki megfelelö elágazási mintát vegye fel, mert enélkül nem képes megtalálni a célsejtjét. A motoraxonok perifériás elágazási mintája genetikailag determinált, számos gént, illetve fehérjét ismerünk, amelyek képesek meghatározni az axon elágazási pontoknál a növekedés irányát. Például az Eve transzkripciós faktor szükséges és elégséges az ISN ideg dorzális elágazásához [161].

A motoraxonok a növekedési kúpukon filopódiumokat növesztenek a célsejtjeiknek a keresése során, amelyek képesek csápszerü képletekként letapogatni a környezetüket. Ehhez hasonlóan az izmok is filopódiumokat növesztenek (miopódium), amelyek több axon végződéssel is kapcsolatba kerülhetnek (16. ábra) [162, 163]. 
A

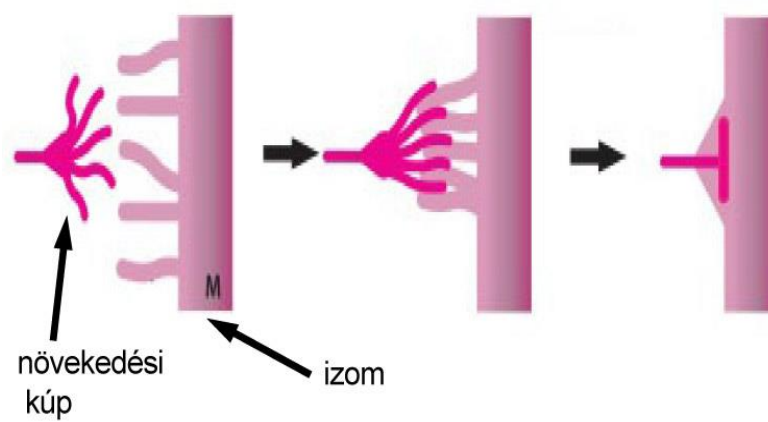

B

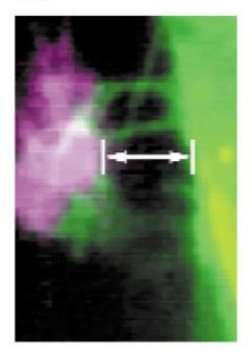

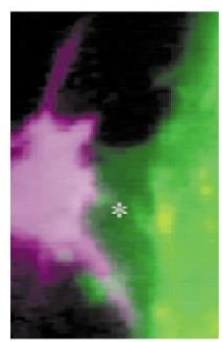

16. ábra A neuronális filopódium és a posztszinaptikus miopódium kapcsolódása (A) A szinapszisok stabilizálódásának sematikus ábrázolása. (B) Az ISNb axon végződés filopódiumai (magenta) elérik a posztszinaptikus izomsejt miopódiumaiat (zöld) majd összekapcsolódnak és létrejön a szinaptikus kapcsolat. Az ábra a [162]-es publikáció alapján módosítva.

A partner felismerési folyamat kölcsönös, mind a pre- mind a posztszinaptikus oldalon folyik a keresés [163]. Az egymásra találást a pre- és posztszinaptikus filopódiumokon található transzmembrán, ún. sejtadhéziós fehérjék (CAM, cell adhesion protein) segítik elő. Ha megtörtént a felismerés, a két oldal sejtadhéziós fehérjéi összekapcsolódnak, amit transzszinaptikus kapcsolatnak nevezünk. Számos, a sejtadhéziós molekulák között létrejövő transzszinaptikus kapcsolatot ismerünk, ezek közül a legismertebb a neurexin-neuroligin kettős $[\underline{160}, \underline{164]}$.

Az embrionális fejlődés végére (13-15. stádium) a célsejtek keresése befejeződik és a létrejött neuromuszkuláris rendszer felépítése kisebb módosulásokkal megőrződik egészen a lárvális fejlődés végéig. A Drosophila embrió 8 abdominális szegmentjéből 6-ban (A2-A7) megfigyelhetö, hogy minden egyes hemiszegmentben körülbelül 40 motoraxon sztereotíp módon innervál 30 egyedi izmot (15. ábra). Ennek következtében az egyedi NMJ-k könnyen azonosíthatóak, mivel a motoraxon hálózat felépítése és az izmok elhelyezkedése jellegzetes mintázatot vesz fel [156-160].

Miután létrejött a transzszinaptikus kapcsolat, a posztszinaptikus oldalon a GluR és a Disc large (Dlg) fehérjék kifejeződése jelentős mértékben megnő. A Dlg (PSD-95 fehérje emlős homológja) nagyon fontos eleme a posztszinaptikus oldalnak, ahol képes elősegíteni más fehérjék kihorgonyzását, mint például a GluR-t. A Dlg fehérje jelenlétével elkezdődik a GluR klaszterek kialakulása. A GluR klaszterek kialakulásával párhuzamosan a preszinaptikus oldalon lévő növekedési kúp stabilizálódik és létrejön a preszinaptikus végződés. A preszinaptikus végben eközben jelentős strukturális változások történnek, a posztszinaptikus GluR klaszterekkel szemben kialakulnak a preszinaptikus aktív zónák, amelyek kerek vagy 
ovális ún. szinaptikus boutonokban helyezkednek el. Az embrionális fejlődés végére néhány szinaptikus bouton jön létre az axon terminálison $[\underline{165}, \underline{166}]$.

\section{A lárvális Drosophila NMJ fejlödése}

A lárvális fejlődés egyik nagyon fontos jellemzője, hogy megfelelő táplálék jelenlétében az állat testmérete jelentősen megnő, így az izmok is. Az embrióból kikelő első stádiumos lárva testfal izmának a felszíne körülbelül százszor nagyobb lesz a lárvális fejlődés végére. Az izom növekedése során az NMJ mérete is nő, azáltal, hogy új boutonok képződnek az izmok felszínén.

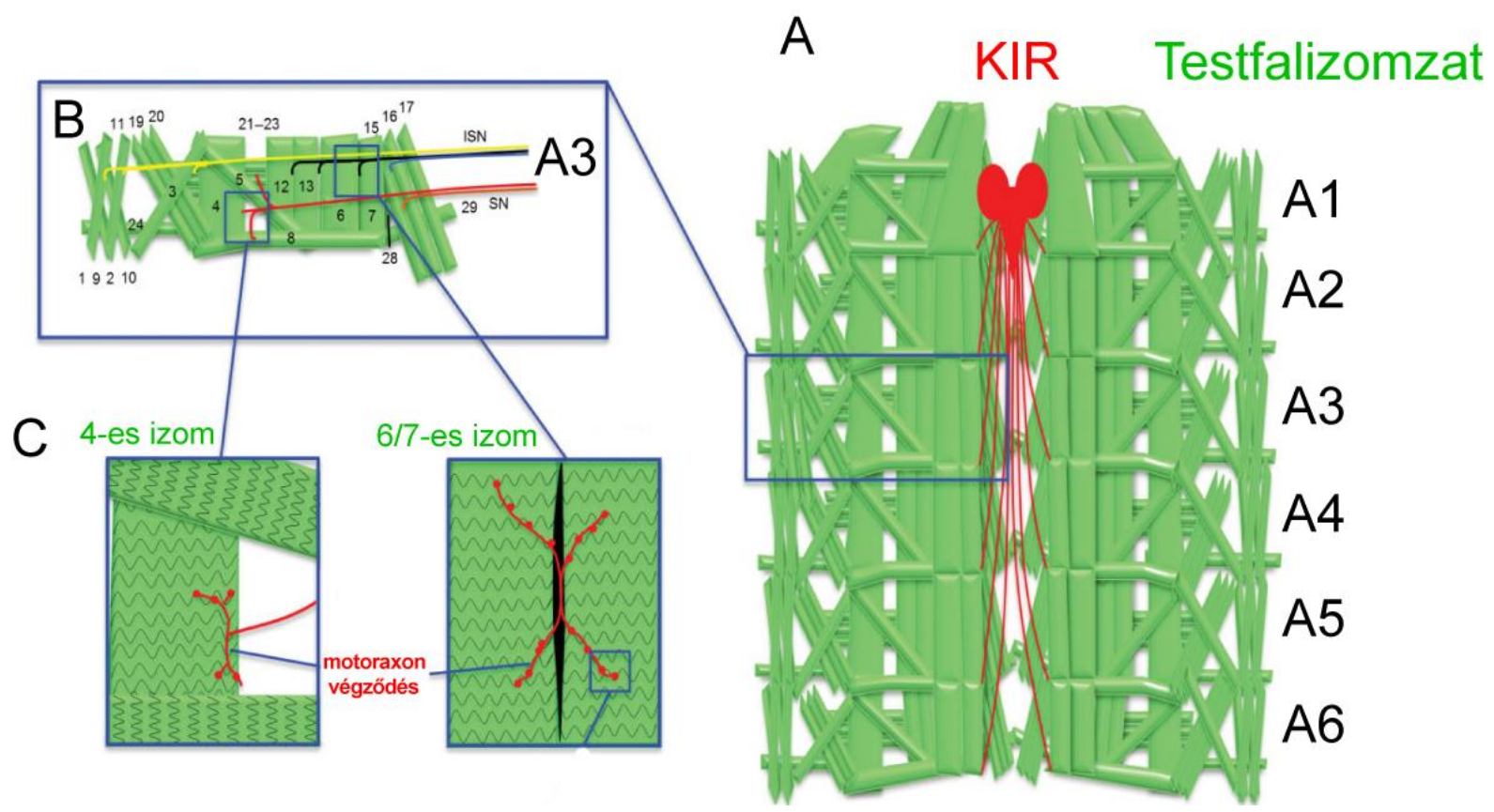

17. ábra A lárvális NMJ anatómiája. (A) A Drosophila lárvális NMJ rendszer felépítése az A1-A6 szegmentig bezárólag (a 7. abdominális szegment nincs feltüntetve az ábrán). A Drosophila motoros rendszer minden egyes hemiszegmentben 30 egyedi izomból (zöld) és az azokat beidegző körülbelül 40 motorneuronból (piros) épül fel. Az A1 szegmentet kivéve, az A2-A7 a testfalizmoknak minden egyes hemiszegmentben sztereotíp mintázata van. (B) A KIR-ből (központi idegrendszer) kilépő motoridegek két legnagyobb csoportja a szegmentális (SN, piros) és az interszegmentális (ISN, sárga, fekete, kék) idegek az izmok területén (zöld) több elágazási pontot létrehozva kialakítják az NMJ-ket. (C) Az ISNb motoraxon a 6/7 izmot, míg az SNa ideg a 4-es izmot idegzi be, amelyek a legnépszerúbb vizsgálati objektumai a szinaptikus fejlődés tanulmányozásának. A motoraxon végződés (piros) az izomnak a felszínén (zöld) szinaptikus boutonokat hoz létre, amelyek száma a lárvális fejlődés során folyamatosan növekszik. Az ábra a [157]-es publikáció alapján módosítva.

A boutonok képződésével párhuzamosan az aktív zónák száma is emelkedik a boutonon belül. Az új boutonok képződése valamint a boutonon belüli aktív zóna szám emelkedés, azt eredményezi, hogy egy adott NMJ-n belül a lárvális fejlődés során nagyjából százszorosára 
emelkedik az egyedi aktív zónák száma, ami hatékonyabb ingerületátvitelt tesz lehetővé a megnövekedett testfalizmon [167-169]. A lárvális NMJ presznaptikus idegvégződése az izom felszínén elágazik, ahol létrehozza a gyöngyfüzérszerüen elhelyezkedő szinaptikus boutonok láncolatát. Megfigyelhető, hogy a különböző hemiszegmentekben ugyanazon izmokhoz tartozó NMJ-knek hasonló mintázata és kiterjedése van. Például a 3. stádiumos vándorló lárvában a 4es izomhoz tartozó NMJ az A2-A7 hemiszegmentekben rendszerint Y alakú elágazási mintát vesz fel és körülbelül 20-25 szinaptikus boutont alakít ki az izom felszínén (17. ábra). Ez a sztereotíp tulajdonsága lehetővé teszi, hogy a Drosophila genetika széles tárházát felhasználva megvizsgáljuk milyen gének, hogyan befolyásolják a szinaptikus fejlődés folyamatait [147, $\underline{157}, \underline{158}, \underline{170}, \underline{171]}$.

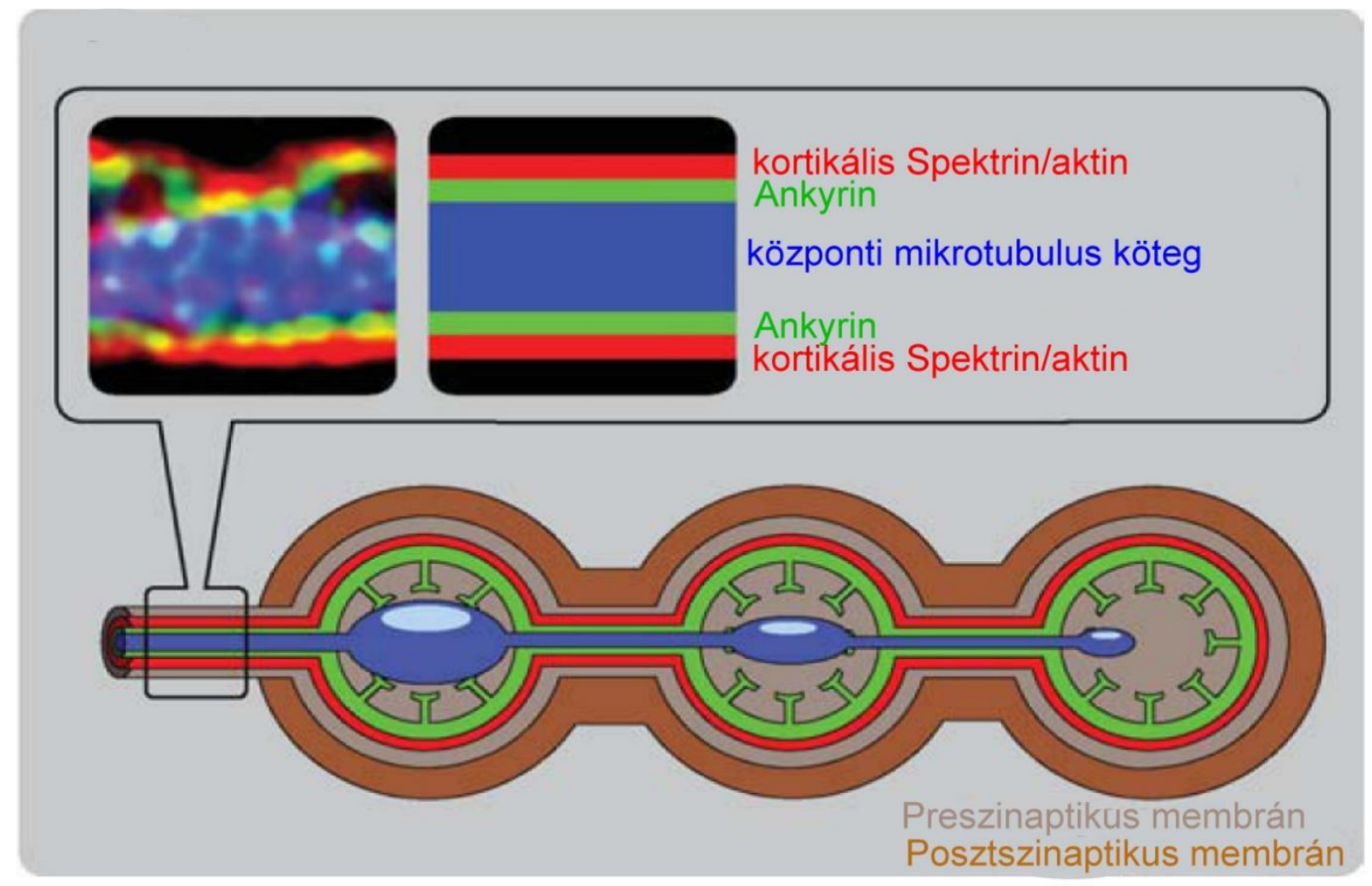

18. ábra A Drosphila NMJ sejtváz felépítésének sematikus ábrázolása. Az alsó panelen lévő 3 terminális bouton rendelkezik egy pre- és egy posztszinaptikus oldallal. A preszinaptikus oldal sejtváz komponensei alapján 3 fö strukturális egységre osztható: a preszinaptikus membránt körülvevő kortikális Spektrin/aktin hálózat (piros), az NMJ központi mikrotubulus kötege (kék) valamint a kortikális aktin és központi mikrotubulus köteget összekötő Ankyrin hálózat (zöld). Az ábra a [176]-os publikáció alapján módosítva.

Ahhoz, hogy létrejöjöjjön az NMJ az izom felszínén a sejtváz összehangolt, dinamikus átrendeződésére van szükség. Sejtvázszerveződés szempontjából lényeges különbségek figyelhetőek meg a preszinaptikus és posztszinaptikus oldalak között (18. ábra). Az érett 
nagyméretü bouton $(2-3 \mu \mathrm{m})$ esetében a posztszinaptikus oldal bonyolult membránrendszert (subsynaptic reticulum, SSR) hoz létre [172]. Ez a struktúra a lárvális fejlődés során lassan, fokozatosan alakul ki. Az újonnan kialakult szinaptikus bouton még csak egy membrán réteggel rendelkezik, majd később betürődések alakulnak ki rajta. Ennek eredményeképpen a szinaptikus boutont egy több rétegü, nagy felszínnel rendelkező komplex membránrendszer veszi körül [172]. Az SSR funkciója pontosan nem ismert, egyesek szerint fenntarthatja a szinaptikus fejlődésben fontos fehérjék magas koncentrációját, mások szerint elősegítheti a molekulák gyors transzportját [173]. Az SSR egy elektrodenz, fehérjében gazdag struktúra, amelynek eddig két fontos szerkezeti egységét ismerjük. Az egyik a Dlg vázfehérje, amely az SSR membránjában található és fontos szerepe van a GluR klaszterek toborzásában [ $\underline{165}, \underline{166}]$. A másik a Spektrin/aktin hálózat, amely többek között a Dlg fehérjék kihorgonyzásában vesz részt [174-176]. Ezzel szemben, a preszinaptikus oldal 3 szerkezeti egységre osztható. Ezek: a preszinaptikus membránt körülvevő kortikális Spektrin/aktin hálózat, az NMJ központi mikrotubulus kötege valamint a kortikális aktin és a központi mikrotubulus köteget összekötő Ankyrin hálózat (18. ábra) [177]. A preszinaptikus oldalon fontos megemlíteni még a preszinaptikus aktív zónát. Elektronmikroszkópos felvételeken az aktív zóna egy elektrodenz T alakú struktúrát (T-bar) vesz fel, amelynek proximális része a preszinaptikus membránhoz rögzül, míg a disztális oldal kiszélesedik és számos SV veszi körül [146, 178-181]. Ma már tudjuk, hogy ennek az elektrodenz, fehérjében gazdag struktúrának egyik nagyon fontos vázeleme a Brp. A Brp egy hosszúkás, filamentáris fehérje, amelynek hiányában nem képződnek funkcionális aktív zónák. A nagy felbontású STED (super-resolution stimulated emission depleted) mikroszkópiának köszönhetően ma már ismert, hogy a Brp N-terminális része az aktív zóna proximális részén a preszinaptikus membránban lévő $\mathrm{Ca}^{2+}$ csatornához rögzül (19. ábra $\mathrm{B}, \mathrm{C}$ ), míg a Brp C-terminális része az aktív zóna disztális kiszélesedő részén található (19. ábra A, C). A megfigyelések alapján úgy tűnik, hogy az elektrodenz T-bar egyik fö komponense a Brp lehet [182-185]. A Brp-n kívül még a Syd-1 és a Liprin- $\alpha$ (Syd-2) is fontos elemei az aktív zóna összeszerelődésnek [186-188] 

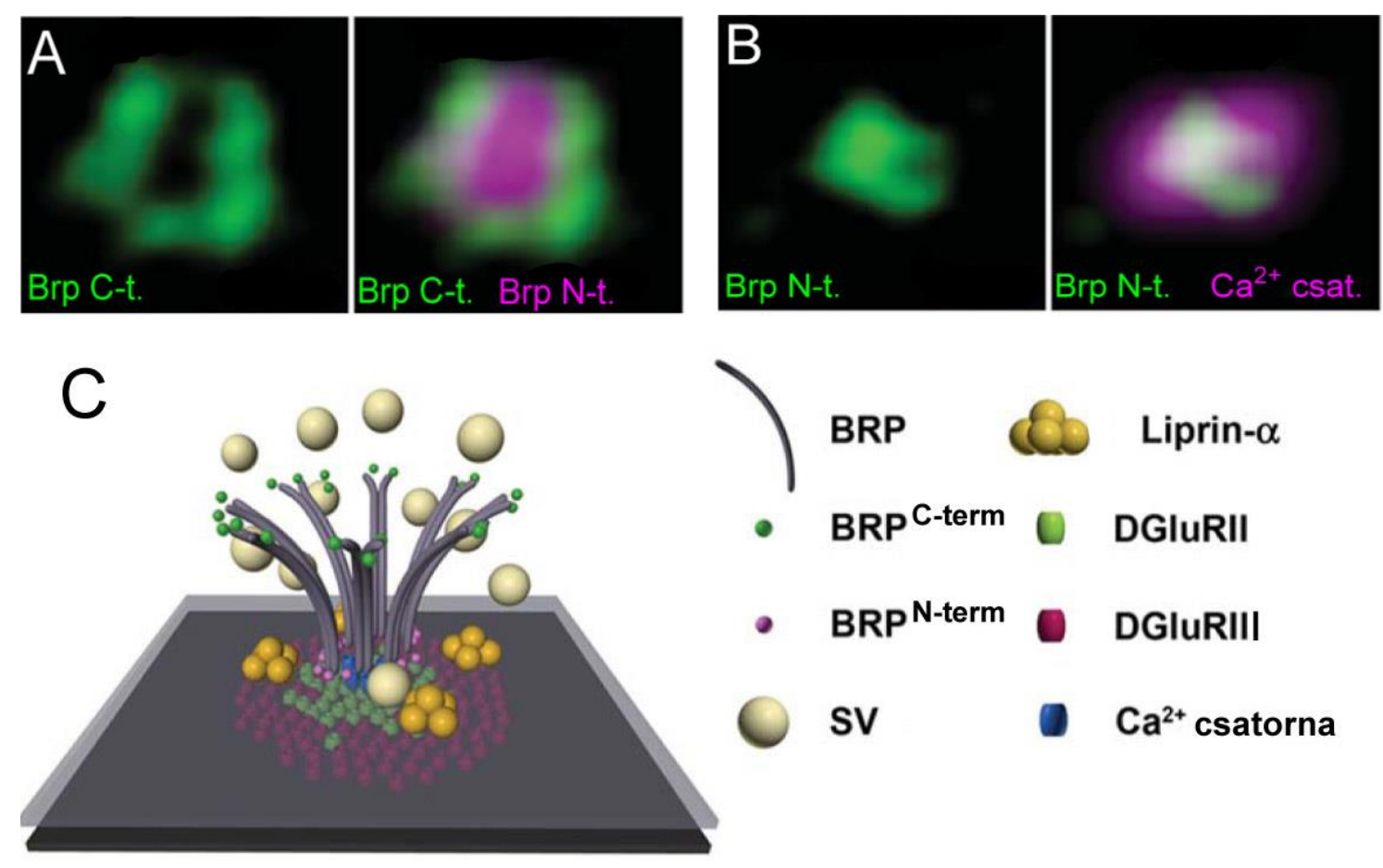

19. ábra A Drosophila preszinaptikus aktív zóna felépítése. (A) A STED mikroszkópos képeken az aktív zóna szerveződésének a vizsgálata látható anti-Brp C-term (zöld) és anti-Brp N-term (magenta) ellenanyagok használatával. A felülnézeti képeken a Brp C-term mintázata körülöleli a Brp N-term jelet. (B) A STED mikroszkópos felvételeken az aktív zóna szerveződésének a vizsgálata látható anti-Brp Cterm és anti- $\mathrm{Ca}^{2+}$ csatorna ellenanyagok használatával. $\mathrm{A} \mathrm{Ca}^{2+}$ csatorna lokalizációja szinte teljesen átfed az anti-Brp N-term immunfestéssel (C) Az aktív zóna szerveződésének a sematikus modellje. Az aktív zónák összeszerelődésében a Brp és a Liprin- $\alpha$ egyaránt kulcsfontosságú. A filamentáris szerkezetű Brp $\mathrm{N}$-terminális része a preszinaptikus membránnál található $\mathrm{Ca}^{2+}$ csatornához rögzül, míg a fehérje $\mathrm{C}$ terminális része az aktív zóna disztális részén elősegíti az SV-k toborzását. Az aktív zónával szemközt a posztszinaptikus oldalon a GluR (GluRII, GluRIII) komplex található. Az ábra a [184]-es publikáció alapján módosítva.

\section{Az aktin sejtváz szerepe és szabályozása a szinaptikus fejlődés során}

Miután az axon végződés megtalálta a megfelelö célsejtet, az axon növekedési kúpja arborizációt hoz létre a célsejten, ami általában megelőzi a szinaptikus fejlődést. Az axonális arborizáció rövid, elágazó struktúrák összessége, amelyeken találhatóak a boutonok és az azokon lévő szinapszisok [189]. Mivel az axon arborizáció létrehozása és a szinaptikus fejlődés térben és időben nagyon közel történik, úgy gondoljuk a sejtek számos elemében ugyanazokat a sejtvázszabályozási mechanizmusokat használják ezekben a folyamatokban [190, 191]. Irodalmi adatok alapján a preszinaptikus aktin sejtváznak fontos szerepe lehet a szinaptikus kapcsolatok létrehozásában, ugyanis latrunculin-A (aktin depolimerizáló szer) kezelés hatására 
fejlődő szinapszisokban a preszinaptikus összeszerelődés súlyosan érintett, ami egyben a szinapszisok számának csökkenését is okozza [192, 193].

Az aktin nukleátorok katalizálják az aktin filamentumok gyors összeszerelődését [모, $\underline{9}$, amelyek elméletileg elősegíthetik a terminális arborizáció struktúráinak létrejöttét. Emlősökben két aktin nukleátort ismerünk, amely részt vesz ezekben a folyamatokban. Az egyik a Cobl [34], amely a nem elágazó aktin filamentumok kialakításáért felelős, míg a másik az Arp2/3 komplex [194], amely eltérően a Cobl fehérjétől az elágazó aktin struktúrákat hoz létre. Az aktin nukleáció nem minden esetben segíti elő a terminális arborizációt, ugyanis az Arp2/3 komplex képes azt gátolni is. Az Arp2/3 aktivitása nagymértékben függ az ő aktivátoraitól (NPF), mint pl a WASP fehérje. Az NPF fehérjék a plazmamembránhoz lokalizálódnak és a Syndapinok képesek ott aktiválni őket. Ha az Arp2/3 elősegítené a terminális arborizációt, akkor azt várnánk, hogy a Syndapin hiánya kevesebb boutont eredményezne, pedig ennek pont az ellenkezője történik [195]. Ezek alapján úgy tünik, hogy az aktin nukleációs faktorok paradox módon képesek elősegíteni és gátolni is a terminális arborizációt celluláris kontextustól függően. Valószínüleg ebben az esetben az elágazó aktin filamentumok visszatartják a mikrotubulusok növekedését, így kevesebb terminális ág jön létre az axon végződésen [194, 195]. Drosophilában eddig két aktin nukleációs faktorról (Dia, Arp2/3) tudjuk, hogy szerepet játszik az NMJ terminális kialakulásában. A Dia [196] és az Arp2/3 [197] hiányában boutonok számának a csökkenése és abnormális aktin szerveződés figyelhető meg, ami arra utal, hogy a fehérjék aktin nukleációs aktivitása szükséges a boutonok képződésében. Fontos megemlíteni még a kortikális Spektrin/aktin hálózatot. A legtöbb sejtben a kortikális membrán aktin sejtváz heterotetramer $\alpha$ - és $\beta$-Spektrin molekulákból áll, amelyeket rövid aktin filamentumok kötnek össze. A fejlődő Drosophila idegrendszerben mindkét Spektrin kifejeződik és a fehérjék hiányában súlyos NMJ fejlődési hibák alakulnak ki [174-176]. Ezzel összhangban, egerekben a $\beta$-SpektrinIII hiánya súlyos szinapszis képződési abnormalitásokat okoz [198, 199].

Az aktív zóna egy fehérjében gazdag struktúra, amelynek elsődleges funkciója a szinaptikus vezikulák toborzása és felszabadítása. Az aktív zóna összeszerelődés folyamatairól még elég hiányosak az ismereteink, de azt tudni lehet, hogy számos fehérje (Brp/ELKS-1, RIM, SYD-1, SYD-2/Liprin- $\alpha$, Piccolo/Fife, Bassoon) részt vesz a fehérjekomplex kialakításában [146, 200]. Azt korábban már ismertük, hogy az aktin filamentumok gyürüszerü struktúraként körbeveszik az SV-ket és az aktív zónákat patkány idegsejtekben, viszont arról nem volt ismeretünk, hogy részt vesznek-e az aktív zónák összeszerelődésében [201]. C.elegans-ban azonban bemutatták, hogy a neurabin homológ NAB-1 a szinapszisképződés során szükséges ahhoz, hogy az F-aktin hálózatot összekapcsolja a SYD2 és SYD-1 aktív zóna összeszerelő 
fehérjékkel [202]. Drosophila-ban pedig a Nwk-ról (Nervous Wreck) tudjuk, hogy irányítja az aktív zóna összeszerelődést az aktin sejtváz szabályozása által. nwk mutánsokban kevesebb aktív zóna és csökkent szinaptikus transzmisszió figyelhető meg. Az Nwk az elágazó aktin filamentumok szabályozásáért felelős, ugyanis bemutatták, hogy az Nwk a Wasp és az Arp2/3 komplex-szel direkt kölcsönhatásban van, illetve a Wasp és az Nwk erős kolokalizációt mutat egymással a preszinaptikus oldalon [203]. Ezek alapján úgy tünik, hogy az aktin az aktív zóna összeszerelődés upstream eleme. Ezzel összhangban emlős fiatal szinapszisokban a preszinaptikus F-aktin depolimerizációja az aktív zóna protein Bassoon klaszterek eltűnését okozza [192]. Érdekes, hogy az aktív zóna fehérjék is képesek befolyásolni a preszinaptikus aktin organizációt. A Piccolo emlős szinapszisokban számos aktinkötő fehérjével kölcsönhatásba kerül és platformot biztosít a térbeli aktin filamentumok kialakulásának az aktív zóna környékén. Patkány idegsejtekben az aktivált DAAM1 (formin típusú aktin nuklátor) a Piccolo-hoz kötődik, amely interakció irányítja az F-aktin összeszerelődést. DAAM1 hiányos neuronokban a preszinaptikus F-aktin szerveződés súlyosan érintett. Összességében a Piccolo által irányított folyamatok lehetőséget biztosítanak arra, hogy az aktin szerveződésben egy visszajelzési mechanizmus valósuljon meg az aktív zóna összeszerelődés során [204-206].

A posztszinaptikus oldalon lévő aktin sejtváznak is fontos szerepe van a szinapszisképződésben. Az emlősök agyában a serkentő szinapszisok többségében a posztszinaptikus oldalon dendrittüskék találhatóak, amelyek morfológiai szempontból sokszínű, aktinban gazdag struktúrák. A tüskék sejtváz szerveződésében a hatalmas elágazási rendszerrel rendelkező aktin filamentumok a dominánsak. Ezenkívül a dendrittüskékben nagymennyiségű monomerikus G-aktin is található, amely biztosítja az aktin utánpótlást a dinamikus sejtváz-átrendeződésekhez [207, 208]. Az aktin filamentumok kialakításában 3 fontos aktin összeszerelő faktort azonosítottak: az Arp2/3 komplexet, a forminokat és a profilint. Ezek közül talán a legjelentősebb az Arp2/3 komplex, amelynek szüksége van természetesen az NPF fehérjékre is, mint pl. N-Wasp, WAVE, WASH stb. Az Arp2/3 és az NPF fehérjék hiányában súlyos morfológiai változások figyelhetőek meg a dendrittüskékben [209, 210]. A forminokra is szükség van a dendrittüskékben, ugyanis a dendrittüskék felszínén kialakulhatnak filopódia-szerü nyúlványok, amelyekben párhuzamosan futó nem elágazó aktin filamentumok találhatóak [211, 212]. A profilin pedig az Arp2/3 komplex és a forminok számára biztosítja a nagymennyiségü monomerikus G-aktint a polimerizáció helyszínén [213, 214]. Drosophila-ban a posztszinaptikus rész aktin sejtvázáról és annak szabályozásáról eddig nem sokat tudunk, de az biztosnak tünik, hogy a Spektrin/aktin hálózat fontos a 
posztszinaptikus rész felépítésében $[\underline{171}, \underline{174}, \underline{175}]$, valamint szerepet játszik a Dlg-vel együtt a GluR klaszterek kialakításában [166].

\section{A mikrotubulusok szerepe és szabályozása a szinapszisok kialakulásában}

A mikrotubulusok alapvető sejtváz elemei a neuronoknak. Részt vesznek az axon növekedésben, az intracelluláris transzportban és a sejtalak fenntartásban [ $\underline{95}, \underline{215}]$. Emlősökben eddig elég keveset tudunk arról, hogy a preszinaptikus mikrotubulusoknak mi a funkciója. Drosophila-ban számos gént ismerünk, ami befolyásolja a preszinaptikus mikrotubulus szerveződést [147]. A legismertebb ezek közül a Futsch, amely az emlős MAP1B Drosophila ortológja. A MAP1B-hez hasonlóan egy mikrotubulus asszociált fehérje, amely képes a mikrotubulusokhoz kötődni. A fehérje hiányában a központi mikrotubulus köteg fragmentálódik, ami az NMJ-ben csökkent bouton számot eredményez [122, 123]. Ezek alapján valószínüleg a Futsch az NMJ-ben elősegíti a mikrotubulusok stabilizálódását. A korábban említett DRF formin a Dia is befolyásolja a mikrotubulus organizációt az NMJ-ben valószínüleg a Dlar és a Trio által szabályozott jelátviteli útvonal effektor fehérjéjeként [196]. A dia mutáns szinapszisokban a pionír mikrotubulusok $(+)$ vég dinamikája jelentős mértékben megváltozik. A Dia valószínüleg a pionír mikrotubulusok $(+)$ végét képes stabilizálni, amely elősegítheti a bouton képződést. Mivel a Dia az aktin organizációt is befolyásolja az NMJ-ben, ezért nem zárható ki annak a lehetősége, hogy a Dia a mikrotubulus $(+)$ véget stabilizáló hatása közvetett [196]. A következő fehérje a kizárólag idegrendszerben kifejeződő Ank2, amely egy óriási adaptor molekula. Az Ank2 legismertebb funkciója, hogy összeköti a kortikális Spektrin/aktin hálózatot a központi mikrotubulus köteggel. Az Ank2 hiánya súlyos problémákat okoz a mikrotubulus szerveződésben, az NMJ terminális részén a mikrotubulusok gyakran hiányoznak, míg az NMJ középső harmadában hatalmas mikrotubulus felhalmozódások figyelhetőek meg [216-218]. Végül a kanonikus Wnt szignalizáció bizonyos tagjairól is tudjuk, hogy részt vesznek a szinaptikus bouton képződésben a mikrotubulusok szabályozása által [219, 220]. A Drosophila NMJ preszinaptikus oldalán a divergens kanonikus Wnt útvonal müködik (20. ábra), ami eltérően a kanonikus útvonaltól $\beta$-katenin független és nem befolyásolja a Wnt célgének transzkripcióját. Wnt hiányában a Gsk3- $\beta$ (Drosophila Shaggy vagy Sgg) foszforilálja a mikrotubuluskötő Futsch fehérjét, ami olyan változást okoz a mikrotubulus szerveződésben, ami csökkenti a szinaptikus bouton képződést. Ezzel szemben Wnt jelenlétében a Fz2 receptor és az Lrp5/6 (Drosophila Arrow) ko-receptor komplex aktiválja a Dsh fehérjét, gátolva az Sgg függő Futsch foszforilációt [221], ami stabilizálja a 
mikrotublusokat, ezzel elősegítve az új boutonok létrejöttét [219, 220, 222]. Az utóbbi időben az is kiderült, hogy egy ismeretlen molekuláris mechanizmus által az Ank2 szintén a Wnt jelátvitel szabályozása alatt áll és valószínüleg ebben az útvonalban együttmüködik a Futschcsal [223]. Ha episztázis analízisben vizsgáljuk a futsch; Ank2 kettős homozigóta mutáns állatokat, akkor az tapasztalható, hogy a Futsch hiánya képes szuppresszálni az Ank2 mikrotubulus aggregációs fenotípusát. Valószínüleg a Futsch mikrotubulus stabilizáló funkciója szükséges ahhoz, hogy mikrotubulus aggregátumok létrejöjjenek az Ank2 mutáns állatokban. A hierarchia viszony nem egyértelmü a két fehérje között, mert a futsch; Ank2 kettős homozigóta mutánsok NMJ fenotípusa eltér a futsch egyes mutánsokétól [218].

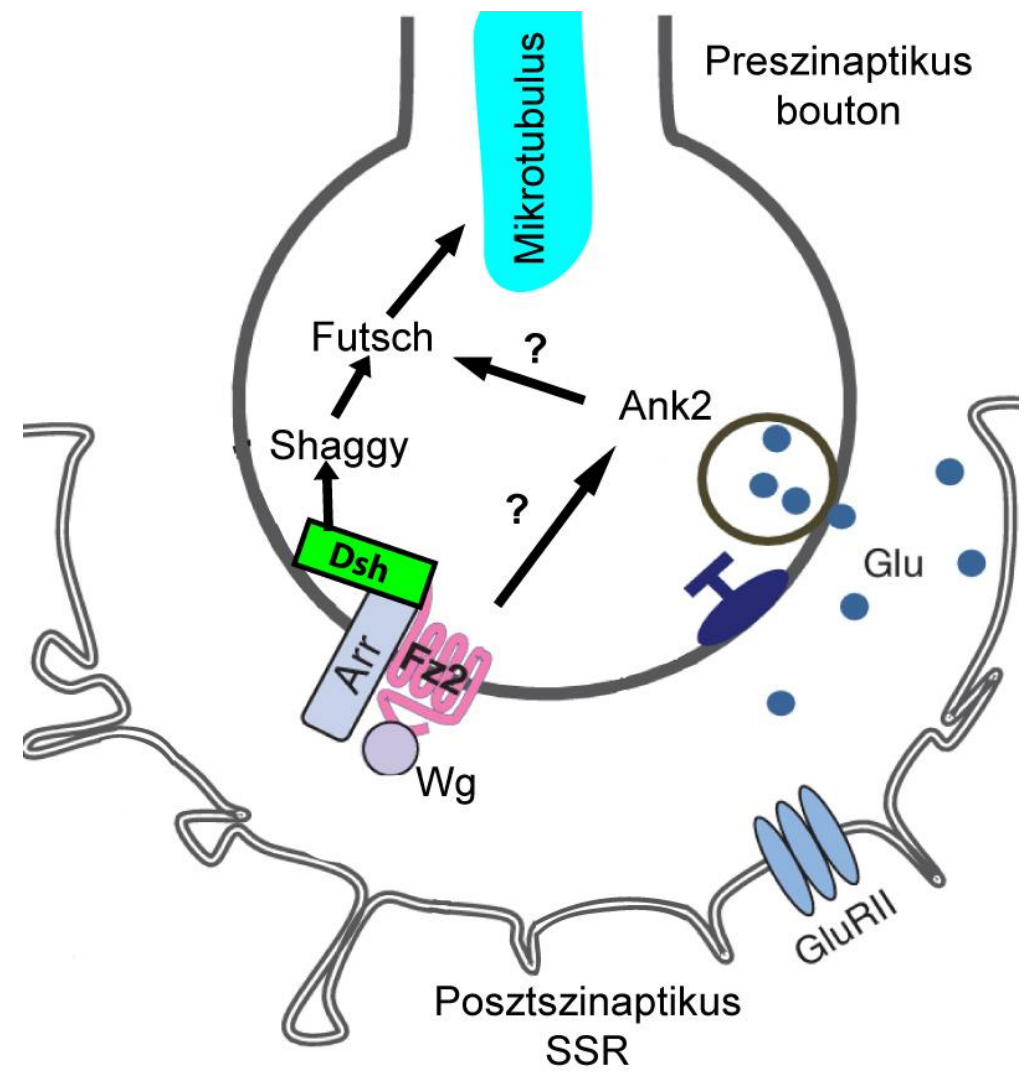

20. ábra A divergens Wnt kanonikus jelátviteli útvonal feltételezett múködése Drosophila NMJ-ben. A preszinaptikus oldalon lévő Wnt szignalizáció befolyásolja a mikrotubulus szerveződést elősegítve ezzel az új boutonok létrejöttét. Az ábra a [219]-es publikáció alapján módosítva.

A posztszinaptikus mikrotubulus organizációról eddigi ismereteink alapján nem sokat tudunk. Az emlős dendrittüskében korábban nem sikerült detektálni sem a mikrotubulusokat sem a mikrotubuluskötő fehérjéket [224]. Néhány közleményben volt utalás arra, hogy a mikrotubulusok megtalálhatóak a tüskékben, de egyértelmű bizonyíték nem volt rá. Néhány 
éve azonban több független irodalmi adat is megjelent arról, hogy a mikrotubulus $(+)$ vége képes belépni a dendrittüskékbe [225-227]. Ezenkívül azt is találták, hogy a mikrotubulus $(+)$ vége képes szabályozni az F-aktin szintet, ami létfontosságú a dendrittüske morfológiájának a megörzésében [227]. Ezeket az eredményeket megerősíti az, hogy a mikrotubulus (+) végkötő EB3 fehérje csendesítése nagymértékben csökkentette hippokampális idegsejtkultúrákban a dendrittüskék számát [225, 227]. Mindent egybe véve úgy tünik, hogy a szinaptikus sejtváz és funkció a dendrittüskékben érzékeny a mikrotubulus dinamika változásaira. Drosophila ismereteink nagyon szegényesek a posztszinaptikus mikrotubulusok vonatkozásában, valószínüleg a Spektrin/aktin hálózat és a mikrotubulusok között van valamilyen kapcsolat, de ennek funkciójáról, illetve jelentőségéről szinte semmit sem tudunk [176] . 


\section{CÉLKITÜZÉSEK}

A dDAAM formin típusú sejtvázszabályozó fehérje idegrendszeri funkcióját néhány évvel ezelött kezdtük el vizsgálni. A kísérleteink során megállapítottuk, hogy a dDAAM nagy mennyiségben kifejeződik az adult idegrendszerben, legföképpen az agy nyúlványban és szinapszisban gazdag neuropil régiójában. Továbbá az is kiderült, hogy a dDAAM az aktin összeszerelő aktivitása révén szerepet játszik az axon növekedés és navigáció folyamataiban. Később számos bizonyítékot adtunk arra vonatkozólag, hogy a dDAAM képes közvetlenül kötődni a mikrotubulusokhoz, valamint szerepe lehet az aktin/mikrotubulus kölcsönhatások elősegítésében. Folytatva tovább ezt a munkát, a következő célokat tüztük ki a kísérleteink során:

1. Tömegspektrometriai módszerekkel azonosítani a dDAAM lehetséges idegrendszer-specifikus kötőpartnereit.

2. Megvizsgálni, hogy a dDAAM a sejtvázszabályozás egyik fontos szereplőjeként részt vesz-e a szinaptikus fejlődésben.

3. Felderíteni a dDAAM szerepét a szinaptikus fejlődés során végbemenő sejtvázátrendeződési folyamatokban.

4. Genetikai interakciós vizsgálatok segítségével kideríteni, hogy milyen jelátviteli útvonalakkal állhat kapcsolatban a dDAAM az NMJ kialakulása során.

5. Megvizsgálni, hogy a dDAAM szerepet játszik-e a szinaptikus aktív zónák létrejöttében.

6. Elektrofiziológiai módszerekkel megvizsgálni, hogy a dDAAM hiánya befolyásolja-e szinaptikus transzmisszió hatékonyságát. 


\section{EREDMÉNYEK}

\section{A dDAAM kölcsönható partnereinek azonosítása központi idegrendszerből}

A dDAAM formin fehérje idegrendszeri funkciójának jobb megértéséhez biokémiai eszközökkel próbáltuk kideríteni, hogy a dDAAM milyen fehérjekomplexek tagja lehet. Ehhez egy nagy léptékü affinitástisztítást végeztünk, amelynek eredményét tömegspektrometriai módszerekkel analizáltuk. Az affinitástisztításnak számos módja létezik attól függően, hogy milyen oszlopot használunk a fehérjék kikötéséhez. A mi választásunk az anti-Flag oszlopra esett, mert mások tapasztalatai alapján kellően specifikus, illetve egyszerü és könnyű vele dolgozni. Az anti-Flag tisztításhoz szükségünk volt olyan dDAAM fúziós fehérjére, amely Flag taggel van ellátva. A tag egy olyan fehérjerészlet, amely lehetővé teszi, hogy a cél fehérjénk felismerhetővé váljon, így egy komplex szöveti mintából a feltárás után specifikusan ki tudjuk húzni a fehérjénket és szerencsés esetben a kölcsönható partnereit is.

A tag sok esetben befolyásolhatja a fehérje konformációját és működését attól függően, hogy a fehérjerészlet a célfehérje $\mathrm{N}$ - vagy C-terminálisán helyezkedik el, így úgy döntöttünk, hogy létrehozunk N-terminálisan (3xFlag::FLDAAM) és C-terminálsan tagelt (FLDAAM::3xFlag) teljes hosszúságú (FL) DAAM fúziós fehérjéket. A tageléshez 3xFlag taget használtunk, hogy megnöveljük a tisztítás specificitását és hatékonyságát. A fúziós fehérjék funkcionális vizsgálatához menekítési kísérleteket végeztünk, ahol az UAS/Gal4 rendszert használtuk, amely lehetővé teszi, hogy egy adott szövetben vagy minden szövetben kifejezzük a fúziós fehérjéket.

A menekítési kísérletekben arra voltunk kíváncsiak, hogy a $d D A A M$ null mutáns allél letális fenotípusát képesek-e menekíteni a dDAAM fúziós fehérjéket kifejező UAS-3xFlagFLDAAM és UAS-FLDAAM-3xFlag transzgének általános (da-Gal4) drivert használva. Azt tapasztaltuk, hogy az UAS-3xFlag-FLDAAM/+; da-Gal4/+ kombináció nem menekítette a dDAAM ${ }^{E x 68}$ letális fenotípusát, azonban az UAS-FLDAAM-3xFlag; da-Gal4/+ kombináció képes volt erre. A menekítési kísérletek azt mutatták, hogy a dDAAM N-terminális végén található Flag tag befolyásolja a fehérje funkcióját, viszont a C-terminális végén nem, ezért a FLDAAM::3xFlag fúziós fehérje alkalmas lehet az anti-Flag affinitástisztítás elvégzéséhez. Olyan mutáns törzseket hoztunk létre, amelyek kifejezik az FLDAAM::3xFlag fehérjét. A fúziós fehérje túltermelése esetén a következő lehetséges problémák merülhetnek fel: Elöször, ha vad típusú háttéren termeljük túl a FLDAAM::3xFlag fehérjénket, akkor az endogén 
dDAAM fehérje képes kompetálni a kötőpartnerért a fúziós fehérjével. Másodszor, a túltermeléssel olyan nagymértékben lesz jelen a FLDAAM::3xFlag fehérje, hogy képes lehet más fehérjékkel aspecifikusan kapcsolatot kialakítani.

A fentebb említett problémák elkerülése végett az affinitástisztításhoz két különbözö törzset hoztunk létre. Az első törzs esetében egy olyan hipomorf $d D A A M$ mutáns háttéren termeltük túl a fehérjét (dDAAM ${ }^{E x l} ; U A S-F L D A A M-3 x F l a g /+;$ act-Gal4/+), amelyben az endogén dDAAM fehérje szintje jelentős mértékben alacsonyabb a vad típushoz képest, így elkerüljük azt, hogy az endogén fehérje elvegye a lehetséges kötőpartnereket. A második törzsnél egy bonyolultabb megközelítést alkalmaztunk. A $d D A A M$ genomikus környezetében génkonverziós technika alkalmazásával egy C-terminálisan 3xFlag tagelt „knock-in” allélt $\left(d D A A M^{3 x F l a g}\right)$ hoztunk létre, ami azt eredményezte, hogy a dDAAM az összes a Flybase adatbázis által prediktált izoformája 3xFlag taget hordoz a fehérje C-terminális végén (21. ábra).

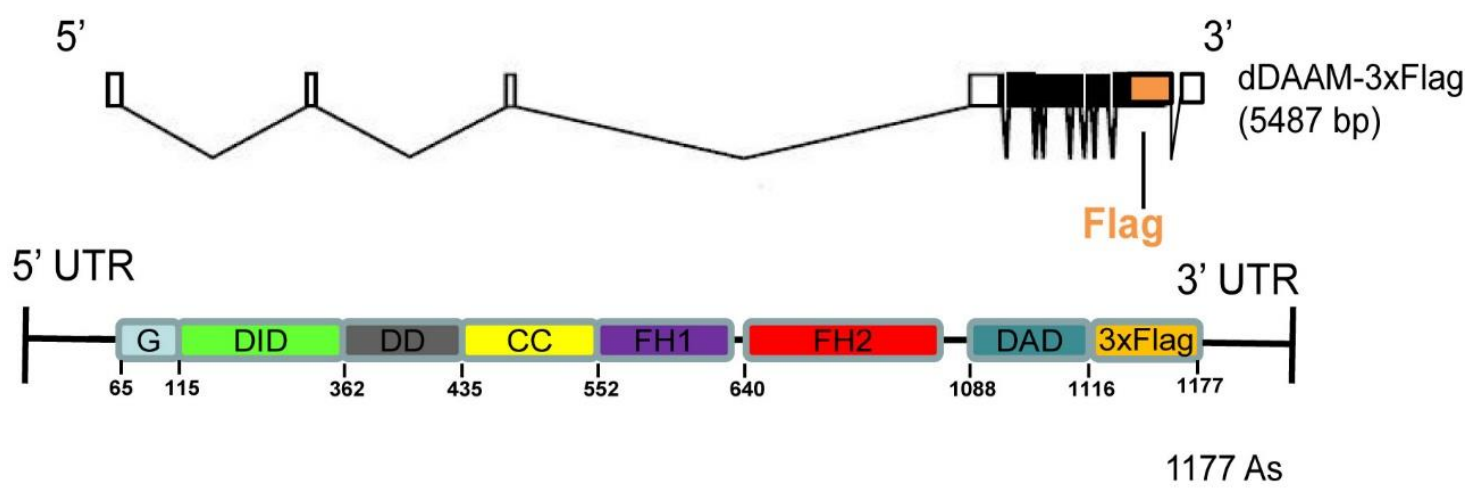

21. ábra A $\boldsymbol{A D A A} \boldsymbol{M}^{\text {Flag }}$ knock-in allél felépítése a $\boldsymbol{D D A A M}$ genomikus környezetében. A $d D A A M$ gén 3' végére a STOP kodon helyére beépítettünk 75 extra nukleotidot, amely a 3xFlag tag szekvencia részletet és a STOP kodont foglalja magába.

A létrehozott $d D A A M^{3 x F l a g}$ allél homo- és hemizigóta formában életképes, valamint a fúziós fehérje szintje közel azonos a vad típuséval, ami megerősíti a korábbi eredményeinket, vagyis hogy a dDAAM::3xFlag fehérje funkcionálisan aktív és ezáltal alkalmas lehet a fehérje tisztítás elvégzésére (22. ábra). 

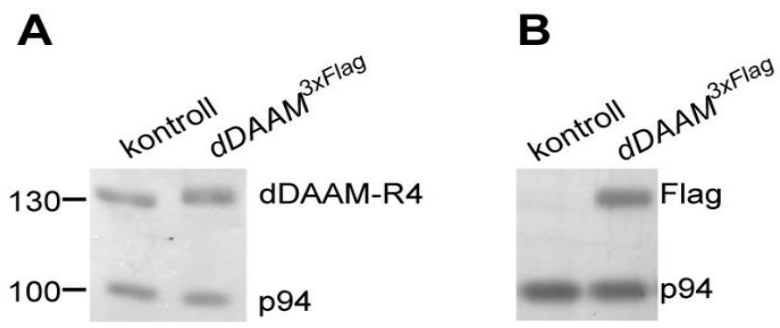

22. ábra A dDAAM fehérje kifejeződési szintje a $d D A A M^{\text {Flag }}$ mutáns állatokban (A-B) A dDAAM fehérje mennyiségének vizsgálata Western blottal. Az anti-p94 ellenanyagot belső kontrollként használtuk. (A) Az anti-dDAAM-R4 Western blot alapján a dDAAM::Flag kifejeződése közel azonos a vad típushoz képest. (B) Az anti-Flag Western blot egyértelmüen jelzi, hogy a dDAAM::Flag fehérje csak a $d D A A M^{3 x F l a g}$ állatokban fejeződik ki, a kontrollban $\left(w^{1118}\right)$ nem.

Az affinitástisztítás elvégzése során adult fejeket tártunk fel 3 különböző mintából kiindulva, ami a két dDAAM fúziós fehérjét kifejező vonalat (dDAAM ${ }^{E x I} ; U A S-F L D A A M 3 x F l a g /+;$ actGal4/+ és $\left.d D A A M^{3 x F l a g}\right)$ és a vad típusú kontrollként használt $\left(w^{1118}\right)$ törzset jelenti. A vad típusú kontroll minta az oszlophoz és az anti-Flag ellenanyaghoz aspecifikusan kikötődött fehérjék kizárására szolgált.

\begin{tabular}{|llcc|}
\hline Uniprot ID & Fehérje & egyedi peptid & $\Sigma$ peptid \\
M9MSM5 & DAAM $^{* *}$ & 147 & 2771 \\
Q9W596 & Futsch* $^{*}$ & 24 & 37 \\
Q9NFU0 & FMR1* $^{*}$ & 5 & 10 \\
Q7KU92 & Ankyrin2 $^{* *}$ & 5 & 9 \\
P18431 & Shaggy* $^{*}$ & 3 & 4 \\
\hline
\end{tabular}

23. ábra A dDAAM lehetséges kötőpartnereinek MS analízissel történő azonosítása A tisztítást követően a dDAAM::Flag fúziós fehérjét tartalmazó fehérjekomplexeket MS analízissel vizsgáltuk. Lehetséges dDAAM kötőpartnerként számos szinaptikus és mikrotubuluskötő fehérjét azonosítottunk. * azokat a fehérjéket jelöli, amelyek csak az anti-Flag mintában azonosíthatóak a kontrollban $\left(w^{1118}\right)$ nem. ** jelöli azokat a fehérjéket, amelyeknek a relatív mennyisége legalább kétszerese a kontrollhoz képest. A fehérjék relatív mennyisége az egyes mintákban megbecsülhető az ún. spektrumszámlálás módszerével. Ehhez először meghatározzuk, hogy az adott mintasorozaton belül egy adott fehérjére összesen hány azonosított peptid esik, illetve ezt a számot elosztjuk az összes azonosított peptidszámmal. A kapott hányados mintasorozatok közötti összehasonlításával megbecsülhető az adott fehérje mennyiségi változása, ha a normalizált peptidszámok hányadosa a medián érték $0.5 *$-énél kisebb vagy $2 *$-énél nagyobb, akkor tekintjük mérvadónak a változást. Azokat a fehérjéket tekintettük pozitív találatnak, amelyeket legalább 3 egyedi peptiddel azonosítottunk a dDAAM::Flag-et tartalmazó mintában. 
A 3 különböző mintából származó fehérjéket eluáltuk az anti-Flag oszlopról, majd ezt követően tömegspektrometriai (LC/MS-MS) vizsgálatnak vetettük alá. Az LC/MS-MS vizsgálatok után azokat a fehérjéket tekintettük lehetséges dDAAM kötőpartnernek, amelyek a kontroll mintában, nem vagy csak kis mennyiségben azonosíthatóak szemben a fúziós fehérje mintákkal, ahol ezeknek a fehérjéknek a mennyisége jelentősen megnő. Meglepetésünkre a dDAAM lehetséges kötőpartnerei között számos szinaptikus (Futsch, Ank2, Sgg, FMR1) és/vagy miktrotubulus szabályozásban résztvevő (Futsch, Shaggy) fehérjét azonosítottunk (23. ábra). A biokémiai kísérletek után úgy döntöttünk érdekes lenne megvizsgálni, hogy a dDAAM a sejtvázszabályozás egy fontos szereplőjeként részt vesz-e a szinaptikus fejlődésben vagy a szinaptikus müködésben.

\section{A dDAAM fehérje szerepének vizsgálata az embrionális szinapszisképződésben}

A szinapszisképződés folyamatainak vizsgálatához elsősorban a lárvális NMJ-t választottuk mint szinaptikus modellrendszert, de érdekesnek tartottuk megvizsgálni azt is, hogy részt vesz-e a dDAAM a szinapszisképződés korai folyamataiban. Ehhez 15-17 stádiumos embriókat választottunk, amelyekben a motoraxonok felismerik a célsejtjüket és elkezdődik a szinapszisok érése. Először megvizsgáltuk azt, hogy a dDAAM fehérje kifejeződik-e az embrionális motoraxonok terminálisainál. A vizsgálatainkhoz az anti-FasciclinII (FasII) ellenanyagot választottuk embrionális motoraxon markerként (24. ábra B), amely nagymértékü kolokalizációt mutatott a dDAAM fehérje mintázattal mind az embrionális KIR területén, mind az idegek perifériás végződésénél, ahol az NMJ található (24. ábra C). Ezenkívül a mikroszkópos felvételeken az is egyértelműen látszik, hogy a dDAAM a preszinaptikus idegvégződés mellett a posztszinaptikus izomsejtben is jelen van (24. ábra A), ami jelzi azt, hogy a dDAAM pre- és posztszinaptikus kifejeződést egyaránt mutat. A lokalizációs eredményeket megerösítve funkcionális vizsgálatokat is végeztünk, ahol a $d D A A M$ null mutáns alléljának $\left(d D A A M^{E x 68}\right)$ hatását vizsgáltuk szintén 15-17 stádiumú embrionális NMJ-ken. A funkcióvesztéses analízishez a 6/7 és a 12/13 izmokhoz tartozó ISNb axon végződést vizsgáltuk. A vizsgálatok alapján a $d D A A M^{E x 68}$ mutáns embriók 63\%-a mutatott motoraxon navigálási vagy növekedési hibát az NMJ terminálisoknál, ami egyértelmüen jelzi, hogy a dDAAM szükséges már a szinapszisképződés korai folyamataiban is (25. ábra). 

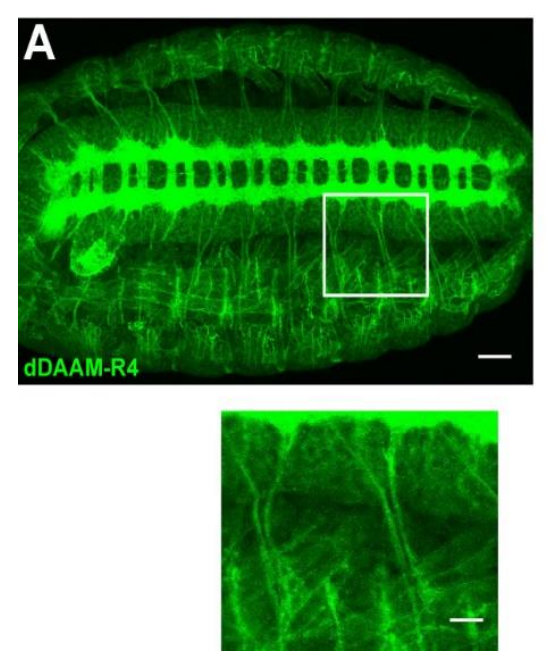
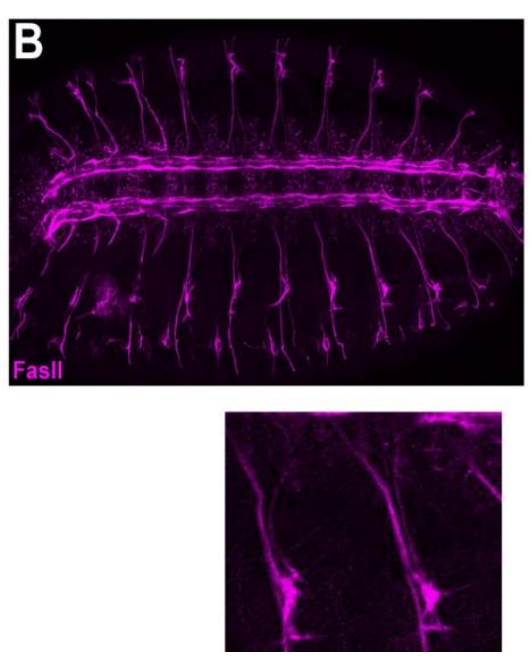
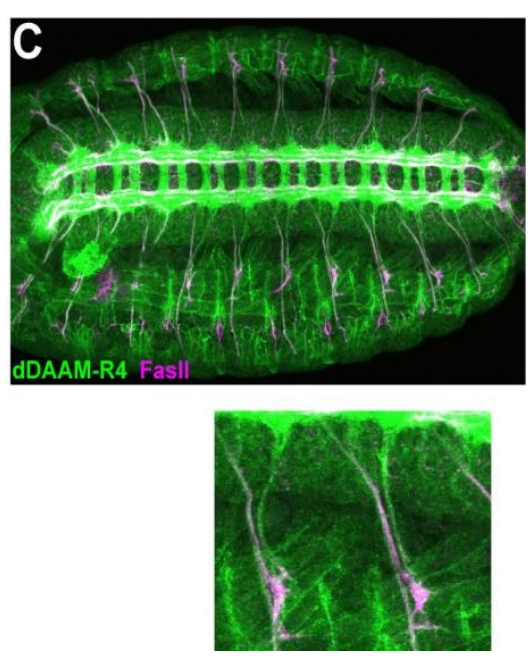

\section{4. ábra A dDAAM expressziós mintázata az embrionális központi idegrendszer területén. (A-C)}

A dDAAM kifejeződésének vizsgálata 15. stádiumú kontroll $\left(w^{1118}\right)$ embriókon anti-dDAAM-R4 immunfestéssel (A, C). A dDAAM nagymértékü kolokalizációt mutat a Fas II motorneuron specifikus fehérjével $(\mathrm{B}, \mathrm{C})$ beleértve az axon terminális régióját is (kinagyítva a fö panelek alatt). A skála mérete: $20 \mu \mathrm{m}$ (A-C), $10 \mu \mathrm{m}$ (A-C a kinagyított képeken).

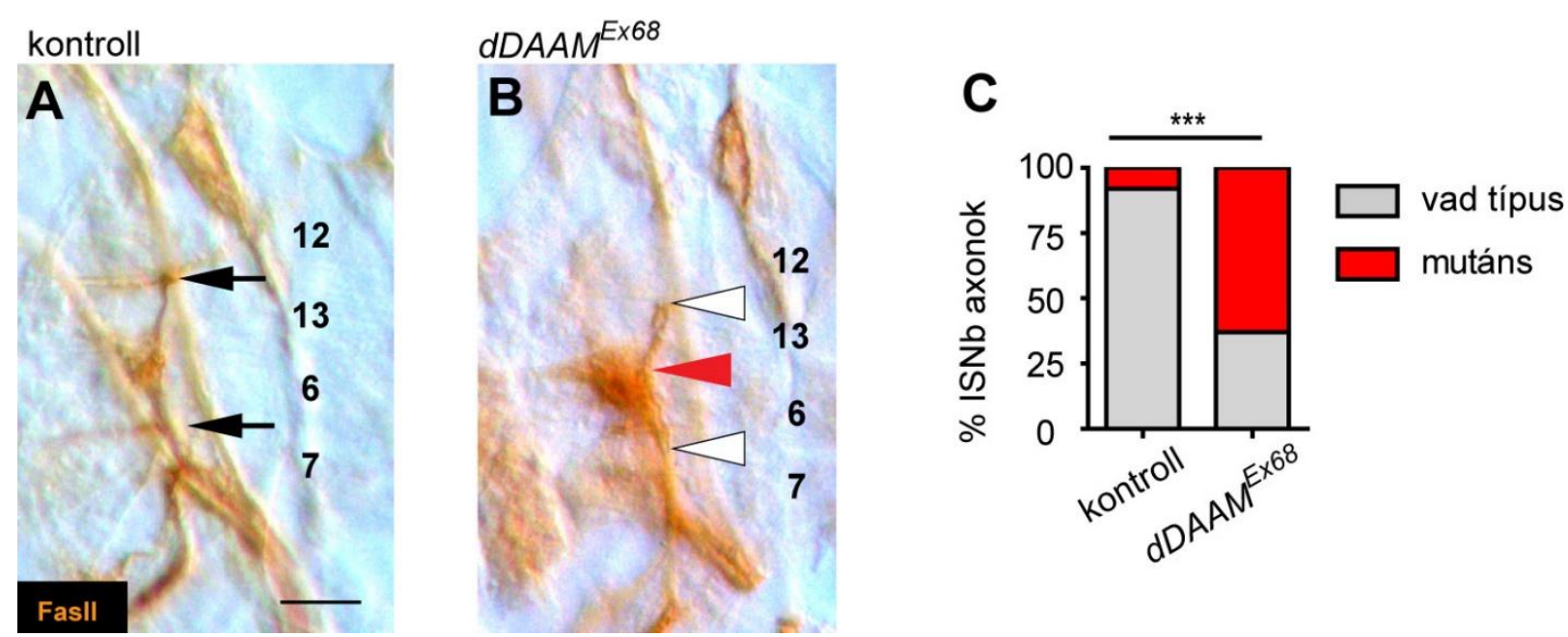

25. ábra A dDAAM fehérje szükséges az embrionális NMJ képződéshez. (A) A vad típusú embriók több mint 90\%-ban (C) a Fas II poztív ISNb motoraxonok a 6/7 és 12/13 izmoknál szinaptikus végződéseket hoznak létre (fekete nyilak). (B) Az ISNb axon terminálisok dDAAM hiányában korai terminációkat vagyis axon navigálási hibákat (fehér nyilak) mutatnak a mutáns embriók 63\%-ban (C). Továbbá a $d D A A M^{E x 68}$ mutáns ISNb motoraxonok esetében növekedési hibák is gyakran előfordulnak, amit jelez az erős FasII felhalmozódás (piros nyíl). A skála mérete: $20 \mu \mathrm{m}$ (A-B). *** p $<0.001 . \mathrm{n} \geq 100$ (C). 


\section{A dDAAM fehérje szükéges a lárvális NMJ képződéshez}

Ahogy az a bevezetőben is említésre került, a lárvális növekedés legnagyobb kihívása, hogy az NMJ-k képesek legyenek követni az izomméret nagymértékü növekedését a szinaptikus transzmisszió hatékonyságának csökkenése nélkül. Ehhez a bouton és az aktív zóna képződés folyamatainak szigorú koordinálására van szükség. Ahhoz, hogy megvizsgáljuk azt, hogy a dDAAM érintett-e ezekben a folyamatokban, megnéztük a dDAAM fehérje kifejeződését az NMJ terminálisoknál. A szinaptikus végek megjelenítéséhez az anti-HRP preszinaptikus membrán markert és az anti-Dlg posztszinaptikus markert használtuk. A mikroszkópos vizsgálatok alapján, hasonlóan az embrionális kifejeződési mintához, a dDAAM a pre- és a posztszinaptikus oldalon egyaránt kifejeződik (26. ábra A), ahol túlnyomó részt kortikális feldúsulást mutat. A lárvális NMJ-ben megfigyelhető dDAAM kortikális felhalmozódása a $D D A A M$ null mutáns állatokban szinte teljesen eltünik (26. ábra B), ami arra utal, hogy az anti-dDAAM-R4 ellenanyag specifikus az NMJ terminálisban.
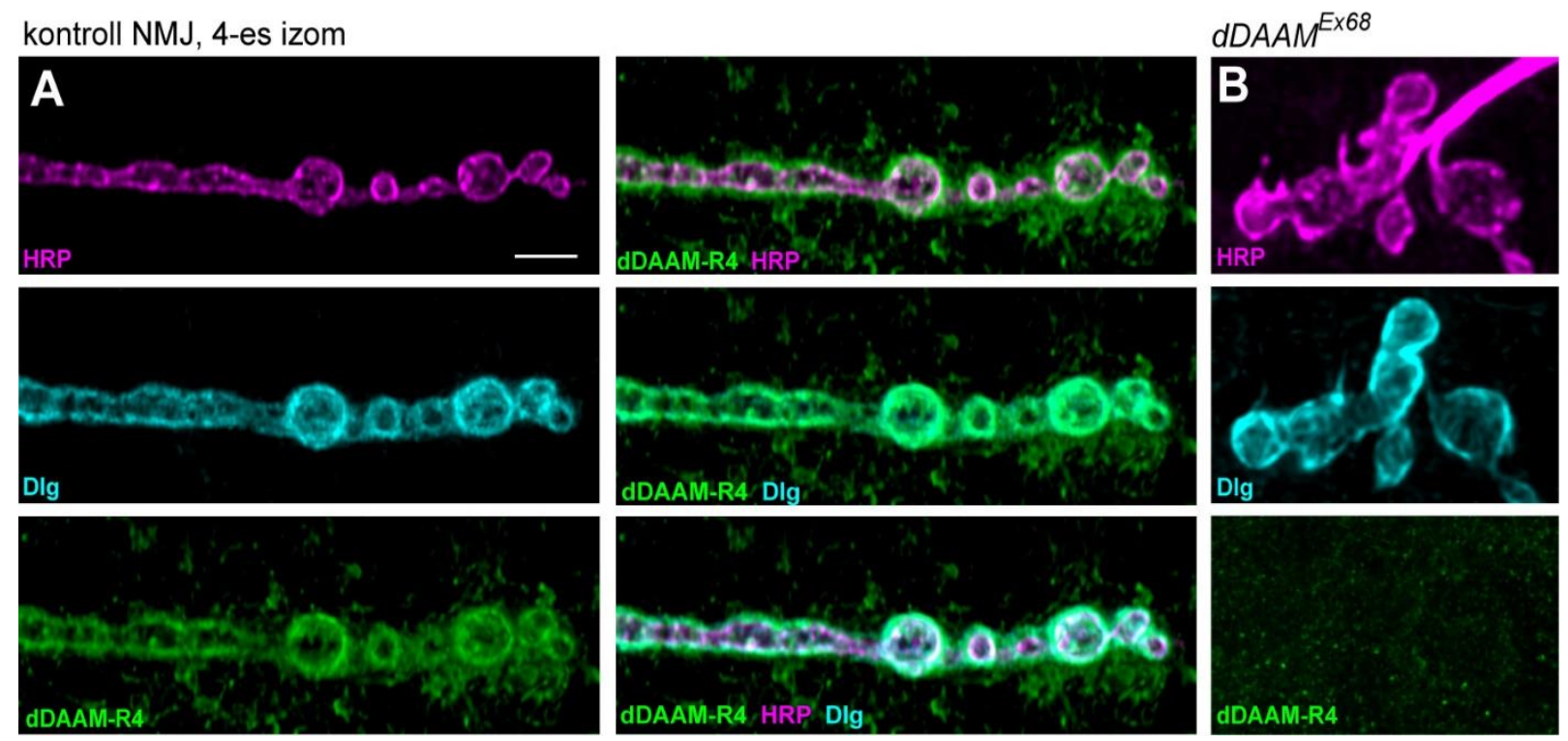

26. ábra A dDAAM nagymértékben kifejeződik a lárvális NMJ pre- és posztszinaptikus oldalán.

(A-B) A konfokális képeken anti-HRP (magenta), anti-Dlg (cián) és anti-dDAAM-R4 (zöld) immunfestésekkel vizsgáltuk a lárvális 4-es izom NMJ végződését. (A) A vad típusú állatokban a dDAAM erős kortikális felhalmozódást mutat a pre- és posztszinaptikus oldalon egyaránt. (B) A $d D A A M^{E x 68}$ mutáns NMJ-ben az anti-dDAAM-R4 immunfestés szinte teljesen eltűnik, ami az ellenanyag specifikusságára utal. A skála mértéke: $5 \mu \mathrm{m}$. 
A lokalizációs után funkcionális vizsgálatokat terveztünk. Összhangban az embrionális NMJ analízissel funkcióvesztéses vizsgálatokat végeztünk a $d D A A M^{E x 68}$ amorfnak tekintett alléljával. Fontos megemlíteni, hogy a $d D A A M$ gén citológiailag az X kromoszómára térképeződik, ezért hemizigóta $d D A A M^{E x 68}$ null mutáns állatokkal dolgoztunk, amelyek nagyobb része korai stádiumú lárvaként elpusztul, viszont néhány egyed eléri a 3. lárvális stádiumot csökkent test- és izomméret kíséretében. Figyelembe véve, hogy az izomméret az NMJ fejlődés egyik kulcs tényezője, hasonló méretü 2. stádiumú vad típusú, illetve $d D A A M$ mutáns lárvákat vizsgáltunk, amelyekben az ugyanolyan típusú izmok felszíne nagymértékben megegyezett egymással (27. ábra I, J). Anti-HRP és anti-Dlg szinaptikus markereket használva azt tapasztaltuk, hogy a 4-es izomhoz tartozó NMJ szinaptikus boutonainak száma 35\%-kal alacsonyabb a $d D A A M$ null mutánsban a vad típushoz képest (27. ábra A, B, G). Hasonló bouton szám csökkenést tapasztaltunk a $d D A A M$ mutáns 6/7 izom NMJ terminálisainál (27. ábra D, E, H), ami arra utal, hogy a dDAAM-nak általános szerepe lehet az NMJ fejlődésben. A dDAAM mutánsban látható bouton szám csökkenést az NMJ terminális hosszának csökkenése is kíséri a 4-es és 6/7 izomnál egyaránt (27. ábra K,L), ami megerősíti azt a feltételezésünket, hogy a dDAAM-nak szerepe van az NMJ terminális kialakulásában. A további kísérleteinkben csak a 4-es izomhoz tartozó NMJ-t vizsgáltuk annak egyszerü Y alakú struktúrája és könnyü azonosíthatósága miatt. Habár a 2. stádiumos lárvák vizsgálatából származó eredmények egyértelműnek tűntek, a funkcióvesztéses kísérleteinket ki akartuk terjeszteni vándorló 3. stádiumos állatokra is, ugyanis a dinamikusan növekvő 2. stádiumos lárvához képest a jóval nagyobb méretü 3. stádiumos NMJ egy finomabb és részletesebb vizsgálatot tesz lehetővé. Korábbi eredményeink alapján tudjuk, hogy a dDAAM fontos szerepet játszik a trachea kutikula mintázat kialakításában [228], ezért úgy gondoltuk, hogy a $d D A A M^{E x 68}$ null mutáns állatokban megfigyelhető trachea fenotípus egy olyan hipoxiás állapotot idéz elő, ami felelős lehet az állatok csökkent testméretért és letalitásáért. 

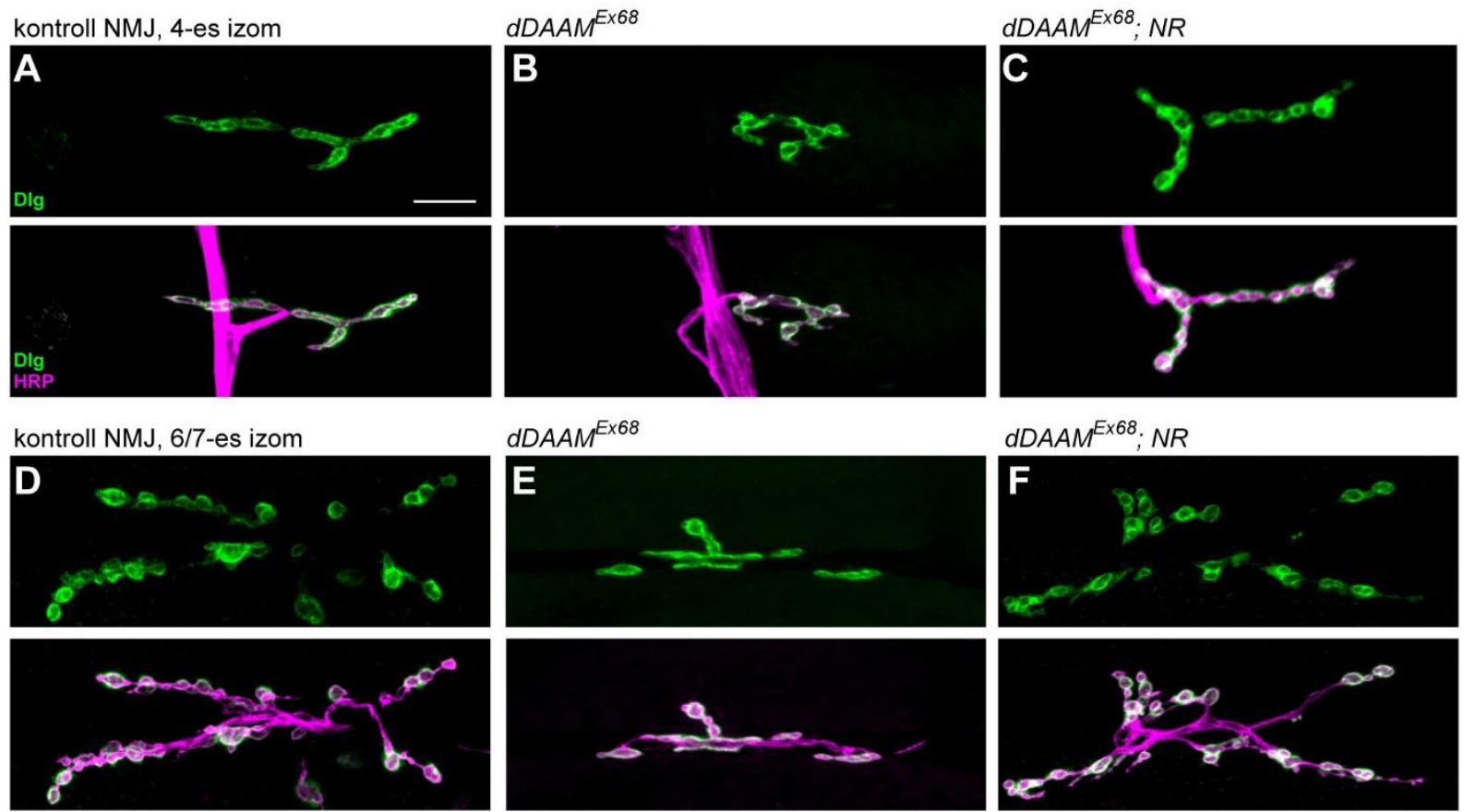

dDAAM ${ }^{E \times 68}$

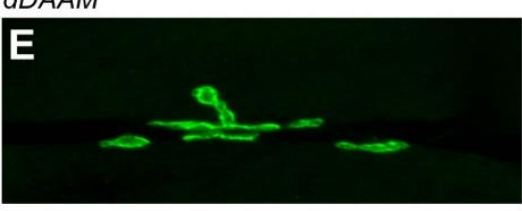

$d D A A M^{E \times 68} ; N R$
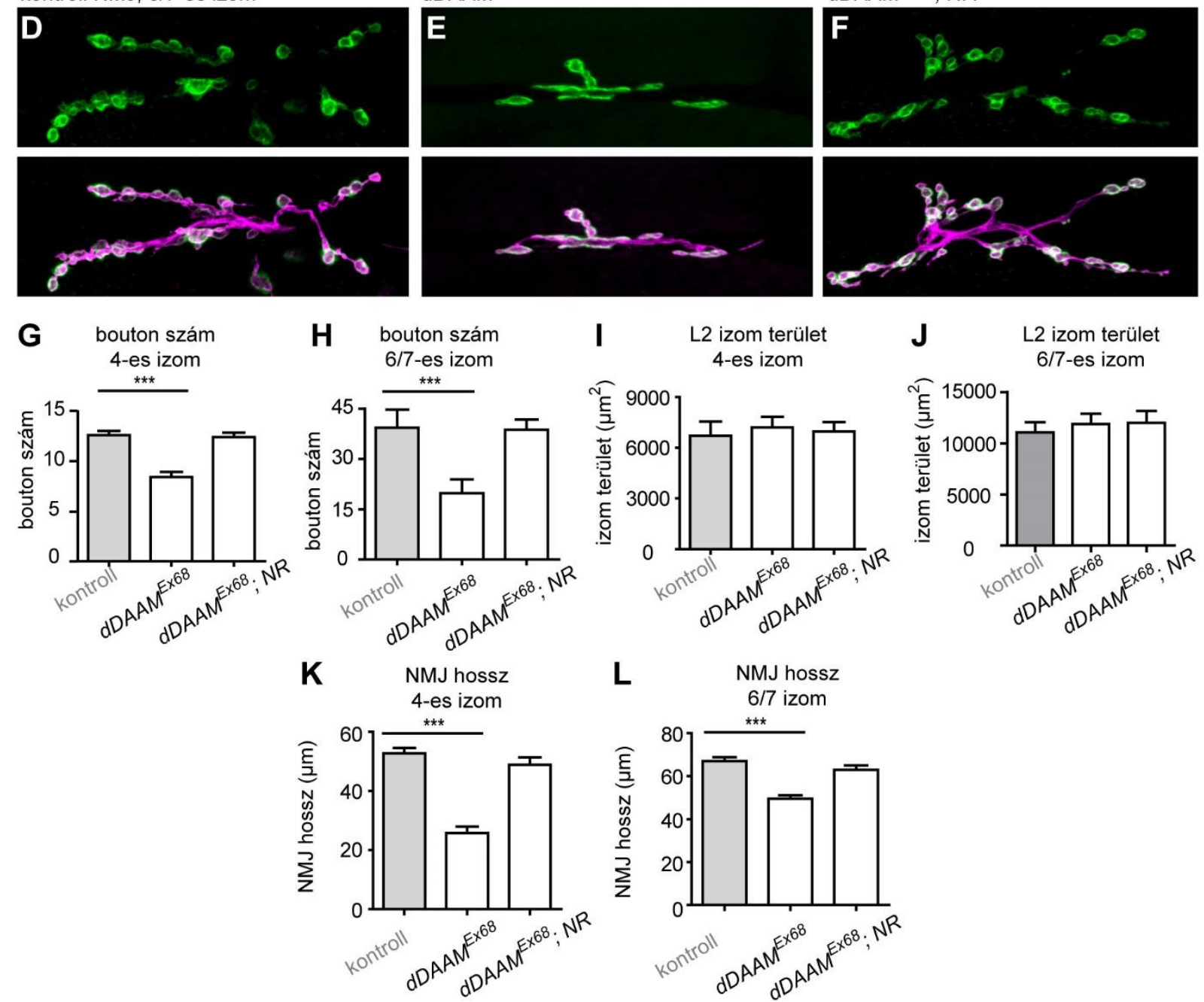

27. ábra A dDAAM hiánya bouton szám csökkenést és rövidebb NMJ végződést eredményez. (A-F) Anti-HRP és anti-Dlg NMJ immunfestések második fejlődési stádiumú lárvák 4-es (A-C) és 6/7es (D-F) izmainál vizsgálva a kontroll $\left(w^{1118}\right)(\mathrm{A}, \mathrm{D}), d D A A M^{E x 68}(\mathrm{~B}, \mathrm{E})$ és $d D A A M^{E x 68} ; N R$ $\left(d D A A M^{E x 68} / Y\right.$; UAS-FLDAAM/+; D42-Gal4/+) (C, F) genotípusokat. Az NMJ terminálisok morfológiáját a 4-es és 6/7-es izmoknál a bouton szám $(\mathrm{G}, \mathrm{H})$ az izomfelszín (I, J) és az NMJ hossz (K, L) függvényében jellemeztük a fent említett genotípusokban $\mathrm{n} \geq 25$. A skála mértéke: $5 \mu \mathrm{m}$ (A-F). Az oszlopok átlagértékeket ábrázolnak a szórások feltüntetésével (G-L). *** $\mathrm{p}<0.001$ 
A trachea fenotípus menekítéséhez $d D A A M^{E x 68}$ null mutáns háttéren a dDAAM teljes hosszúságú formáját tracheaspecifikus szabályozás alatt álló driverrel (btl-Gal4) túltermeltük, létrehozva ezzel ( $d D A A M^{E x 68} / Y$; btl-Gal4, UAS-FLDAAM/+) mutáns kombinációt, amit a későbbiekben $d D A A M^{E x 68} ; T R$-ként fogok hivatkozni. Az elvártaknak megfelelően a $d D A A M^{E x 68} ; T R$ állatokban szakadásmentes, vad típusra emlékeztető trachearendszer alakult ki, amely menekítette az $d D A A M^{E x 68}$ null mutáns állatok csökkent test- és izomméretét, valamint letális fenotípusát. Tehát a tracheaspecifikus menekítéssel sikerült olyan $d D A A M$ mutáns 3. stádiumos vándorló lárvákat létrehozni, amelyekben az izomfelszínnek a mérete megegyezik az ugyanolyan korú vad típusúéval, viszont a pre- és posztszinaptikus oldalon egyaránt dDAAM hiányos állapot van.

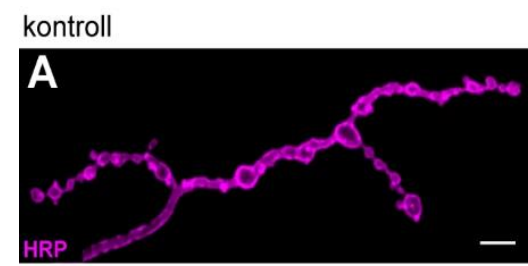

dDAAM ${ }^{E \times 68} ; T R$

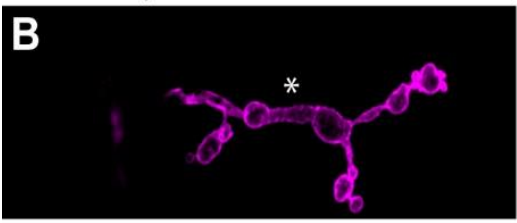

pre-és posztszinaptikus $d D A A M$ RNSi 1

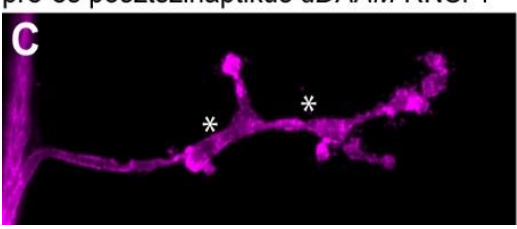

posztszinaptikus $d D A A M$ RNSi 1

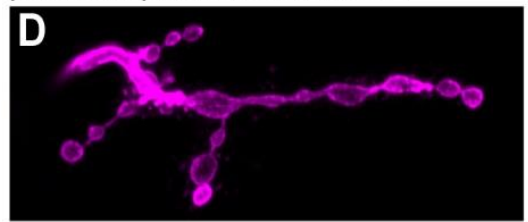

preszinaptikus $d D A A M$ RNSi 2

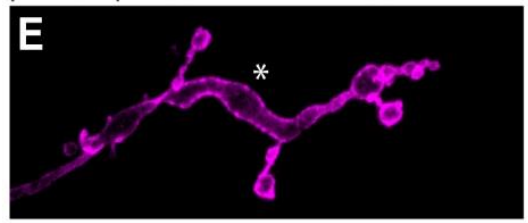

preszinaptikus $\mathrm{dDAAM}$ RNSi 2

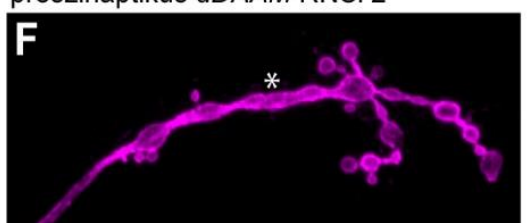

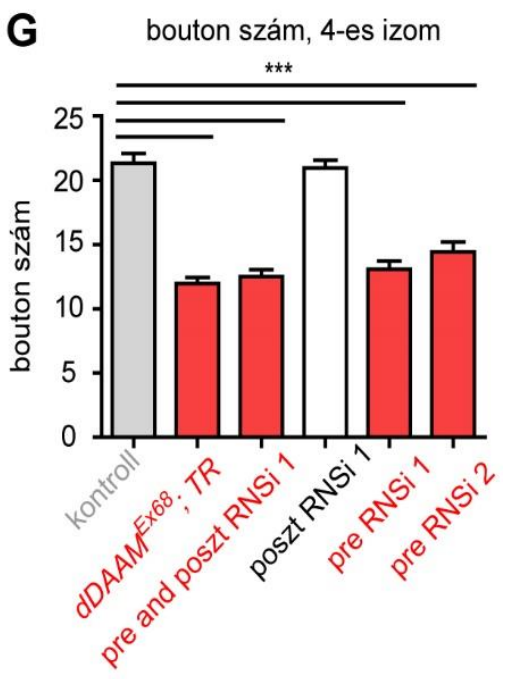

28. ábra A preszinaptikus dDAAM szükséges a lárvális bouton képződéshez. (A-F) A konfokális képeken anti-HRP immunfestéssel vizsgáltuk a lárvális 4-es izom NMJ végződését. A kontroll (elavGal4/+) (A) és a posztszinaptikus dDAAM RNSi 1 állatokban (mef2-Gal4/+; UAS-dDAAM-RNSi 1/+) (D) az NMJ terminálisok a vad típusra jellemző gyöngyfüzérszerü bouton szerveződést mutatnak, ettől eltéröen a $d D A A M^{E x 68} ; T R\left(d D A A M^{E x 68} / Y\right.$; btl-Gal4, UAS-FLDAAM/+) (B), a pre- és posztszinaptikusan dDAAM csendesített (elav-Gal4, mef2-Gal4/+; UAS-dDAAM-RNSi 1/+) (C), valamint a preszinaptikusan csendesített állatokban (elav-Gal4/+; UAS-dDAAM-RNSi 1/+ és elav-Gal4/+; UAS$d D A A M-R N S i$ 1/+) (E, F) bouton szám csökkenés és bouton fúziós fenotípus (csillag jelölés) figyelhetö meg. (G) A bouton szám változásának statisztikai elemzése a különböző $d D A A M$ mutánsokban. $\mathrm{n} \geq 25$. A skála mértéke: $5 \mu \mathrm{m}$ (A-F). Az oszlopok átlagértékeket ábrázolnak a szórások feltüntetésével (G). $* * * \mathrm{p}<0.001$ 
Összhangban a korábbi vizsgálatokkal, a 3. stádiumos vándorló $d D A A M^{E x 68}$; $T R$ állatokban a bouton szám 45\%-os csökkenését figyeltük meg a vad típushoz képest (28. ábra B, G). A mikroszkópos képek vizsgálata során azt is észrevettük, hogy a boutonokat összekötő interboutonikus régiók, amik a vad típusú NMJ-ben a boutonnál lényegesen keskenyebb struktúrák, kiszélesednek és azok átmérője gyakran megközelíti a bouton átmérőjét (későbbiekben bouton fúziós fenotípus). Ahhoz, hogy megerősítsük a legutóbbi megfigyeléseinket elhatároztuk, hogy RNS interferncia segítségével csendesítjük a $d D A A M$ gént az NMJ terminálisban. Először a pre- és posztszinaptikus oldalon egyaránt túltermeltük a dDAAM RNSi konstrukciókat idegrendszer specifikus elav-Gal4 és izomspecifikus mef2-Gal4 driverek segítségével. Két független RNS interferncia vonalat használtunk (UAS-dDAAM RNSi 1 és UAS-dDAAM RNSi 2), azért hogy elkerüljük az off-target hatás lehetőségét. A csendesítés után mindkét vonal esetében a $d D A A M^{E x 68} ; T R$ állatokra emlékeztető csökkent bouton számmal és fúziós boutonnal járó NMJ fenotípus volt megfigyelhető (28. ábra C, G, nincs mutatva). A kétoldali csendesítés után megvizsgáltuk, hogy külön-külön a pre- vagy posztszinaptikus csendesítésnek van-e valamilyen hatása a szinaptikus fejlődésre. A preszinaptikus dDAAM csendesítés bouton szám csökkenéshez vezetett (24. ábra E-G), viszont a posztszinaptikus RNSi nem okozott változást az NMJ morfológiában (24. ábra D, G). Így a csendesítési kísérletek a dDAAM preszinaptikus szerepére utalnak. A csendesítés specifikusságának és hatékonyságának a tesztelésére további kísérleteket végeztünk el. Először Western blottal néztük meg azt, hogy a két különböző dDAAM RNSi transzgénnel csendesített állatokban mennyire csökken le a dDAAM fehérje szintje. A denzitometriai elemzést követően a $U A S-d D A A M$ RNSi 1 vonal esetében a dDAAM fehérje szintje körülbelül 98\%-kal, míg a UAS-dDAAM RNSi 2 vonal esetében nagyjából 92\%kal csökken a vad típushoz képest, ha az elav-Gal4, mef2-Gal4 driver kombinációt használtuk (29. ábra A, B). Összhangban a Western blot kísérletekkel az anti-dDAAM immunfestés szinte teljesen eltűnt a dDAAM csendesített NMJ terminálisokban (29. ábra C, D). 


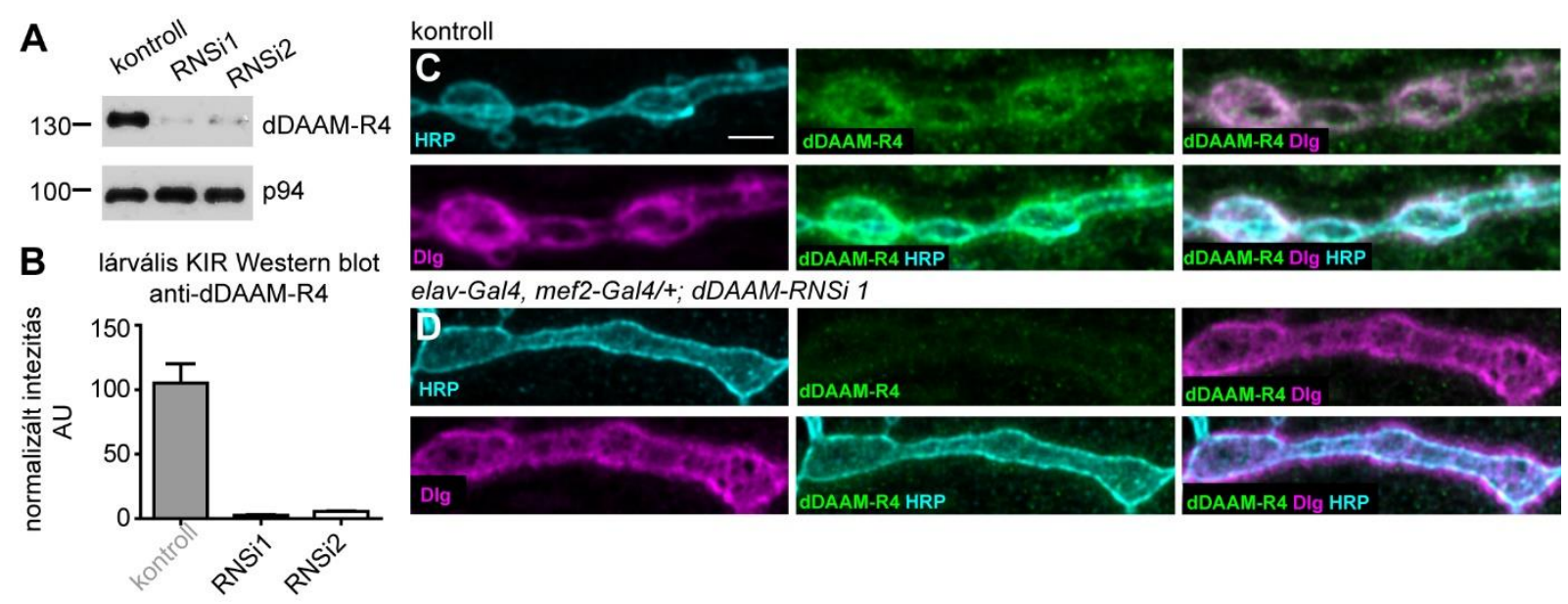

29. ábra A dDAAM csendesítés hatékonyságának a vizsgálata. (A, B) A Western blot kísérletek alapján a dDAAM specifikus RNSi vonalak elav-Gal4 driver használatával (elav-Gal4/+; UASdDAAM-RNSi 1/+ és elav-Gal4/+; UAS-dDAAM-RNSi 2/+) és nagy hatékonysággal csendesítik a dDAAM gént a KIR-ben. (C) A kontroll (elav-Gal4, mef2-Gal4/+) állatokban látható kortikális dDAAM felhalmozódás (zöld) szinte teljesen eltünik a pre- és posztszinaptikusan dDAAM csendesített állatokban (elav-Gal4, mef2-Gal4/+; UAS-dDAAM-RNSi 1/+) (D), ami nem befolyásolta az ant-HRP (cián) és anti-Dlg (magenta) szinaptikus markerek festődési mintázatát. Az oszlopok átlagértékeket ábrázolnak a szórások feltüntetésével (I). $\mathrm{n} \geq 10$. A skála mértéke: $3 \mu \mathrm{m}(\mathrm{C}, \mathrm{D})$.

Annak érdekében, hogy bebizonyítsuk, hogy az általunk megfigyelt NMJ fenotípusok valóban a preszinaptikus dDAAM hiányának köszönhetőek, menekítési kísérleteket végeztünk a mutáns analízishez használt $d D A A M^{E x 68}$ alléllel. A korábban használt $U A S-F L D A A M$ transzgént a preszinaptikus oldalon, motorneuron-specifikus driverrel (D42-Gal4) termeltettük túl dDAAM ${ }^{E x 68}$ mutáns háttéren, ezzel létrehozva a $\left(d D A A M^{E x 68} / Y\right.$; UAS-FLDAAM/+; D42Gal4/+) mutáns állatokat (későbbiekben $d D A A M^{E x 68} ; N R$ ). A preszinaptikusan menekített $d D A A M^{E x 68} ; N R$ egyedekben vad típushoz hasonló NMJ morfológia alakult ki a bouton szám és az NMJ hossz vonatkozásában egyaránt (27. ábra C, F, G, H, K, L). Összességében a $d D A A M$ funkcióvesztéses vizsgálata megmutatta, hogy a dDAAM befolyásolja az NMJ fejlődés folyamatait, elősegítve a szinaptikus boutonok kialakulását. Habár a fehérje mindkét szinaptikus félen kifejeződik, a funkcióvesztéses analízis a dDAAM preszinaptikus szerepére utal. 


\section{A dDAAM a preszinaptikus mikrotubulus stabilizálódás pozitív szabályozó faktora}

Mivel a dDAAM egy formin típusú sejtvázszabályozó fehérje, ezért úgy gondoltuk, hogy megvizsgáljuk a szerepét az NMJ citoszkeletális szerveződésében. A korábban ismertetett MS analízis legígéretesebb dDAAM kölcsönható partnereként a Futsch fehérje tűnt, ami egy széles körben használt preszinaptikus mikrotubulus marker. Ismert tény, hogy a Futsch kötődve a mikrotubulusokhoz képes elősegíteni azok stabilizálódását, ezáltal elősegítve az új boutonok képződését [122, 123]. A fentiek alapján felmerült, hogy a dDAAM befolyásolja-e a preszinaptikus mikrotubulus szerveződést.

A preszinaptikus mikrotubulusok vizsgálatához anti-Tubulin és anti-Futsch immunfestést használnak leginkább, amelyek közül az anti-Futsch immunfestés a szélesebb körben elterjedt, mivel a Futsch csak preszinaptikusan fejeződik ki. Az anti-Tubulin ellenanyagok kevésbé népszerű markerek, mert a pre- és posztszinaptikus oldalon lévő mikrotubulusokat egyaránt felismerik, megnehezítve ezzel a vizsgálatukat. A vad típusú preszinaptikus motoraxon végződésben az anti-Futsch immunfestést használva megfigyelhető, hogy a központi mikrotubulus sejtváz egy egységes kötegbe rendeződik [122], amely fokozatosan a preszinaptikus terminális disztális része felé haladva elvékonyodik (30. ábra AAb). A terminális boutonban a mikrotubulus leginkább szabálytalan módon szétterül vagy alacsony előfordulási gyakorisággal alig észlelhető (30. ábra $\mathrm{Ab})$. Ettől eltérően a $D D A A M^{E x 68}$; $T R$ állatokban a preszinaptikus központi mikrotubulus köteg az anti-Futsch immunfestés alapján fragmentált megjelenésü, illetve a mikrotubulusok a terminális boutonokból gyakran

hiányoznak (30. ábra $\mathrm{B}-\mathrm{Bb})$. Hasonlóan a $d D A A M^{E x 68} ; T R$ NMJ végződésekhez a preszinaptikusan dDAAM csendesített NMJ terminálisokban a Futsch lokalizációja szabálytalan granulált mintázatot vesz fel valamint a terminális boutonokban gyakran nem detektálható (30. ábra C-Cb). 

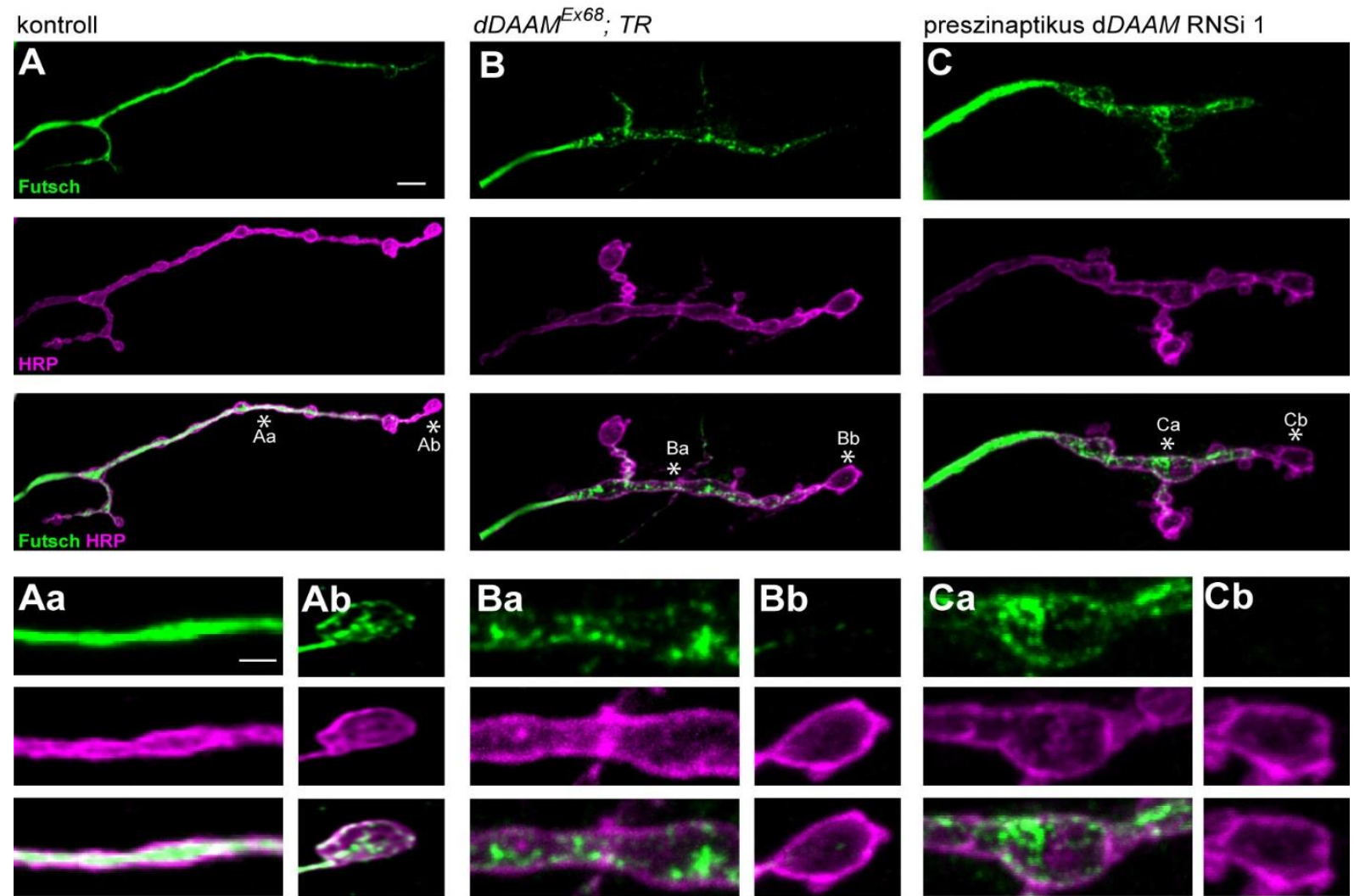

Daximum inter-bouton
átmérö

E

Mikrotubulus szerveződés a terminális boutonokban
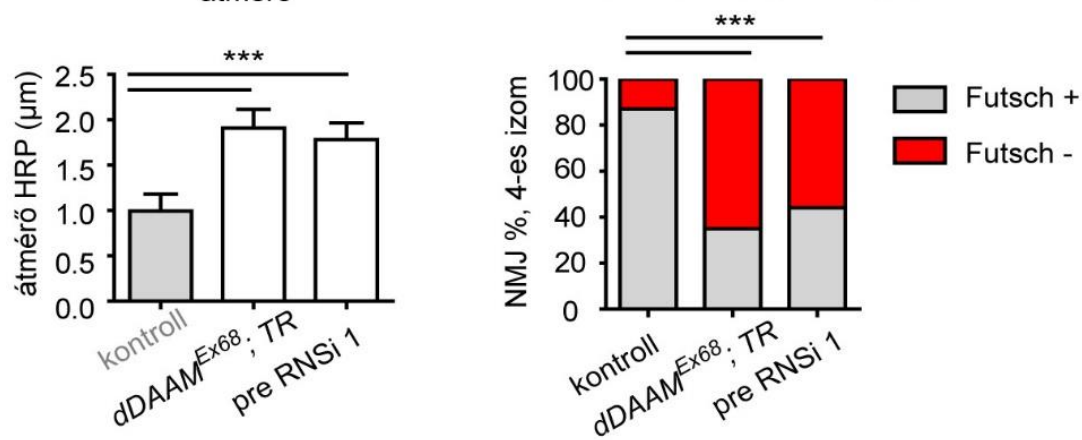

30. ábra A $\boldsymbol{D D A A M}$ mutáns NMJ-ben a preszinaptikus mikrotubulus köteg abnormális szerveződést mutat. (A-C) A mikrotubulus szerveződés vizsgálata konfokális képeken anti-Futsch (zöld) és anti-HRP (magenta) immunfestést használva a 4-es izomhoz tartozó NMJ terminálisokon. A csillagok a képeken az NMJ centrális (a) és terminális (b) részét jelölik, amelyek kinagyítva láthatóak. A mikrotublus rendszer a $d D A A M^{E x 68}$; TR és a preszinaptikus dDAAM RNSi1 (elav-Gal4/+; UASdDAAM-RNSi 1/+) mutáns NMJ-k centrális régiójában ( $\mathrm{Ba}, \mathrm{Ca})$ fragmentált szerveződésủ és gyakran hiányzik a terminális részen $(\mathrm{Bb}, \mathrm{Cb})$ ellentétben a kontrollal (elav-Gal4/+) ( $\mathrm{Aa}, \mathrm{Ab})$. (D) Az interboutonikus régió átméröjének vizsgálata az NMJ centrális részén $(n \geq 15)$. (E) A mikrotubulus szerveződés vizsgálata terminális boutonokban ( $\mathrm{n} \geq 45$ ). A skála mértéke: $5 \mu \mathrm{m}$ (A-C), $2 \mu \mathrm{m}$ (Aa-Cb). Az oszlopok átlagértékeket ábrázolnak a szórások feltüntetésével. *** $\mathrm{p}<0.001$

Annak érdekében, hogy megerősítsük azt, hogy valóban dezorganizált a mikrotubulus szerveződés a $d D A A M$ mutáns preszinaptikus idegvégződésekben, anti-Tubulin immunfestést 
végeztünk, amely közvetlenül jelöli ki a mikrotubulusokat. Habár a mikrotubulus szerveződés nem annyira egyértelmü a terminális boutonokban ezzel a festéssel, az jól látszik, hogy a központi mikrotubulus köteg, nagyon hasonlóan az anti-Futsch festéshez, fragmentált és dezorganizált szerveződést mutat a $d D A A M$ mutáns NMJ-ben (31. ábra).
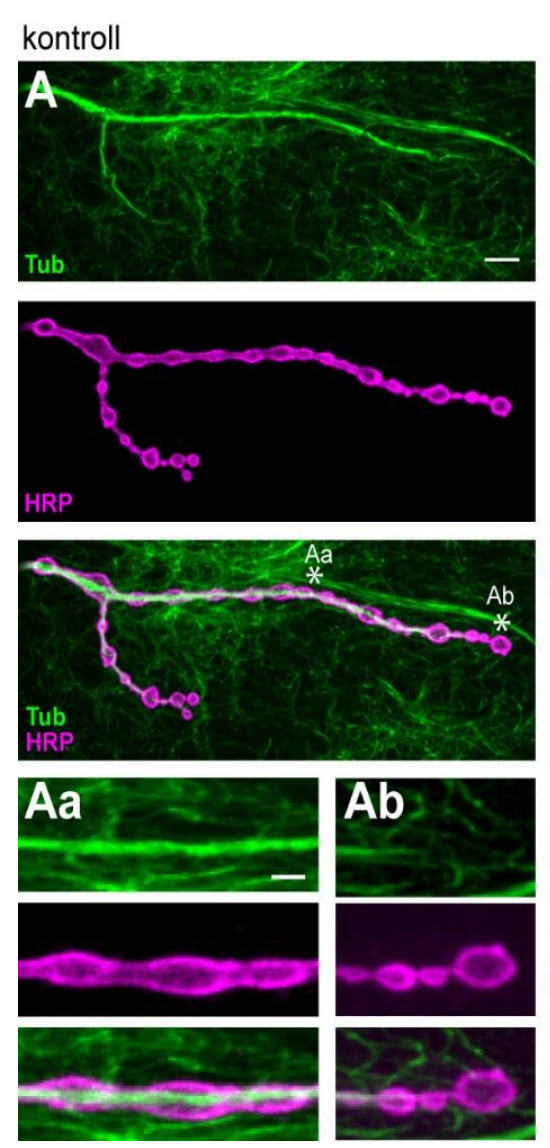
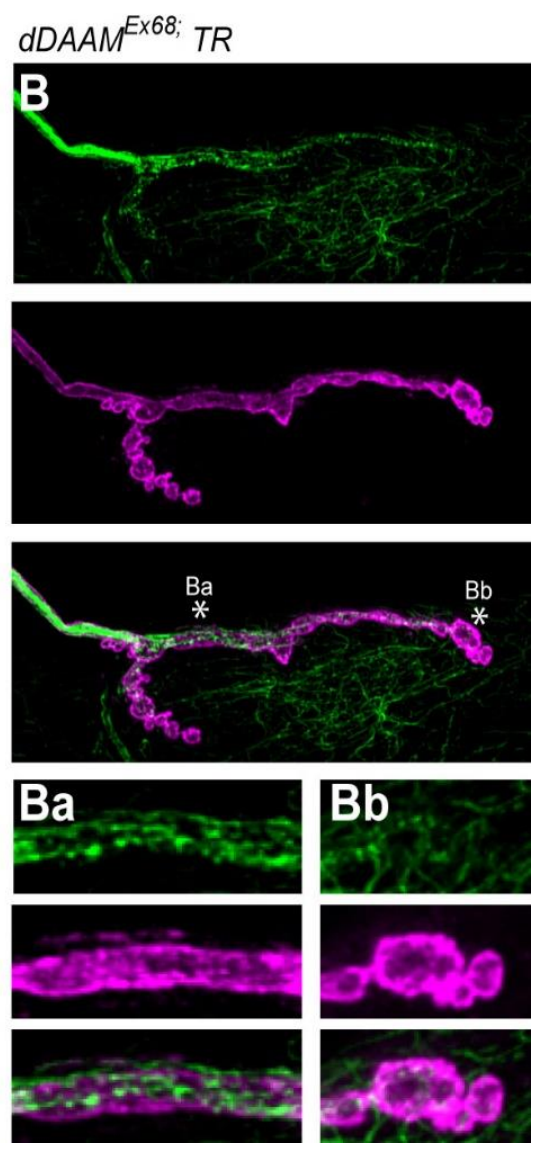

31. ábra A dDAAM hiánya a mikrotubulus szerveződés fragmentálódását okozza.

(A-B) A mikrotubulus rendszer vizsgálata kontroll $\left(w^{1118}\right)$ és $d D A A M$ mutáns NMJ-ben anti-Tubulin (zöld) és anti-HRP (magenta) immunfestést használva. Az A és B panelen lévő csillagok az NMJ centrális ( $\mathrm{Aa}, \mathrm{Ba}$ ) és terminális $(\mathrm{Ab}, \mathrm{Bb})$ részét jelölik. A skála mértéke: $5 \mu \mathrm{m}$ (A, B), $2 \mu \mathrm{m}$ (Aa-Bb).

$\mathrm{Az}$ irodalomban jól ismert tény, hogy a preszinaptikus mikrotubulusok rendezett struktúrájának felbomlása gyakran a szinaptikus komponensek leépülését vagy szinaptikus visszahúzódást (retrakciót) okoz [147]. Annak érdekében, hogy leteszteljük ennek a lehetőségét, megvizsgáltuk a szinaptikus szerveződést mindkét szinaptikus oldalon. A vad típusú NMJ terminálisban a preszinaptikus aktív zóna komplex-szel szemben mindig egy szomszédos glutamát receptor klaszter foglal helyet, így biztosítva ezzel az ingerületátvitelt (32. ábra A) [155]. Ha a glutamát receptor klaszterrel szemben eltünik az aktív zóna komplex, amit szinaptikus visszahúzódásnak hívunk, az azt jelenti, hogy a preszinaptikus aktív zóna leépült vagy felbomlott, mivel a szinapszisképződés kezdetén az egyébként a GluR klaszterrel együtt alakult ki [147]. A szinaptikus retrakció vizsgálatához a preszinaptikus aktív zónákat felismerő anti-Brp és a posztszinaptikus glutamát receptorokat kijelölő anti-GluRIII ellenanyagokat használtuk. A mikroszkópos felvételek alapján a $d D A A M$ null mutáns NMJ- 
ben a szomszédos aktív zóna-glutmát receptor mintázat a vad típushoz hasonló szerveződést mutatott, ami jelzi, hogy a dDAAM fehérje hiánya nem okoz szinaptikus retrakciót (32. ábra B). A fenti eredmények azt sugallják, hogy a dDAAM képes lehet elősegíteni a preszinaptikus mikrotubulusok stabilizálódását, amely nagyon fontos eleme az új bouton képződésnek, de elhanyagolható a funkciója a szinaptikus szerkezet megőrzésében.

\section{kontroll}
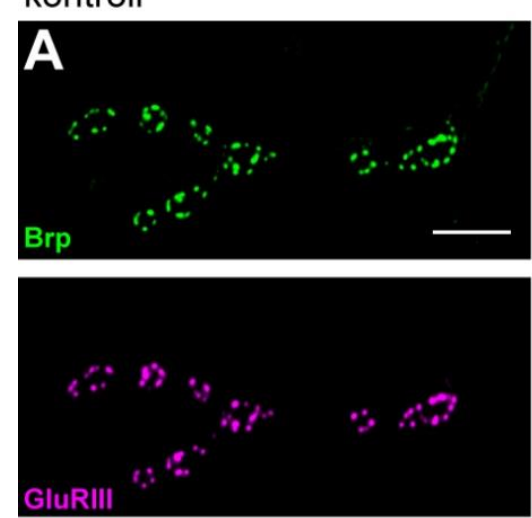

dDAAM ${ }^{E \times 68}$
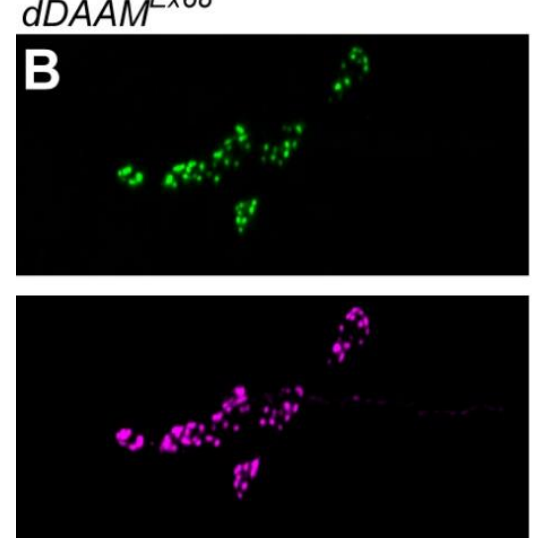
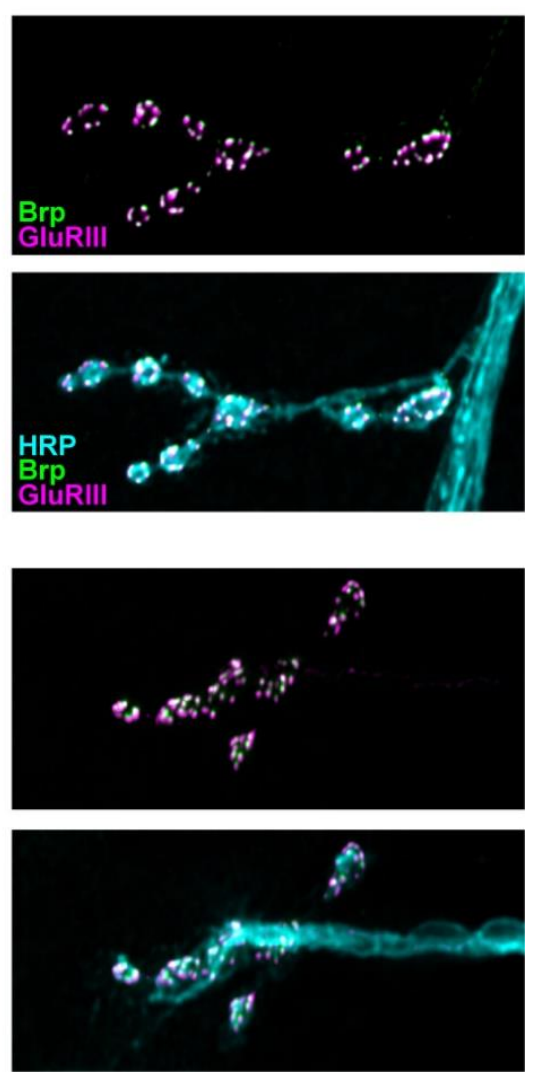

32. ábra A dDAAM hiánya nem okoz szinaptikus retrakciót. A szinaptikus terminálisokban anti-Brp (zöld), anti-GluRIII (magenta) és anti-HRP (cián) immunfestéssel vizsgáltuk az aktív zóna és a Glu receptor klaszter szerveződését. A vad típusú kontrollhoz $\left(w^{1118}\right)(\mathrm{A})$ hasonlóan a $d D A A M^{E x 68}(\mathrm{~B})$ mutánsban a szomszédos Brp-GluRIII mintázat szabályos elrendeződést mutat. A skála mértéke: $5 \mu \mathrm{m}$ (A,B).

A formin típusú fehérjék leginkább ismert tulajdonsága az aktin összeszerelő aktivitásukhoz köthető $[\underline{42}, \underline{44}]$. Emellett egyre több bizonyíték utal arra, hogy a forminok képesek befolyásolni a mikrotubulus organizációt [124]. Számos forminról bebizonyították, hogy in vitro koszedimentációs tesztekben képes kötődni a mikrotubulusokhoz [르, 126-129], valamint sejtes rendszerekben képes elősegíteni a mikrotubulusok stabilizálódását $[\underline{127}, \underline{129}$, $\underline{133-135}, \underline{204]}$. Ezek után adódik a kérdés, hogy a dDAAM, a DAAM formin alcsalád egyetlen Drosophila képviselője, képes-e kötődni a mikrotubulusokhoz. A csoportunk által nemrégen közölt eredménye alapján úgy tűnik a dDAAM fehérje katalitikus FH2 doménje, valamint az extrém C-terminális farok rész egyaránt képes in vitro körülmények között a mikrotubulusokhoz kötődni [129]. Ennek eredményeképpen az a kérdés vetődött fel bennünk, hogy a dDAAM fehérje aktinhoz és/vagy mikrotubulushoz köthető funkciója szükséges a szinaptikus fejlődésben. A kérdés megválaszolásához menekítési kísérleteket végeztünk el 
olyan transzgénekkel, amelyek a teljes hosszúságú dDAAM forma pontmutáns konstrukcióit hordozták.

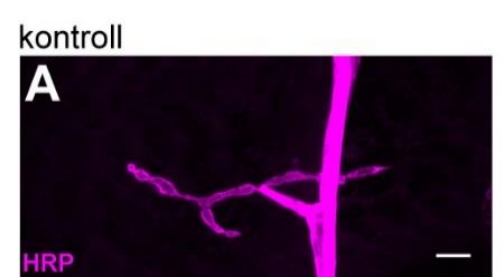
dDAAM ${ }^{\mathrm{Ex} 68} ; N R$

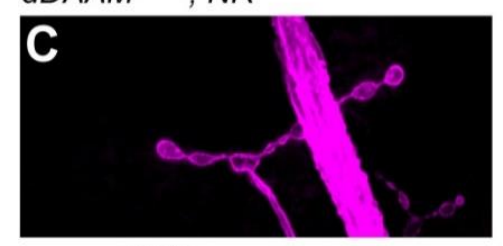

dDAAM ${ }^{E \times 68} ; N R-732$

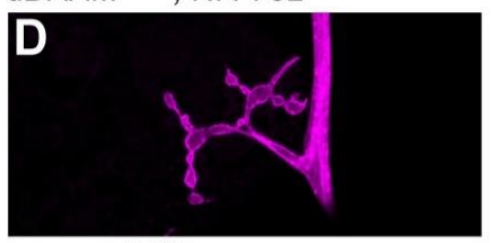

dDAAM ${ }^{E \times 68} ; N R-876-881$

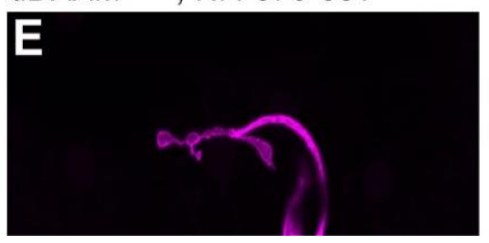

dDAAM ${ }^{E \times 68}$

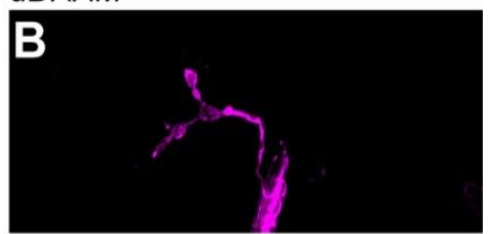

F bouton szám, 4-es izom

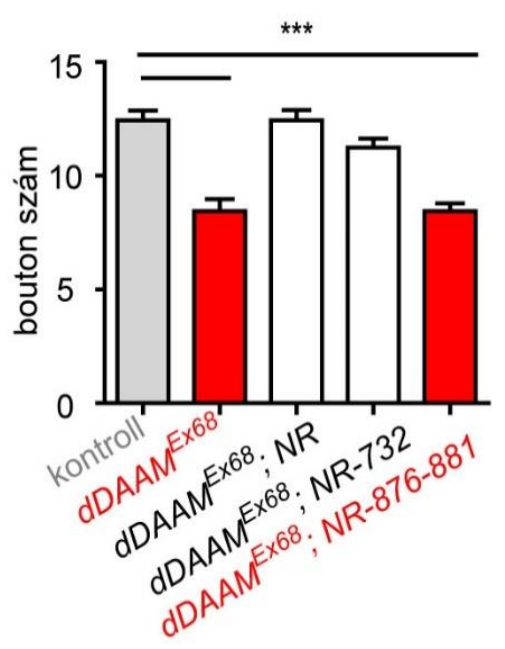

33. ábra A dDAAM aktinkötő funkciója nem szükséges a preszinaptikus bouton képződéshez. (A-F) A $d D A A M^{E x 68}$ menekítése során vad típusú és mutáns FLDAAM konstruktokat termeltünk túl D42-Gal4 driverrel. A 4-es izomhoz tartozó NMJ-ket második stádiumos állatokban vizsgáltuk anti-HRP markerral (magenta) a $w^{1118}$ kontroll törzs (A) használatával. A $d D A A M$ mutáns NMJ fenotípus (B) menekíthető volt a vad típusú $U A S-F L D A A M(\mathrm{C})$ és az egyes pontmutáns $U A S-F L D A A M^{732}$ (D) transzgének használatával. Ezzel szemben a kettős pontmutáns verzió $U A S$ $F L D A A M^{876-881}$ (E) nem volt képes menekíteni a csökkent bouton számot. (F) A bouton szám változásának statisztikai elemzése a menekítési kísérletek során $(\mathrm{n} \geq 15)$. A skála mértéke: $5 \mu \mathrm{m}$ (A-E). *** $\mathrm{p}<0.001$

Az első transzgén esetében (UAS-FLDAAM $\left.M^{I 732 A}\right)$ a 732-es pozícióban lévő izoleucint cseréltük ki alaninra, amely egy olyan, a forminok között konzervált aminosav [우 $\underline{72}, \underline{230}, \underline{231}]$, amely az aktinkötésben esszenciális. A másik transzgenikus konstrukcióban (UAS-FLDAAM ${ }^{\text {K876/881A }}$ ) a 876- és 881-es pozíciókban lévő pozitívan töltött aminosavakat cseréltük ki alaninra, amely ekvivalens az aktin és mikrotubulus kötésre képtelen mDial K989/994A kettős mutánssal [130]. A vad típusú UAS-FLDAAM valamint a mutáns UAS-FLDAAM ${ }^{I 732 A}$ transzgén dDAAM ${ }^{E x 68}$ háttéren $D 42-G a l 4$ motorneuron-specifikus driverrel meghajtva egyaránt képes volt menekíteni a $d D A A M$ null mutáns NMJ fenotípusát (33. ábra A, B, C, D, F). Ezzel ellentétben a kettős mutáns $U A S-F L D A A M^{K 876 / 881 A}$ transzgén nem volt képes helyreállítani (33. ábra $\mathrm{E}, \mathrm{F}$ ) a $d D A A M$ null mutánsra jellemző abnormális NMJ morfológiát és csökkent bouton számot. A kísérletek alapján úgy tünik, hogy a dDAAM NMJ fejlödésben betöltött szerepe elsősorban a mikrotubulus szerveződéshez köthető, míg az aktin összeszerelő aktivitása nem szükséges a bouton képződés elősegítéséhez.

Mivel az aktin inkompetens FLDAAM (UAS-FLDAAM $\left.M^{I 732 A}\right)$ képes volt menekíteni a $d D A A M^{E x 68}$ mutáns állatok NMJ fenotípusát, úgy gondoltuk, hogy az aktin organizáció nem 
érintett a $d D A A M$ mutáns motoraxon terminálisokban. A preszinaptikus F-aktin hálózat valószínüleg egy érzékeny struktúra, amit hagyományos phalloidines festéssel nem lehet megjeleníteni. A preszinaptikus aktin vizualizációjához, ezért az aktin egy formáját az aktin5C::GFP-t termeltettük túl idegrendszer-specifikus driverrel (elav-Gal4) vad és $d D A A M^{E x 68}$ mutáns háttéren, amit aztán anti-GFP festéssel detektáltunk (34. ábra). Az előzetes elgondolásainkkal összhangban, a dDAAM hiánya nem befolyásolta az aktin organizációt, ami megerősítette azt a hipotézisünket, hogy a preszinaptikus kortikális aktin hálózat kialakításában és szervezésében elhanyagolható szerepe lehet a dDAAM-nak.

kontroll
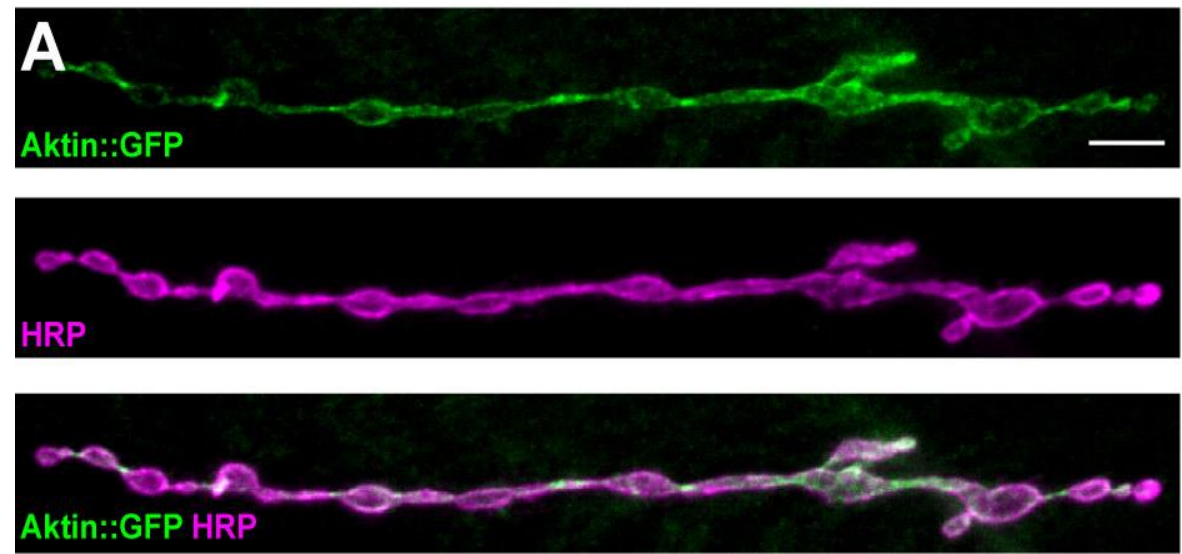

dDAAM ${ }^{E \times 68}$
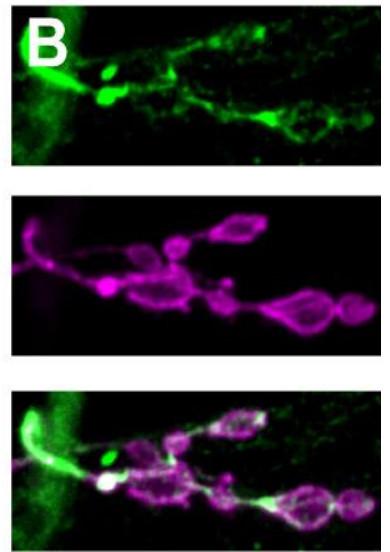

34. ábra A dDAAM null mutáció nem befolyásolja a preszinaptikus aktin szerveződést. (A, B) A konfokális képeken az aktin organizációt kontroll (UAS-aktinGFP/+; elav-Gal4/+) (A) és dDAAM mutáns (dDAAM $M^{E x 68} / Y$; UAS-aktinGFP/+; elav-Gal4/+) (B) axon terminálisokban vizsgáltuk. A preszinaptikus aktin szerveződés megjelenítéséhez anti-HRP (magenta) és anti-GFP (zöld) immunfestést használtunk. A kortikális aktin szerveződés a $d D A A M$ mutáns preszinaptikus idegvégződésekben hasonlóan a vad típushoz a teljes NMJ területén nagyobb strukturális defektusok nélkül. A skála mértéke: $5 \mu \mathrm{m}(\mathrm{A}, \mathrm{B})$.

\section{A konstitutívan aktív C-DAAM elősegíti az új boutonok kialakulását}

A funkcióvesztéses vizsgálatok alapján az NMJ növekedés során a dDAAM elősegíti az új boutonok képződését. A továbbiakban kíváncsiak voltunk arra, hogy ha a fehérje aktivitását megemeljük, akkor annak milyen hatása lesz az NMJ morfológiára vagy a bouton képződésre. Ahogyan a bevezetőben is említésre került, a forminok 7 alcsaládjából 6 a Drosophilában is megtalálható, amelyek legnagyobb csoportja a DAAM alcsaládot is magába foglaló DRF forminok. A DRF forminok közös jellemzője, hogy multidomén szerkezetü, dimerizációra képes fehérjék, amelyek döntő hányada a sejtekben inaktív, mivel az N-terminálison lévő DID és a C-terminálison lévő DAD domén kölcsönhatásba lép egymással kialakítva a molekulában 
egy autoinhibíciós konformációt, amely sztérikusan gátolja a fehérje katalitikusan aktív Cterminális régióját. Egy bizonyos aktivátor jel hatására, pl. Rho típusú kis GTPáz bekötődésével azonban a DID-DAD interakció megszünik, ami lehetővé teszi, hogy az aktin és mikrotubulus kötésben fontos C-terminális régió szabaddá váljon [42, 44]. Korábbi munkáinkból már ismert volt az, hogy az inaktivációért felelős DID domént tartalmazó N-terminális régió eltávolításával, képesek vagyunk egy olyan csonkolt dDAAM fehérjét (C-DAAM) létrehozni, amely konstitutívan aktív formaként viselkedik [으, 228, 231, 232]. A teljes hosszúságú dDAAM forma idegrendszer specifikus (elav-Gal4) túltermelésével a fehérje inaktivációja miatt nem láttunk változást az NMJ morfológiájában, viszont a csonkolt C-DAAM túltermeléssel ugyanazt a drivert használva egy igen jelentős bouton szám növekedést figyeltünk meg az NMJ terminálisokban (35. ábra A-C). A C-DAAM preszinaptikus túltermelésével a motoraxon végződéseken nagy számban megjelentek az újonnan képződő, kisméretü ún. szatellita boutonok (35. ábra $\mathrm{Cb}$ ). A bouton szám emelkedés mellett érdekes módon az interbouton régió kiszélesedett valamint a központi mikrotubulus köteg fragmentált és dezorganizált szerkezetűvé vált (35. ábra $\mathrm{Ca}$ ), ami egyértelmüen funkcióvesztéses hatásról árulkodik.

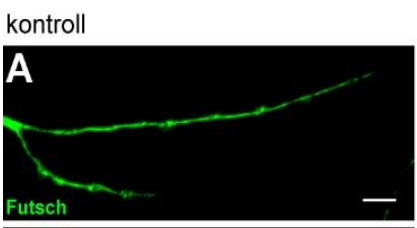

elavG4; UAS-FLDAAM

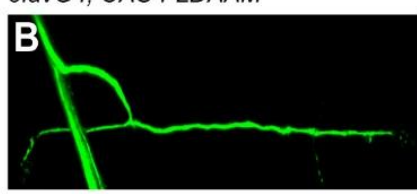

elavG4; UAS-CDAAM
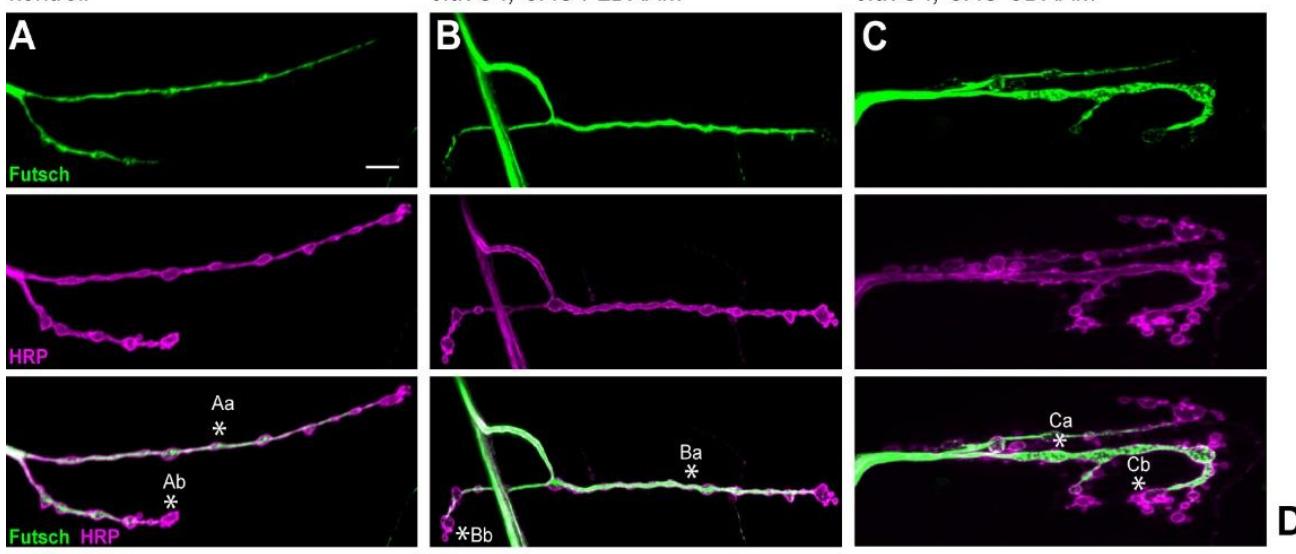

bouton szám
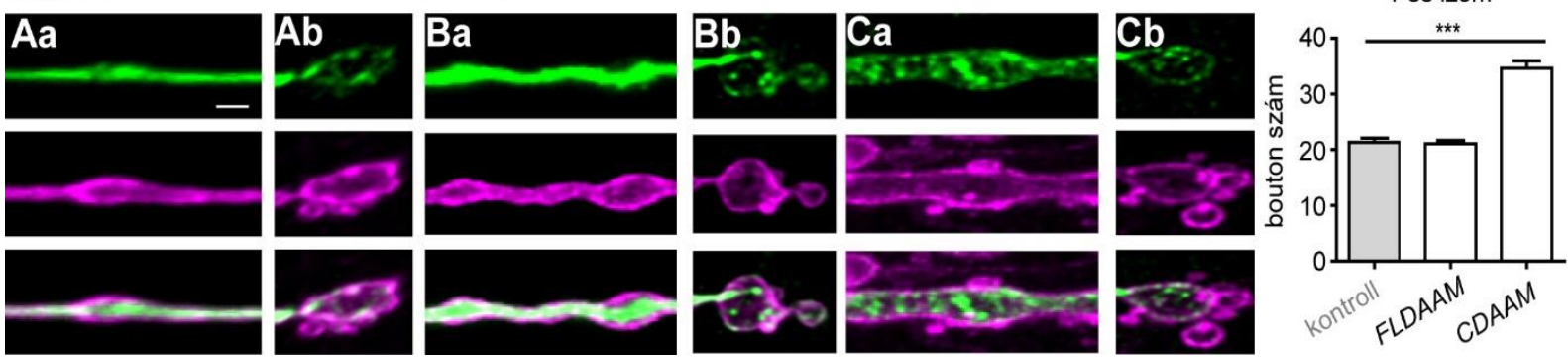

35. ábra A preszinaptikus C-DAAM túltermelése elösegíti az új bouton képződést. (A-C) A preszinaptikus axon terminálisok vizsgálata kontroll (elav-Gal4/+) (A), (UAS-FLDAAM/+; elavGal4/+) (B) és (UAS-C-DAAM/+; elav-Gal4/+) (C) állatokban anti-HRP és anti-Futsch immunfestés használatával. A csillagok az NMJ központi (a) és terminális (b) részét jelölik, amely részek kinagyítva is láthatóak. (D) A bouton szám változása a túltermeléses vizsgálatokban $(\mathrm{n} \geq 25)$. A skála mértéke: $5 \mu \mathrm{m}$ (A-C), $2 \mu \mathrm{m}$ (Aa-Cb). Az oszlopok átlagértékeket ábrázolnak a szórások feltüntetésével. *** p<0.001 
A funkcióvesztéses fenotípuskomponensek megjelenése azért történik, mert feltehetőleg a teljes hosszúságú endogén dDAAM a túltermelt C-DAAM formával dimerizálódik és lokálisan egy dDAAM hiányos állapotot hoz létre. Ezt a hipotézist megerősítik azok a korábbi megfigyeléseink, hogy a C-DAAM tracheaspecifikus túltermelésével szintén funkcióvesztéses fenotípus figyelhető meg, amely hatás csökkenthető, ha a C-DAAM mellett a teljes hosszúságú dDAAM-ot is túltermeljük. Tehát elmondhatjuk, hogy a C-DAAM preszinaptikus túltermelése funkciónyeréses hatással bír a bouton szám vonatkozásában, ami arra utal, hogy a dDAAM elősegíti az NMJ extenziót új boutonok kialakításával.

\section{A dDAAM a Dlar/Trio/Dia jelátviteli egységtől függetlenül szabályozza a szinaptikus bouton képződést}

A formin típusú fehérjék vizsgálata során felmerülhet a kérdés vajon az általunk vizsgált formin funkciója átfed-e más forminok funkciójával. Az irodalomban a forminok közül eddig csak a dia-ról lehet tudni, hogy részt vesz az NMJ fejlődésben [196]. Fontos megemlíteni, hogy a dia esetében leírt NMJ fenotípusok számos tekintetben eltérőek a $d D A A M$ mutánshoz képest. A bouton szám a dia mutáns NMJ végződésekben hasonló csökkenést mutat, mint a $d D A A M$ mutánsokéban, viszont az inter-boutonikus régió kiszélesedése nem látható. Továbbá úgy tünik, hogy a dDAAM-mal ellentétben, a Dia részt vesz a preszinaptikus aktin organizációban, valamint a konstitutívan aktív formája nincs hatással az NMJ morfológiára és a szinaptikus bouton képződésre [196]. A következőekben domináns genetikai kölcsönhatásokban vizsgáltuk, hogy a dDAAM és a Dia között van-e funkcionális redundancia a bouton képződés vonatkozásában. Ahhoz, hogy ezt jól körbejárjuk a dia-n kívül még a Dlar és a trio génekkel is végeztünk domináns genetikai vizsgálatokat, amelyek a dia-val együttmüködnek a szinapszisképződés folyamataiban [196]. Az interakciós tesztekben a $d D A A M^{E x 68} ; T R$ törzset kombináltuk össze a Dlar vagy a dia heterozigóta null mutációival. Megállapítható, hogy sem a Dlar és sem a dia null allélja vad típusú kromoszóma felett nem befolyásolta jelentősen a $d D A A M^{E x 68}$; TR mutánsokra jellemző NMJ morfológiát (36. ábra). 


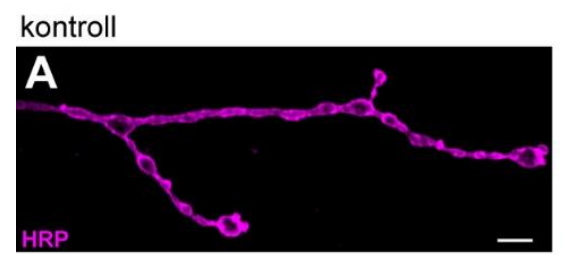

dDAAM ${ }^{E \times 68} ; T R ; d i a^{5} /+$

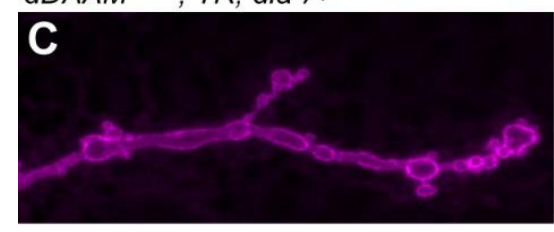

dDAAM ${ }^{E \times 68} ; T R$

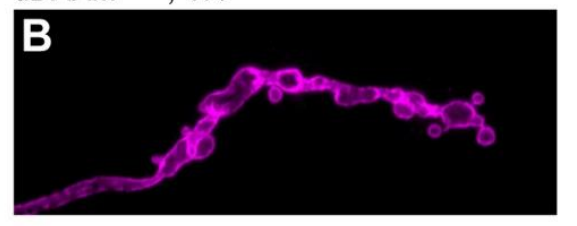

dDAAM ${ }^{E \times 68} ; \operatorname{TR}^{-D^{2}} \mathrm{r}^{13.2} /+$

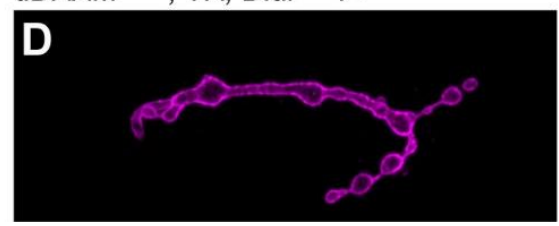

E bouton szám, 4-es izom

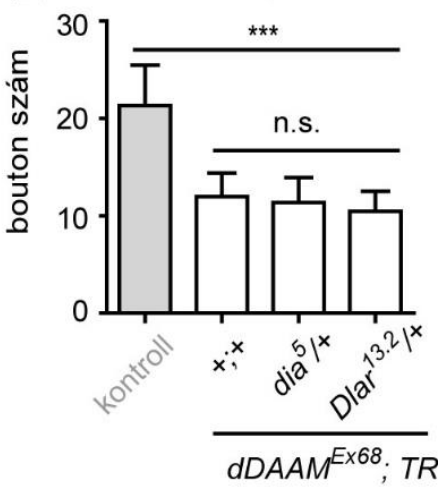

36. ábra A dia és a Dlar nem mutat domináns genetikai interakciót a dDAAM-mal. A vad típusú kontroll $\left(w^{1118}\right)(\mathrm{A})$ és mutáns állatok (B-D) NMJ végződéseinek a vizsgálata a preszinaptikus anti-HRP markerral történt. A genetikai interakciós vizsgálatok során, amikor a $d D A A M^{E x 68}$; $T R(\mathrm{~B}, \mathrm{E})$ állatokat össze kombináltuk a dia és Dlar heterozigóta null mutáns alléljaival, jelentősen nem változott meg a $d D A A M^{E x 68}$; TR genotípusra jellemző csökkent bouton szám (C-E). (E) A bouton szám változása az interakciós vizsgálatokban ( $\mathrm{n} \geq 25)$. A skála mértéke: $5 \mu \mathrm{m}(\mathrm{A}-\mathrm{D})$. Az oszlopok átlagértékeket ábrázolnak a szórások feltüntetésével. $* * * \mathrm{p}<0.001$

Mivel a dia null mutáns allélja kettős heterozigóta formában mind a Dlar mind a trio amorf alléljával erős domináns genetikai interakciót mutatott [196], ezért megvizsgáltuk a heterozigóta $d D A A M$ mutáns állatokat is genetikai interakciós tesztben. A kontroll egyszeresen heterozigóta $d D A A M$, dia és trio mutáns állatokban az elvártaknak megfelelően vad típusra emlékeztető NMJ végződés figyelhető meg (37. ábra D), amely fenotípus számottevő mértékben nem változott meg a kettős heterozigóta $d D A A M /+$; dia/+ és $d D A A M /+$; trio/+ mutáns állatok motoraxon terminálisaiban sem (37. ábra A, B, C, D). Végül kettős homozigóta dDAAM; dia mutáns állatokban akartuk megvizsgálni, hogy a két fehérje egymástól függetlenül müködik-e. Mivel a kettős homozigóta $D D A A M$; dia mutáns kombináció embrió letális, ezért dDAAM/Dia kettős csendesítést végeztem az NMJ-ben idegrendszer specifikus (elav-Gal4) drivert használva (37. ábra A-D). Az egyszeres Dia csendesítés a leírtakhoz [196] hasonló csökkent bouton számot eredményezett (38. ábra B), míg az egyszeres dDAAM csendesítés hasonlóan a korábbi kísérletekhez csökkent bouton számot és bouton fúziós fenotípust okozott (38. ábra C). 

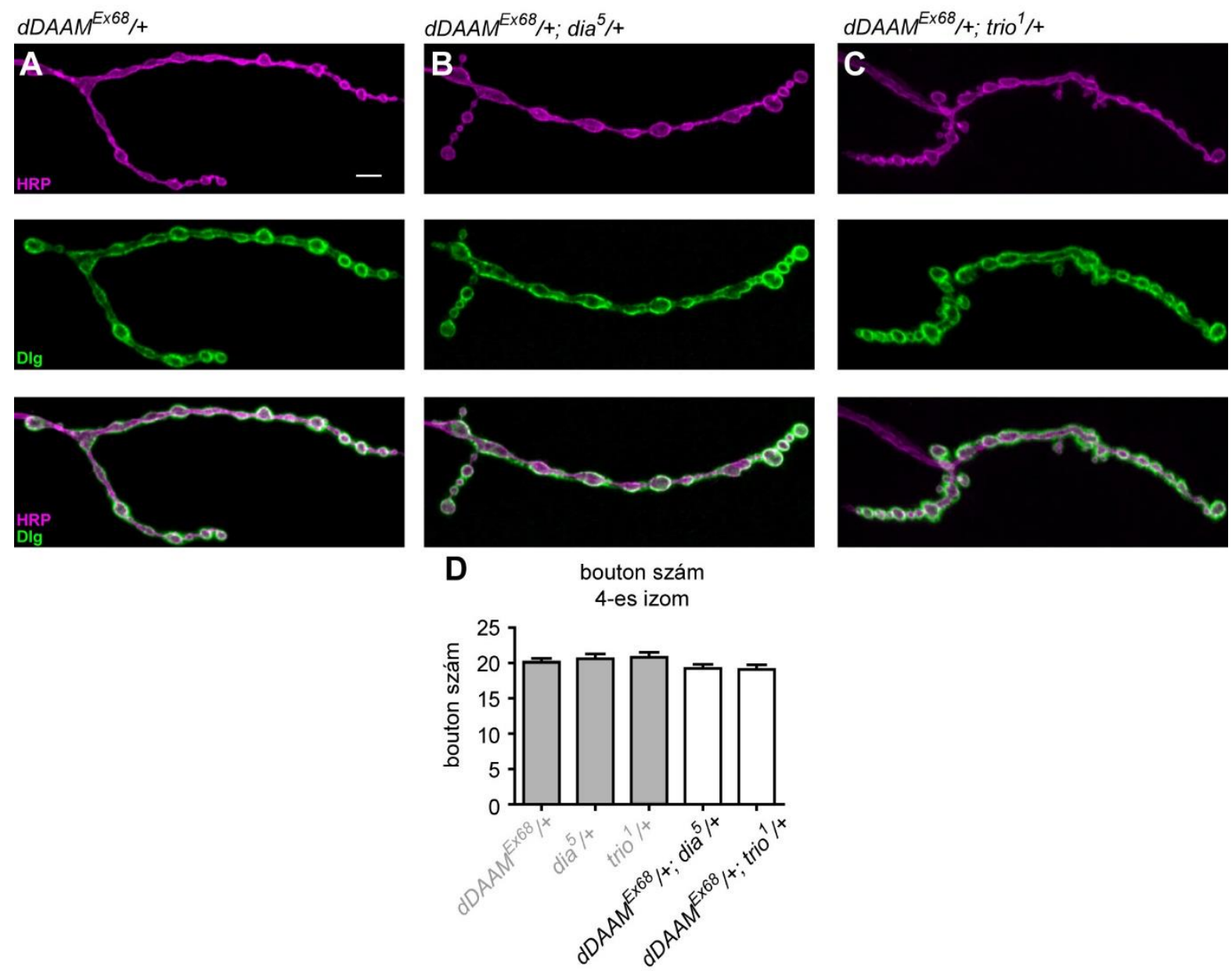

37. ábra A dia és a trio nem mutat genetikai kölcsönhatást a $d D A A M$-mal transzheterozigóta

formában. Az interakcióban szereplő mutáns genotípusok NMJ terminálisait anti-Dlg (zöld) és antiHRP (magenta) szinaptikus markerekkel vizsgáltuk (A-C). A dia (B) és a trio (C) null allélok egy kópiában $d D A A M^{E \times 68}$ heterozigóta háttéren nem változtatták meg a $d D A A M^{E \times 68} /+$, $\mathrm{dia}^{5} /+$ és $\operatorname{trio}^{1} /+$ kontrollokra jellemző bouton számot (D). (D) A bouton szám változása az interakciós vizsgálatokban (E) (n $\geq 25)$. A skála mértéke: $5 \mu \mathrm{m}(\mathrm{A}-\mathrm{D})$. Az oszlopok átlagértékeket ábrázolnak a szórások feltüntetésével. $* * * \mathrm{p}<0.001$

A kettős dDAAM/Dia csendesített állatokban a mutáns NMJ terminálisok morfológiája leginkább a dDAAM funkcióvesztéses fenotípusára hasonlított a kiszélesedő inter-boutonok miatt (38. ábra D). A genetikai interakciós vizsgálatok alapján valószínüleg a Dlar/trio/dia szignalizációs egység a dDAAM-tól függetlenül müködik, viszont a kettős csendesítés azt jelzi, hogy a dDAAM által irányított folyamat a szignalizációs hierarchiák rendszerében lentebb vagy egy szinten van a Dlar/trio/dia szignalizációs komplex-szel. 


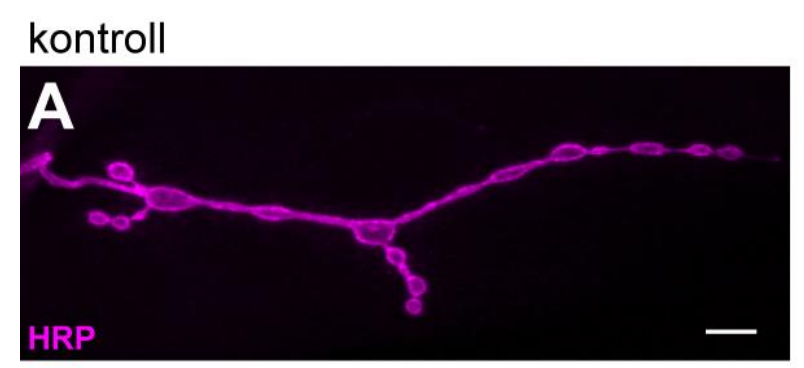

elav-Gal4/+; dDAAM-RNSi1/+

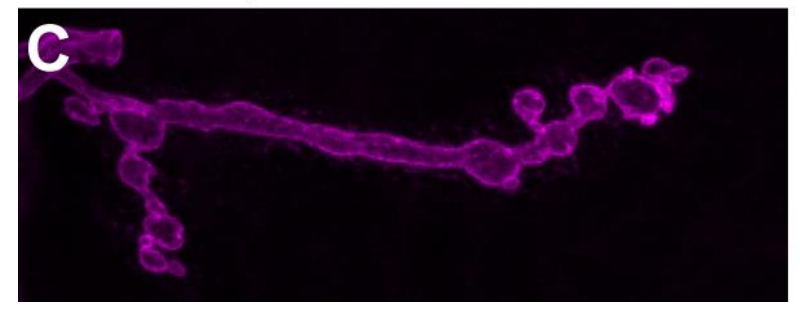

elav-Gal4/+;dia-RNSi/+

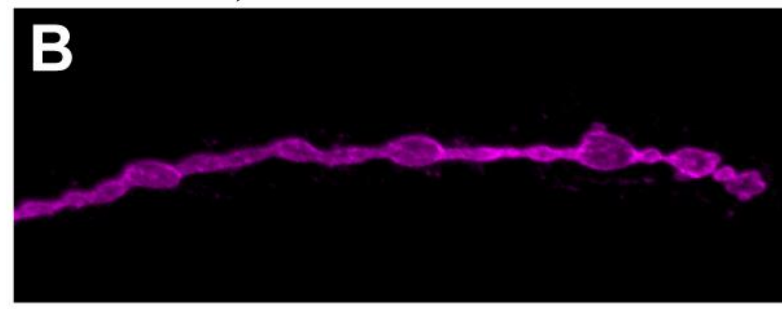

elav-Gal4/+; dDAAM-RNSi1/dia-RNSi

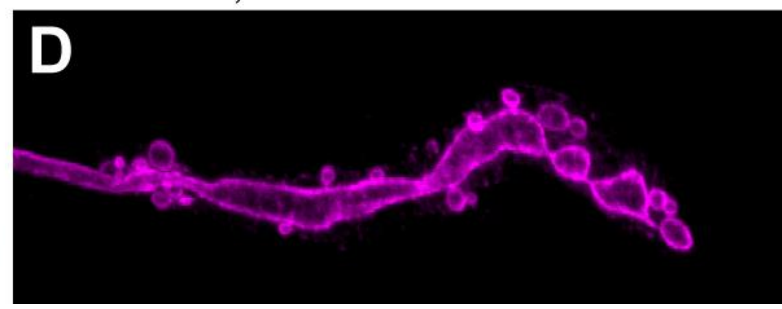

38. ábra A dia-dDAAM szinaptikus csendesítésének vizsgálata NMJ-ben. (A-D) A vizsgálatokban szereplő kontroll (elav-Gal4/+) (A) és formin csendesített (B-D) NMJ terminálisokat anti-HRP (magenta) preszinaptikus markerrel vizsgáltuk. A $d D A A M$ és dia RNSi konstruktokat pánneurális (elavGal4) driver használatával termeltük túl. A preszinaptikus dia csendesítés (elav-Gal4/+; UAS-dia$R N S i /+)$ (B) az irodalmi adatokkal összhangban [196] bouton szám csökkenést idéz elö, míg a dDAAM preszinaptikus csendesítése (elav-Gal4/+; UAS-dDAAM-RNSi/+) (C) hasonlóan a kettős dia-dDAAM csendesítéshez (D) (elav-Gal4/+; dia-UAS-RNSi/UAS-dDAAM-RNSi) csökkent bouton számot és bouton fúziós fenotípust okozott. A skála mértéke: $5 \mu \mathrm{m}$ (A-D).

\section{A $d D A A M$ domináns genetikai interakciót mutat a $w g$ és $A n k 2$ génekkel}

A mikrotubulus rendszer megfelelő szabályozása kulcsfontosságú eleme a szinaptikus bouton képződésnek. Számos génmutációról ismert, hogy tönkreteszi a szabályos mikrotubulus szerveződést, ami befolyásolja a bouton képződést. Habár egyik mutáns esetében sem beszélhetünk arról, hogy a szinaptikus fenotípus teljesen ekvivalens a $d D A A M$ mutánséval, mégis vannak olyan párhuzamok a fenotípusok karakterisztikájában, ami alapján kijelölhetjük azokat a jelátviteli útvonalakat, amelyek együttműködhetnek a dDAAM-mal. A vizsgálatainkhoz szintén domináns genetikai kölcsönhatásokat végeztünk, amelyekben a $d D A A M^{E x 68}$; TR kiindulási törzset kombináltuk össze a mikrotubulus sejtvázszabályozáshoz köthető gének heterozigóta null mutáns alléljaival (39. ábra). 

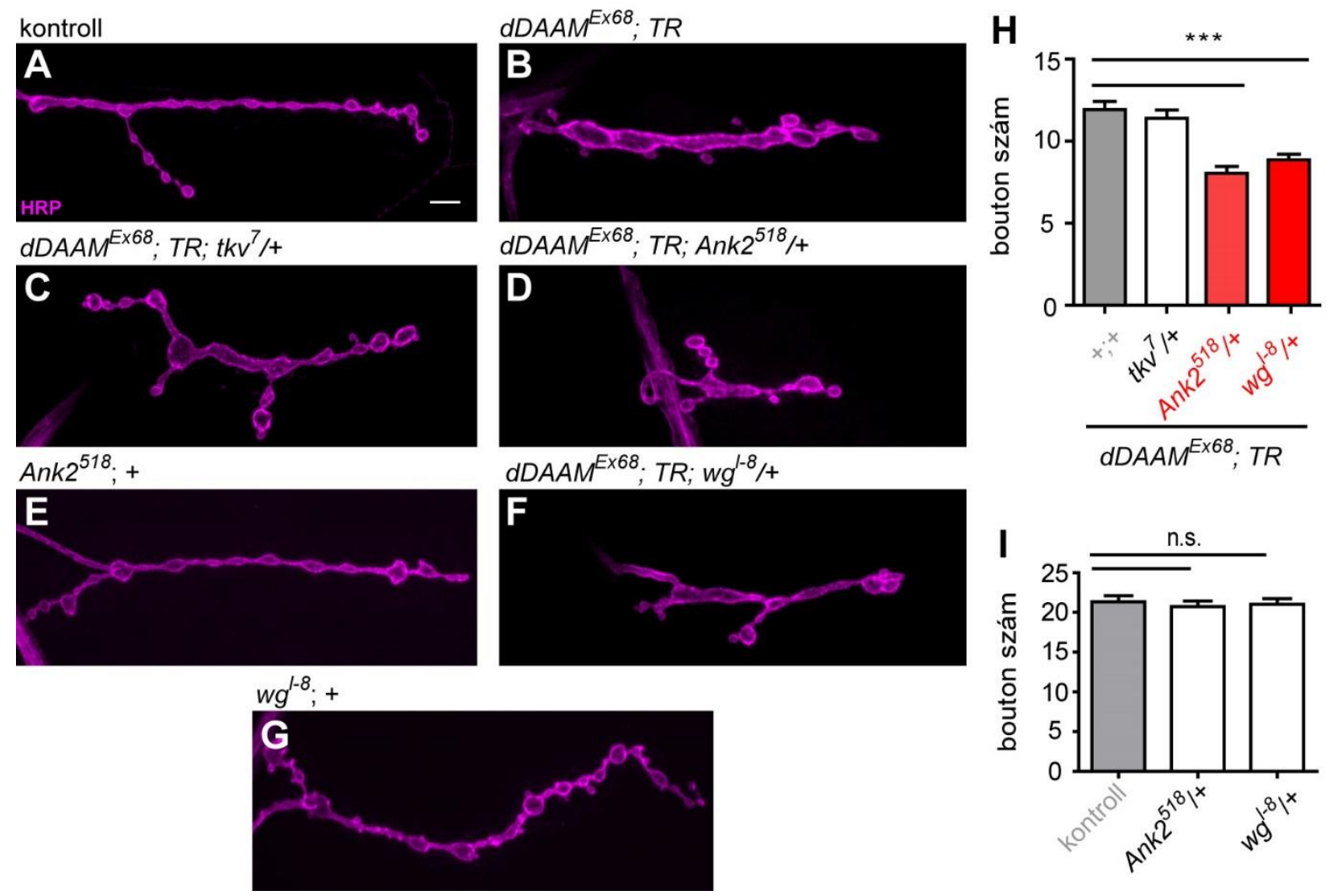

39. ábra A dDAAM domináns genetikai kölcsönhatást mutat az Ank2 és a wg génekkel. A vad típusú kontroll $\left(w^{1118}\right)(\mathrm{A})$ és mutáns állatok (B-G) NMJ végződéseinek a vizsgálata a preszinaptikus anti-HRP markerral történt. A genetikai interakciós vizsgálatok során, amikor a $d D A A M^{E x 68} ; T R(\mathrm{~B}, \mathrm{H})$ állatokat összekombináltuk a $t k v^{7}$ heterozigóta null mutáns alléljaival, jelentősen nem változott meg a $d D A A M^{E x 68} ; T R$ genotípusra jellemző csökkent bouton szám $(\mathrm{C}, \mathrm{H})$. Ezzel ellentétben a $w g^{l 8}$ és $A n k 2^{518}$ null allélek heterozigóta formában jelentősen csökkentették a $d D A A M^{E x 68} ; T R$ mutánsra jellemző bouton számot (D, F, H). (A, E, G, I) Az Ank2 és wg gének egy kópiájának hiánya jelentősen nem befolyásolja a bouton számot a vad típushoz képest. (H, I) A bouton szám változása az interakciós vizsgálatokban $(\mathrm{n} \geq 25)$. A skála mértéke: $5 \mu \mathrm{m}(\mathrm{A}-\mathrm{G})$. Az oszlopok átlagértékeket ábrázolnak a szórások feltüntetésével. $* * * \mathrm{p}<0.001$

Az interakció vizsgálata során először azt vizsgáltuk, hogy egy kópia $t k v, w g$ és Ank2 hiánya befolyásolja-e a $d D A A M^{E x 68} ; T R$ NMJ fenotípusát a bouton szám tekintetében. A $t k v$ amorf allél (39. ábra $\mathrm{C}, \mathrm{H}$ ) nagymértékben nem befolyásolta a $d D A A M$ mutánsra (39. ábra $\mathrm{B}, \mathrm{H})$ jellemző szinaptikus bouton számot, viszont a $w g$ és Ank2 mutációk jelentősen, mintegy 30\%-kal csökkentették azt (39. ábra D, F, H). Más közleményekkel összhangban a wg és az Ank2 mutációk önmagukban heterozigóta formában (39. ábra A, E, G, I) nincsenek hatással a boutonok képződésére [218, 222], ami jelzi, hogy itt valóban egy domináns genetikai kölcsönhatásról lehet szó. Érdekes megemlíteni, hogy korábbi vizsgálatok alapján a dDAAM fehérjét egyértelműen a Wnt/Fz szignalizációhoz kötötték [136, 144, 231]. Ezenkívül a wg és 
Ank2 mutáns NMJ terminálisok bouton szám csökkenést, abnormális mikrotubulus szerveződést valamint bouton fúziót mutatnak [218, 222, 223] , amely fenotípuskomponensek, ha nem is ugyanabban a formában, de megfigyelhetőek a $d D A A M$ mutánsokban is. Később fény derült arra, hogy a $\mathrm{Wg} / \mathrm{Fz} 2$ jelátviteli út az Ank2-vel együtt befolyásolja a preszinaptikus mikrotubulus szerveződést [223]. A fenti irodalmi adatok megerősítik azt a feltételezésünket, hogy a dDAAM együttmüködhet a Wg/Ank2 szignalizációs egységgel.

\section{A dDAAM az Ank2-XL fehérjével együtt szabályozza a preszinaptikus mikrotubulus köteg organizációját}

A genetikai interakciós vizsgálatok után megpróbáltuk episztázis kísérletekkel meghatározni a dDAAM fehérje helyzetét a Wg/Ank2 jeltáviteli útvonalban. Az Ank2 egy downstream eleme ennek a jelátviteli útnak, amelyben adaptor fehérjeként összekapcsolja a kortikális aktin hálózatot a központi mikrotubulus köteggel. Az Ank2 fehérje hiányában a mikrotubulus szerveződés abnormális, a terminális boutonokból a mikrotubulusok eltűnnek, valamint az NMJ gyöngyfüzér struktúrája felbomlik, hosszú megnyúlt fúziós boutonok kialakulásával, amelyekben mikrotubulus aggregáció figyelhető meg [216-218]. Sok esetben az Ank2 mutáns NMJ végződésekben eltünnek a posztszinaptikus glutamát receptorokkal szemközti aktív zóna komplexek jelezve azt, hogy a dezorganizált mikrotubulusok szinaptikus instabilitást okoznak. A hierarchia viszonyok meghatározásához kettős hemi- és homozigóta dDAAM; Ank2 mutánsokat használtunk. Két különböző Ank2 mutáns állt a rendelkezésünkre. Az Ank2-XL $L^{\Delta}$ egy olyan transzpozon excíziós mutáns, amely specifikusan csak az Ank2-XL izoformát távolítja el a rendszerből [218], míg az Ank2 $2^{\text {null }}$ allél esetében az összes Ank2 izoforma érintett [217]. 

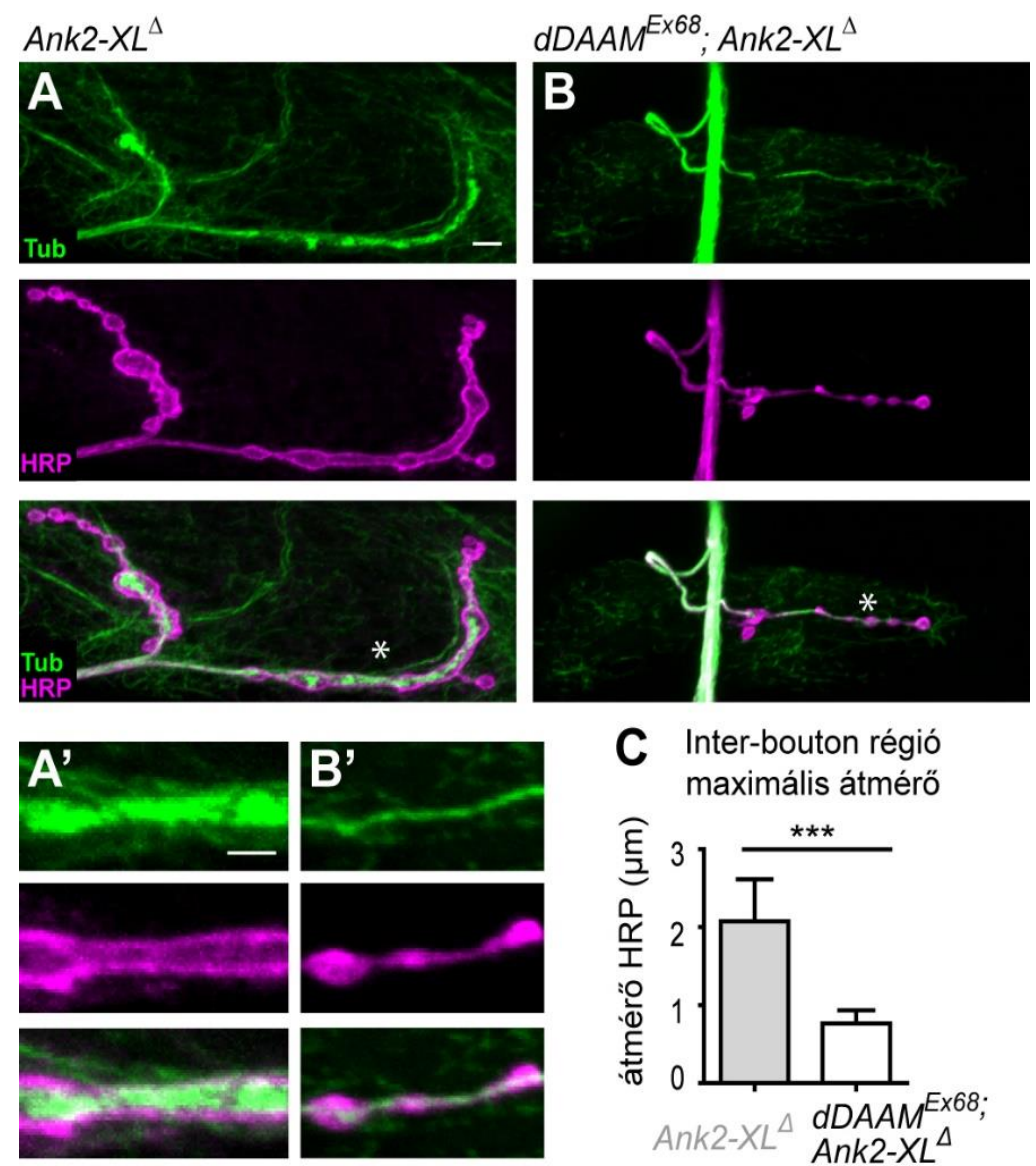

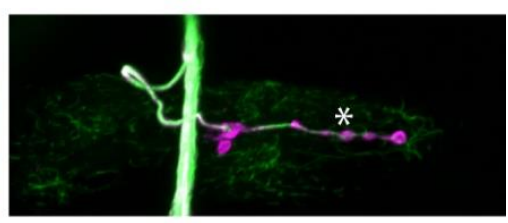

C Inter-bouton régió maximális átmérö

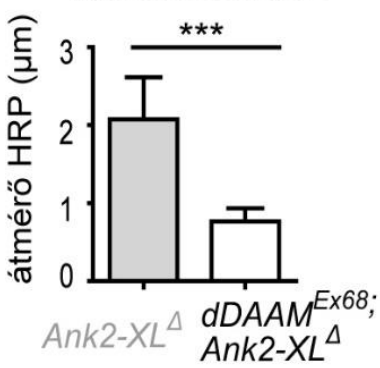

40. ábra Episztázis analízis az Ank2 és a dDAAM között. (AB') A mikrotubulus organizációt az $A n k 2-X L^{\Delta}$ és $d D A A M^{E x 68}$; Ank2-XL mutánsok NMJ terminálisaiban anti-HRP (magenta) és anti-Tubulin (zöld) immunfestéssel vizsgáltuk. (A' és B') A nagy felbontású képeken látható 4-es izom centrális NMJ régiója az A és $B$ paneleken csillaggal jelölve. Az Ank-XL mutáns bouton fúziós és mikrotubulus aggregációs fenotípusát (A, A') a dDAAM hiánya szuppresszálja a kettős mutánsban (B, B'). (C) Az interbouton régió átmérőjének változása $\quad(\mathrm{n} \geq 45) . \quad A \quad$ skála mértéke: $5 \mu \mathrm{m}$ (A, B), $2 \mu \mathrm{m}$ (A', B'). Az oszlopok átlagértékeket ábrázolnak a szórások feltüntetésével. $* * * p<0.001$

Az Ank2-XL hiányában bouton fúzió és az azt kitöltő mikrotubulus aggregáció figyelhető meg (40. ábra A, A', C), viszont szinaptikus instabilitás nem tapasztalható [218] . Meglepő módon a kettős hemi- és homozigóta $d D A A M^{E x 68} ; A n k 2-X L^{\Delta}$ mutánsokban eltünt a mikrotubulus felhalmozódás a preszinaptikus idegvégződésekből, mivel a központi mikrotubulus köteg átmérője közel a vad típussal megegyező lett (40. ábra B, B', C). Továbbá az is érdekes, hogy a $d D A A M$ és az Ank2-XL $L^{\Delta}$ egyes mutánsokban ugyan megfigyelhető volt a szinaptikus bouton összeolvadás, a kettős mutánsokban helyreállt a vad típusú gyöngyfüzérszerü szinaptikus bouton szerveződés. Ha a kettős mutáns analízisben az Ank2-XL $L^{\Delta}$ mutáns allélt az Ank2 $2^{\text {null }}$ allélre cseréltem ki, akkor is hasonló megfigyeléseket tapasztaltunk, ami megerősíti az előző eredménysort (41. ábra). A fenti eredmények arra utalnak, hogy az Ank2 fehérjéhez képest a dDAAM downstream elemként viselkedik. Habár a dDAAM hiánya képes szupresszálni a mikrotubulus aggregációt, ugyanakkor fontos megemlíteni, hogy ez Ank2-XL függő. Ha pedig az Ank2-XL jelen van, akkor a dDAAM hiánya mikrotubulus fragmentációt okoz. Mivel sem a $d D A A M ; A n k 2-X L^{\Delta}$ sem a $d D A A M ; A n k 2^{n u l l}$ kettős mutánsok esetében nem a „tiszta” dDAAM funkcióvesztéses NMJ fenotípus látható, ezért a dDAAM és Ank2 közti kapcsolat valószínűleg sokkal komplexebb, mint egy szimpla lineáris útvonal. 

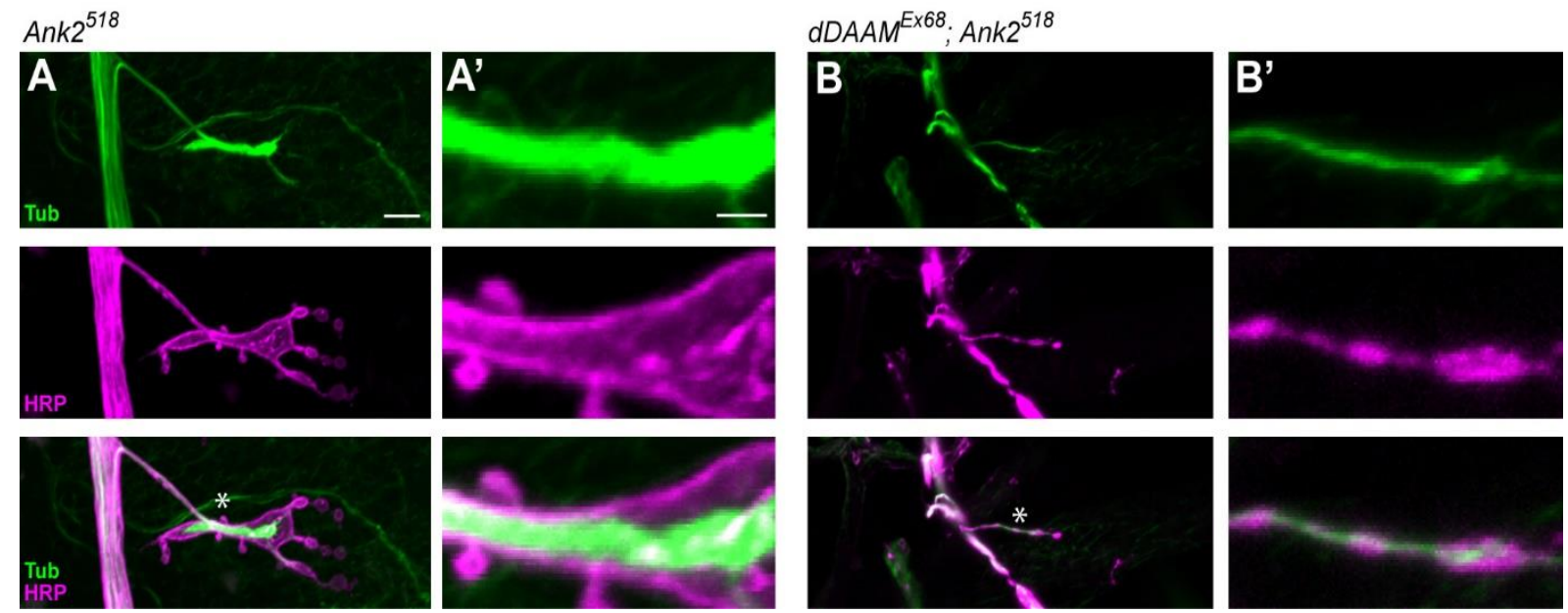

41. ábra Episztázis analízis az Ank2 és a $d D A A M$ között. (A-B') A mikrotubulusok szerveződését az $A n k 2^{518}\left(A n k 2^{n u l l}\right)$ és $d D A A M^{E x 68} ; A n k 2^{518}$ mutánsok 4-es izom NMJ végződéseiben anti-HRP (magenta) és anti-Tubulin (zöld) immunfestéssel vizsgáltuk. (A' és B') A nagy felbontású képeken az NMJ centrális része az A és B paneleken csillaggal jelölve. Az Ank2 null mutáns bouton fúziós és mikrotubulus aggregációs fenotípusát (A, A') a dDAAM hiánya szupresszálja a kettős mutánsban (B, B'). A skála mértéke: $5 \mu \mathrm{m}$ (A, B), $2 \mu \mathrm{m}$ (A', B').

\section{A dDAAM együttműködik a preszinaptikus Wg szignalizáció egyik sejtváz effektor fehérjéjével a Futsch-csal}

Az Ank2 mellett a mikrotubuluskötő Futsch fehérjéről is ismert, hogy a szinaptikus Wg szignalizáció egyik effektor molekulája, és a dDAAM-hoz hasonlóan az Ank2 fehérjével együtt részt vesz a központi mikrotubulus köteg szabályozásában [218, 223]. Hasonlóan az Ank2-höz a Futsch esetében is egyes és kettős $d D A A M / f u t s c h$ mutánsokat vizsgáltunk. A futsch valamint a $d D A A M$ lókusz egyaránt az $\mathrm{X}$ kromoszóma disztális végén helyezkedik el és a két gén egymástól való távolsága $<0,1 \mathrm{Mbp}$, ami azt jelenti, hogy szinte lehetetlen $d D A A M<f u t s c h$ kettős mutánst rekombinációval létrehozni. Így elhatároztuk, hogy a CRISPR/Cas9 technika segítségével új futsch null mutációt hozunk létre vad típusú és $d D A A M^{E x 68}$ null mutáns háttéren is. A Flybase predikció alapján az első kódoló exon az összes Futsch izoformában megtalálható, ezért úgy döntöttünk, hogy az első kódoló exonban létrehozunk egy 300 bp-os deléciót, amely frameshiftet okoz a génen belül. Az új 300 bp-os deléciót hordozó futsch ${ }^{C R 13}$ allélt Western blottal és immunfestéssel teszteltem le. Sem a Western bloton, sem az immunfestésen nem detektálható a fehérje, ezért kijelenthető, hogy a futsch ${ }^{C R I 3}$ egy protein null allél (42. ábra A, B, C). Az új futsch ${ }^{C R 13}$ allél a korábbi futsch ${ }^{K 68}$ null allélhoz hasonlóan csökkent bouton számot, kismértékű bouton méret növekedést és vad típusú mikrotubulus szerveződést mutat az NMJ 
végződésben (42. ábra D, D', F). Ezzel ellentétben a hemizigóta $d D A A M^{E x 68}$, futsch ${ }^{C R 13}$ kettős mutáns NMJ terminálisokban csökkent bouton szám, bouton fúzió, valamint szakadozott mikrotubulus kötegek jelentek meg (42. ábra E, E', F), ami nagyon hasonlít a $d D A A M$ fenotípusra. A fenti kísérletek alapján a $D D A A M$ episztatikus a futsch-hoz képest.
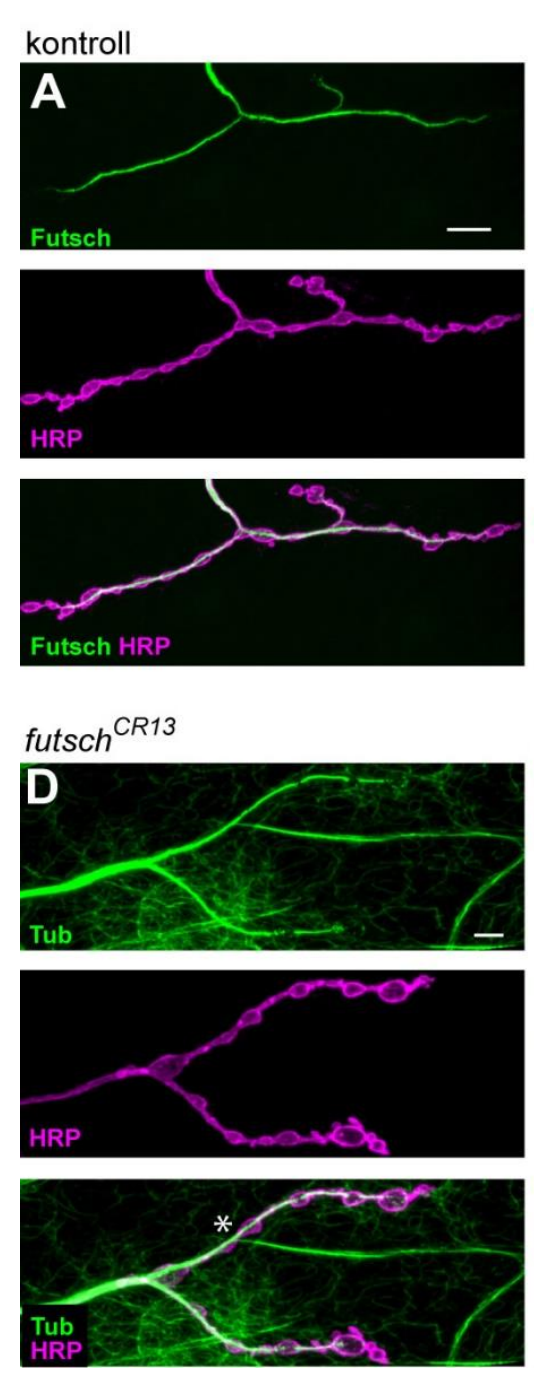
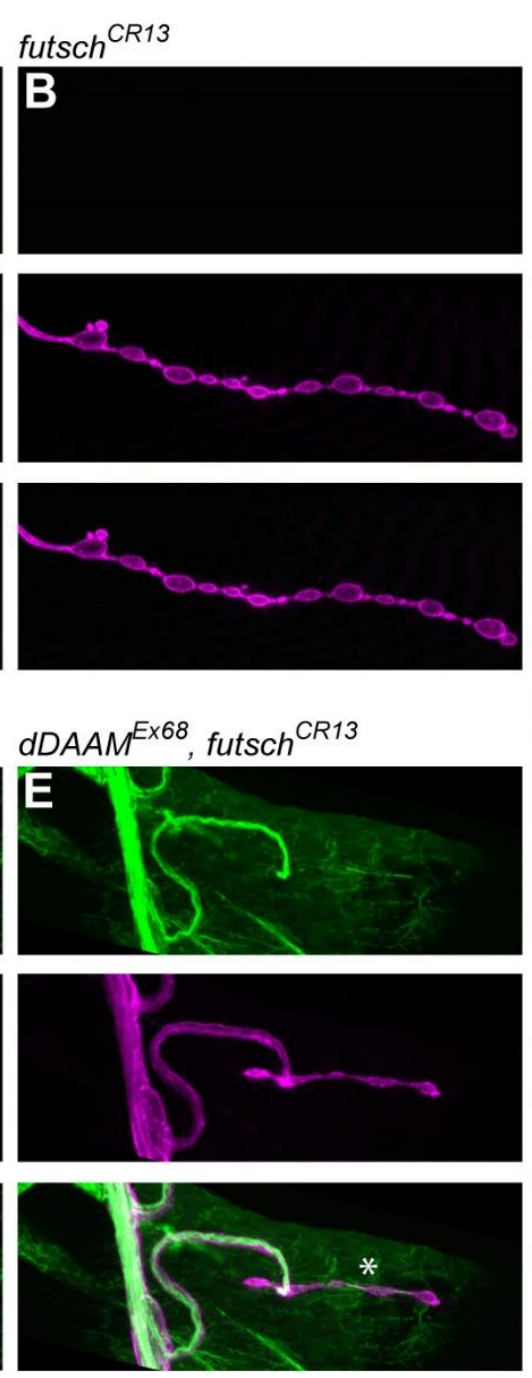
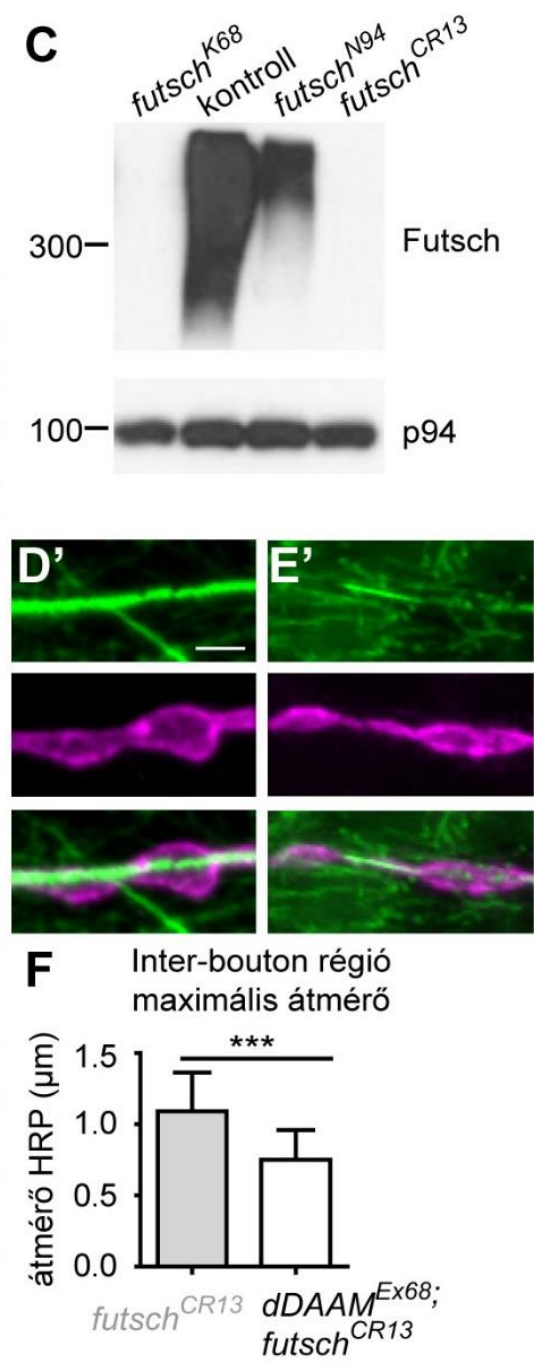

42. ábra A dDAAM episztatikus a futsch-hoz képest a bouton képződés során. Az új futsch CRISPR allél (B) esetében az anti-Futsch (zöld) immunfestés szinte teljesen eltünik a kontrollhoz $\left(w^{1118}\right)$ (A) képest a 4-es izom NMJ végződésében. Az immunfestéshez hasonlóan a Western blot kísérletben az anti-Futsch jel alig detektálható a futsch ${ }^{C R 13}$ mintában (C). A Western blotban a minták fehérje mennyiségének az összehasonlításához az anti-p94 ellenanyagot használtuk kontrollként. (D, D') A futsch $^{C R 13}$ mutáns NMJ végződésekben (D, D') enyhe bouton szám csökkenés figyelhető meg, míg a kettős mutáns $\left(d D A A M^{E x 68}\right.$, futsch $\left.{ }^{C R 13}\right)$ (E, E') esetében a $d D A A M$ fenotípusra emlékeztető fragmentált, szakadozott mikrotubulusok kiszélesedő inter-boutonikus régióval. (D, E) A csillagok a nagy felbontású képek helyeit jelölik az NMJ középső harmadánál. Az inter-boutonikus régió átmérőjének változása a mutáns NMJ-k centrális részén (F) (n $\geq 45)$. A skála mértéke: $5 \mu \mathrm{m}(\mathrm{D}, \mathrm{E}), 2 \mu \mathrm{m}$ (D’, E'). Az oszlopok átlagértékeket ábrázolnak a szórások feltüntetésével. $* * * \mathrm{p}<0.001$ 
A

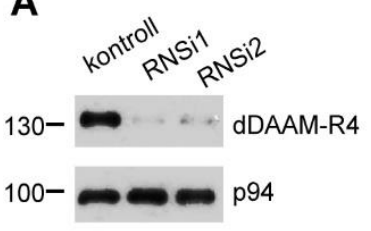

B
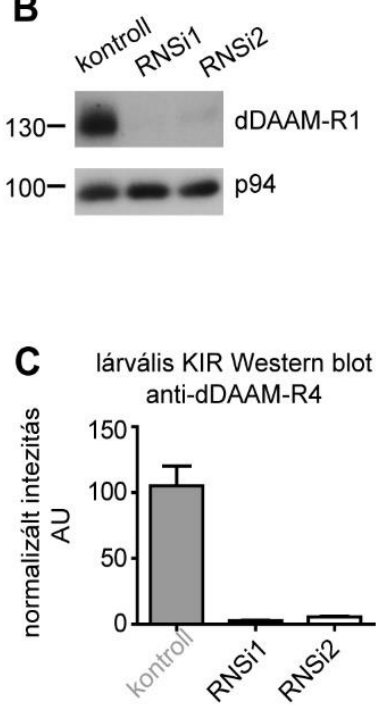

kontroll
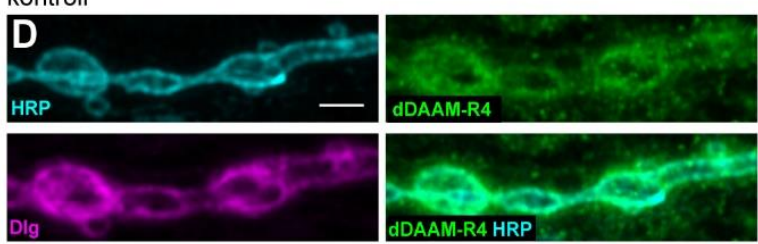

dDAAM-R4 HRP

elav-Gal4, mef2-Gal4/+; dDAAM-RNSi 1
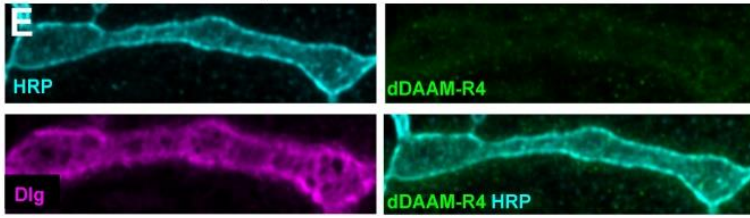

kontroll
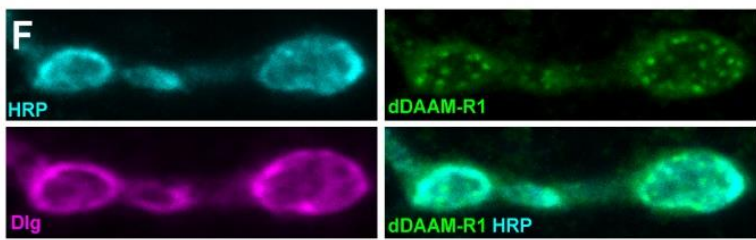

dDAAM-R
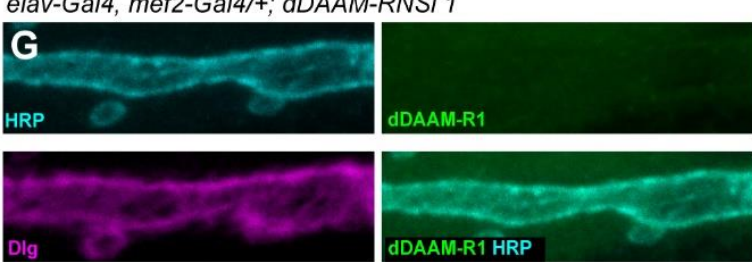
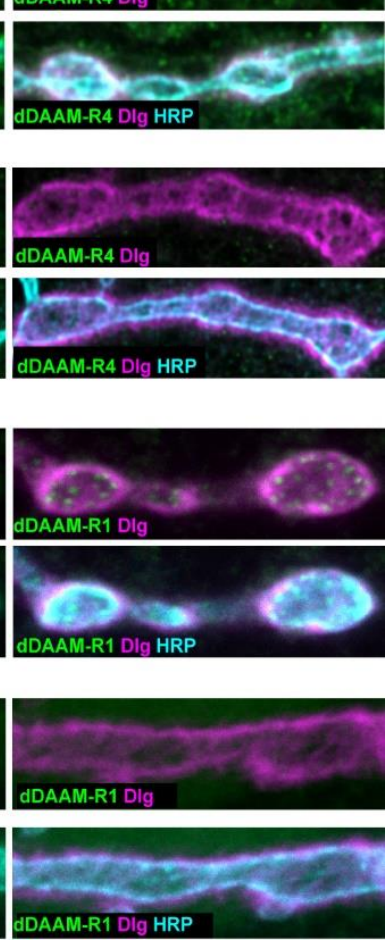

43. ábra A dDAAM R1 és R4 ellenanyagok specifikusságának a vizsgálata. (A-C) A Western blot kísérletek alapján a dDAAM specifikus RNSi vonalak elav-Gal4 driver használatával (elav-Gal4/+; UAS-dDAAM-RNSi 1/+ és elav-Gal4/+; UAS-dDAAM-RNSi 2/+) nagy hatékonysággal csendesítik a dDAAM gént a KIR-ben. A 130 kDa-os magasságban lévő jel mindkét ellenanyag használatával szinte teljesen eltünik. A kontroll (elav-Gal4, mef2-Gal4/+) állatokban látható kortikális (D) és pöttyszerü (F) dDAAM (zöld) felhalmozódás szinte teljesen eltünik a pre- és posztszinaptikusan dDAAM csendesített állatokban (elav-Gal4, mef2-Gal4/+; UAS-dDAAM-RNSi 1/+) (E, G), ami nem befolyásolta az antiHRP (cián) és anti-Dlg (magenta) szinaptikus markerek festődési mintázatát. Az oszlopok átlagértékeket ábrázolnak a szórások feltüntetésével $(C)$. $\mathrm{n} \geq 10$. A skála mértéke: $3 \mu \mathrm{m}(\mathrm{D}-\mathrm{G})$.

A dDAAM szinaptikus lokalizációjának vizsgálatához a dDAAM-R1 és R4 poliklonális nyúl ellenanyagokat használtam. Ha a két ellenanyagot megvizsgáljuk lárvális NMJ-ben, akkor a dDAAM-R4 ellenanyag kortikális felhalmozódást (43. ábra D), míg a dDAAM-R1 ellenanyag, meglepő módon aktív zóna mintázatra emlékeztető pöttyszerü mintát mutat (43. ábra F). Annak érdekében, hogy meggyőződjünk arról, hogy mindkét ellenanyag specifikusan müködik, további kontroll kísérleteket végeztem el. Először RNSi segítségével a pre- és posztszinaptikus oldalon egyaránt csendesítettem a dDAAM-ot elav-Gal4, mef2-Gal4 driver 
kombináció segítségével, majd mindkét ellenanyaggal immunfestéseket végeztem a mutáns NMJ terminálisokon. A dDAAM csendesített NMJ terminálisokban mindkét ellenanyaggal csak egy alig detektálható gyenge háttérfestődés látszik, ami az ellenanyagok specifikusságára utal (43. ábra E, G). Az immunfestés után kíváncsiak voltunk arra, hogy az ellenanyagok Western bloton is müködnek-e. A Western blot kísérletekhez egy vad és két dDAAM RNSi mintát használtam. Az előhívott filmeken egyértelműen látszik, hogy a vad típusú mintában a 130kDa-os tartományban detektálható jel szinte teljesen eltünik a dDAAM RNSi mintákban, míg az összfehérje mennyisége nem változik. Ez alapján elmondható, hogy mindkét ellenanyag specifikusan felismer egy a Flybase prdedikciónak megfelelö körülbelül 130 kDa-os fehérjét (43. ábra A, B, C). Korábbi kísérleteink alapján elmondható, hogy a dDAAM-R1 ellenanyag specifikus az embrionális trachearendszerben [228], a dDAAM-R4 ellenanyag pedig az embrionális KIR-ben [232]. Kíváncsiak voltunk arra, hogy a dDAAM-R1 specifikus-e a KIRben és a dDAAM-R4 a tracheában, illetve azt is meg akartuk vizsgálni, hogy valamelyik ellenanyag esetleg csak az aktív vagy inaktív konformációval rendelkező dDAAM fehérjét ismer-e fel. A vizsgálatainkhoz 15-17 stádiumos $w^{1118}, d D A A M^{E x 68}$ és $d D A A M^{E x 68} ; T R$ embriókat használtunk. Az embrionális KIR vizsgálatához minden esetben BP102 ellenanyagot használtunk KIR axonális markerként. A dDAAM-R1 és dDAAM-R4 ellenanyag egyaránt specifikusan kijelölte a KIR-t vad típusú embriókban (44. ábra A, D), amelyben a két ellenanyag nagymértékü átfedést mutat a BP102 mintával. Ezzel szemben a $d D A A M^{E x 68}$ és dDAAM ${ }^{E x 68}$; TR mutáns embriókban a dDAAM-R1 és dDAAM-R4 festődés szinte teljesen eltünik a KIR axonokból (44. ábra B, C, E, F). Az is jól megfigyelhető, hogy a $d D A A M^{E x 68}$; TR embriókban az FLDAAM kizárólag a tracheában fejeződik ki, amelyet a dDAAM-R1 és dDAAM-R4 ellenanyag egyaránt felismer (44. ábra C, F). 


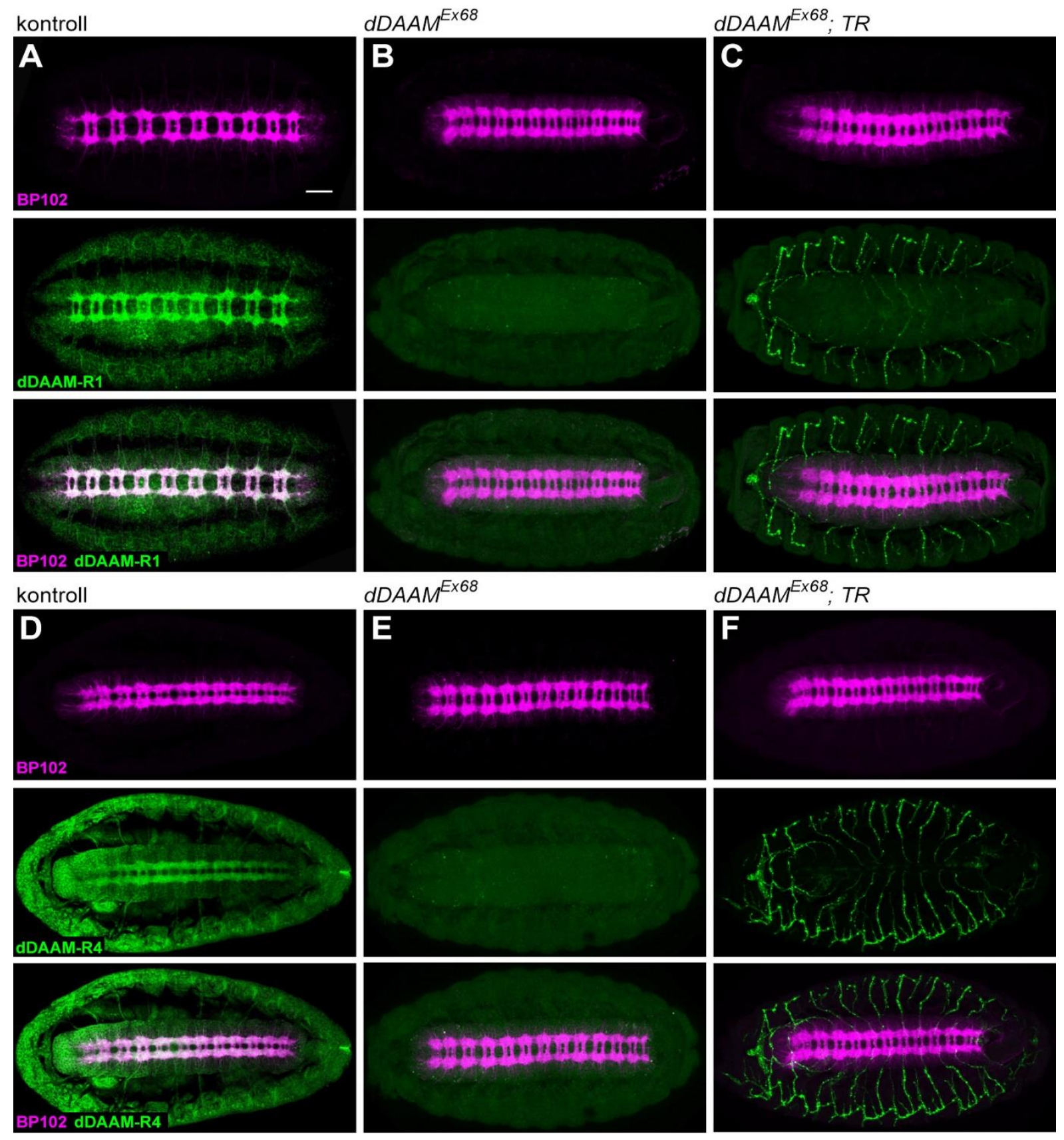

44. ábra A dDAAM-R1 és R4 ellenanyagok festési mintázatának összehasonlítása embrionális hasi idegkötegben (HIK). (A-F) Konfokális képeken hasonlítottuk össze a dDAAM-R4 és R1 ellenanyagok (zöld) festési mintázatát 15-17 stádiumos kontroll (A, D) és $d D A A M$ mutáns (B, C, E, F) embriókban. Az R1 (A) és R4 (D) ellenanyagok nagy specifikusággal jelölik ki a HIK-et a vad típusú embriókban. A HIK kijelölésére a BP102 axonális markert (magenta) használtuk, amelynek mintázata nagyrészt átfed az R1 és R4 ellenanyagokkal. (B, E) A $d D A A M^{E x 68}$ mutánsokban a dDAAM jel mind az R1 mind az R4 ellenanyag esetében szinte teljesen eltűnik az embriók teljes területéről, míg a $d D A A M^{E x 68} ; T R$ embriókban $(\mathrm{C}, \mathrm{F})$ szinte kizárólag a tracheában detektálható a dDAAM jel, a BP102 marker alapján a HIK axonok dDAAM negatívak. A skála mértéke: $20 \mu \mathrm{m}$ (A-F). 

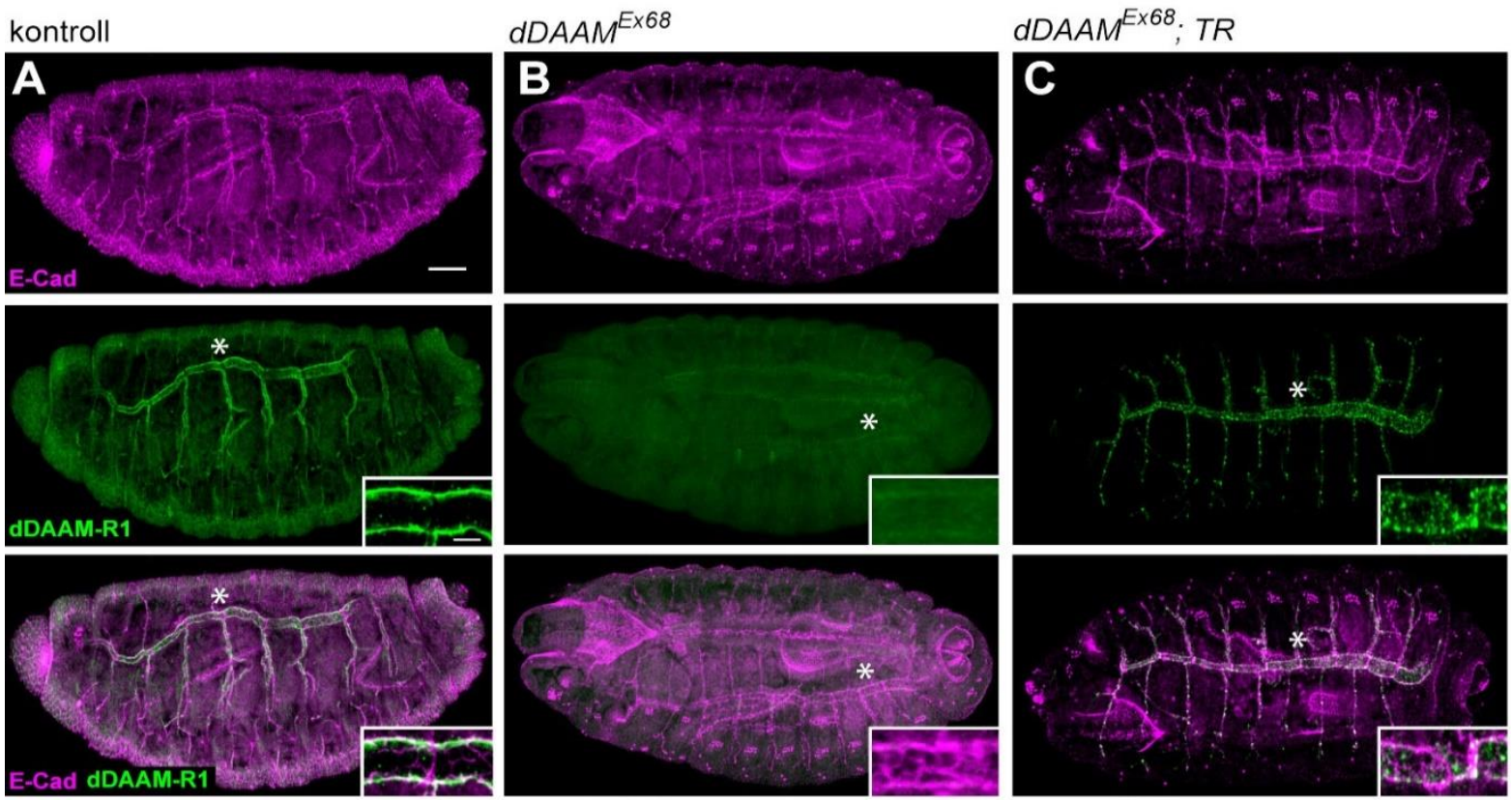

kontroll

dDAAM ${ }^{E \times 68}$
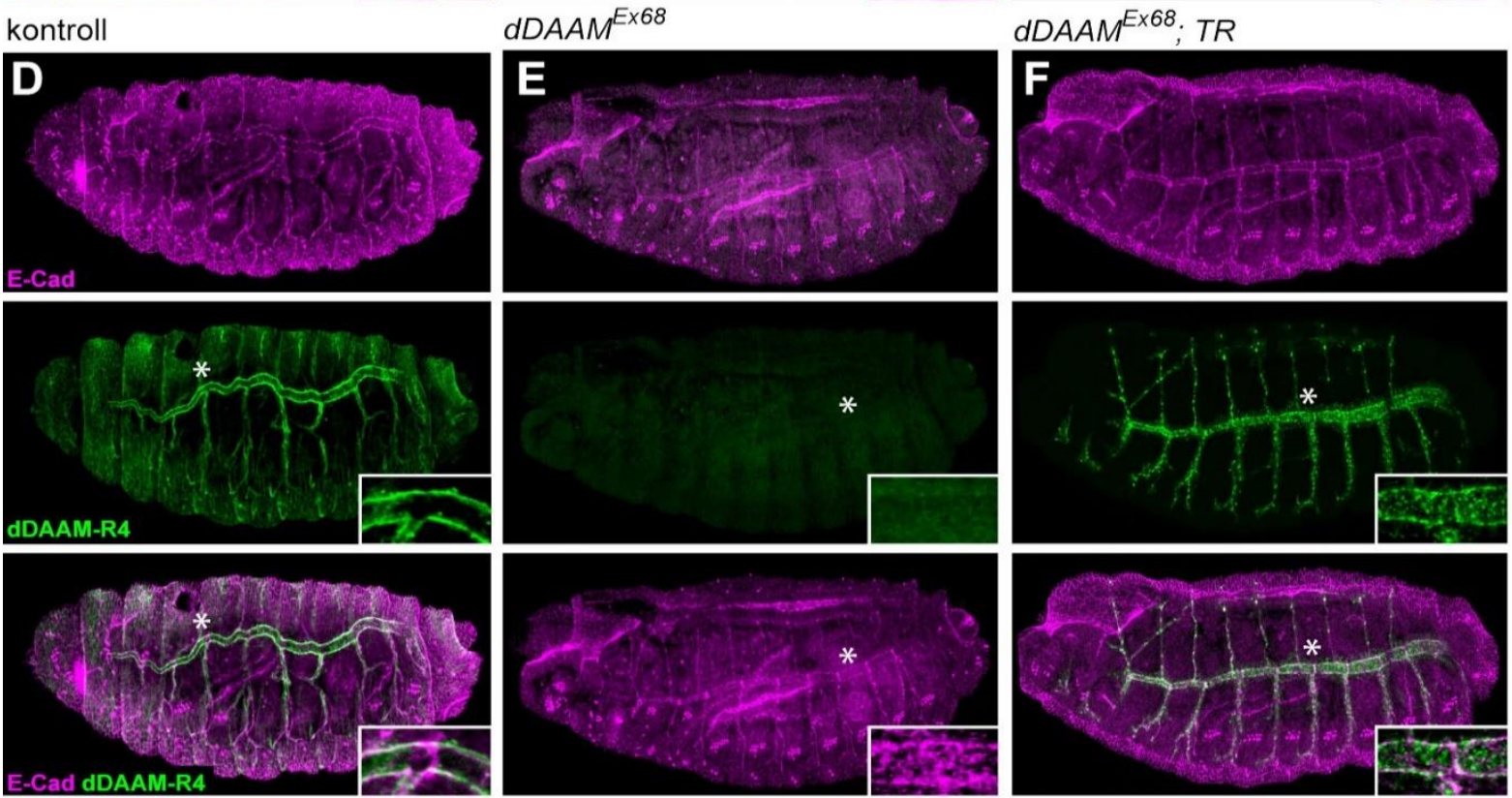

45. ábra A dDAAM-R1 és R4 ellenanyagok festési mintázatának összehasonlítása embrionális

trachearendszerben. (A-F) Konfokális képeken hasonlítottuk össze a dDAAM-R4 és R1 ellenanyagok (zöld) festési mintázatát 15-17 stádiumos kontroll (A, D) és $d D A A M$ mutáns $(\mathrm{B}, \mathrm{C}, \mathrm{E}, \mathrm{F})$ embriókban. Az R1 (A) és R4 (D) ellenanyagok nagy specifikusággal jelölik ki a tracheaágakat a vad típusú embriókban, valamint a nagy felbontású képeken (a csillagok a kinagyított trachea-elágazások helyeit jelzik), amelyek a panelek jobb alsó sarkában helyezkednek el, a dDAAM nagyrészt szubkortikális felhalmozódást mutat. A trachea kijelölésére az anti- E-Cad ellenanyagot (magenta) használtuk, amely az embrionális sejthatárok markere. (B, E) A $d D A A M^{E x 68}$ mutánsokban a dDAAM jel mind az R1 mind az R4 ellenanyag esetében szinte teljesen eltünik az embriók teljes területéröl, (C, F) míg a $d D A A M^{E x 68}$; $T R$ embriókban szinte kizárólag a tracheában detektálható a dDAAM jel. A $d D A A M^{E x 68} ; T R$ nagy felbontású képein pöttyökben megjelenő dDAAM aggregátumok láthatóak mindkét ellenanyaggal. A skála mértéke: $20 \mu \mathrm{m}$ (A-F), $5 \mu \mathrm{m}$ (nagy felbontású képek a panelek sarkában A-F). 
Az embrionális trachearendszer vizsgálatához az E-Cad ellenanyagot használtuk markerként, amely az embrionális sejthatárokat jelöli ki. A vad típusú embriókban a dDAAMR1 és dDAAM-R4 ellenanyag specifikusan kijelöli az embrionális tracheahálózatot, amelynek mintázata leginkább szubkortikális (45. ábra A, D). A $d D A A M^{E x 68}$ embriókban a dDAAM-R1 és dDAAM-R4 festés szinte teljesen eltünik az egész embrióból (45. ábra B, E), viszont a $d D A A M^{E x 68} ; T R$ embriókban kizárólag a tracheában (45. ábra C, F) detektálható a dDAAM jel. A kinagyított képeken jól látszik, hogy míg a vad típusú embriók trachea ágaiban a dDAAM egységes szubkortikális mintát mutat (45. ábra A, D), addig a $d D A A M^{E x 68}$; TR embriókban a dDAAM gyakran pöttyökben aggregálódik (45. ábra $\mathrm{C}, \mathrm{F}$ ) valószínűleg a magasabb fehérje szint miatt. Összességében a dDAAM-R1 és dDAAM-R4 ellenanyag egyaránt felismeri az endogén és az aggregált dDAAM fehérjét is. Az aggregátumokban felhalmozódó dDAAM valószínüleg inaktív, mert a trachea specifikus FL-DAAM túltermelésnek nincs trachea fenotípusa ellentétben a konstitutívan aktív C-DAAM formával [228], ezért nem valószínú, hogy bármelyik ellenanyag is csak az aktív vagy az inaktív fehérjét ismerné fel.
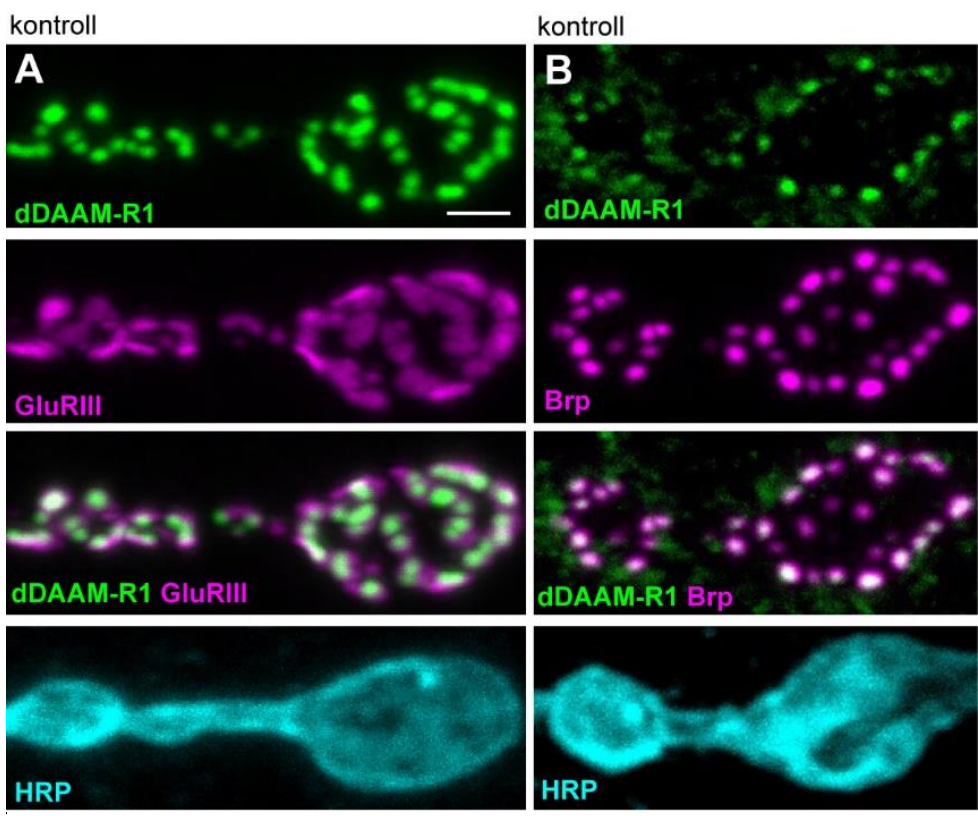

46. ábra A dDAAM nagyon erös kolokalizációt mutat a preszinaptikus Brp-vel. A kontroll $\left(w^{1118}\right)$ NMJ terminálisokat antidDAAM-R1 (zöld), anti-GluRIII (magenta) és anti-Brp (magenta) immunfestésekkel vizsgáltuk a 4-es izomnál. A dDAAM pöttyszerü lokalizációja részlegesen átfed a posztszinaptikus

GluRIII klasztereivel, míg a Brp esetében majdnem teljes az átfedés. A skála mértéke: $2 \mu \mathrm{m}(\mathrm{A}, \mathrm{B})$.

A dDAAM-R1 és R4 ellenanyag tesztelése után megvizsgáltuk, hogy a dDAAM-R1 pontszerü klaszterei a preszinaptikus aktív zónákkal vagy a posztszinaptikus GluR klaszterekkel fednek át. Ennek eldöntésére immunfestéseket végeztünk, amelyek alapján a dDAAM egyértelmüen preszinaptikus lokalizációt mutat, ahol szinte teljesen átfed az aktív zóna magi komponensével, a Brp-vel. Nagy felbontású STED mikroszkópiát alkalmazva az anti-Brp $\mathrm{N}$ term ellenanyag mintázata felülnézetből egy pontot rajzol ki, míg az anti-Brp C term 
(nc82) immunfestés szintén felülnézetből egy gyürü alakú struktúrát vesz fel a Brp N-term körül (19. ábra A) [184]. Kíváncsiak voltunk vajon a dDAAM a Brp N- vagy C-terminális részénél található. A jobb képminőség és felbontás érdekében két csatornás STED mikroszkópiát alkalmaztunk, amellyel $50 \mathrm{~nm}$-es laterális felbontást értünk el. A felülnézeti STED képeken a dDAAM jel az anti-Brp C-term ellenanyaghoz hasonlóan gyürü alakú struktúrát rajzol ki, amely nagyrészt átfed a Brp C-term jellel (47. ábra A). A maximum jelintenzitások távolság becslése alapján a két jel nagyjából 20 nm-re helyezkedik el egymástól (47. ábra B), a dDAAM jel legnagyobb részt a Brp gyürü belső pereménél található. Tehát a dDAAM a Brp azon fehérjerészéhez lokalizálódik, amely a szinaptikus vezikulák toborzásáért felelős.

\section{kontroll}

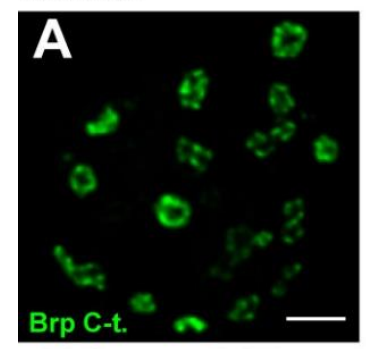

oldal

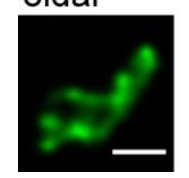

felül

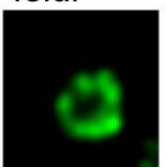

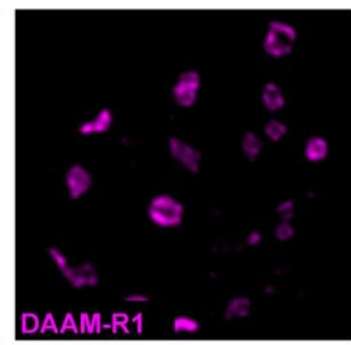
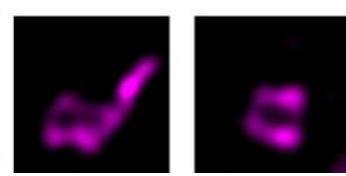
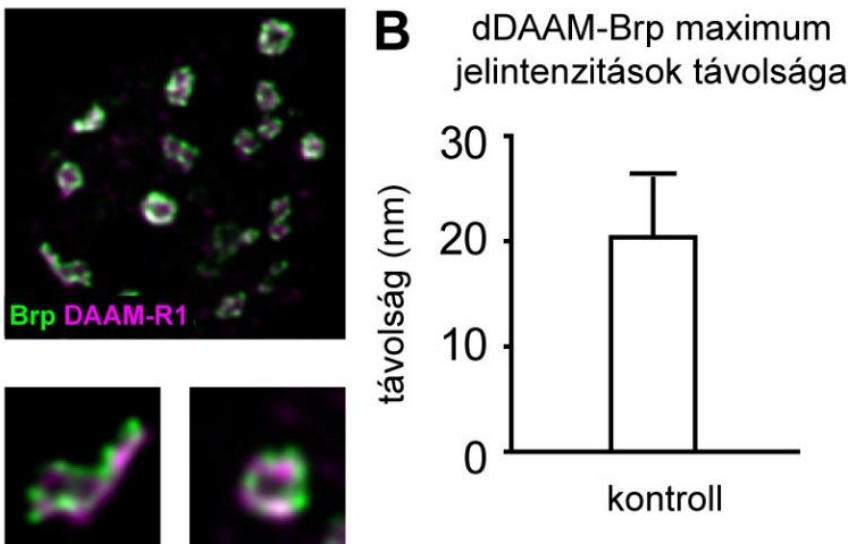

47. ábra A dDAAM preszinaptikus lokalizációjának vizsgálata STED mikroszkópiával. (A) A kontroll $\left(w^{1118}\right)$ NMJ festések alapján a dDAAM preszinaptikus pöttyszerű felhalmozódása az aktív zóna komplex disztális végéhez nagyon közel található. A fehérjék lokalizációját anti-Brp C-term.(zöld) és anti-dDAAM-R1 (magenta) ellenanyagokkal vizsgáltuk. (B) A dDAAM-Brp maximum jelintenzitásainak változása a szórás feltüntetésével ( $\mathrm{n} \geq 20)$. A skála mértéke: $750 \mathrm{~nm}(\mathrm{~A}), 250 \mathrm{~nm}$ nagy felbontású oldal és felülnézet (A).

Az aktív zóna összeszerelődésének első lépései közé tartozik az olyan központi vázelemek megjelenése, mint pl. a Brp $[\underline{182}, \underline{184}, \underline{185]}$. A Brp jelenléte nagyon fontos az aktív zóna képződésben, mert a fehérje hiányában nem jönnek létre funkcionális aktív zónák [182]. Kíváncsiak voltunk arra, hogy preszinaptikus aktív zóna komplexek hiányában létrejönnek-e dDAAM klaszterek, és ha nem, akkor mi történik a fehérjével. Létrehoztunk transzheterozigóta brp null mutáns állatokat, amelyekben nem meglepő módon eltüntek a preszinaptikus dDAAM klaszterek (48. ábra). 

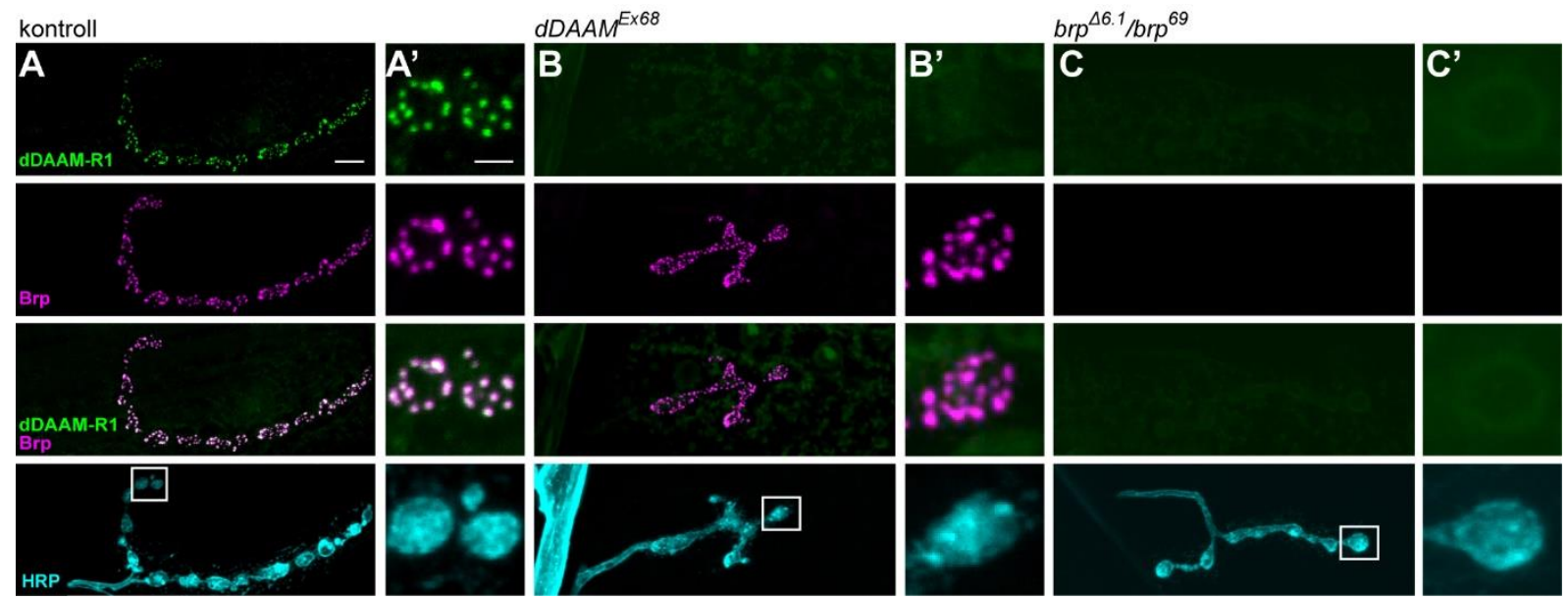

48. ábra A dDAAM fehérje aktív zóna közeli lokalizációja Brp függő. A kontroll ( $\left.\mathrm{A}, \mathrm{A}^{\prime}\right), d D A A M^{E x 68}$ (B, B') és brp null $\left(b r p^{46.1} / b r p^{69}\right)$ (C, C') NMJ terminálisokat anti-dDAAM-R1 (zöld), anti-Brp (magenta) és anti-HRP (cián) immunfestésekkel vizsgáltuk. Ellentétben a vad típusú kontrollal a dDAAM és brp null mutáns NMJ-kben a dDAAM preszinaptikus pöttyszerü felhalmozódása szinte teljesen eltünik. A fehér négyzetek az A, B és C paneleken a nagy felbontású képek (A', B', C') helyeit jelzik. A skála mértéke: $5 \mu \mathrm{m}$ (A, B, C), $2 \mu \mathrm{m}$ (A', B', C').

Western blot kísérletek alapján elmondható, hogy a Brp hiánya valószínűleg nem befolyásolja a dDAAM fehérje stabilitását, mert a vad és a $b r p^{\text {null }}$ mintákban a dDAAM fehérje szintje közel azonos (49. ábra A). Ezenkívül a brp null mutáns NMJ végződésekben az antidDAAM-R4 kortikális mintája a vad típushoz hasonló (49. ábra B, C). Következtetésképpen a dDAAM klaszterek létrejöttéhez Brp függő aktív zóna képződésre van szükség, de az aktív zóna komplex hiánya nem befolyásolja a dDAAM fehérje stabilitását.
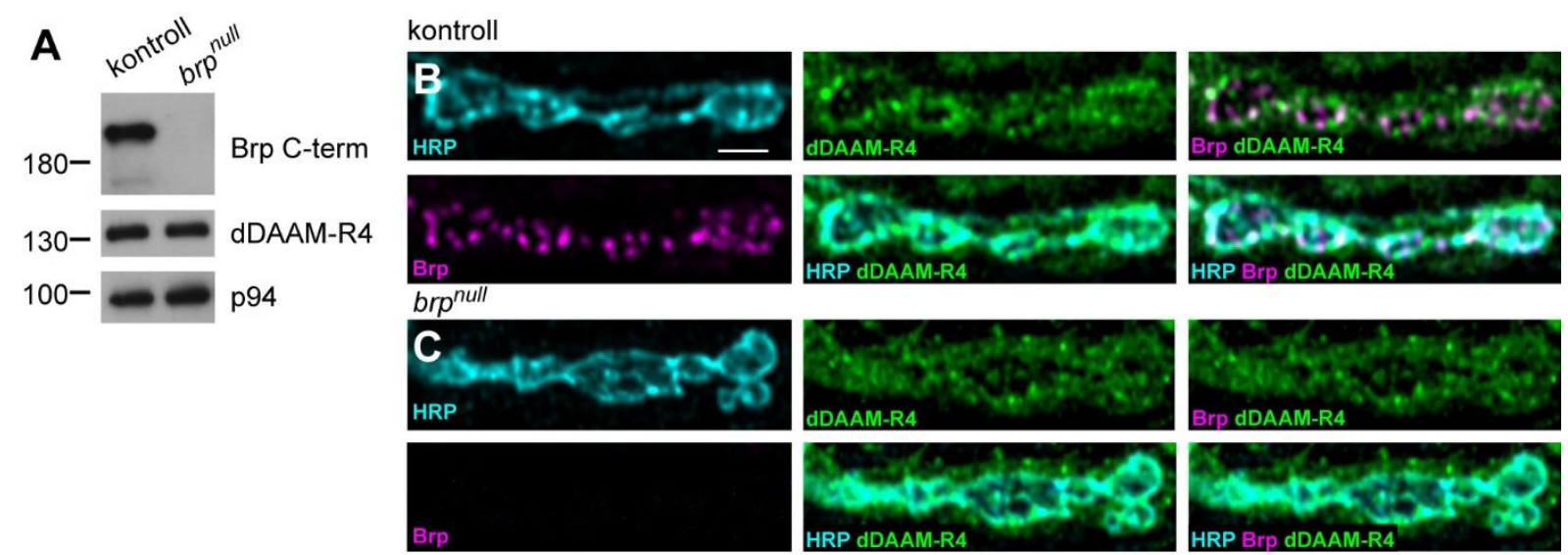

49. ábra A Brp hiánya nem befolyásolja a dDAAM fehérje stabilitását. (A) A Western blot kísérlet alapján a brp null KIR-ben a dDAAM kifejeződési szintje közel azonos a vad típusú kontrolléval $\left(w^{1118}\right)$. (B, C) A kontroll és a brp mutáns NMJ végződéseket anti-Brp (magenta), anti-dDAAM-R4 (zöld) és anti-HRP (cián) immunfestésekkel vizsgáltuk. A Brp fehérje hiányában (C) a kortikális dDAAM felhalmozódás a vad típushoz (B) nagyon hasonló, amely nagyrészt átfed a preszinaptikus membrán markerral. A skála mértéke: $3 \mu \mathrm{m}$ (B, C). 
A következőkben megvizsgáltuk, hogy a dDAAM hiánya okoz-e bármilyen változást az aktív zóna ultrastruktúrájában. Először STED mikroszkóppal vizsgáltuk a vad és a $d D A A M^{E x 68}$ aktív zóna szerveződést anti-Brp C- és N-term kettős immunfestéssel. A dDAAM null mutánsokban a Brp mintázat mindkét ellenanyaggal a vad típushoz hasonlónak látszott, azonban a Brp C term által kirajzolt gyürü átmérője kis mértékben megnőtt a mutánsokban a vad típushoz képest (50. ábra A, B, E). Az aktív zóna vázát felépítő elektrodenz fehérjekomplex elektronmikroszkóppal kiválóan vizsgálható, mert egy jellegzetes T alakú struktúrát vesz fel.
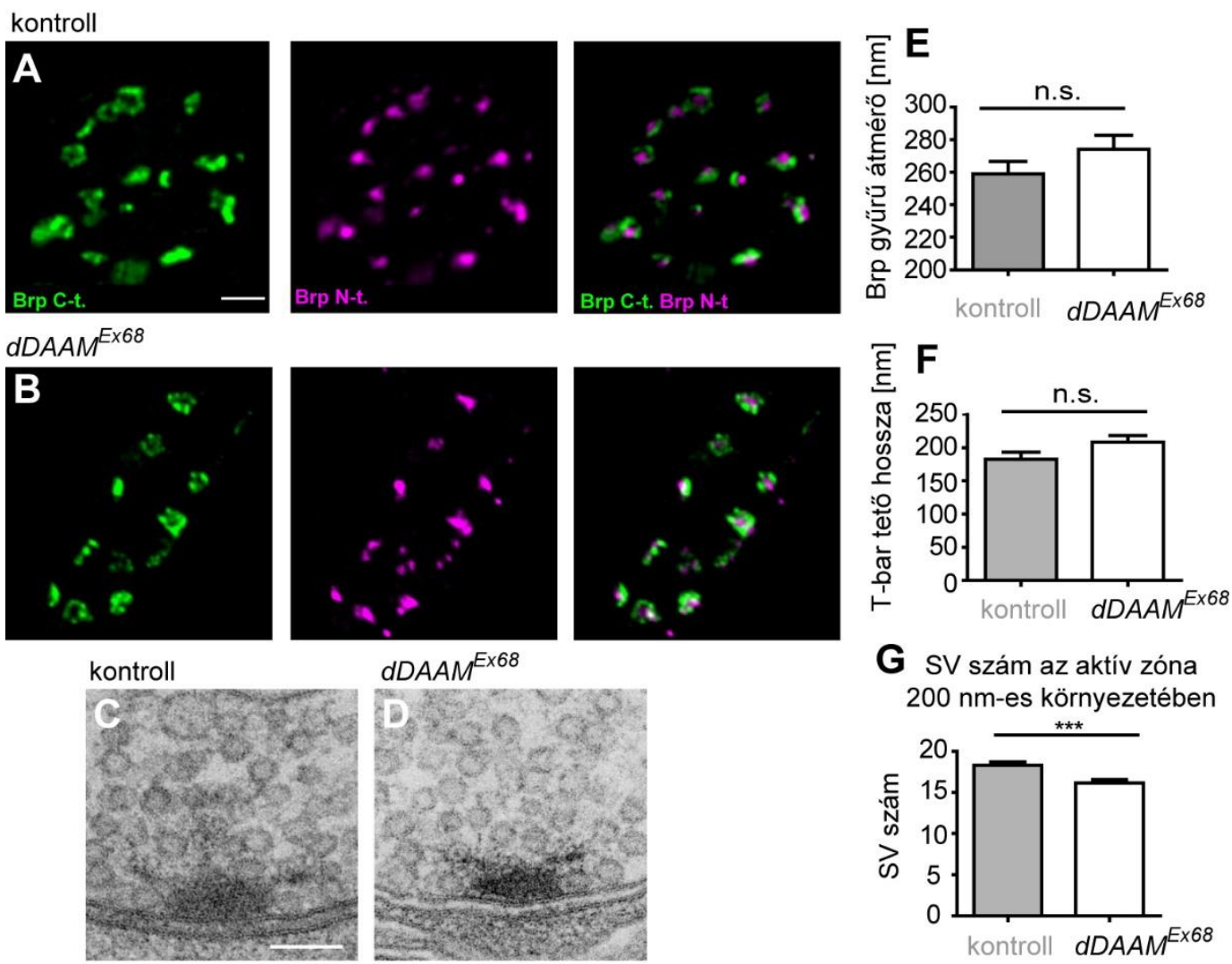

dDAAM $M^{E \times 68}$

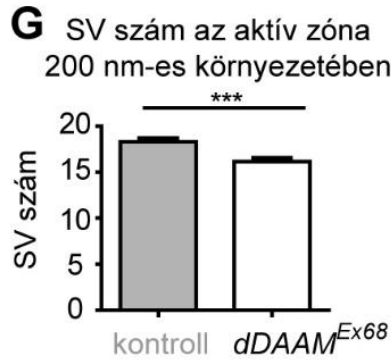

50. ábra A dDAAM hiánya befolyásolja az aktív zóna komplex ultrstruktúrális felépítését. $(\mathrm{A}, \mathrm{B})$ Az aktív zóna morfológiájának vizsgálata STED mikroszkópos képeken kontroll $\left(w^{1118}\right)$ (A) és $d D A A M^{E x 68}(\mathrm{~B})$ mutáns NMJ-ben anti-Brp N (magenta) és C term (zöld) ellenanyagok használatával. A STED analízis alapján a Brp gyürü átmérôjének enyhe nem szignifikáns (n.s.) mértékü emelkedése figyelhető meg a $d D A A M$ mutánsokban (E). (C, D, F) Az aktív zóna elektronmikroszkóppal történő vizsgálata alapján a $d D A A M$ mutánsokban a T-bar tető enyhe nem szignifikáns (n.s.) mértékü kiszélesedése (F) valamint az aktív zóna membránjának 200 nm-es környzetében az SV szám szignifikáns mértékű kismértékủ csökkenése (G) figyelhető meg. (E-G) A Brp gyürü átmérőjének, a Tbar tető hosszának és az SV szám változásának vizsgálata konroll és $d D A A M$ mutáns állatokban $(\mathrm{n} \geq 70)$. A skála mértéke: $750 \mathrm{~nm}(\mathrm{~A}, \mathrm{~B}), 100 \mathrm{~nm}(\mathrm{C}, \mathrm{D})$. Az oszlopok átlagértékeket ábrázolnak a szórások feltüntetésével. $* * * \mathrm{p}<0.001$ 
Az előző kísérletekhez hasonlóan vad és $D D A A M^{E x 68}$ mutánsokban vizsgáltuk meg az aktív zóna szerveződést. A $d D A A M$ mutánsokban drasztikus változást nem láttunk az aktív zóna komplex T alakú struktúrájában (T-bar), viszont a T struktúra felső része kissé megnyúlt a $d D A A M^{E x 68}$ mutánsban a vadhoz képest (50. ábra C, D, F). Az elektronmikroszkópos vizsgálatok azt is lehetővé tették, hogy megvizsgáljuk a szinaptikus vezikulák (SV) számát az aktív zóna környezetében. Megfigyelhető volt, hogy a $d D A A M$ mutáns aktív zónák 200 nm-es környezetében az SV sürűség egy kismértékü, de szignifikáns csökkenést mutatott (50. ábra C, D, G). Az ultrastruktúrális vizsgálatok alapján a dDAAM nem létfontosságú az aktív zóna komplex kialakításában és az SV-k összegyüjtésében, de képes lehet finoman hangolni ezeket a folyamatokat. Illetve az is elképzelhető, hogy azért látunk gyenge fenotípusokat az aktív zónák tekintetében, mert a dDAAM aktív zónához köthető funkciója redundáns lehet esetleg más forminokéval.
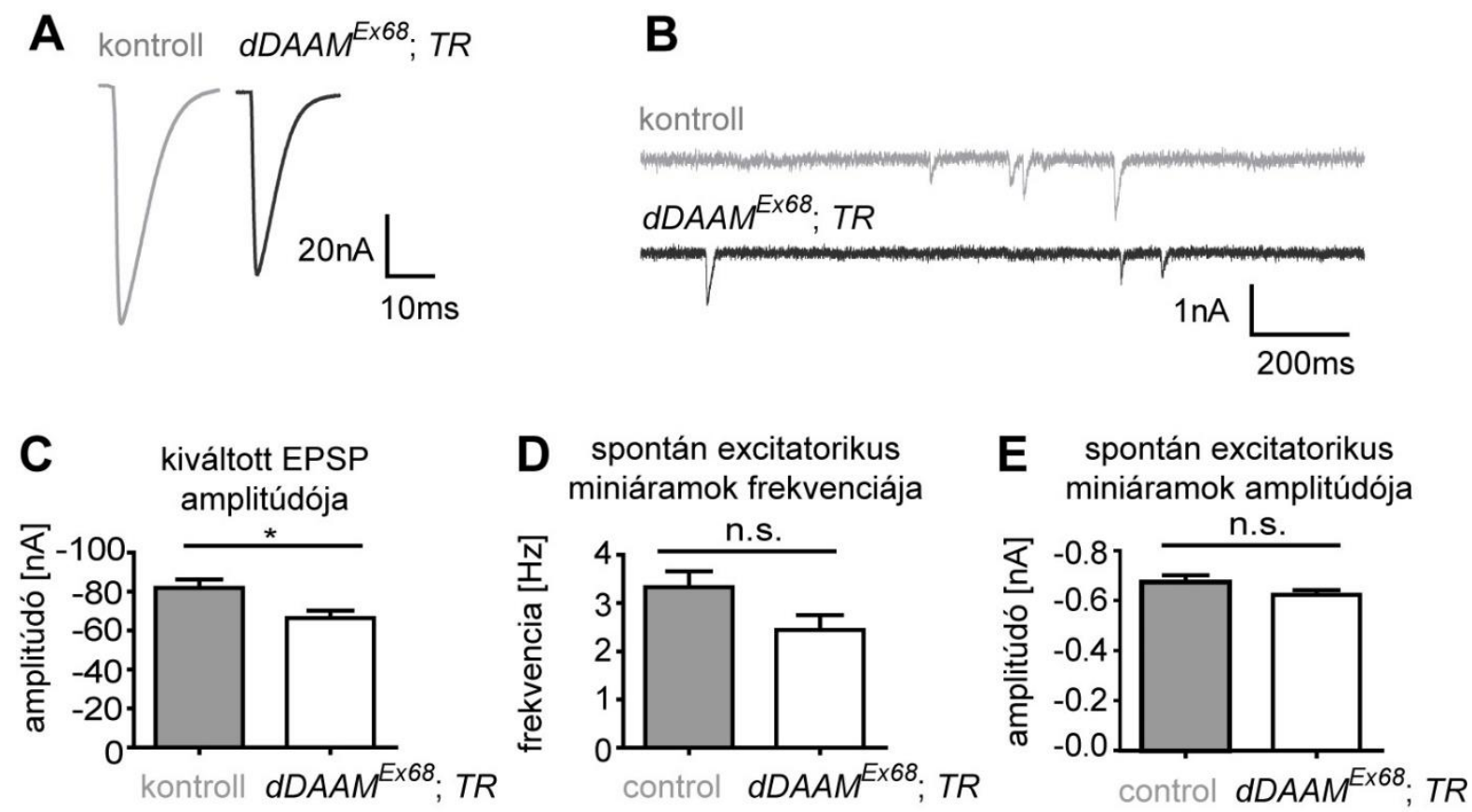

51. ábra A dDAAM befolyásolja a szinaptikus transzmisszió hatékonyságát. (A-E) A 6/7 izom NMJ terminálisainak elektrofiziológiai vizsgálata (TEVC, two-electrode voltage clamp) kontroll $\left(w^{1118}\right)$ és $d D A A M^{E x 68}$; TR állatokban. (A, C) A dDAAM hiányában kiváltott EPSP (excitatorikus posztszinaptikus potenciál) amplitúdója körülbelül 19\%-kal kisebb a vad típusú kontrollhoz képest, (B, D, E) ettől eltérően a spontán excitatorikus miniáramok karakterisztikájában nem láttunk szignifikáns (n.s.) különbséget. Az oszlopok átlagértékeket ábrázolnak a szórások feltüntetésével. * $\mathrm{p}<0.05$, *** $\mathrm{p}<0.001$. $\mathrm{n} \geq 10$ (C-E).

Végezetül elektrofiziológiai módszerekkel megvizsgáltuk azt, hogy a dDAAM hiánya befolyásolja-e a szinaptikus transzmisszió hatékonyságát. TEVC (two-electrode voltage clamp) 
kísérleteket végeztünk vad típusú és mutáns $d D A A M^{E x 68} ; T R$ állatokon. Habár a spontán szinaptikus áramok karakterisztikájában nem láttunk változást (51. ábra $\mathrm{B}, \mathrm{D}, \mathrm{E}$ ), a kiváltott akciós potenciál (AP) amplitúdója 19\%-kal kisebb volt a $d D A A M^{E x 68}$; TR állatokban a vad típushoz képest (51. ábra A, C). A $d D A A M$ mutánsokban megfigyelhető csökkent SV szám az aktív zóna környeztében valószínüleg összefüggésben van a csökkent kiváltott AP-val, de hogy pontosan milyen mechanizmusokat érint, az további vizsgálatokat igényel. Összességében elmondható, hogy a dDAAM tagja az aktív zóna fehérjekomplexnek, amelynek hiánya befolyásolja a szinaptikus felszabadulás mértékét. 


\section{EREDMÉNYEK MEGVITATÁSA}

Az idegrendszer fejlődése során milliónyi szinaptikus kapcsolat jön létre és szünik meg, amely nélkülözhetetlen feltétele olyan komplex idegi folyamatoknak, mint pl. a tanulás, a memóriaképzés és az érzékelés. Az utóbbi évtizedek neurobiológiai kutatásai fényt derítettek arra, hogy a szinaptikus fejlődés, funkció és struktúra fenntartásának bonyolult folyamataiban a sejtváznak a dinamikus átrendeződése is fontos szerepet játszik. Az aktin és a mikrotubulus sejtváz egyaránt részt vesz a szinaptikus stabilizálódás, a bouton képződés és a szinaptikus vezikulák felszabadulásának a mechanizmusaiban. Az aktin és a mikrotubulus organizáció összetett jelátviteli útvonalak szabályozásán keresztül valósul meg. A tudásunk folyamatosan bővül új upstream sejtvázszabályozó elemek megismerésével, viszont még keveset tudunk arról, hogy a sejtváz effektor fehérjéi miként kötődnek az aktin/mikrotubulus sejtvázhoz és hogyan szabályozzák azokat. A sejtváz effektor fehérjéinek vizsgálatával jobban megérthetjük a sejtváz-átrendeződések dinamikus folyamatait. A figyelmünk fókuszába a formin fehérjecsaládba tartozó dDAAM került, amely az aktin összeszerelő aktivitása révén szerepet játszik az axon növekedés és navigáció folyamataiban [231, 232]. Legutóbbi in vitro eredményeink alapján a dDAAM az aktin mellett képes a mikrotubulusokhoz is kötődni, amelynek in vivo szerepe lehet a növekedési kúpban az aktin/mikrotubulus kölcsönhatásokban [129]. A dolgozatban szereplő kísérletek arra összpontosultak, hogy megvizsgáljuk a dDAAM sejtváz effektor fehérje miként befolyásolja a sejtvázszerveződést a szinaptikus fejlődés és funkció folyamataiban.

Először megállapítottuk, hogy a dDAAM a szinapszisképződés egyik korai szereplője, már az embrionális fejlődés során szükség van a fehérje kifejeződésére. A dDAAM fehérje hiányában az embrionális ISNb motoraxon növekedési és navigálási hibát egyaránt mutat az NMJ terminálisoknál. A vizsgálatainkat kiterjesztve a lárvális NMJ végződések vizsgálatára megállapítható, hogy a dDAAM pre- és posztszinaptikusan is kifejeződik. A $d D A A M$ mutáns NMJ terminális lárvában abnormális fejlődést mutat bouton szám és NMJ morfológia tekintetében. A dDAAM hiányos motoraxon végződésekben drasztikus bouton szám csökkenés figyelhető meg, illetve a boutonokat összekötő inter-boutonikus régió kiszélesedik bouton 
fúziós fenotípust eredményezve. További funkcióvesztéses vizsgálatokból kiderült, hogy a látott NMJ fenotípusokat elsősorban a dDAAM preszinaptikus hiánya okozza.

Mivel az eredmények a dDAAM preszinaptikus szerepére utaltak, kíváncsiak voltunk arra, hogy a dDAAM hiánya befolyásolja-e a preszinaptikus mikrotubulus és/vagy aktin szerveződést a motoraxon végződésben. Mivel a Futsch, mint preszinaptikus mikrotubulus marker a legígéretesebb dDAAM kölcsönható partnernek tünt, ezért a mikrotubulus rendszert vizsgáltuk először a $d D A A M$ mutánsokban. A vad típusú NMJ-ben látható rendezett központi mikrotubulus köteg struktúrája dDAAM hiányában fragmentált és dezorganizált szerveződést mutat. A forminokat eddig főként aktin polimerizációs faktorként ismertük, de az utóbbi időben egyre több munka foglalkozik a mikrotubuluskötő funkciójukkal is. A csoportunk eredményei alapján a dDAAM képes in vitro kötődni a mikrotubulusokhoz valamint a dDAAM fehérje hiánya befolyásolja a mikrotubulusok morfológiáját és azok dinamikájának néhány aspektusát primer idegsejtekben [129]. Egy másik érdekes megfigyelésünk, hogy a dDAAM in vitro képes keresztkötni az aktin és mikrotubulus filamentumokat, amely nagyon fontos lehet az axon növekedés irányának a meghatározásában. A fentiek miatt úgy gondoltuk, érdekes lenne megvizsgálni, hogy vajon a dDAAM aktin és/vagy mikrotubuluskötő funkciója fontos-e a bouton képződésben. A menekítési kísérletek alapján a dDAAM aktin összeszerelő aktivitása nem szükséges a bouton képződés során. Ezután felmerült bennünk a kérdés, hogy a $d D A A M$ mutáns NMJ-ben vajon a preszinaptikus aktin organizáció érintett-e. A $d D A A M$ mutáns preszinaptikus motoraxon végződésben az aktin szerveződés a vad típushoz nagyon hasonló volt, így ez az eredmény megerősített bennünket abban, hogy a dDAAM aktin összeszerelő aktivitása nem szükséges a bouton képződés során.

A funkcióvesztéses kísérletek alapján a dDAAM preszinaptikus jelenléte képes elősegíteni a bouton képződést. Azért, hogy megerősítsük ezt a megfigyelésünket funkciónyeréses vizsgálatokat végeztünk. A dDAAM a DRF forminok tagjaként rendelkezik azzal a tulajdonsággal, hogy a fehérje aktivátor hiányában inaktív konformációt vesz fel. A fehérje N- és C-terminális része közötti intramolekuláris interakció gátolja a katalitikus FH1FH2 domének aktivitását [42, 44]. A fehérje N-terminális régiójának eltávolításával létrehoztunk egy olyan csonkolt dDAAM formát (C-DAAM), amely aktív formaként viselkedett. A C-DAAM preszinaptikus túltermelése jelentős mértékben megemelte a bouton 
számot, ami megerősíti azt az elképzelésünket, hogy a dDAAM a bouton képződés pozitív szabályozó faktora.

Egy nagyjából 10 évvel ezelőtti közleményben bemutatták, hogy egy másik DRF formin a Dia fontos szerepet játszik az NMJ fejlődésben [196]. A Dia a pre- és posztszinaptikus oldalon egyaránt kifejeződik, de a funkcionális vizsgálatok a Dia preszinaptikus szerepére utaltak. A Dia hiánya egyértelműen befolyásolja az aktin és mikrotubulus szerveződést, ami bouton szám csökkenést okoz. Bemutatták továbbá, hogy a Dia valószínüleg a Dlar és a Trio által szabályozott jelátviteli útvonal effektor fehérjéje [196]. A dDAAM hasonlóan a Dia-hoz mindkét szinaptikus oldalon jelen van, aminek hiánya szintén csökkent bouton számot eredményez. Ezenkívül közös jellemzője még a két fehérjének, hogy a preszinaptikus hiányuk okozza a bouton szám csökkenést. Fontos különbség viszont, hogy kizárólag a $d D A A M$ mutánsokban figyelhető meg a kiszélesedő inter-bouton régió a dia mutánsokban nem. Ezenkívül a sejtvázra gyakorolt hatásukban is lényeges különbségek vannak. A Dia-tól eltérően a dDAAM hiányának nincs hatása az aktin szerveződésre, amit megerősít az, hogy az aktinkötésre képtelen dDAAM forma képes menekíteni az NMJ fejlődési hibákat. A mikrotubulusok szerveződésére mindkét forminnak hatása van, de míg a dDAAM hiánya a teljes mikrotubulus köteg instabilitását okozza, addig a Dia esetében „csak” a dinamikus pionír mikrotubulusok érintettek. Végül a két formin úgy tünik két különböző jelátviteli útvonal szabályozása alatt áll. A dDAAM a genetikai interakciós tesztek és az NMJ fenotípusok alapján egyértelmüen a $\mathrm{Wg} / \mathrm{Ank} 2$ jelátviteli úthoz tartozik, ezzel szemben a Dia a Dlar és a Trio fehérjék szabályozása alatt áll. Érdekes módon más idegrendszeri struktúrákra is jellemző, hogy ez a két formin egymástól függetlenül müködik. A gombatestben a dDAAM a nyúlványnövekedés pozitív regulátora a Wnt/PCP rendszeren keresztül [231], míg a Dia egy eddig ismeretlen jelátviteli útvonalban inkább a nyúlvány növekedés leállításáért felelős. Összességében a két formin típusú fehérje különböző módon szabályozódik és jelentősen eltér a preszinaptikus mikrotubulus szerveződésre gyakorolt hatásuk. A Dia elsősorban a mikrotubulus dinamikát modulálja a pionír mikrotubulusokon keresztül [196], míg a dDAAM a központi mikrotubulus köteg stabilizációjáért felelős a preszinaptikus végződésben.

A mikrotubulus rendszer megfelelő szabályozása rendkívül fontos a szinaptikus bouton képződés mechanizmusaiban. Számos jelátviteli utat hoztak összefüggésbe a preszinaptikus 
mikrotubulusokkal, ezek egyik legfontosabb képviselője a Wg/Wnt jelátviteli útvonal [219, 220]. A kanonikus Wnt szignalizációban a Wg kötődése a Fz receptorhoz és ko-receptorához az LRP5/6-hoz (Drosophila Arrow) aktiválja a Dishevelled (Dsh) fehérjét, ami gátolja a destrukciós komplexet. Wnt hiányában a destrukciós komplex egyik tagja a Gsk3- $\beta$ (Drosophila Shaggy vagy Sgg) foszforilálja a $\beta$-katenint, ami annak lebontásához vezet. Ezzel szemben a Wnt molekula bekötődésével a Dsh aktiválódik, ami a destrukciós komplex szétesését eredményezi. A destrukciós komplex hiányában a $\beta$-katenin feldúsul, és a sejtmagba kerül, ahol Wnt target géneket aktivál [145]. Jelenlegi tudásunk szerint a Drosophila NMJ preszinaptikus oldalán a divergens kanonikus Wnt szignalizáció müködik, ami eltérően a klasszikus kanonikus útvonaltól $\beta$-katenin független és nem befolyásolja a Wnt célgének transzkripcióját. Wnt hiányában az Sgg foszforilálja a mikrotubuluskötő Futsch fehérjét, ami olyan változást okoz a mikrotubulus szerveződésben, ami csökkenti a szinaptikus bouton képződést. Ezzel szemben Wnt jelenlétében egy eddig ismeretlen receptor és az Arrow koreceptor komplexe aktiválja a Dsh fehérjét gátolva az Sgg függő Futsch foszforilációt, ami a mikrotubulusok stabilizálódásához vezet, ezzel elősegítve az új boutonok létrejöttét [르, 220]. Fontos megemlíteni, hogy a dDAAM emlős homológját az mDAAM1 fehérjét, eredetileg egy Dsh asszociált Wnt jelátviteli komponensként azonosították [136]. Kezdetben az mDAAM1 fehérjét a nem kanonikus Wnt/PCP rendszerhez kötötték [136], majd később a kanonikus Wnt útvonallal is kapcsolatba hozták. A mi csoportunk is a Drosophila DAAM-ot elöször a nem kanonikus Wnt/PCP rendszerrel hozta összefüggésbe az axon növekedés során [231]. A legújabb, a dolgozatban szereplő eredményeink pedig azt sugallják, hogy a dDAAM a divergens kanonikus Wnt jelátviteli út egyik komponenseként befolyásolja a szinaptikus fejlődés folyamatait [233]. A fentiek alapján a dDAAM, hasonlóan a Dishevelled fehérjéhez, a kanonikus és nem kanonikus Wnt jelátviteli útvonal tagjaként egyaránt jellemezhető. A kísérleteinkben bebizonyítottuk, hogy a wg és a $d D A A M$ domináns genetikai kölcsönhatást mutat az NMJ fejlődésben. A Wg és a dDAAM kapcsolatát erősíti, hogy a $d D A A M$ funkcióvesztéses fenotípusa számos elemében hasonlít a wg fenotípushoz. Mindkét mutáns NMJ végződésben megfigyelhető a boutonok számának a csökkenése és a mikrotubulus rendszer instabilitása. Az NMJ morfológiát érintő eltérések mellett a dDAAM és a Wg hiánya egyaránt hatással van az aktív zóna komplex felépítésére. Az Ank2 a Wg jelátviteli út 
szabályozása által szintén befolyásolja a mikrotubulus dinamikát és szerveződést. Az Ank2 egy óriási adaptor molekula, amely összekapcsolja a kortikális Spektrin/aktin hálózatot a központi mikrotubulus köteggel. Az Ank2 null mutáció a terminális boutonokban gyakran a mikrotubulus szerveződés teljes hiányát és a központi mikrotubulus köteg jelentős megvastagodását okozza [216, 217]. Habár a bouton fúziós fenotípus az Ank2 és Wg jelátviteli útvonal mutánsaira (wg, $d s h, a r r)$ egyaránt jellemzö [219, 220] (kivéve futsch, sgg), fontos különbség, hogy csak az Ank2 hiányában jön létre mikrotubulus aggregáció a preszinaptikus végződésben. Tehát az Ank2 valószínüleg más jelátviteli útvonallal is kapcsolatban lehet. Ettől függetlenül mindenképpen elmondható, hogy az Ank2 és a Futsch a Wg/Arr/Dsh/Sgg szignalizációs egységtöl downstream helyezkedik el [223]. A kérdés az, hogy vajon a dDAAM ebben a hierarchia viszonyban hol helyezkedik el. A genetikai episztázis kísérletekben a dDAAM hiánya egyértelműen szuppresszálta az Ank2 mutáns aggregált mikrotubulus fenotípusát. A Futsch-hoz hasonlóan a dDAAM szükséges ahhoz, hogy az Ank2 mutánsokban kialakuljon a preszinaptikus mikrotubulus akkumuláció. Ebben a kísérleti elrendezésben a dDAAM az Ank2től downstream helyezkedik el, mint mikrotubulus stabilizáló faktor. A dDAAM; Ank2 kettős mutáns fenotípusa viszont nem teljesen azonos a $d D A A M$ mutáns NMJ fenotípusával, ami arra utal, hogy nem egy egyszerủ alá-fölé rendeltségi viszony van a két fehérje között. Ettől eltérően a $d D A A M / f u t s c h$ kettős mutáns állatokban csökkent bouton szám, bouton fúzió valamint szakadozott mikrotubulus kötegek észlelhetőek hasonlóan a $d D A A M$ egyes mutánshoz. Az eddigi eredmények alapján valószínüleg az Ank2, Futsch és dDAAM, mint sejtváz effektor fehérjék egy általunk eddig nem ismert komplex jelátviteli struktúrában szabályozzák a mikrotubulus dinamikát és szerveződést.

Az információ akciós potenciál formájában érkezik a preszinaptikus idegvégződésre és adódik át jelmolekulák (glutamát) segítségével a posztszinaptikus félre. A preszinaptikus félen a glutamát apró vezikulákba csomagolódik, amelyek felszabadulása az aktív zónáknál történik. Lokalizációs vizsgálatok alapján a dDAAM fehérje a preszinaptikus oldalon membránhoz közeli kortikális és aktív zóna felhalmozódást egyaránt mutat. A nagy felbontású STED mikroszkópia lehetővé tette, hogy megállapítsuk, hogy a dDAAM felhalmozódás egy gyürüszerü struktúrát rajzol ki, ami nagyrészt átfed a Brp C-terminális fehérjerész mintázatával, ami az aktív zóna fehérjekomplex disztális vége [184]. A lokalizációs vizsgálatok mellett 
funkcionális bizonyítékokat is találtunk arra vonatkozólag, hogy a dDAAM befolyásolhatja az aktív zóna kialakulását, illetve annak müködését. Megvizsgálva az aktív zónák ultrastruktúrális szerkezetét a $d D A A M$ mutáns állatokban az aktív zóna átmérője kis mértékben megnőtt. Továbbá a kiváltott AP amplitúdója kisebb a $d D A A M$ mutánsban, amit megerősít az, hogy az aktív zóna környezetében a szinaptikus vezikulák számának a csökkenését tapasztalhatjuk. Érdekes módon nemrégiben kiderült, hogy a Futsch szintén modulálja a szinaptikus transzmissziót [234]. A dDAAM-hoz hasonlóan a Futsch az aktív zóna komplex környezetében is megtalálható valamint a futsch mutánsban a szinaptikus felszabadulás hatékonysága csökken. Mivel mindkét fehérje a mikrotubulusok stabilizációjáért és organizációjáért lehet felelős, ezért elképzelhető, hogy részt vesznek az aktív zóna és a központi mikrotubulus köteg közti interakció kialakításában.

A mikrotubulus rendszer mellett jól ismert tény, hogy az F-aktin szerveződés szerepet játszik a szinaptikus felszabadulásban és tagja az aktív zóna fehérjekomplexnek [요, $\underline{192}, \underline{201}$, 202]. Habár az aktin összeszerelődésének a szabályozása nagyrészt ismeretlen, azt lehet tudni, hogy az aktív zóna komponens Piccolo egy fontos szabályozója gerincesekben az aktin filamentumoknak, azáltal, hogy számos aktinkötő fehérjével kölcsönhatásba kerül és platformot biztosít a térbeli aktin filamentumok kialakulásának [204, 206]. Primer neuron kultúrákban kimutatták, hogy az aktivált DAAM1 a Piccolo-hoz kötődik, és ez az interakció térben irányítja az F-aktin összeszerelődést. A DAAM1 hiányos neuronokban a preszinaptikus F-aktin szerveződés jelentősen megváltozik [206]. A mi eredményeink alapján a dDAAM aktin összeszerelő aktivitására nincs szükség a szinaptikus bouton képződésben, ettől független nem tudjuk kizárni annak a lehetőségét, hogy a dDAAM rendelkezik aktinhoz köthető funkcióval az aktív zóna környezetében. Mivel a dDAAM elősegíti az aktin-mikrotubulus interakciót a növekedési kúpban [129], elképzelhető, hogy az aktív zóna disztális részén fontos lehet ez a funkció a szinaptikus vezikulák toborzásában. További kísérletek szükségesek, hogy jobban megértsük ezeket a folyamatokat. 


\section{ANYAGOK ÉS MÓDSZEREK}

\section{Felhasznált Drosophila törzsek}

Bloomingtoni Drosophila Törzsközpontból szerzett mutáns törzsek a katalógus számok feltüntetésével:

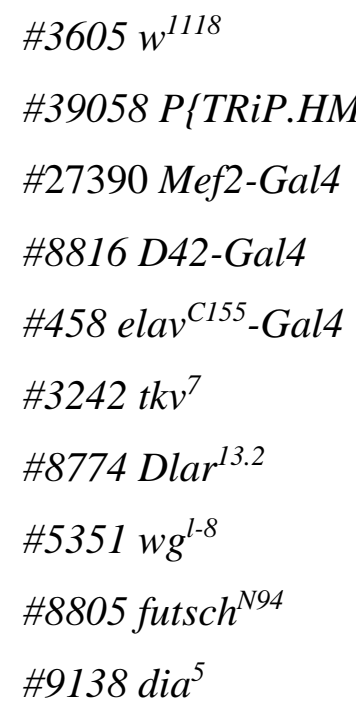

Korábbi közleményekben használt mutáns törzsek a hivatkozás vagy a forrás feltüntetésével:

dDAAM $M^{E x 68}$ [228]

btl-Gal4 (C. Samakovlis)

futsch $^{K 68}$ (M-L. Parmentier)

brp ${ }^{46.1}$ [185]

brp $^{69}$ [182]

Ank2 ${ }^{518}$ [217]

Ank2-XL ${ }^{4}$ [218]

A következő törzseket hoztuk létre:

$U A S-C D A A M^{3 X F l a g}$ : A C-DAAM-nak megfelelő szekvencia részletet elöször ENTRY vektorba klónoztuk, majd LR reakcióval pTWF-C-DAAM konstruktot hoztunk létre, amit random a genomba építettünk be. Az általunk használt transzgenikus törzs 2. kromoszómáján található a túltermelő konstrukt.

P\{UAS-FLDAAM \}attPVIE-260B, P\{UAS-FLDAAM $\left.{ }^{732}\right\} a t t P V I E-260 B, \quad P\left\{U A S-F L D A A M^{876-}\right.$ ${ }^{881}$ jattPVIE-260B. A különböző FLDAAM szekvencia részleteket először ENTRY vektorba klónoztuk (primer lista), majd LR reakcióval pTWattB-FLDAAM, pTWattB- FLDAAM ${ }^{732}$ és 
pTWattB-FLDAAM ${ }^{876-881}$ konstruktokat hoztunk létre, amelyeket a 2. kromoszómán ugyanabba a genomikus pozícióba építettünk be (attP-VIE-260B).

P\{UAS-shRNS-dDAAMFH2\}attP2 (korábban dDAAM-RNSi 1): A 21 bázispár hosszúságú dDAAM szekvencia részletet (primer lista) pV20 vektorba klónoztuk, amit a 3. kromoszómán az attP2 dokkoló helyre építettünk be.

dDAAM ${ }^{3 x F l a g}$ : A Flag tagelt knock-in allélt gén konverziós technika segítségével hoztuk létre a korábban leírtaknak megfelelően [235].

futsch $^{C R 13 \text { és }}$ dDAAM ${ }^{E x 68}$, futsch ${ }^{C R 13}$ : A futsch mutáns törzseket CRISPR/Cas9 technika segítségével hoztuk létre egy korábbi közleménynek a módszertana alapján [236]. Röviden a kísérlet menete a következő: vad $\left(w^{1118}\right)$ és $d D A A M$ mutáns háttéren 300 bázispáros deléciót hoztunk létre a futsch első kódoló exonjában. A létrejövő deléció frameshiftet és ezáltal korai terminációt okoz a fehérje transzlációjában. Az immunfestés és a Western blot alapján a futsch ${ }^{C R 13}$ protein null allélnek tekinthető.

\section{Lárvafilé preparálása}

A lárvákat PBS-ben boncoltam, majd szobahőmérsékleten 20 percig fixáltam 4\%-os PBS-ben hígított paraformaldehiddel. A fixálás után a lárvafiléket 3×20 percig PBST-vel mostam, majd Eppendorf csőbe helyeztem, és PBS-BT-ben 2h-t szobahőn blokkoltam.

\section{Embriók preparálása}

Az embriókat a táptalajról desztillált vízzel lemosva nylon membránon fogtuk fel, majd következő lépésben 1 percig hipóba (Clorox) áztattuk őket, eltávolítva az embrió külső, korion burkát. A dekorionizált embriókat desztillált vízzel mostuk, majd a felesleges vizet leitatva róluk, $3 \mathrm{ml} \mathrm{N}$-heptánt tartalmazó szcintillációs üvegbe helyeztük át őket és $3 \mathrm{ml}$ PBS-sel hígított 4\%-os formaldehidet mértünk rá. A fixálás 20 percig tartott, ezután eltávolítottuk a formaldehides (alsó) fázist. Következő lépésként 1,5 tf $-20^{\circ} \mathrm{C}$-os metanolt mértünk az embriókra, és a két elkülönülő fázist $45 \mathrm{mp}$-ig folyamatosan összeráztuk. A rázás során az embriók kb. 80\%-nál felszakad az őket borító vitellin membrán, és a devitellinizált embriók az alsó (metanol) fázisba süllyednek. A devitellinizált embriókat Eppendorf csőbe tettük. Ezután az embriókra $1 \mathrm{ml}$ PBS : metanol (1:1) keveréket mértünk. 10 perc múlva a PBS : metanol-os oldatot eltávolítottuk, 15 perc múlva a PBS : metanol-os oldatot eltávolítottuk, és PBS-T-vel 
(PBS, 0,1\% Triton-X) 3-szor 10 percig mostuk az embriókat, majd PBS-BT-vel (PBS, 0,1\% Triton-X, 0,2\% BSA) 2 h-t blokkoltuk.

\section{Immunhisztokémia}

A blokkolt, devitellinizált embriókat, vagy a kiboncolt és lefixált lárvafiléket egy éjszakán keresztül (kb.18h) festettem $4^{\circ} \mathrm{C}$-on PBS-BT-vel megfelelő koncentrációra kihígított elsődleges antitesttel, majd 4-ször 20 percig mostam őket. Ezután megfelelő koncentrációra PBS-BT-vel kihígított fluoreszcens vagy biotinilált másodlagos ellenanyagot tettem rájuk, és 2-3 h-t inkubáltam. A következő elsődleges ellenanyagokat használtam: nyúl anti-HRP (Jackson) 1:200, kecske anti-HRP-Alexa-647 (Jackson) 1:600, egér anti-Dlg (DSHB, 4F3) 1:100, egér anti-Futsch (DSHB, 22C10) 1:200, nyúl anti-Futsch C-term 1:1000 [221], egér antiBrp C-term. (DSHB, nc82), nyúl anti-Brp N-term.[184] 1:1000, egér anti-acetilált-tubulin (Sigma, 6-11B-1) 1:1000, nyúl anti-dDAAM-R1 [228] 1:1000, nyúl anti-dDAAM-R4 [232] 1:500. Az elsődleges ellenanyag használatát követően a megfelelő Alexa-488,546 és 647 (Invitrogen) fluoreszcens festékkel konjugált másodlagos ellenanyagokat használtuk.

\section{Western blot}

A kísérletek során mintánként 10 adult vagy lárvális agyat lizáltunk $100 \mu 1$ lízis pufferben $(0,1 \%$ SDS; 0,2\% NaDoc; 0,05\% NP40; 150mM NaCl; 50mM Tris-HCl), majd 10 percig forraltuk őket. A forralás után a mintákat 10 percig 13.000 rpm-en lecentrifugáltuk, majd denaturáló SDS gélen megfuttattuk. Az elválasztott fehérjéket Millipore PVDF membránra blottoltuk. A blottolási lépést követően a membránokat 5\% sovány tejport tartalmazó TBST-ben blokkoltuk 3h-ig szobahőn, majd egy éjszakán át inkubáltuk őket a blokkolóban hígított megfelelő elsődleges ellenanyagokkal. Ezt követően a membránokat TBST-ben 3x20 percig mostuk, majd a megfelelő másodlagos ellenanyagokkal kiegészített 5\% sovány tejpor TBST-s oldatában 1 ht szobahőn inkubáltuk. Ezek után a membránokat 3x20 percig TBST-ben mostuk, majd Millipore Immobilon kemilumineszcens detekciós reagenssel előhívtuk. A következő elsődleges ellenanyagokat használtuk: nyúl anti-dDAAM-R4 [232] (1:500), egér anti-Flag (Sigma, M2, 1:500), egér anti-Futsch (DSHB, 22C10, 1:100) és nyúl anti-glycogen phosphorylase (1:20.000). Az elsődleges ellenanyag használatát követően a megfelelő antiHRP (Invitrogen) másodlagos ellenanyagot használtuk 1:10.000 hígításban. 


\section{Tömegspektrometriai vizsgálat}

Az anti-Flag affinitástisztítás után az eluált fehérjéket denaturáló gélelektroforézissel (SDSPAGE) futtattuk meg. A vad típusú és a dDAAM::Flag sávokat kivágtuk a gélből és ezeket 12 darabra vágtuk, amelyeket tripszinnel emésztettünk. A tripszines kezelés után létrejövő peptideket LC-MS/MS analízissel vizsgáltuk nanoAcquity UPLC Orbitrap-Elite mass spectrometer (Thermo Fisher Scientific) rendszer segítségével. A csapdázáshoz 3\% B oszlopot (Waters Symmetry C18 $180 \mu \mathrm{m} \times 20 \mathrm{~mm}$ oszlop, $5 \mu \mathrm{m}$ partikulum méret, $100 \AA$ pórusméret, folyási sebesség: $10 \mu \mathrm{l} / \mathrm{min}$ ) használtunk majd a peptideket 10-40\%-os B lineáris gradiensen szeparáltuk 90 percen keresztül ( $75 \mu \mathrm{m} \times 104$ mm oszlop MagicC18AQ, $3 \mu \mathrm{m}$ partikulum méret, 200 Å pórusméret, solvent A $0.1 \%$ hangyasav/víz elegyével, solvent B comprising $0.1 \%$ hangyasav/ACN elegyével, folyási sebesség: $400 \mathrm{nl} / \mathrm{min}$ ). A 10 legnagyobb mennyiségbn jelen lévő többszörösen töltött ionokat választottuk ki minden egyes MS szkenből (m/z: 380-1600), amelyeken MS/MS analízist végeztünk CID (Collision-induced dissociation) aktivációval (normalizált ütközési energia:35). Az MS spektrumokat Orbitrap készülékből, míg a CID spektrumokat lineáris ion csapdázóból nyertük. A nyers adatokat átalakítottuk PAVA program segítségével és a kereséshez a Protein Prospector (v.5.19.4.) programot használtuk. Az azonosított peptidszekvenciákat az Uniprot adtabázisban (2016/09/06 verzió, 42488 fehérje szekvencia) lévő Drosophila melanogaster fehérjék szekvenciáihoz illesztettük. A fehérjék relatív mennyisége az egyes mintákban megbecsülhető az ún. spektrumszámlálás módszerével. Ehhez először meghatározzuk, hogy az adott mintasorozaton belül egy adott fehérjére összesen hány azonosított peptid esik, illetve ezt a számot elosztjuk az összes azonosított peptidszámmal. A kapott hányados mintasorozatok közötti összehasonlításával megbecsülhető az adott fehérje mennyiségi változása, ha a normalizált peptidszámok hányadosa a medián érték $0.5 *$-énél kisebb vagy $2 *$-énél nagyobb, akkor tekintjük mérvadónak a változást. Azokat a fehérjéket tekintettük pozitív találatnak, amelyeket legalább 3 egyedi peptiddel azonosítottunk a dDAAM::Flag-et tartalmazó mintában.

\section{Elektronmikroszkópia}

A kiboncolt lárvefiléket előfixáltuk (10 perc; 4\% PFA és 0.5\% glutáraldehid 0.1 M PBS-ben), majd glutáraldehiddel (60 perc; $2 \%$ glutáraldehid in $0.1 \mathrm{M} \mathrm{Na}^{+}$-kakodilát) tovább fixáltuk. A kakodilát pufferes mosást követően posztfixálást végeztünk ( $1 \%$ ozmium-tetroxid, $0.8 \%$ $\mathrm{K}_{4} \mathrm{Fe}(\mathrm{CN})_{6}, 0.1 \mathrm{M} \mathrm{Na}^{+}$-kakodilát puffer). A kakodilát pufferes és vizes mosást követően $1 \%$ uranil acetáttal festettük a mintákat. A mintákat alkohol sorban dehidratáltuk, majd Epon 
mügyantába ágyaztuk. A mügyanta polimerizációt követően az öntőformákon 60-65 nm-es vastag szériákat készítettünk, amelyeket posztfixáltuk és festettük uranil-acetáttal, illetve ólomcitráttal. A képeket JEM 1011; JEOL elektronmikroszkóppal készítettük Orius 1200A; Gatan kamerával. A T-barok elemzését manuálisan végeztük. A T-barok, boutonok és egyedi állatok száma a következő volt: T-bar: $w^{1118}=84, d D A A M^{E x 68}=72$; bouton: $w^{1118}=74, d D A A M^{E x 68}=67$; egyedi állat: $w^{1118}$ és $d D A A M^{E x 68}: 6$

\section{Elektrofiziológia}

TEVC méréseket 3. stádiumos hím lárvákon végeztük el $25^{\circ} \mathrm{C}$-on. A boncolást és a TEVC méréseket is HL3 (haemolymph-like solution 3) oldatban (összetétel mM-os koncentrációban: $70 \mathrm{NaCl}, 5 \mathrm{KCl}, 20 \mathrm{MgCl}_{2}, 10 \mathrm{NaHCO}_{3}, 5$ trehalóz, 115 szukróz, 5 HEPES, pH 7.2) végeztük el. A boncolást $\mathrm{Ca}^{2+}$ mentes HL3 oldatban, míg a méréseket $1.5 \mathrm{mM}$-os $\mathrm{Ca}^{2+} \mathrm{HL} 3$ oldatban végeztük $25^{\circ} \mathrm{C}$-on. A kiváltott EPSP-t és a mini excitatorikus áramokat a 6/7 izmoknál a 2. és 3. abdominális szegmentben mértük. A mini excitatorikus áramokat $-80 \mathrm{mV}-$ os feszültségzárral, míg a kiváltott EPSP-t -60 mV-os feszültségzárral mértük 0.2 Hz-es serkentés mellett. Csak azokat a sejteket használtuk további mérésekre, amelyeknek a kezdeti membránpotenciálja -50 és $-70 \mathrm{mV}$ közötti, illetve a belső ellenállása $\geq 4 \mathrm{M} \Omega$ volt.

\section{Képvizsgálat és elemzés}

A konfokális képeket Olympus FV-1000 Laser Scanning Microscope (LSM) vagy Zeiss LSM 880 mikroszkópokkal készítettük. A képek minőségét Huygens deconvolution szoftver (Scientific Volume Imaging B.V.) használatával javítottuk. ImageJ/Fiji program alkalmazásaival mértük meg az NMJ különböző paramétereit.

\section{A bouton szám, az NMJ hossz és az izomterület meghatározása}

A 4-es és 6/7-es izomhoz tartozó NMJ-ket vizsgátuk az A2-5 szegmentekben legalább 10 egyedi állattal minden egyes genotípus esetén. 2 vagy 3 NMJ-t használtunk állatonként a bouton szám, az NMJ hossz, illetve az izomterület meghatározásához, ezáltal legalább 25 egyedi NMJt vizsgáltunk a genotípusok paramétereinek meghatározásához. Egy boutonnak tekintettünk minden kerek vagy ovális struktúrát a motoraxon végződésen az anti-HRP/Dlg immunfestés alapján. Az NMJ hosszának az NMJ két legtávolábbi pontjának távolságát tekintettük anti-HRP immunfetés alapján. Az izom területét a Dlg festés alapján állapítottuk meg a Fiji sokszög kijelölő eszköz segítségével. 
Az inter-bouton régió az $\mathrm{NMJ}$ azon része, amely hídszerü struktúraként összeköt 2 szomszédos boutont. Az inter-bouton rész vad típusú NMJ-ben rendszerint keskenyebb a boutonoknál és a mikrotubulus köteg teljesen kitölti. Ezzel ellentétben a $d D A A M$ mutáns NMJ-ben az interbouton régió kiszélesedik és az abban található mikrotubulus köteg fragmentálódik. Az interbouton régió meghatározásához a 4-es izomhoz tartozó NMJ középső részét használtuk a 2. és 3 abdomnális szegmentben. A mérésekhez 3 szomszédos inter-bouton régiót használtunk minden egyes mintában; az inter-bouton régiók maximális átmérőjével számoltunk az anti-HRP immunfestés alapján. Minden egyes genotípus esetén 15 mintát vizsgáltunk (45 interbouton régió).

A mikrotubulus organizációjának a meghatározása a terminális boutonokban

A legtöbb vad típusú boutonban a mikrotubulus jól detektálható, leginkább szabálytalan módon szétterül vagy alacsony előfordulási gyakorisággal alig észlelhető anti-Futsch immunfestést használva. A terminális boutonokról készített képeket (30. ábra A-C) ugyanazokkal a beállításokkal készítettük használva a detektorok teljes dinamikus tartományát, így elkerülve a jelintenzitás túltelítettségét. A 30. ábra $\mathrm{Ab}, \mathrm{Bb}$ és $\mathrm{Cb}$ paneljein Fiji programmal a fényerô és a kontraszt lineáris változtatásával megjelenítettük azt az információt, ami eredetileg is megtalálható volt a kiindulási képeken (30. ábra A-C). Minden egyes genotípusnál legalább 25 terminális boutont vizsgáltunk és a vad típus esetén a boutonok kb. 86\%-ban detektáltunk mikrotubulus organizációt, míg a $d D A A M$ mutánsok esetén ez csak kb. 40\% volt.

\section{STED mikroszkópia}

A minta előkészítést és a festést egy korábbi közlemény módszertanának megfelelően végeztük el [187]. A lárvafiléket 5 percig fixáltuk hideg metanolban. A 2 órás blokkolást követően a következő elsődleges ellenanyagokat használtuk: egér anti-Brp C-term. (DSHB, nc82) (1:100), nyúl anti-Brp N term. [184] (1:1000), nyúl anti-dDAAM-R1 [228] (1:2000). A következő másodlagos ellenanyagokat használtuk: anti-egér-Atto647N (1:500), anti-nyúl-Alexa594 (1:500). A megfestett lárvafiléket ProLong Gold antifade reagens használatával tettük tárgylemezre. A kétcsatornás STED képeket TCS SP8 gSTED (Leica Microsystems) mikroszkóppal készítettük. HC PL APO CS2 100x objektívet használtunk (oil immersion, NA: 1.4). A STED képeket LAS X software (Leica Microsystems) segítségével generáltuk, majd 
Huygenes Professional program segítségével dekonvolváltuk. Az ImageJ program varázspálca eszközét használtuk a Brp gyürü átméröjének meghatározásához.

\section{Statisztikai elemzés}

Az adatokat Prism program segítségével elemeztük (Version 5, GraphPad Software). Két csoport összehasonlításához két mintás t-próbát vagy Mann-Whitney $U$-próbát használtunk. ANOVA programot többszörös összehasonlításhoz használtuk. $p<0.05$ esetén statisztikailag szignifikáns különbségről beszélünk $\left({ }^{*} \mathrm{p}<0.05, * * * p<0.001\right)$. Az oszlopok átlagértékeket ábrázolnak a szórások feltüntetésével. Az adatok valószínüleg normál eloszlásúak, de formálisan nem voltak tesztelve.

\section{Primer lista}

\begin{tabular}{|c|c|c|}
\hline Primer név & Szekvencia & Felhasználás \\
\hline dDAAM-732-F & $\begin{array}{l}\text { CACCGCTCTGCTGAGCAAAC } \\
\text { TG }\end{array}$ & $U A S-F L D A A M^{732}$ \\
\hline dDAAM-732-R & CAGTTCTGCGCCCGACGTCC & $U A S-F L D A A M^{732}$ \\
\hline dDAAM-876-881-F & GACACCGCGTCCAGTGCCG & $U A S-F L D A A M^{876-881}$ \\
\hline dDAAM-876-881-R & CGCCAGCGCGTTGAGTGAC & $U A S-F L D A A M^{876-881}$ \\
\hline $\begin{array}{l}\text { dDAAMFH2-shRNS- } \\
\text { F }\end{array}$ & $\begin{array}{l}\text { CTAGCAGTGAGCGACATGGA } \\
\text { GATATCAAATAGTTATATTC } \\
\text { AAGCATATTTGATATCTCCAT } \\
\text { GTCGCTCGCG }\end{array}$ & $U A S-s h R N S-d D A A M F H 2$ \\
\hline $\begin{array}{l}\text { dDAAMFH2-shRNS- } \\
\text { R }\end{array}$ & $\begin{array}{l}\text { AATTCGCGAGCGACATGGAG } \\
\text { ATATCAAATATGCTTGAATA } \\
\text { TAACTATTTGATATCTCCATG } \\
\text { TCGCTCACTG }\end{array}$ & $U A S-s h R N S-d D A A M F H 2$ \\
\hline pCFD4-Futsch-1F & $\begin{array}{l}\text { TATATAGGAAAGATATCCGG } \\
\text { GTGAACTTCGCAGCTGGCCC } \\
\text { AGTTCCTGAGTTTTAGAGCT } \\
\text { AGAAATAGCAAG }\end{array}$ & $\begin{array}{l}\text { futsch }^{C R 13}, d D A A M^{E x 68}, \\
\text { futsch }^{C R 13}\end{array}$ \\
\hline pCFD4-Futsch-3R & $\begin{array}{l}\text { ATTTTAACTTGCTATTTCTAG } \\
\text { CTCTAAAACGCCCGCTCACC } \\
\text { GGCTGCTACGACGTTAAATT } \\
\text { GAAAATAGGTC }\end{array}$ & $\begin{array}{l}\text { futsch }^{C R 13}, d D A A M^{E x 68}, \\
\text { futsch }^{C R 13}\end{array}$ \\
\hline
\end{tabular}




\section{FONTOSABB RÖVIDÍTÉSEK}

$\gamma$-TuRC $-\gamma$-tubulin ring complex, $\gamma$-tubulin gyürü komplex

+TIP - microtubule plus-end tracking proteins, $(+)$ végkötő fehérjék

$\mathrm{ACh}$ - acetyl-choline, acetil-kolin,

AP - akciós potenciál

APC - adenotamous polyposis coli

Arp - actin-related protein

CC - coiled-coil

CAM - cell adhesion proteins, sejtadhéziós fehérjék

C-DAAM - konstitutívan aktív, C-terminális DAAM

CLASP - CLIP-associated protein

Cobl - Cordon-bleu

DAAM - dishevelled associated activator of morphogenesis

DAD - diaphanous autoregulatory domain

DD - dimerization domain

dDAAM - Drosophila DAAM

Dia - Diaphanous

DID - diaphanous inhibitory domain

Dlg - Disc large

DRF - diaphanous related formin

Dsh - Dishevelled

EB - end binding, végkötő

EPSP - excitatory postsynaptic potential, excitatorikus posztszinaptikus potenciál

F-aktin - aktin filamentum

FH1 - formin homology 1

FH2 - formin homology 2

FHOD - formin homology domain proteins

FMN - formins

FMNL - formin-like proteins

G-aktin - aktin monomer

GBD - GTPase-binding domain

GFP - green fluorescent protein, zöld fluoreszcens fehérje

GluR - glutamát receptor 
HIK - hasi idegköteg

INF - inverted formins

ISN - intersegmental nerve, interszegmentális ideg

KIR - központi idegrendszer

Lmod - Leiomodin

MAP - microtubule associated protein, mikrotubulus-asszociált fehérje

MCAK - mitotic centromere-associated kinesin, mitotikus centromer asszociált kinezin

NMJ - neuromuscular junction, ideg-izom kapcsolat

NPF - nucleation-promoting factor

PBS - phosphate buffered saline

PCP - planar cell polarity

PRD - prolin-rich domain

Sgg - Shaggy

$\mathrm{SN}$ - segmental nerve, szegmentális ideg

SSR - subsynaptic reticulum, szubszinaptikus retikulum

STED - super-resolution stimulated emission depleted

SV - synaptic vesicle, szinaptikus vezikula

SxIP - szerin, $x$ aminosav, ileucin, prolin aminosavakból álló tetrapeptid motívum

TEVC - two-electrode voltage clamp

TN - transverse nerve, transzverzális ideg

WASP - wiscott-aldrich syndrome protein

WH2 - WASP homology 2 domain 


\section{KÖSZÖNETNYILVÁNÍTÁS}

Szeretnék köszönetet mondani Dr. Mihály Józsefnek, hogy 2008-ban csatlakozhattam a csoportjához. Köszönöm a lehetőséget, a sok rám fordított energiát, türelmet, és a rengeteg segítséget.

Köszönettel tartozom Dr. Gombos Ritának, aki diákkörös témavezetésem vállalta magára, és elindított a kutatói pálya rögös útján. Köszönöm a rengeteg átadott szellemi és technikai tudást, a sok jó tanácsot, a szakmai és baráti beszélgetéseket, és hogy megmutatta azt a szemléletet, amivel igazán jó kutatóvá válhat az ember.

Szeretném megköszönni Dr. Szikora Szilárdnak és Dr. Földi Istvánnak a kísérletekben és az első szerzős cikk megírásában nyújtott segítséget. Külön köszönöm azokat a vitákat és beszélgetéseket, amelyeket folytattunk számos tudományos kérdésről, illetve az élet különböző területeiröl.

Köszönöm továbbá Berente Anikónak, Csendesné Aninak, Gyáni Editnek és Velkeyné Krausz Ildikónak a rengeteg technikai segítséget, amivel könnyebbé tették számomra a labormunkát.

Köszönöm Gerhát Gabinak, Farkas Dávidnak, Kaltenecker Péternek és Tóth Krisztinának a szakmai segítségüket és a hasznos beszélgetéseiket.

Köszönettel tartozom továbbá a laborunk egykori tagjainak, hogy mindenben segítettek, amiben tudtak.

Köszönöm Dr. Hegyi Péternek és Dr. Maléth Józsefnek, hogy az I. számú Belgyógyászati Klinikán használhattam a konfokális mikroszkópjukat.

Köszönöm a pécsi partnereinknek, Dr. Nyitrai Miklósnak, Dr. Bugyi Beátának, Dr. Tóth Mónika Ágnesnek, Dr. Huber Tamásnak, Dr. Barkó Szilviának és Leipoldné Vig Andreának, hogy érdekes tudományos témákon dolgozhattunk együtt.

Köszönöm a berlini együttmüködő partnereinknek, Dr. Stephan Sigristnek és Torsten Götznek az áldozatos munkájukat, amely rendkívül sokat javított az első szerzős cikkem szakmai minőségén. Továbbá köszönöm a segítséget a Sigrist labor többi tagjának is; Mathias Böhmenak, Janine Lützkendorfnak, Malou Mampellnak és Christina Hollmannak. 
Szeretném megköszönni Dr. Udvardy Andornak, Pintér Lajosnak, Dr. Sipos László Attilának, Dr. Darula Zsuzsannának, Dr. Siklós Lászlónak, Dr. Juhász Gábornak, Dr. Kovács Leventének és Dr. Medzihradszky Katalinnak a sok szakmai segítséget és hasznos tanácsot, amit itt a Biológiai Kutatóközpontban adtak.

Szeretnék köszönetet mondani egykori tanáraimnak, akik erősítették bennem a természettudományos pálya iránti szeretetemet. Kiemelném gimnáziumi tanáraimat, Modok Balázsné kémia, Varga-Sabjánné Szabó Sarolta biológia tanáromat, valamint Dr. Tamás Gábor és Dr. Szente Magdolna egyetemi tanáraimat, akiknek köszönhetően ragadott meg véglegesen e tudományterület szépsége.

Köszönöm Dr. Honti Viktornak és Dr. Jankovics Ferencnek, amiért rövid határidővel elvállalták a dolgozatom bírálatát.

Köszönöm az SZBK hatodik emeleti Drosophila közösségének, hogy szakértelmükkel és segítségükkel hozzájárultak a dolgozat létrejöttéhez. Külön köszönöm Dr. Gyurkovics Henriknek a gyakran éjszakába nyúló, rendkívül tanulságos és érdekfeszítő diskurzusokat.

Köszönöm az SZBK Genetikai Intézet vezetőinek, és minden tagjának, akik valamilyen módon szakmai segítséget nyújtottak a munkám során.

Köszönöm továbbá a Szegeden élő külföldi kutatóknak, Arno Dobisnak, Sergio Castelvetranonak, Imran Abou Babanak, Amin Al-awarnak, Jacoob Mirnek és Ahmed Al-Janabinak a rengeteg hasznos szakmai segítséget, valamint az érdekes beszélgetéseket.

Végezetül szeretném megköszönni a családomnak, a rokonaimnak, és a barátaimnak, hogy mindig mellettem álltak, és mindenben számíthattam rájuk. Köszönöm!

\section{FINANSZÍROZÁS}

A munkámat a Nemzeti Kutatási, Fejlesztési és Innovációs Hivatal pályázatai (GINOP-2.3.215-2016-00001 és GINOP-2.3.2-15-2016-00032) támogatták. 


\section{ÖSSZEFOGLALÁS}

Az agyban kialakuló milliárdnyi szinaptikus kapcsolat nélkülözhetetlen feltétele annak, hogy bonyolult idegi hálózatok alakuljanak ki. A szinaptikus fejlődés és a funkció mechanizmusainak a vizsgálatával jobban megérthetünk olyan komplex idegi folyamatokat, mint pl. a tanulás, a memória és az érzékelés. Az utóbbi évtizedek neurobiológiai kutatásai fényt derítettek arra, hogy a szinaptikus fejlődés, funkció és struktúra fenntartás bonyolult folyamataiban a sejtváz dinamikus átrendeződése is fontos szerepet játszik ebben. Annak ellenére, hogy számos olyan fehérjét ismerünk, amely képes szabályozni az aktin és a mikrotubulus szerveződést, még nagyrészt ismeretlen a sejtvázszabályozás mechanizmusainak a többsége a szinaptikus fejlődés során. A tudásunk folyamatosan bővül új upstream sejtvázszabályozó elemek megismerésével, viszont még keveset tudunk arról, hogy a sejtváz effektor fehérjék miként kötődnek az aktin/mikrotubulus sejtvázhoz és hogyan szabályozzák azokat. A sejtváz effektor fehérjék vizsgálatával jobban megérthetjük a sejtváz-átrendeződések dinamikus folyamatait.

Néhány évvel ezelőtt kezdtük el vizsgálni a Drosophila DAAM, formin típusú sejtvázszabályozó fehérje szerepét neuronális folyamatokban. Számos Drosophila neuronális modellrendszert használva megállapítottuk, hogy a dDAAM az aktin összeszerelő aktivitása révén szerepet játszik az axon növekedés és navigáció folyamataiban. Később számos bizonyítékot adtunk arra vonatkozólag, hogy a dDAAM képes közvetlenül kötődni a mikrotubulusokhoz, valamint szerepe lehet az aktin/mikrotubulus kölcsönhatások elősegítésében. Tovább folytatva ezt a munkát, a dolgozatban a dDAAM szerepét vizsgáltam a szinaptikus fejlődés folyamataiban.

Először megállapítottuk, hogy a dDAAM a szinapszisképződés egyik korai szereplője, már az embrionális fejlődés során szükség van a fehérje kifejeződésére. A dDAAM fehérje hiányában az embrionális motoraxon növekedési és navigálási hibát egyaránt mutat az NMJ terminálisoknál. A vizsgálatainkat kiterjesztve a lárvális NMJ végződések vizsgálatára megállapítható, hogy a dDAAM pre- és posztszinaptikus kifejeződést egyaránt mutat. A dDAAM mutáns NMJ terminális lárvában abnormális fejlődést mutat bouton szám és NMJ morfológia tekintetében. A dDAAM hiányos motoraxon végződések drasztikus bouton szám 
csökkenést mutatnak, illetve a boutonokat összekötő inter-boutonikus régió kiszélesedik bouton fúziós fenotípust eredményezve. Habár a dDAAM mindkét szinaptikus oldalon kifejeződik, további funkcióvesztéses vizsgálatokból kiderült, hogy a látott NMJ fenotípusokat elsősorban a dDAAM preszinaptikus hiánya okozza

Annak érdekében, hogy jobban megértsük a dDAAM preszinaptikus szerepét az NMJ fejlődés során, elhatároztuk, hogy megvizsgáljuk a sejtvázszerveződést az NMJ terminálisokban. Mivel a Futsch, mint preszinaptikus mikrotubulus marker a legígéretesebb dDAAM kölcsönható partnernek tünt, ezért a mikrotubulus rendszert vizsgáltuk először a dDAAM mutánsokban. A vad típusú preszinaptikus motoraxon végződésben megfigyelhető, hogy a központi mikrotubulus sejtváz egy egységes kötegbe rendeződik, amely fokozatosan a preszinaptikus végződés disztális része felé haladva elvékonyodik. Ezzel ellentétben a dDAAM hiányában fragmentált és dezorganizált szerveződést mutat a központi mikrotubulus köteg, valamint a terminális boutonokból gyakran hiányoznak a mikrotubulusok. A forminokat eddig főként aktin polimerizációs faktorként ismertük, de az utóbbi időben egyre több eredmény áll rendelkezésünkre arra vonatkozólag, hogy képesek szabályozni a mikrotubulusokat is. Ezek alapján úgy gondoltuk, érdekes lenne megvizsgálni, hogy vajon a dDAAM aktin és/vagy mikrotubuluskötő funkciója fontos-e a bouton képződésben. A kérdés megválaszolásához menekítési kísérleteket végeztünk olyan teljes hosszúságú dDAAM pontmutáns fehérjékkel, amelyek nem képesek az aktinhoz vagy az aktinhoz és a mikrotubulusokhoz kötődni. A vad típusú és az aktin inkompetens teljes hosszúságú dDAAM fehérje képes volt menekíteni a $d D A A M$ mutáns NMJ fenotípusát, ezzel szemben az aktin és mikrotubulus kötésre képtelen kettős mutáns nem volt képes helyreállítani a vad típusú NMJ morfológiát. Ez után felmerült bennünk a kérdés, hogy a $d D A A M$ mutáns NMJ-ben vajon a preszinaptikus aktin organizáció érintett-e. A $d D A A M$ mutáns preszinaptikus motoraxon végződésben az aktin szerveződés a vad típushoz nagyon hasonló volt. Ezek az eredmények megerősítettek bennünket abban, hogy a dDAAM elsődleges funkciója a mikrotubulus sejtvázszabályozáshoz köthető az NMJ fejlődés során, míg az aktin összeszerelő aktivitása nem tünik fontosnak a szinaptikus bouton képződés folyamataiban.

A funkcióvesztéses kísérletek alapján a dDAAM preszinaptikus jelenléte képes elősegíteni a bouton képződést. A továbbiakban kíváncsiak voltunk arra, hogy ha a fehérje 
aktivitását megemeljük, akkor annak milyen hatása lesz az NMJ morfológiára vagy a bouton képződésre. Korábbi kísérleteink során sikerült a dDAAM N-terminális részének az eltávolításával egy konstitutívan aktív dDAAM formát létrehoznunk, amit C-DAAM-nak hívunk. A C-DAAM preszinaptikus túltermelése jelentős mértékben megemelte a bouton számot, ami megerősíti azt az elképzelésünket, hogy a dDAAM-nak meghatározó szerepe van a boutonok kialakulásában.

Miután bebizonyítottuk, hogy a dDAAM a bouton képződés pozitív szabályozó faktora, érdekesnek tartottuk megvizsgálni, hogy a szinapszisképződésben részt vevő másik formin típusú fehérje a Dia befolyásolja-e a dDAAM NMJ fejlődésben betöltött szerepét. A Dia preés posztszinaptikus kifejeződést egyaránt mutat és elősegíti a bouton képződést. A dia mutánsokban a bouton szám csökkenése, valamint a boutonikus régió növekedése figyelhető meg. A Dia fehérje hiánya a preszinaptikus oldalon az aktin és a mikrotubulus szerveződést egyaránt befolyásolja. A genetikai interakciós kísérleteink alapján a Dia és a dDAAM függetlenül müködik a szinaptikus bouton képződésben. Ezt megerősíti, hogy a Dia-tól eltérően a $d D A A M$ nem mutat genetikai kölcsönhatást a trio-val transzheterozigóta mutáns kombinációban. Összességében elmondható, hogy a dDAAM szinaptikus müködésmódja a Dlar/Trio/Dia szignalizációs egységtől valószínüleg független.

Ezek után kíváncsiak voltunk arra, hogy a dDAAM müködését milyen jelátviteli útvonalak szabályozzák. A genetikai interakciós vizsgálatok alapján a dDAAM együttműködhet a Wg és az Ank2 fehérjékkel az NMJ fejlődés során. Érdekes módon korábban már leírták, hogy a dDAAM tagja lehet a Wnt/Fz jelátviteli útnak különbözö szövetekben. Illetve azt is tudjuk, hogy a divergens kanonikus Wnt/Wg jelátviteli út az Ank2-vel együtt szabályozza a preszinaptikus mikrotubulus organizációt. A fenti adatok megerősítik azt az elképzelésünket, hogy a dDAAM a Wg és az Ank2 fehérjékkel együttmüködik a megfelelő NMJ morfológia létrehozásában. Korábbi kísérletekben bemutatták, hogy az Ank2 valószínűleg a Wg szignalizáció egyik effektor fehérjéje az NMJ terminális kialakulásában. Így érdekesnek találtuk megvizsgálni a dDAAM helyzetét ebben a hierarchia rendszerben episztázis kísérletek használatával. A korábbi eredményekkel összhangban az Ank2 null mutáns állatokban csökkent bouton szám és nagymértékü mikrotubulus felhalmozódás volt megfigyelhető az NMJ végződésekben. Ezzel szemben a kettős homozigóta $d D A A M$; Ank2 mutánsokban a dDAAM 
hiánya képes volt megszüntetni az Ank2 mutánsra jellemző mikrotubulus felhalmozódást, valamint az inter-boutonikus régió kiszélesedését. A kísérletek alapján a dDAAM episztatikus az Ank2-höz képest, valamint a dDAAM mikrotubulus stabilizáló szerepe ebben a hierarchia rendszerben valószínűleg downstream szabályozó elemként viselkedik. A dDAAM; Ank2 kettős mutáns fenotípusa viszont nem teljesen azonos a $d D A A M$ mutáns NMJ fenotípusával, ami arra utal, hogy nem egy egyszerü alá-fölé rendeltségi viszony van a két fehérje között. Az Ank2 mellett a mikrotubuluskötő Futsch fehérjéről is ismert, hogy a szinaptikus Wg szignalizáció egyik effektor molekulája. Hasonlóan az Ank2-höz a Futsch esetében is $d D A A M / f u t s c h$ kettős mutáns NMJ végződéseket vizsgáltunk, hogy jobban megértsük a dDAAM szerepét vagy helyzetét a divergens kanonikus Wg szignalizációban. A kettős mutáns NMJ végződésekben csökkent bouton szám, bouton fúzió valamint szakadozott mikrotubulus kötegek jelentek meg, ami nagyon hasonlított a $d D A A M$ fenotípusra. A fenti eredmények alapján a $d D A A M$ episztatikus a futsch-hoz képest.

Tovább folytatva a lokalizációs vizsgálatokat megállapítottuk, hogy a dDAAM fehérje a kortikális felhalmozódás mellett a preszinaptikus oldalon egy pöttyszerü kifejeződési mintát is mutat. Tovább vizsgálva ezt az érdekes pöttyszerủ kifejeződési mintázatot, nagy felbontású STED mikroszkópiával megállapítottuk, hogy a dDAAM felhalmozódás egy gyürüszerü struktúrát rajzol ki, ami nagyrészt átfed a Brp C-terminális fehérjerész mintázatával, ami az aktív zóna fehérjekomplex disztális vége. A lokalizációs vizsgálatok mellett funkcionális bizonyítékokat is találtunk arra vonatkozólag, hogy a dDAAM befolyásolhatja az aktív zóna kialakulását, illetve annak működését. Megvizsgálva az aktív zónák ultrastruktúrális szerkezetét a $d D A A M$ mutáns állatokban az aktív zóna átmérője kis mértékben megnőtt. Végezetül elektrofiziológiai mérésekkel megvizsgáltuk azt, hogy a dDAAM hiánya befolyásolja-e a szinaptikus transzmisszió hatékonyságát. Habár a spontán szinaptikus áramok karakterisztikájában nem láttunk változást, a kiváltott akciós potenciál mértéke kisebb volt dDAAM hiányában.

Ebben a munkában bemutattuk azt, hogy a formin típusú sejtvázszabályozó dDAAM fehérje képes elősegíteni az új bouton képződést és úgy tünik, hogy moduláris funkcióval bír az aktív zóna képződésben és funkcióban. 


\section{SUMMARY}

The building of complex neuronal circuits requires the formation of billions of synaptic connections in the brain. Elucidating synapse development and function is essential to understand cognitive processes such as learning, memory and perception. Over the last decades, a significant body of literature on the neuroscience has revealed that the dynamic cytoskeletal rearrangement is crucial for the stabilization and the remodeling of the synaptic connections. Despite the identification of numerous proteins that regulate actin and microtubule organization, the mechanisms of cytoskeletal control during synapse development have remained largely elusive. Our knowledge of the upstream cytoskeletal regulators is permanently growing, so we are starting to better understand how they function during synaptogenesis. However, much less is known about how the cytoskeletal effectors regulate the major elements of the cytoskeleton. A few years ago, we began to investigate the role of a formin type of cytoskeleton regulatory protein, Drosophila DAAM, during neuronal development. By using different Drosophila neuronal model systems we have shown that the actin assembly activity of dDAAM is required for axonal growth and guidance. Later, we have provided several pieces of evidence that dDAAM is able to bind directly to the microtubules and plays a role in the coordination of actin/microtubule crosstalk. As an extension of these studies, here we investigated the role of dDAAM during NMJ development in Drosophila.

To address whether dDAAM might be involved in synaptogenesis, firstly we examined the role of dDAAM during embryonic NMJ development. We revealed that dDAAM is highly enriched at the motoraxon terminals and the lack of dDAAM causes defects in motorneuron growth and guidance in the embryos. These data suggest that the dDAAM protein might indeed be required for the early steps of synaptic development. We next analyzed the larval NMJs and showed that dDAAM is present on both the pre- and postsynaptic sides. Moreover, in the dDAAM mutant NMJs we observed a decreased synaptic bouton number and abnormal NMJ morphology with stretched inter-bouton regions, often designated as a bouton fusion phenotype. Although dDAAM is expressed in both synaptic compartments, further mutational analyses argue for a primarily presynaptic role. 
To gain deeper insights into presynaptic role of dDAAM in NMJ development, a set of experiments was carried out to analyze the underlying cytoskeleton in the motoraxon terminals. After large scale affinity purification and MS analysis, the Futsch protein which is a widely used microtubule marker in the NMJ, appeared to be the most promising interaction partner of dDAAM. Previous findings have established that Futsch is able to promote microtubule stabilization and new bouton formation; therefore we tested whether lack of dDAAM affects presynaptic microtubule organization. In wild type NMJs the presynaptic microtubules are organized into a prominent bundle of core filaments that becomes gradually thinner in the distal region of the presynaptic motornerve terminal. By contrast, the $d D A A M$ null mutation results in fragmentation of the core microtubule bundle and the microtubules are often absent from the terminal boutons. Although formins are best known for their ability to promote actin filament assembly, a mounting body of evidence supports that they are also involved in microtubule regulation; in particular, they have been implicated in microtubule stabilization in many cellular model systems. Hence, we tested which dDAAM activities are important for NMJ development. We carried out a series of rescue experiments with point mutant versions of the full-length dDAAM protein, in which we impaired actin interaction alone or actin and microtubule interactions together. The wild type and actin incompetent form of dDAAM rescued the $d D A A M$ mutant NMJ phenotype while the actin and microtubule double mutant failed to restore the wild type NMJ morphology. In accordance with this, $D D A A M$ mutant $\mathrm{NMJ}$ terminals do not appear to exhibit major alterations in presynaptic actin organization. These data suggest that the primary function of DAAM during NMJ development is presumably linked to its microtubule organizing role, whereas its actin filament assembly activity is likely to be dispensable for synaptic bouton formation.

To corroborate the presynaptic requirement of dDAAM for promoting bouton formation, we tested whether an increased activity of dDAAM affect synaptic bouton formation. We previously showed that removing the $\mathrm{N}$-terminal part of dDAAM results in a constitutively active form, called C-DAAM. The presynaptically overexpressed C-DAAM caused an increase in bouton number at the NMJ terminals reinforcing further that this protein plays an instructive role in bouton formation. 
After having demonstrated that dDAAM is a positive regulatory factor of bouton formation, we next wanted to examine whether there is a functional redundancy between dDAAM and Dia, another formin linked to synapse development. Dia is expressed both presynaptically and postsynaptically and has a presynaptic function in bouton formation. The lack of Dia leads to a decrease in bouton number with an increase in bouton area. Aberrations were reported in both the actin and microtubule organization on the presynaptic side. Based on our genetic interaction studies, Dia and dDAAM are likely to function independently during NMJ development. In agreement with this, unlike dia, $d D A A M$ does not exhibit an interaction with trio in a transheterozygous mutant combination, and it appears likely that dDAAM is controlled independently of the Dlar/Trio/Dia module.

We next aimed to decipher which signaling pathways control the activity of dDAAM. Our genetic interaction experiments suggested that dDAAM works together with $\mathrm{Wg}$ and Ank2 during NMJ development. Interestingly, dDAAM has previously been linked to Wnt/Frizzled signaling in other cellular contexts. Furthermore, prior studies have revealed that presynaptic $\mathrm{Wg}$ signaling regulates the synaptic microtubule cytoskeleton in conjunction with Ank2. Thus, these data support the notion that dDAAM acts in concert with Wg and Ank2 during synapse development. It has previously been shown that Ank2 is likely to be a downstream factor of Wg signaling in NMJ development. Consequently, we attempted to determine the place of dDAAM in this hierarchy by epistasis analysis. In accordance with previous studies, Ank2 null mutant NMJs displayed reduced bouton numbers with bouton fusions and strong microtubule accumulations in the presynaptic terminal. By contrast, in the double homozygous $D D A A M$; Ank2 animals the absence of dDAAM was able to suppress the microtubule aggregation phenotype of Ank2 and only a weak central microtubule bundle formed, and boutons no longer exhibited a fused appearance. These data regarding microtubule organization suggest that dDAAM is epistatic to Ank2, which implies a downstream regulatory position as a microtubule stabilization factor. The NMJ morphology and microtubule organization of $D D A A M$; Ank2 double mutants are not identical to any of the single mutants suggesting a more complex interaction between dDAAM and Ank2 than a simple linear pathway. In addition to Ank2, the microtubule associated Futsch protein has also been shown to be a downstream effector protein of Wg signaling in synaptic growth. Similarly to Ank2, we examined futsch/dDAAM double 
mutant NMJ terminals to determine the place of dDAAM in this divergent canonical $\mathrm{Wg}$ signaling pathway. The double mutant NMJs strongly resembled those of $\triangle D A A M$ single mutants, with significantly reduced bouton numbers, the presence of bouton fusions, and fragmented microtubule organization. Hence, $D D A A M$ is clearly epistatic to futsch, and these results argue for dDAAM acting either downstream of Futsch or in a parallel pathway.

Using two different anti-dDAAM antibodies we revealed that besides its cortical accumulation, dDAAM is strongly expressed at the presynaptic terminal, forming a spot-like pattern. The application of STED microscopy allowed us to determine that dDAAM is enriched in a ring-like pattern in the immediate vicinity of the C-terminus of Brp, the distal part of active zone complex. Furthermore, we have shown that the presence of Brp is required for dDAAM localization at the active zone, but not vice versa. Moreover, we have proposed several lines of evidence that lack of dDAAM affects active zone formation and function. Although the lack of dDAAM has no major effect on active zone organization, active zones were slightly bigger in dDAAM mutant synapses. Finally, electrophysiological experiments were carried out to investigate whether $D D A A M$ could influence the efficiency of synaptic transmission due to its prominent localization close to the sites of neurotransmitter release. Although spontaneous release was not altered, we observed a significant reduction in evoked excitatory NMJ currents. Collectively, these data suggest that dDAAM is strongly associated with the active zone scaffold, and its absence impairs synaptic vesicle release.

Our work described that dDAAM, a formin type of cytoskeleton regulatory protein, is able to promote the new synaptic bouton formation and appears to have a modulatory role during the formation and functioning of the active zones. 


\section{IRODALOMJEGYZÉK}

1. Pollard, T.D., L. Blanchoin, and R.D. Mullins, Molecular mechanisms controlling actin filament dynamics in nonmuscle cells. Annu Rev Biophys Biomol Struct, 2000. 29: p. 545-76.

2. Siripala, A.D. and M.D. Welch, SnapShot: actin regulators I. Cell, 2007. 128(3): p. 626.

3. Siripala, A.D. and M.D. Welch, SnapShot: actin regulators II. Cell, 2007. 128(5): p. 1014.

4. Pollard, T.D. and G.G. Borisy, Cellular motility driven by assembly and disassembly of actin filaments. Cell, 2003. 112(4): p. 453-65.

5. Dominguez, R., Structural insights into de novo actin polymerization. Curr Opin Struct Biol, 2010. 20(2): p. 217-25.

6. Renault, L., B. Bugyi, and M.F. Carlier, Spire and Cordon-bleu: multifunctional regulators of actin dynamics. Trends Cell Biol, 2008. 18(10): p. 494-504.

7. Pollard, T.D. and J.A. Cooper, Actin, a central player in cell shape and movement. Science, 2009. 326(5957): p. 1208-12.

8. Dominguez, R., The WH2 Domain and Actin Nucleation: Necessary but Insufficient. Trends Biochem Sci, 2016. 41(6): p. 478-490.

9. Chesarone, M.A. and B.L. Goode, Actin nucleation and elongation factors: mechanisms and interplay. Curr Opin Cell Biol, 2009. 21(1): p. 28-37.

10. Mullins, R.D., W.F. Stafford, and T.D. Pollard, Structure, subunit topology, and actinbinding activity of the Arp2/3 complex from Acanthamoeba. J Cell Biol, 1997. 136(2): p. 331-43.

11. Welch, M.D., A. Iwamatsu, and T.J. Mitchison, Actin polymerization is induced by Arp2/3 protein complex at the surface of Listeria monocytogenes. Nature, 1997. 385(6613): p. 265-9.

12. Rotty, J.D., C. Wu, and J.E. Bear, New insights into the regulation and cellular functions of the ARP2/3 complex. Nat Rev Mol Cell Biol, 2013. 14(1): p. 7-12.

13. Mullins, R.D., J.A. Heuser, and T.D. Pollard, The interaction of Arp2/3 complex with actin: nucleation, high affinity pointed end capping, and formation of branching networks of filaments. Proc Natl Acad Sci U S A, 1998. 95(11): p. 6181-6. 
14. Padrick, S.B., et al., Arp $2 / 3$ complex is bound and activated by two WASP proteins. Proc Natl Acad Sci U S A, 2011. 108(33): p. E472-9.

15. Ti, S.C., et al., Structural and biochemical characterization of two binding sites for nucleation-promoting factor WASp-VCA on Arp2/3 complex. Proc Natl Acad Sci U S A, 2011. 108(33): p. E463-71.

16. Boczkowska, M., et al., Structural analysis of the transitional state of Arp $2 / 3$ complex activation by two actin-bound WCAs. Nat Commun, 2014. 5: p. 3308.

17. Helgeson, L.A., et al., Interactions with actin monomers, actin filaments, and Arp $2 / 3$ complex define the roles of WASP family proteins and cortactin in coordinately regulating branched actin networks. J Biol Chem, 2014. 289(42): p. 28856-69.

18. Campellone, K.G. and M.D. Welch, A nucleator arms race: cellular control of actin assembly. Nat Rev Mol Cell Biol, 2010. 11(4): p. 237-51.

19. Pollard, T.D., Regulation of actin filament assembly by Arp $2 / 3$ complex and formins. Annu Rev Biophys Biomol Struct, 2007. 36: p. 451-77.

20. Quinlan, M.E., et al., Drosophila Spire is an actin nucleation factor. Nature, 2005. 433(7024): p. 382-8.

21. Rebowski, G., et al., X-ray scattering study of actin polymerization nuclei assembled by tandem W domains. Proc Natl Acad Sci U S A, 2008. 105(31): p. 10785-90.

22. Rosales-Nieves, A.E., et al., Coordination of microtubule and microfilament dynamics by Drosophila Rho1, Spire and Cappuccino. Nat Cell Biol, 2006. 8(4): p. 367-76.

23. Quinlan, M.E., et al., Regulatory interactions between two actin nucleators, Spire and Cappuccino. J Cell Biol, 2007. 179(1): p. 117-28.

24. Vizcarra, C.L., et al., Structure and function of the interacting domains of Spire and Fmn-family formins. Proc Natl Acad Sci U S A, 2011. 108(29): p. 11884-9.

25. Zeth, K., et al., Molecular basis of actin nucleation factor cooperativity: crystal structure of the Spir-1 kinase non-catalytic C-lobe domain (KIND)*formin-2 formin SPIR interaction motif (FSI) complex. J Biol Chem, 2011. 286(35): p. 30732-9.

26. Dietrich, S., et al., Structural and functional insights into the Spir/formin actin nucleator complex. Biol Chem, 2013. 394(12): p. 1649-60.

27. Carroll, E.A., et al., Cordon-bleu is a conserved gene involved in neural tube formation. Dev Biol, 2003. 262(1): p. 16-31. 
28. Tam, V.C., et al., A type III secretion system in Vibrio cholerae translocates a formin/spire hybrid-like actin nucleator to promote intestinal colonization. Cell Host Microbe, 2007. 1(2): p. 95-107.

29. Schwintzer, L., et al., The functions of the actin nucleator Cobl in cellular morphogenesis critically depend on syndapin I. EMBO J, 2011. 30(15): p. 3147-59.

30. Ravanelli, A.M. and J. Klingensmith, The actin nucleator Cordon-bleu is required for development of motile cilia in zebrafish. Dev Biol, 2011. 350(1): p. 101-11.

31. Schuler, S., et al., Ciliated sensory hair cell formation and function require the F-BAR protein syndapin I and the WH2 domain-based actin nucleator Cobl. J Cell Sci, 2013. 126(Pt 1): p. 196-208.

32. Grega-Larson, N.E., et al., Cordon bleu promotes the assembly of brush border microvilli. Mol Biol Cell, 2015. 26(21): p. 3803-15.

33. Wayt, J. and A. Bretscher, Cordon Bleu serves as a platform at the basal region of microvilli, where it regulates microvillar length through its WH2 domains. Mol Biol Cell, 2014. 25(18): p. 2817-27.

34. Ahuja, R., et al., Cordon-bleu is an actin nucleation factor and controls neuronal morphology. Cell, 2007. 131(2): p. 337-50.

35. Husson, C., et al., Cordon-Bleu uses WH2 domains as multifunctional dynamizers of actin filament assembly. Mol Cell, 2011. 43(3): p. 464-77.

36. Haag, N., et al., The actin nucleator Cobl is crucial for Purkinje cell development and works in close conjunction with the F-actin binding protein Abp1. J Neurosci, 2012. 32(49): p. 17842-56.

37. Chereau, D., et al., Leiomodin is an actin filament nucleator in muscle cells. Science, 2008. 320(5873): p. 239-43.

38. Skwarek-Maruszewska, A., et al., Different localizations and cellular behaviors of leiomodin and tropomodulin in mature cardiomyocyte sarcomeres. Mol Biol Cell, 2010. 21(19): p. 3352-61.

39. Boczkowska, M., et al., How Leiomodin and Tropomodulin use a common fold for different actin assembly functions. Nat Commun, 2015. 6: p. 8314.

40. Woychik, R.P., et al., 'Formins': proteins deduced from the alternative transcripts of the limb deformity gene. Nature, 1990. 346(6287): p. 850-3. 
41. Zuniga, A., et al., Mouse limb deformity mutations disrupt a global control region within the large regulatory landscape required for Gremlin expression. Genes Dev, 2004. 18(13): p. 1553-64.

42. Breitsprecher, D. and B.L. Goode, Formins at a glance. J Cell Sci, 2013. 126(Pt 1): p. $1-7$.

43. Schonichen, A. and M. Geyer, Fifteen formins for an actin filament: a molecular view on the regulation of human formins. Biochim Biophys Acta, 2010. 1803(2): p. 152-63.

44. Chesarone, M.A., A.G. DuPage, and B.L. Goode, Unleashing formins to remodel the actin and microtubule cytoskeletons. Nat Rev Mol Cell Biol, 2010. 11(1): p. 62-74.

45. Higgs, H.N. and K.J. Peterson, Phylogenetic analysis of the formin homology 2 domain. Mol Biol Cell, 2005. 16(1): p. 1-13.

46. Rivero, F., et al., A comparative sequence analysis reveals a common GBD/FH3-FH1FH2-DAD architecture in formins from Dictyostelium, fungi and metazoa. BMC Genomics, 2005. 6: p. 28.

47. Watanabe, N., et al., p140mDia, a mammalian homolog of Drosophila diaphanous, is a target protein for Rho small GTPase and is a ligand for profilin. EMBO J, 1997. 16(11): p. 3044-56.

48. Chang, F., Movement of a cytokinesis factor cdc12p to the site of cell division. Curr Biol, 1999. 9(15): p. 849-52.

49. Evangelista, M., et al., Bni1p, a yeast formin linking cdc42p and the actin cytoskeleton during polarized morphogenesis. Science, 1997. 276(5309): p. 118-22.

50. Imamura, H., et al., Bni1p and Bnr1p: downstream targets of the Rho family small Gproteins which interact with profilin and regulate actin cytoskeleton in Saccharomyces cerevisiae. EMBO J, 1997. 16(10): p. 2745-55.

51. Chan, D.C., M.T. Bedford, and P. Leder, Formin binding proteins bear WWP/WW domains that bind proline-rich peptides and functionally resemble SH3 domains. EMBO J, 1996. 15(5): p. 1045-54.

52. Kamei, T., et al., Interaction of Bnrlp with a novel Src homology 3 domain-containing Hof1p. Implication in cytokinesis in Saccharomyces cerevisiae. J Biol Chem, 1998. 273(43): p. 28341-5.

53. Tominaga, T., et al., Diaphanous-related formins bridge Rho GTPase and Src tyrosine kinase signaling. Mol Cell, 2000. 5(1): p. 13-25. 
54. Uetz, P., et al., Molecular interaction between limb deformity proteins (formins) and Src family kinases. J Biol Chem, 1996. 271(52): p. 33525-30.

55. Pruyne, D., et al., Role of formins in actin assembly: nucleation and barbed-end association. Science, 2002. 297(5581): p. 612-5.

56. Sagot, I., et al., An actin nucleation mechanism mediated by Bni1 and profilin. Nat Cell Biol, 2002. 4(8): p. 626-31.

57. Pring, M., et al., Mechanism of formin-induced nucleation of actin filaments. Biochemistry, 2003. 42(2): p. 486-96.

58. Otomo, T., et al., Structural basis of actin filament nucleation and processive capping by a formin homology 2 domain. Nature, 2005. 433(7025): p. 488-94.

59. Shimada, A., et al., The core $\mathrm{FH} 2$ domain of diaphanous-related formins is an elongated actin binding protein that inhibits polymerization. Mol Cell, 2004. 13(4): p. 511-22.

60. $\mathrm{Xu}, \mathrm{Y}$., et al., Crystal structures of a Formin Homology-2 domain reveal a tethered dimer architecture. Cell, 2004. 116(5): p. 711-23.

61. Moseley, J.B., et al., A conserved mechanism for Bni1- and mDia1-induced actin assembly and dual regulation of Bni1 by Bud6 and profilin. Mol Biol Cell, 2004. 15(2): p. 896-907.

62. Alberts, A.S., Identification of a carboxyl-terminal diaphanous-related formin homology protein autoregulatory domain. J Biol Chem, 2001. 276(4): p. 2824-30.

63. Li, F. and H.N. Higgs, The mouse Formin mDia1 is a potent actin nucleation factor regulated by autoinhibition. Curr Biol, 2003. 13(15): p. 1335-40.

64. Otomo, T., et al., Structural basis of Rho GTPase-mediated activation of the formin mDia1. Mol Cell, 2005. 18(3): p. 273-81.

65. Rose, R., et al., Structural and mechanistic insights into the interaction between Rho and mammalian Dia. Nature, 2005. 435(7041): p. 513-8.

66. Otomo, T., et al., Crystal structure of the Formin mDia1 in autoinhibited conformation. PLoS One, 2010. 5(9).

67. Nezami, A., et al., Crystal structure of a complex between amino and carboxy terminal fragments of mDia1: insights into autoinhibition of diaphanous-related formins. PLoS One, 2010. 5(9).

68. Maiti, S., et al., Structure and activity of full-length formin mDia1. Cytoskeleton (Hoboken), 2012. 69(6): p. 393-405. 
69. Goode, B.L. and M.J. Eck, Mechanism and function of formins in the control of actin assembly. Annu Rev Biochem, 2007. 76: p. 593-627.

70. Gould, C.J., et al., The formin DAD domain plays dual roles in autoinhibition and actin nucleation. Curr Biol, 2011. 21(5): p. 384-90.

71. Vizcarra, C.L., B. Bor, and M.E. Quinlan, The role of formin tails in actin nucleation, processive elongation, and filament bundling. J Biol Chem, 2014. 289(44): p. 3060213.

72. Vig, A.T., et al., The activities of the C-terminal regions of the formin protein disheveled-associated activator of morphogenesis (DAAM) in actin dynamics. J Biol Chem, 2017. 292(33): p. 13566-13583.

73. Downing, K.H. and E. Nogales, Tubulin and microtubule structure. Curr Opin Cell Biol, 1998. 10(1): p. 16-22.

74. Downing, K.H. and E. Nogales, New insights into microtubule structure and function from the atomic model of tubulin. Eur Biophys J, 1998. 27(5): p. 431-6.

75. Nogales, E., S.G. Wolf, and K.H. Downing, Structure of the alpha beta tubulin dimer by electron crystallography. Nature, 1998. 391(6663): p. 199-203.

76. Nogales, E., et al., High-resolution model of the microtubule. Cell, 1999. 96(1): p. 7988 .

77. Mitchison, T. and M. Kirschner, Dynamic instability of microtubule growth. Nature, 1984. 312(5991): p. 237-42.

78. Desai, A. and T.J. Mitchison, Microtubule polymerization dynamics. Annu Rev Cell Dev Biol, 1997. 13: p. 83-117.

79. Nogales, E. and H.W. Wang, Structural mechanisms underlying nucleotide-dependent self-assembly of tubulin and its relatives. Curr Opin Struct Biol, 2006. 16(2): p. 221-9.

80. Oakley, B.R., et al., Gamma-tubulin is a component of the spindle pole body that is essential for microtubule function in Aspergillus nidulans. Cell, 1990. 61(7): p. 1289301.

81. Zheng, Y., M.K. Jung, and B.R. Oakley, Gamma-tubulin is present in Drosophila melanogaster and Homo sapiens and is associated with the centrosome. Cell, 1991. 65(5): p. 817-23.

82. Stearns, T., L. Evans, and M. Kirschner, Gamma-tubulin is a highly conserved component of the centrosome. Cell, 1991. 65(5): p. 825-36. 
83. Nogales, E., Structural insights into microtubule function. Annu Rev Biochem, 2000. 69: p. 277-302.

84. Luduena, R.F., Multiple forms of tubulin: different gene products and covalent modifications. Int Rev Cytol, 1998. 178: p. 207-75.

85. Baas, P.W., et al., Stability properties of neuronal microtubules. Cytoskeleton (Hoboken), 2016. 73(9): p. 442-60.

86. Wloga, D. and J. Gaertig, Post-translational modifications of microtubules. J Cell Sci, 2010. 123(Pt 20): p. 3447-55.

87. Song, Y. and S.T. Brady, Post-translational modifications of tubulin: pathways to functional diversity of microtubules. Trends Cell Biol, 2015. 25(3): p. 125-36.

88. Kollman, J.M., et al., Microtubule nucleation by gamma-tubulin complexes. Nat Rev Mol Cell Biol, 2011. 12(11): p. 709-21.

89. Bettencourt-Dias, M. and D.M. Glover, Centrosome biogenesis and function: centrosomics brings new understanding. Nat Rev Mol Cell Biol, 2007. 8(6): p. 451-63.

90. Basto, R., et al., Flies without centrioles. Cell, 2006. 125(7): p. 1375-86.

91. Nguyen, M.M., M.C. Stone, and M.M. Rolls, Microtubules are organized independently of the centrosome in Drosophila neurons. Neural Dev, 2011. 6: p. 38.

92. Kuijpers, M. and C.C. Hoogenraad, Centrosomes, microtubules and neuronal development. Mol Cell Neurosci, 2011. 48(4): p. 349-58.

93. Burbank, K.S. and T.J. Mitchison, Microtubule dynamic instability. Curr Biol, 2006. 16(14): p. R516-7.

94. Gundersen, G.G., E.R. Gomes, and Y. Wen, Cortical control of microtubule stability and polarization. Curr Opin Cell Biol, 2004. 16(1): p. 106-12.

95. Conde, C. and A. Caceres, Microtubule assembly, organization and dynamics in axons and dendrites. Nat Rev Neurosci, 2009. 10(5): p. 319-32.

96. Akhmanova, A. and M.O. Steinmetz, Microtubule +TIPs at a glance. J Cell Sci, 2010. 123(Pt 20): p. 3415-9.

97. Akhmanova, A. and M.O. Steinmetz, Tracking the ends: a dynamic protein network controls the fate of microtubule tips. Nat Rev Mol Cell Biol, 2008. 9(4): p. 309-22.

98. Korenbaum, E. and F. Rivero, Calponin homology domains at a glance. J Cell Sci, 2002. 115(Pt 18): p. 3543-5. 
99. Zimniak, T., et al., Phosphoregulation of the budding yeast EB1 homologue Bim1p by Aurora/Ipl1p. J Cell Biol, 2009. 186(3): p. 379-91.

100. Komarova, Y., et al., EB1 and EB3 control CLIP dissociation from the ends of growing microtubules. Mol Biol Cell, 2005. 16(11): p. 5334-45.

101. Miller, R.K., et al., The CLIP-170 orthologue Bik1p and positioning the mitotic spindle in yeast. Curr Top Dev Biol, 2006. 76: p. 49-87.

102. Honnappa, S., et al., Key interaction modes of dynamic +TIP networks. Mol Cell, 2006. 23(5): p. 663-71.

103. Weisbrich, A., et al., Structure-function relationship of CAP-Gly domains. Nat Struct Mol Biol, 2007. 14(10): p. 959-67.

104. Gupta, K.K., et al., Minimal plus-end tracking unit of the cytoplasmic linker protein CLIP-170. J Biol Chem, 2009. 284(11): p. 6735-42.

105. Honnappa, S., et al., An EB1-binding motif acts as a microtubule tip localization signal. Cell, 2009. 138(2): p. 366-76.

106. Fong, K.W., et al., Interaction of CDK5RAP2 with EB1 to track growing microtubule tips and to regulate microtubule dynamics. Mol Biol Cell, 2009. 20(16): p. 3660-70.

107. Al-Bassam, J., et al., Stu2p binds tubulin and undergoes an open-to-closed conformational change. J Cell Biol, 2006. 172(7): p. 1009-22.

108. Mimori-Kiyosue, Y., et al., CLASP1 and CLASP2 bind to EB1 and regulate microtubule plus-end dynamics at the cell cortex. J Cell Biol, 2005. 168(1): p. 141-53.

109. Wu, X., X. Xiang, and J.A. Hammer, 3rd, Motor proteins at the microtubule plus-end. Trends Cell Biol, 2006. 16(3): p. 135-43.

110. Bieling, P., et al., Reconstitution of a microtubule plus-end tracking system in vitro. Nature, 2007. 450(7172): p. 1100-5.

111. Bieling, P., et al., CLIP-170 tracks growing microtubule ends by dynamically recognizing composite EB1/tubulin-binding sites. J Cell Biol, 2008. 183(7): p. 1223-33.

112. Brouhard, G.J., et al., XMAP215 is a processive microtubule polymerase. Cell, 2008. 132(1): p. 79-88.

113. Kline-Smith, S.L. and C.E. Walczak, The microtubule-destabilizing kinesin XKCM1 regulates microtubule dynamic instability in cells. Mol Biol Cell, 2002. 13(8): p. 271831. 
114. Komarova, Y.A., et al., Cytoplasmic linker proteins promote microtubule rescue in vivo. J Cell Biol, 2002. 159(4): p. 589-99.

115. Lansbergen, G., et al., CLASPs attach microtubule plus ends to the cell cortex through a complex with LL5beta. Dev Cell, 2006. 11(1): p. 21-32.

116. Maiato, H., P. Sampaio, and C.E. Sunkel, Microtubule-associated proteins and their essential roles during mitosis. Int Rev Cytol, 2004. 241: p. 53-153.

117. Pacheco, A. and G. Gallo, Actin filament-microtubule interactions in axon initiation and branching. Brain Res Bull, 2016. 126(Pt 3): p. 300-310.

118. Dehmelt, L. and S. Halpain, The MAP2/Tau family of microtubule-associated proteins. Genome Biol, 2005. 6(1): p. 204.

119. Halpain, S. and L. Dehmelt, The MAP1 family of microtubule-associated proteins. Genome Biol, 2006. 7(6): p. 224.

120. Qiang, L., et al., Tau protects microtubules in the axon from severing by katanin. J Neurosci, 2006. 26(12): p. 3120-9.

121. Gong, C.X. and K. Iqbal, Hyperphosphorylation of microtubule-associated protein tau: a promising therapeutic target for Alzheimer disease. Curr Med Chem, 2008. 15(23): p. 2321-8.

122. Roos, J., et al., Drosophila Futsch regulates synaptic microtubule organization and is necessary for synaptic growth. Neuron, 2000. 26(2): p. 371-82.

123. Hummel, T., et al., Drosophila Futsch/22C10 is a MAP1B-like protein required for dendritic and axonal development. Neuron, 2000. 26(2): p. 357-70.

124. Bartolini, F. and G.G. Gundersen, Formins and microtubules. Biochim Biophys Acta, 2010. 1803(2): p. 164-73.

125. Palazzo, A.F., et al., mDia mediates Rho-regulated formation and orientation of stable microtubules. Nat Cell Biol, 2001. 3(8): p. 723-9.

126. Zhou, F., P. Leder, and S.S. Martin, Formin-1 protein associates with microtubules through a peptide domain encoded by exon-2. Exp Cell Res, 2006. 312(7): p. 1119-26.

127. Bartolini, F., et al., The formin mDia2 stabilizes microtubules independently of its actin nucleation activity. J Cell Biol, 2008. 181(3): p. 523-36.

128. Young, K.G., et al., INF1 is a novel microtubule-associated formin. Mol Biol Cell, 2008. 19(12): p. 5168-80. 
129. Szikora, S., et al., The formin DAAM is required for coordination of the actin and microtubule cytoskeleton in axonal growth cones. J Cell Sci, 2017. 130(15): p. 25062519.

130. Daou, P., et al., Essential and nonredundant roles for Diaphanous formins in cortical microtubule capture and directed cell migration. Mol Biol Cell, 2014. 25(5): p. 658-68.

131. Gaillard, J., et al., Differential interactions of the formins INF2, mDia1, and mDia2 with microtubules. Mol Biol Cell, 2011. 22(23): p. 4575-87.

132. Feierbach, B., F. Verde, and F. Chang, Regulation of a formin complex by the microtubule plus end protein tea1p. J Cell Biol, 2004. 165(5): p. 697-707.

133. Wen, Y., et al., EB1 and APC bind to mDia to stabilize microtubules downstream of Rho and promote cell migration. Nat Cell Biol, 2004. 6(9): p. 820-30.

134. Cheng, L., et al., Aurora B regulates formin mDia3 in achieving metaphase chromosome alignment. Dev Cell, 2011. 20(3): p. 342-52.

135. Lewkowicz, E., et al., The microtubule-binding protein CLIP-170 coordinates mDia1 and actin reorganization during CR3-mediated phagocytosis. J Cell Biol, 2008. 183(7): p. 1287-98.

136. Habas, R., Y. Kato, and X. He, Wnt/Frizzled activation of Rho regulates vertebrate gastrulation and requires a novel Formin homology protein Daam1. Cell, 2001. 107(7): p. 843-54.

137. Kim, G.H. and J.K. Han, Essential role for beta-arrestin 2 in the regulation of Xenopus convergent extension movements. EMBO J, 2007. 26(10): p. 2513-26.

138. Liu, W., et al., Mechanism of activation of the Formin protein Daam1. Proc Natl Acad Sci U S A, 2008. 105(1): p. 210-5.

139. Kida, Y.S., et al., Daam1 regulates the endocytosis of EphB during the convergent extension of the zebrafish notochord. Proc Natl Acad Sci U S A, 2007. 104(16): p. 670813.

140. Sato, A., et al., Profilin is an effector for Daam1 in non-canonical Wnt signaling and is required for vertebrate gastrulation. Development, 2006. 133(21): p. 4219-31.

141. Higashi, T., et al., Biochemical characterization of the Rho GTPase-regulated actin assembly by diaphanous-related formins, mDia1 and Daam1, in platelets. J Biol Chem, 2008. 283(13): p. 8746-55.

142. Li, D., et al., Dishevelled-associated activator of morphogenesis 1 (Daam1) is required for heart morphogenesis. Development, 2011. 138(2): p. 303-15. 
143. Nakaya, M.A., et al., Identification and comparative expression analyses of Daam genes in mouse and Xenopus. Gene Expr Patterns, 2004. 5(1): p. 97-105.

144. Lee, H.K. and B. Deneen, Daam2 is required for dorsal patterning via modulation of canonical Wnt signaling in the developing spinal cord. Dev Cell, 2012. 22(1): p. 18396.

145. Wallingford, J.B. and R. Habas, The developmental biology of Dishevelled: an enigmatic protein governing cell fate and cell polarity. Development, 2005. 132(20): p. 4421-36.

146. Menon, K.P., R.A. Carrillo, and K. Zinn, Development and plasticity of the Drosophila larval neuromuscular junction. Wiley Interdiscip Rev Dev Biol, 2013. 2(5): p. 647-70.

147. Jan, L.Y. and Y.N. Jan, Properties of the larval neuromuscular junction in Drosophila melanogaster. J Physiol, 1976. 262(1): p. 189-214.

148. Jan, Y.N. and L.Y. Jan, Genetic dissection of short-term and long-term facilitation at the Drosophila neuromuscular junction. Proc Natl Acad Sci U S A, 1978. 75(1): p. 5159.

149. Ganetzky, B. and C.F. Wu, Neurogenetic analysis of potassium currents in Drosophila: synergistic effects on neuromuscular transmission in double mutants. J Neurogenet, 1983. 1(1): p. 17-28.

150. Johansen, J., et al., Stereotypic morphology of glutamatergic synapses on identified muscle cells of Drosophila larvae. J Neurosci, 1989. 9(2): p. 710-25.

151. Budnik, V., Synapse maturation and structural plasticity at Drosophila neuromuscular junctions. Curr Opin Neurobiol, 1996. 6(6): p. 858-67.

152. Chiba, A. and H. Keshishian, Neuronal pathfinding and recognition: roles of cell adhesion molecules. Dev Biol, 1996. 180(2): p. 424-32.

153. Keshishian, H., et al., The drosophila neuromuscular junction: a model system for studying synaptic development and function. Annu Rev Neurosci, 1996. 19: p. 545-75.

154. Harris, K.P. and J.T. Littleton, Transmission, Development, and Plasticity of Synapses. Genetics, 2015. 201(2): p. 345-75.

155. Landgraf, M. and S. Thor, Development and structure of motoneurons. Int Rev Neurobiol, 2006. 75: p. 33-53.

156. Kohsaka, H., et al., Development of larval motor circuits in Drosophila. Dev Growth Differ, 2012. 54(3): p. 408-19. 
157. Long, J.B. and D. Van Vactor, Embryonic and larval neural connectivity: progressive changes in synapse form and function at the neuromuscular junction mediated by cytoskeletal regulation. Wiley Interdiscip Rev Dev Biol, 2013. 2(6): p. 747-65.

158. Landgraf, M., et al., Embryonic origins of a motor system: motor dendrites form a myotopic map in Drosophila. PLoS Biol, 2003. 1(2): p. E41.

159. Banovic, D., et al., Drosophila neuroligin 1 promotes growth and postsynaptic differentiation at glutamatergic neuromuscular junctions. Neuron, 2010. 66(5): p. 72438.

160. Landgraf, M., et al., even-skipped determines the dorsal growth of motor axons in Drosophila. Neuron, 1999. 22(1): p. 43-52.

161. Ritzenthaler, S., E. Suzuki, and A. Chiba, Postsynaptic filopodia in muscle cells interact with innervating motoneuron axons. Nat Neurosci, 2000. 3(10): p. 1012-7.

162. Kohsaka, H. and A. Nose, Target recognition at the tips of postsynaptic filopodia: accumulation and function of Capricious. Development, 2009. 136(7): p. 1127-35.

163. Li, J., et al., Crucial role of Drosophila neurexin in proper active zone apposition to postsynaptic densities, synaptic growth, and synaptic transmission. Neuron, 2007. 55(5): p. 741-55.

164. Broadie, K. and M. Bate, Innervation directs receptor synthesis and localization in Drosophila embryo synaptogenesis. Nature, 1993. 361(6410): p. 350-3.

165. Chen, K. and D.E. Featherstone, Discs-large (DLG) is clustered by presynaptic innervation and regulates postsynaptic glutamate receptor subunit composition in Drosophila. BMC Biol, 2005. 3: p. 1.

166. Atwood, H.L., C.K. Govind, and C.F. Wu, Differential ultrastructure of synaptic terminals on ventral longitudinal abdominal muscles in Drosophila larvae. J Neurobiol, 1993. 24(8): p. 1008-24.

167. Schuster, C.M., et al., Genetic dissection of structural and functional components of synaptic plasticity. I. Fasciclin II controls synaptic stabilization and growth. Neuron, 1996. 17(4): p. 641-54.

168. Liu, Z., et al., Distinct presynaptic and postsynaptic dismantling processes of Drosophila neuromuscular junctions during metamorphosis. J Neurosci, 2010. 30(35): p. 11624-34.

169. Zito, K., et al., Watching a synapse grow: noninvasive confocal imaging of synaptic growth in Drosophila. Neuron, 1999. 22(4): p. 719-29. 
170. Ruiz-Canada, C. and V. Budnik, Introduction on the use of the Drosophila embryonic/larval neuromuscular junction as a model system to study synapse development and function, and a brief summary of pathfinding and target recognition. Int Rev Neurobiol, 2006. 75: p. 1-31.

171. Budnik, V., et al., Regulation of synapse structure and function by the Drosophila tumor suppressor gene dlg. Neuron, 1996. 17(4): p. 627-40.

172. Sigrist, S.J., et al., Postsynaptic translation affects the efficacy and morphology of neuromuscular junctions. Nature, 2000. 405(6790): p. 1062-5.

173. Featherstone, D.E., et al., Drosophila alpha- and beta-spectrin mutations disrupt presynaptic neurotransmitter release. J Neurosci, 2001. 21(12): p. 4215-24.

174. Pielage, J., R.D. Fetter, and G.W. Davis, Presynaptic spectrin is essential for synapse stabilization. Curr Biol, 2005. 15(10): p. 918-28.

175. Ruiz-Canada, C., et al., New synaptic bouton formation is disrupted by misregulation of microtubule stability in aPKC mutants. Neuron, 2004. 42(4): p. 567-80.

176. Goellner, B. and H. Aberle, The synaptic cytoskeleton in development and disease. Dev Neurobiol, 2012. 72(1): p. 111-25.

177. Sudhof, T.C., The presynaptic active zone. Neuron, 2012. 75(1): p. 11-25.

178. Owald, D. and S.J. Sigrist, Assembling the presynaptic active zone. Curr Opin Neurobiol, 2009. 19(3): p. 311-8.

179. Wichmann, C. and S.J. Sigrist, The active zone T-bar--a plasticity module? J Neurogenet, 2010. 24(3): p. 133-45.

180. Sigrist, S.J. and D. Schmitz, Structural and functional plasticity of the cytoplasmic active zone. Curr Opin Neurobiol, 2011. 21(1): p. 144-50.

181. Ohtsuka, T., CAST: functional scaffold for the integrity of the presynaptic active zone. Neurosci Res, 2013. 76(1-2): p. 10-5.

182. Kittel, R.J., et al., Bruchpilot promotes active zone assembly, Ca2+ channel clustering, and vesicle release. Science, 2006. 312(5776): p. 1051-4.

183. Wagh, D.A., et al., Bruchpilot, a protein with homology to ELKS/CAST, is required for structural integrity and function of synaptic active zones in Drosophila. Neuron, 2006. 49(6): p. 833-44.

184. Fouquet, W., et al., Maturation of active zone assembly by Drosophila Bruchpilot. J Cell Biol, 2009. 186(1): p. 129-45. 
185. Matkovic, T., et al., The Bruchpilot cytomatrix determines the size of the readily releasable pool of synaptic vesicles. J Cell Biol, 2013. 202(4): p. 667-83.

186. Kaufmann, N., et al., Drosophila liprin-alpha and the receptor phosphatase Dlar control synapse morphogenesis. Neuron, 2002. 34(1): p. 27-38.

187. Owald, D., et al., A Syd-1 homologue regulates pre- and postsynaptic maturation in Drosophila. J Cell Biol, 2010. 188(4): p. 565-79.

188. Owald, D., et al., Cooperation of Syd-1 with Neurexin synchronizes pre- with postsynaptic assembly. Nat Neurosci, 2012. 15(9): p. 1219-26.

189. Gallo, G., The cytoskeletal and signaling mechanisms of axon collateral branching. Dev Neurobiol, 2011. 71(3): p. 201-20.

190. Meyer, M.P. and S.J. Smith, Evidence from in vivo imaging that synaptogenesis guides the growth and branching of axonal arbors by two distinct mechanisms. J Neurosci, 2006. 26(13): p. 3604-14.

191. Manitt, C., et al., Netrin participates in the development of retinotectal synaptic connectivity by modulating axon arborization and synapse formation in the developing brain. J Neurosci, 2009. 29(36): p. 11065-77.

192. Zhang, W. and D.L. Benson, Stages of synapse development defined by dependence on F-actin. J Neurosci, 2001. 21(14): p. 5169-81.

193. Nelson, J.C., A.K. Stavoe, and D.A. Colon-Ramos, The actin cytoskeleton in presynaptic assembly. Cell Adh Migr, 2013. 7(4): p. 379-87.

194. Spillane, M., et al., Nerve growth factor-induced formation of axonal filopodia and collateral branches involves the intra-axonal synthesis of regulators of the actinnucleating Arp2/3 complex. J Neurosci, 2012. 32(49): p. 17671-89.

195. Dharmalingam, E., et al., F-BAR proteins of the syndapin family shape the plasma membrane and are crucial for neuromorphogenesis. J Neurosci, 2009. 29(42): p. 1331527.

196. Pawson, C., B.A. Eaton, and G.W. Davis, Formin-dependent synaptic growth: evidence that Dlar signals via Diaphanous to modulate synaptic actin and dynamic pioneer microtubules. J Neurosci, 2008. 28(44): p. 11111-23.

197. Koch, N., et al., Terminal axonal arborization and synaptic bouton formation critically rely on abp1 and the arp2/3 complex. PLoS One, 2014. 9(5): p. e97692. 
198. Perkins, E.M., et al., Loss of beta-III spectrin leads to Purkinje cell dysfunction recapitulating the behavior and neuropathology of spinocerebellar ataxia type 5 in humans. J Neurosci, 2010. 30(14): p. 4857-67.

199. Stankewich, M.C., et al., Targeted deletion of betaIII spectrin impairs synaptogenesis and generates ataxic and seizure phenotypes. Proc Natl Acad Sci U S A, 2010. 107(13): p. 6022-7.

200. Gundelfinger, E.D. and A. Fejtova, Molecular organization and plasticity of the cytomatrix at the active zone. Curr Opin Neurobiol, 2012. 22(3): p. 423-30.

201. Sankaranarayanan, S., P.P. Atluri, and T.A. Ryan, Actin has a molecular scaffolding, not propulsive, role in presynaptic function. Nat Neurosci, 2003. 6(2): p. 127-35.

202. Chia, P.H., M.R. Patel, and K. Shen, NAB-1 instructs synapse assembly by linking adhesion molecules and F-actin to active zone proteins. Nat Neurosci, 2012. 15(2): p. 234-42.

203. Coyle, I.P., et al., Nervous wreck, an SH3 adaptor protein that interacts with Wsp, regulates synaptic growth in Drosophila. Neuron, 2004. 41(4): p. 521-34.

204. Waites, C.L., et al., Piccolo regulates the dynamic assembly of presynaptic F-actin. J Neurosci, 2011. 31(40): p. 14250-63.

205. Leal-Ortiz, S., et al., Piccolo modulation of Synapsin1a dynamics regulates synaptic vesicle exocytosis. J Cell Biol, 2008. 181(5): p. 831-46.

206. Wagh, D., et al., Piccolo Directs Activity Dependent F-Actin Assembly from Presynaptic Active Zones via Daam1. PLoS One, 2015. 10(4): p. e0120093.

207. Bellot, A., et al., The structure and function of actin cytoskeleton in mature glutamatergic dendritic spines. Brain Res, 2014. 1573: p. 1-16.

208. Spence, E.F. and S.H. Soderling, Actin Out: Regulation of the Synaptic Cytoskeleton. J Biol Chem, 2015. 290(48): p. 28613-22.

209. Kim, Y., et al., Phosphorylation of WAVE1 regulates actin polymerization and dendritic spine morphology. Nature, 2006. 442(7104): p. 814-7.

210. Soderling, S.H., et al., A WAVE-1 and WRP signaling complex regulates spine density, synaptic plasticity, and memory. J Neurosci, 2007. 27(2): p. 355-65.

211. Hotulainen, P., et al., Defining mechanisms of actin polymerization and depolymerization during dendritic spine morphogenesis. J Cell Biol, 2009. 185(2): p. 323-39. 
212. Chazeau, A., et al., Nanoscale segregation of actin nucleation and elongation factors determines dendritic spine protrusion. EMBO J, 2014. 33(23): p. 2745-64.

213. Miki, H., S. Suetsugu, and T. Takenawa, WAVE, a novel WASP-family protein involved in actin reorganization induced by Rac. EMBO J, 1998. 17(23): p. 6932-41.

214. Lamprecht, R., et al., Fear conditioning drives profilin into amygdala dendritic spines. Nat Neurosci, 2006. 9(4): p. 481-3.

215. Kapitein, L.C. and C.C. Hoogenraad, Building the Neuronal Microtubule Cytoskeleton. Neuron, 2015. 87(3): p. 492-506.

216. Koch, I., et al., Drosophila ankyrin 2 is required for synaptic stability. Neuron, 2008. 58(2): p. 210-22.

217. Pielage, J., et al., A presynaptic giant ankyrin stabilizes the NMJ through regulation of presynaptic microtubules and transsynaptic cell adhesion. Neuron, 2008. 58(2): p. 195209.

218. Stephan, R., et al., Hierarchical microtubule organization controls axon caliber and transport and determines synaptic structure and stability. Dev Cell, 2015. 33(1): p. 521.

219. Koles, K. and V. Budnik, Wnt signaling in neuromuscular junction development. Cold Spring Harb Perspect Biol, 2012. 4(6).

220. Budnik, V. and P.C. Salinas, Wnt signaling during synaptic development and plasticity. Curr Opin Neurobiol, 2011. 21(1): p. 151-9.

221. Gogel, S., et al., The Drosophila microtubule associated protein Futsch is phosphorylated by Shaggy/Zeste-white 3 at an homologous GSK3beta phosphorylation site in MAP1B. Mol Cell Neurosci, 2006. 33(2): p. 188-99.

222. Packard, M., et al., The Drosophila Wnt, wingless, provides an essential signal for preand postsynaptic differentiation. Cell, 2002. 111(3): p. 319-30.

223. Luchtenborg, A.M., et al., Heterotrimeric Go protein links Wnt-Frizzled signaling with ankyrins to regulate the neuronal microtubule cytoskeleton. Development, 2014. 141(17): p. 3399-409.

224. Kaech, S., et al., Cytoskeletal microdifferentiation: a mechanism for organizing morphological plasticity in dendrites. Proc Natl Acad Sci U S A, 2001. 98(13): p. 708692.

225. Gu, J., B.L. Firestein, and J.Q. Zheng, Microtubules in dendritic spine development. J Neurosci, 2008. 28(46): p. 12120-4. 
226. Hu, X., et al., Activity-dependent dynamic microtubule invasion of dendritic spines. J Neurosci, 2008. 28(49): p. 13094-105.

227. Jaworski, J., et al., Dynamic microtubules regulate dendritic spine morphology and synaptic plasticity. Neuron, 2009. 61(1): p. 85-100.

228. Matusek, T., et al., The Drosophila formin DAAM regulates the tracheal cuticle pattern through organizing the actin cytoskeleton. Development, 2006. 133(5): p. 957-66.

229. Harris, E.S., et al., Mechanistic differences in actin bundling activity of two mammalian formins, FRL1 and mDia2. J Biol Chem, 2006. 281(20): p. 14383-92.

230. Lu, J., et al., Structure of the FH2 domain of Daam1: implications for formin regulation of actin assembly. J Mol Biol, 2007. 369(5): p. 1258-69.

231. Gombos, R., et al., The Formin DAAM Functions as Molecular Effector of the Planar Cell Polarity Pathway during Axonal Development in Drosophila. J Neurosci, 2015. 35(28): p. 10154-67.

232. Matusek, T., et al., Formin proteins of the DAAM subfamily play a role during axon growth. J Neurosci, 2008. 28(49): p. 13310-9.

233. Migh, E., et al., Microtubule organization in presynaptic boutons relies on the formin DAAM. Development, 2018. 145(6).

234. Lepicard, S., et al., A presynaptic role of microtubule-associated protein 1/Futsch in Drosophila: regulation of active zone number and neurotransmitter release. J Neurosci, 2014. 34(20): p. 6759-71.

235. Molnar, I., et al., DAAM is required for thin filament formation and Sarcomerogenesis during muscle development in Drosophila. PLoS Genet, 2014. 10(2): p. e1004166.

236. Gratz, S.J., et al., Genome engineering of Drosophila with the CRISPR RNA-guided Cas9 nuclease. Genetics, 2013. 194(4): p. 1029-35. 